\title{
Dialectics of Spontaneity
}

The Aesthetics and Ethics of Su Shi (1037-1101) in Poetry

\author{
By \\ Zhiyi Yang
}

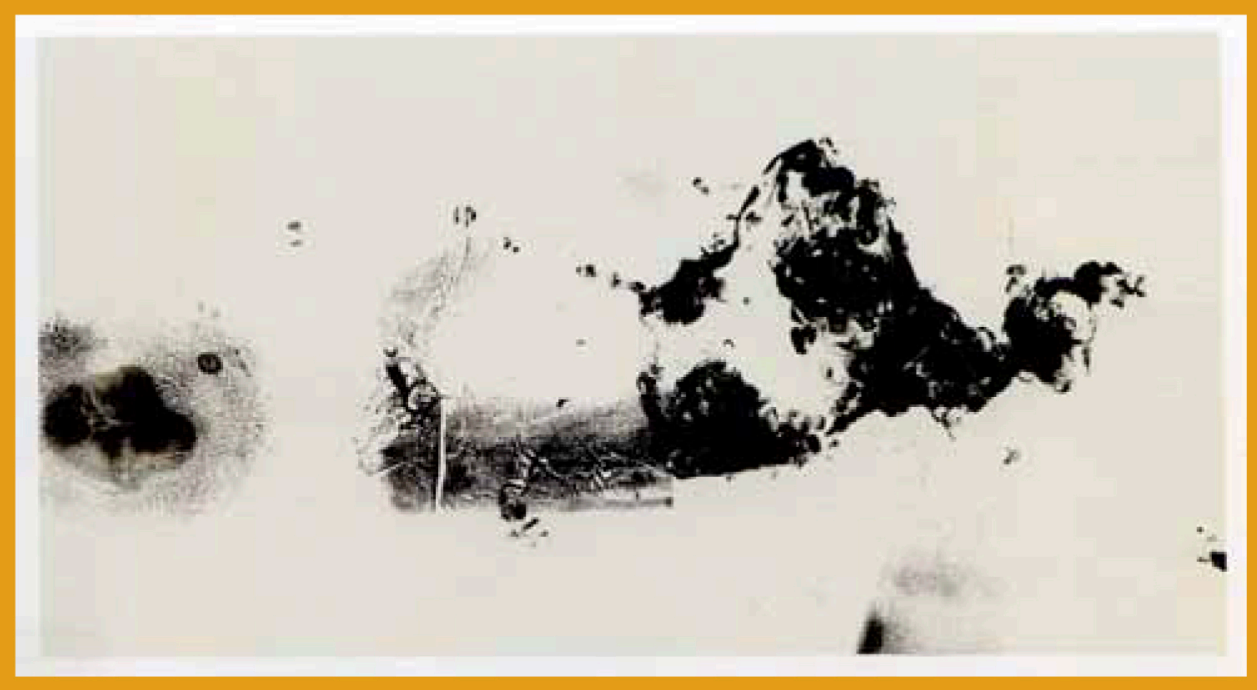

B R I L L 
Dialectics of Spontaneity 


\title{
Sinica Leidensia
}

\author{
Edited by \\ Barend J. ter Haar \\ Maghiel van Crevel \\ In co-operation with \\ P.K. Bol, D.R. Knechtges, E.S. Rawski, \\ W.L. Idema, H.T. Zurndorfer
}

VOLUME 122

The titles published in this series are listed at brill.com/sinl 


\section{Dialectics of Spontaneity}

The Aesthetics and Ethics of Su Shi (1037-1101) in Poetry

By

Zhiyi Yang

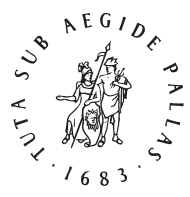

B R I L L

LEIDEN | BOSTON 
Cover illustration: Zhu Lan, "Kiss" (2014).

Library of Congress Cataloging-in-Publication Data

Yang, Zhiyi, 1981-

Dialectics of spontaneity : the aesthetics and ethics of Su Shi (1037-1101) in poetry / by Zhiyi Yang. pages $\mathrm{cm}$. -- (Sinica Leidensia ; Volume 122)

Includes bibliographical references and index.

ISBN 978-90-04-29849-1 (hardback : acid-free paper) -- ISBN 978-90-04-29853-8 (e-book)

1. Su, Shi, 1037-1101--Criticism and interpretation. 2. Spontaneity (Philosophy) in literature. 3. Poetics-History--To 1500. I. Title.

PL2685.Z5Y37 2015

895.11'409--dc23

2015015945

This publication has been typeset in the multilingual "Brill" typeface. With over 5,100 characters covering Latin, IPA, Greek, and Cyrillic, this typeface is especially suitable for use in the humanities.

For more information, please see brill.com/brill-typeface.

ISSN 0169-9563

ISBN 978-90-04-29849-1 (hardback)

ISBN 978-90-04-29853-8 (e-book)

Copyright 2015 by Koninklijke Brill NV, Leiden, The Netherlands.

Koninklijke Brill NV incorporates the imprints Brill, Brill Hes \& De Graaf, Brill Nijhoff, Brill Rodopi and Hotei Publishing.

All rights reserved. No part of this publication may be reproduced, translated, stored in a retrieval system, or transmitted in any form or by any means, electronic, mechanical, photocopying, recording or otherwise, without prior written permission from the publisher.

Authorization to photocopy items for internal or personal use is granted by Koninklijke Brill NV provided that the appropriate fees are paid directly to The Copyright Clearance Center, 222 Rosewood Drive,

Suite 910, Danvers, MA 01923, USA.

Fees are subject to change.

This book is printed on acid-free paper. 
To my parents, Qiulian and Wenhua

$$
\because
$$





\section{Contents}

Acknowledgements IX

Abbreviations XII

\section{Introduction 1}

Art and Spontaneity 2

Su Shi as the 'Spontaneous Artist' 11

Chapter Outline 19

1 The Poet as a Perfect Mirror 23

The Style, the Artist and the Way 25

The Education of the Artist as a Young Monk 34

Monastic Poetry and Its Controversy 40

Poetry as Skilful Means 45

Coda 50

2 The Making of Spontaneity in a Work of Art 54

The Emphasis on Practice 55

Oblivion as a Form of Liberation 61

Lodging in a World of Resemblance 68

Coda 82

3 Eloquent Stones 86

The Aesthetics of Nature and the Usefulness of Uselessness 87

The Lesson from a Grotesque Rock 91

Uselessness of the Useful: the Case of Inkstones 96

Poetry on Exchange: Rocks in Literati Economics 104

Coda $\quad 116$

4 Return to an Inner Utopia 119

Literary Friendship with an Ancient 121

A Metaphorical Landscape 126

A Poetic Ethnography 129

The Poetry of Discontent 137

Peach Blossom Spring as an Inner Utopia 145

Return 155

Coda 161 
5 The Spontaneous Body 164

The Amateur Alchemist before Mt Luofu $\quad 165$

Reading Destiny 172

Discourse on the Dragon and the Tiger ${ }_{176}$

The Daoist on White Crane Peak 187

Retreat from Nature 193

Active Immersion in Transience 198

Coda 201

Towards a Conclusion $\quad 202$

Bibliography 205

Index 225 


\section{Acknowledgements}

The first book, like the first-born, is always special. I owe this book to the many people who have taught, helped and supported me on my journey from China to America, and on to Europe. The shortcomings and mistakes, needless to say, are mine.

The first person I wish to thank is Martin Kern, my advisor at Princeton, where I completed and defended the dissertation that eventually morphed into this present book. A transcontinental humanist himself, he has enriched my project with guidance, insight and - most importantly - an intellectual audacity that encouraged me to explore unknown waters.

Multiple passages and chapters of this book have benefited from the classes and private tutorials at the various academic institutions where I have studied or stayed. I will credit many outstanding scholars for their teaching and advice - more names would be included if I could.

Starting with Peking University, I would first like to thank Chen Yuehong, who nourished my intellectual curiosity and supported my multifaceted investigations; Zhang Ming, who brought me to Song poetry (to Su Shi in particular); Yuan Xingpei, who taught me how to read Tao Qian; Meng Hua, who trained me to meet rigorous academic standards; Zhang Pei, whose interdisciplinary research and intellectual freedom has always inspired me; Zhang Hui, who taught me Plato and the method of reading between the lines; Dai Jinghua, who introduced me to cultural studies; Liu Dong, who opened my eyes to American sinology; and last, but not least, Yue Daiyun, a precursor of Chinese comparative literature, who has encouraged and inspired me to explore further and farther reaches. I thank the stellar rank of my undergraduate teachers, including Niu Ke, Yan Buke, Qian Zhixi, Zhang Fan, Yang Lihua and Zhao Dunhua. For a timid teenager from the province, they established the paragons of scholarship that I look up to. I hope to reach their heights one day.

My teachers at Princeton form another formidable rank. I thank Stephen Teiser for his seminars on Chinese religions, which provided a wealth of sources and inspiration for the last chapters of this book. My reflections on art grew out of Daniel Heller-Rozen's seminar on European aesthetics. Willard Peterson, with his kind bemusement, quashed my youthful conceit and obliged me to reread 'familiar' texts more closely and without bias, a practice that proved extremely fruitful. Under Benjamin Elman's inquisitive gaze, I finished a paper on Zhu Xi. It became my first published English paper, and was also a source from which I drew information about Su Shi's intellectual opponents. Susan Naquin taught me how to write - an art that I am still working to master. The 
seminars of Andrew Plaks, Thomas Hare, Anna M. Shields, Ping Wang and Paize Keulemans have provided me with methodologies and perspectives that I have subsequently applied to my research. I thank David Leheny and Everett Zhang for recruiting me as a novice teacher. Brigid E. Vance and Cameron A. Moore, my classmates at Princeton, devoted their precious time to proofreading my drafts. Chunmei Du, Ya Zuo, Mick Hunter, Scott Gregory, Nick Admussen, Erin Brightwell, Maren Ehlers and many others supported me with their friendship and engaged me in stimulating debates. I thank Martin Heijdra, Chinese bibliographer at the East Asian Library, who so ably assisted me with access to books and databases; Hue Kim Sue, our long-serving department secretary, who treated all graduate students as her children; and Richard Chafey, our program manager, who helped to finance my research trips. I am deeply grateful for the generous support that I received from the East Asian Program, Princeton Graduate School and the Whiting Fellowship which funded my six years of study, summer schools in Japanese and German, conferences and overseas research trips.

The fourth year of my graduate study was spent at Nuremberg-Erlangen University, hosted by the International Consortium Fate Freedom and Prognostication, under the tutelage of Michael Lackner. It was a highly productive year: I travelled extensively and spent many hours talking to Mr. Lackner and other colleagues, yet somehow still managed to write three chapters of my dissertation draft. I cherish the memory of a blue house in the woods by the Europa Canal, and with it the recollections of snow in the winter, the summer breeze, the smell of coffee, and the hazy puffs of smoke from the Professor's second-floor window.

I thank my current colleagues at Goethe University Frankfurt - Iwo Amelung, Dorothea Wippermann, Mirjam Tröster, Clemens Büttner and, our department's secretary, Brunhild Sude - for their support over the last two and half years. Without them I could not have started a new job in a new country, undertaken a new research field on modern classicist poetry, organised a conference, and finished revising the manuscript, all at the same time.

Other scholars who gave me generous support on various stages of my career include David Knechtges, Kang-I Sun Chang, Marian Galik, Paolo Santangelo, Shuen-fu Lin, Haun Saussy, Stephen Owen, Michael Nylan and many others. Their kindness and inspiration are fondly remembered.

I thank the editors of T'oung-Pao for publishing my paper "Return to an Inner Utopia: Su Shi's Transformation of Tao Qian in His Exile Poetry" (TP 99 [2013]: 329-78) and allowing me to include it, with minor changes, as Chapter Four in this book. 
I thank Albert Hoffstädt and Patricia Radder, editors at Brill, Divya Castelino and Noel Castelino, my copy editors, and the anonymous manuscript reviewer, for turning the book from a concept into a reality. I thank the artist Xue Lei for our discussions on modern art; and Zhu Lan, for generously allowing me to use her ink painting "Kiss" (2014) for the cover of the book. It is a masterpiece that illustrates my interpretation of artistic spontaneity as the appearance of naturalness created with the highest technical accomplishment.

I have many friends and family members to thank, without whom I might never have coped over the years and across continents. I will omit their names for privacy's sake, but they know they are in my thoughts. I will only speak of the constant factor in my life: the love of my parents, Qiulian and Wenhua, to whom this book is dedicated. One thing I cannot have remembered, but nevertheless vividly stands out in imagined memory, is the profile of a young father and teacher of literature reciting Tang poems to his barely-babbling infant daughter; and that of a young mother, who tolerated such foolishness. Now, I have written a book - in a language they do not understand. But I know that they will take great pride in my small contribution to the field of Chinese literature. 


\section{Abbreviations}

QTS

QSS

SKQS

SSJZS

SSNP

$s s s J$

ssWJ

T.

TYM

光

$X Q H W$

ZZJS

Quan Tang shi 全唐詩. Beijing: Zhonghua shuju, 1960.

Quan Song shi 全宋詩. Beijing: Peking University Press, 1991.

Yingyin Wenyuange Siku quanshu 景印文淵閣四庫全書. Taipei: Taiwan shangwu yinshuguan, 1983-1986.

Ruan Yuan 阮元. Shisanjing zhushu 十三經注疏. Beijing: Zhonghua shuju, 1980.

Kong Fanli 孔凡禮. Su Shi nianpu 蘇軾年譜. Beijing: Zhonghua shuju, 1991.

Kong Fanli 孔凡禮, editor. Su Shi shiji 蘇軾詩集. Beijing: Zhonghua shuju, 1982.

Kong Fanli 孔凡禮, editor. Su Shi wenji 蘇軾文集. Beijing: Zhonghua shuju, 1986.

Takakusu Junjirō 高楠順次郎, Watanabe Kaigyoku 渡辺海旭 and Ono Gemmyō 小野玄妙, editors. Taishō shinshū daizōkyō 大正新脩大 藏經 (Taishō Tripitaka). Tokyo: Daizō shuppansha, 1924-1932.

Yuan Xingpei 袁行霈. Tao Yuanming jijianzhu 陶淵明集箋注. Beijing: Zhonghua shuju, 2003.

Nishi Giyū 西義雄 and Tamaki Kōshirō 玉城康四郎, editors. Shinsan dainihon soku zōkyō 新纂大日本續藏經. Tokyo: Kokusho kankōkai, 1975-1989.

Lu Qinli 逯欽立. Xianqin Han Wei Jin Nanbeichao shi 先秦漢魏晉南 北朝詩. Beijing: Zhonghua shuju, 1983 .

Guo Qingfan 郭慶藩. Zhuangzi ji shi 莊子集釋. Beijing: Zhonghua shuju, 1961. 


\section{Introduction}

This book tackles the myth of spontaneity. Since the end of the Han, and particularly at the time of the Six Dynasties, Chinese literary criticism increasingly attributed artistic excellence to individual disposition ( $q i$ 氣) or talent (cai 才). ${ }^{1}$ The source of the individual's talent was eventually identified to be the mystical 'Way' (Dao): a vital cosmic force that follows the constant course of self-regeneration. The Chinese notion of genius was born by the pairing of 'talent' to the 'Way'. As the Way is not just a cosmological concept but also an ethical concept, Chinese criticism has, since its beginning, shown strong moralistic propensities. The literature that is perceived as the spontaneous overflow from the nature of a Man of the Way possesses both aesthetic and moral power.

Contrary to the critical discourses that tend to treat 'spontaneity' as a creative entity, I argue that artistic spontaneity can only be defined negatively - as the absolute opposite of convention or intentionality. 'Spontaneous creation' is a dynamic process in which the artist's subjectivity persistently - and vainly rejects itself. As such a rejection is designed to fail, the ideal 'spontaneity' is born retrospectively as an absence. It is, in Žižek's terms, "a withdrawal-from which creates that from which it withdraws". ${ }^{2}$

The subject of my study is Su Shi 蘇軾 (1037-1101). His polite name was Zizhan 子瞻, but he was popularly known by his style name, Dongpo 東坡, or 'East Slope'. 3 Seen, even by his contemporaries, as the greatest genius of his age, Su Shi himself contributed to the myth by describing the process of his creation as becoming one with the Way. At the same time, however, in

1 Including, for instance, Cao Pi’s 曹丕 (187-226) treatise “Lunwen” 論文 in his Dianlun 典論, Lu Ji’s 陸機 (262-303) “Wenfu” 文賦, Zhong Rong's 鐘嶸 (468-518) Shipin 詩品 and Liu Xie's 劉妿 $(465 ?-520)$ Wenxin diaolong 文心雕龍.

2 See Slavoj Žižek, Event: Philosophy in Transit (London: Penguin Books, 2014), 47.Žižek, in turn, is inspired by Hegel's notion absoluter Gegenstoss.

3 Given the accessibility of Su Shi's biography in any academic language, I will not give an account of his life here. His first English biography, The Gay Genius, was written by Lin Yutang and published in 1947. Since then multiple biographies, dissertations, and monographs on Su Shi and translations of his poetry have appeared in the English language. For an account of his life, an interested reader can start with George C. Hatch's long entry "Su Shih" in Sung Biographies (ed. Herbert Franke. Wiesbaden: Franz Steiner Verlag, 1976) and progress eventually to Ronald C. Egan's extensive Word, Image, and Deed in the Life of Su Shi (Cambridge, Mass.: Harvard University Asia Center, 1994). I recently also contributed the entry on Su Shi in Berkshire Dictionary of Chinese Biography (ed. Kerry Brown. Berkshire Publishing, 2014). 
his writing we often find the exhortation to practice in order to achieve true artistic excellence, the longing for the lost oneness with nature, the deliberate emulation of literary precursors, and we also see the pain caused by his simultaneous desire for transcendence and his attachment to the phenomenal world. This book thus treats Su Shi as though he, simultaneously, is and is not a spontaneous genius. He strives to achieve absolute spontaneity akin to the creative process of nature; yet it is something he cannot and must not do, since the moment he becomes nature - were it possible - his creations would be no longer works of art, but pure natural objects, external to the system of meaning.

Such a paradox is most clearly seen in his connoisseur literature on rocks. In these writings, rock, a natural object, is aestheticised to acquire human character and agency, and is appraised like an object of art. Yet it remains absolutely transcendental to all the significations designated onto it by the poet-connoisseur. The signified nature maintains its alienness. He accords the same status of absolute spontaneity to a precursor poet: Tao Qian 陶潛 $\left(35^{2} ?-427\right.$ ? $),{ }^{4}$ a Jin Dynasty recluse whose limpid lyric style was emulated by Su Shi in his exile poetry. His emulation was paradoxical. An exile was held captive by the political system, and the reference to Tao Qian further attests to the cultural forces that shaped his self perception. Yet, through the emulation of Tao Qian, Su exercised imagined power of choice and presented himself as a free agent, disengaging from the institutionalising forces and returning into nature. The same paradox is present in his alchemical literature. His desire to become a transcendent immortal - thus assimilating himself into the natural order of things - is nonetheless often questioned and ultimately abandoned. He chooses instead to reside in constant transience. These paradoxes, together with $\mathrm{Su}$ Shi's acute awareness of them, have spurred my investigation.

\section{Art and Spontaneity}

The legitimacy of applying the terms 'art' and 'spontaneity' to the context of classical China is not self-evident. It therefore begs clarification.

4 There had been many debates on Tao Qian's name and dates. For a summary, see Wendy Swartz, Reading Tao Qian: Shifting Paradigms of Historical Reception (427-1900) (Cambridge, Mass.: Harvard University Asia Center, 2008), 1n1, 5nı. She chooses Tao Yuanming 陶淵明, while I prefer Tao Qian, since the different contexts when Su Shi used 'Tao Qian' and 'Yuanming' suggest that he regarded Qian as the formal name and Yuanming the polite name. The dates of Tao Qian follow Yuan Xingpei 袁行霈, “Tao Yuanming nianpu jianbian” 陶淵明年譜 簡編, TYM , 845-65. For the contention over his dates and its implications, see ch. 4, fn. 33 . 
The word 'spontaneous' is commonly defined as arising or proceeding entirely from natural impulse, without any external stimulus or constraint. (For instance, 'He made a spontaneous decision to go to Lisbon'.) However, this is not how I use it in this book. This book is concerned with artistic spontaneity and will proceed to its similar expression in ethics, which shares the structure of dialectical movement. As argued earlier, absolute spontaneity in art is only theoretically postulated and cannot be actualised. So here "artistic spontaneity" is further perceived as a state of unreflective immediacy that one 'returns' to after having mastered a modular set of skills, actions or ways of thought through a long period of concentrated and mindful practice. (For instance, a prima ballerina's every spontaneous movement embodies formal beauty only because she has been rigorously trained and has internalised the rules of dance so that her movements are instinctive.) It is a dialectical concept that embraces the mediacy of materiality, craft, learning, rule, ritual and tradition.

Unlike scholars who choose to transliterate a Chinese term (e.g., wen, qi, and the like) that corresponds to multiple concepts in the English language, I employ an English term that finds its expression in a cluster of Chinese words. Simply put, 'spontaneity' in this book is not the counterpart of any single Chinese term. It describes a conviction whereby various types of human behaviour and cultural accomplishment can be concrete articulations of the Way, and are therefore expurgated of conscious human agency. A primary Chinese term for this notion is ziran 自然 (literally 'self-so-ness'). Ziran in the premodern context could function as an adjective: 'being natural'; or adverb: 'naturally'; but not as a noun in the modern sense of 'nature', that is, our material environment. The semantic gist of 'spontaneity' is also found in terms such as tianran 天然 ('heavenly made so-ness'), tianjun 天鈞 ('Heaven, the Potter'), tiancai 天才 ('heavenly endowed talent'), shensi 神思 ('divinely inspired thinking'), wuxin 無心 ('mindless'), wuyi 無意 ('without intention'), wuwei 無為 ('without agitation'), and so forth. Conspicuously, these are all compound words that suggest that a certain object is originated from itself $(z i)$, created by a transcendental agent (tian or shen) or, in any case, simply formed without human interference $(w u)$. All these terms further affirm that 'spontaneity' is a negatively constructed concept as the absence of subjectivity in the process of artistic creation.

Therefore, the term 'artistic spontaneity' appears an oxymoron. 'Art'5 derives from the Latin word ars, meaning 'skill, craft'. Etymologically, 'art' suggests

5 Admittedly, 'art' and its derivative terms ('artist', 'artistry', 'artistic', etc.) are not used here in a strictly historical fashion. Yet, if we are strictly historical, we may hardly talk about 'art' at all. Hans Belting argues that the era of art in Europe began abruptly in 1400, when "art took on a different meaning and became acknowledged for its own sake - art as invented by a famous 
something routine, technical and mediated by material - the very opposite of 'spontaneity'. In Greek, art is technee. According to Plato's mimesis theory, an artist is an image-maker who makes something that is not a real thing, but merely an image of a thing. ${ }^{6}$ An artist is a craftsman, and a secondary one. Likewise, the etymology of 'poetry' is poetica in Latin and poesis in Greek. Poein, the verbal form of poesis, means 'to make or compose' - nothing spontaneous is implied about the poetic craft.

Plato, however, also famously attributed the origin of the poetic art to externally induced 'divine inspiration'. In Ion, Socrates declared that poets must be bereft of their senses through direct intervention by the Muses. As instruments of gods, they make poetry without real knowledge of their arts. ${ }^{7}$ In Phaedrus, poets are said to be in a 'divine madness' when possessed by the Muses. ${ }^{8}$ Inspired poets are no longer merely artisans but prophets, divinely free from selfconsciousness in the process of creation.

The contrast between etymology and philosophy suggests a tension between the two ideals of artists. One ideal type, the 'spontaneous artist', is void of self-consciousness or intentionality, propelled by a sheer force of creativity that controls the making of his work. The opposing ideal is the image of the artist as a craftsman, who methodically composes his work after careful design, following rules learned from his training. A survey of comparative aesthetics

artist and defined by a proper theory"; see Hans Belting, Foreword to Likeness and Presence: $a$ History of the Image before the Era of Art, trans. Edmund Jephcott (Chicago: University of Chicago Press, 1990), xxi. Arthur Danto further argues that the era of art ended in the 1980s, when artists and museum curators ceased to care about any a priori criterion as to what that art must look like; see Danto, After the End of Art (Princeton: Princeton University Press, 1997), 4-6. Danto regards the concept of 'art' representing only a certain model of narrative in the life of art practice, which lived before and after the era of art. In this regard, Su Shi lived in a world where there was art practice but not the modern concept of art. Therefore, calling a Song painting 'a work of art' is no less legitimate than calling Laocoon 'a work of art'. For a summary of contemporary debates on the definition of art and a reference list for further reading, see Stephen Davies, "Definitions of art", in The Routledge Companion to Aesthetics, eds. Berys Gaut and Dominic McIver Lopes (New York: Routledge, 2005; 2nd edition; 2007 rp.), 227-39. I thus use these terms not unreflectively but for want of better options. In this book, I put into the category 'art' those works which have aesthetic forms, produced by creative activities, and recognised as 'art' by historical consensus. My category of 'art' includes poetry. Su Shi is called an 'artist' in the strong sense of the term, because he was an acclaimed poet, calligrapher and painter.

6 Plato, Republic, Book X, 595a-b; see The Republic of Plato (1991 rpt.), trans. Allan Bloom (New York: Perseus Books Group, 1968), 277.

7 Plato, "Ion", 534c-e, 541e-542a; see Selected Dialogues of Plato, trans. Benjamin Jowett (New York: Modern Library, 2001), 12, 23-4.

8 Plato, "Phaedrus", 265b-c; see ibid., 173. 
shows this tension to be a universal feature which gives rise to a variety of artistic theories.

From classical to medieval times, European poets frequently invoked the muses or God as the source of their creativity - either with religious piety or as a figure of speech. This rhetoric device reflected the external-induced theory of inspiration. Borges relates the story of Caedmon, a seventh-century educated herdsman who, in a dream, received the command of God to "sing about the origin of created things". He then wrote poems according to this divine instruction and became the first sacred poet of the English nation. ${ }^{9}$ In this extreme case, the poet was turned into an instrument through which God sang. With the rise of Romanticism, theorists began to suggest that the origin of inspiration was not from without, but from within - from individual genius. In his second preface (1802) to Lyrical Ballads, William Wordsworth (1770-1850) proposed that "all good poetry is the spontaneous overflow of powerful feelings". ${ }^{0}$ Samuel Coleridge (1772-1834) later modified Wordsworth's position and distinguished two kinds of poets: those who wrote "by an act of will" and those "by the inspiration of a genial and productive nature". ${ }^{11}$ But it was the second kind that he regarded as having the most original poetic talent. Generally, eighteenth-century Romanticism emphasised the need for spontaneity in thought and action, and in the expression of thought, which resulted from natural genius and the power of imagination. Though later poets and literary critics have mostly rejected their unreserved exaltation of emotional spontaneity, the internal-origin theory finds its modern proponent in psychology and psychoanalysis, where the subconscious or the unconscious is often regarded as the fountain of creativity. Like Coleridge, Freud distinguished two kinds of poets: those who "take over their material ready-made", and those who "seem to create their material spontaneously". It was the second kind that he was interested in: they are the daydreamers whose creativity comes from thwarted desires and memories. ${ }^{12}$

9 Jorge Luis Borges, "The Dream of Coleridge", in Other Inquisitions: 1937-1952, trans. Ruth L.C. Simms (Austin: University of Texas Press, 1964), 15-6.

10 William Wordsworth and Samuel Taylor Coleridge, Lyrical Ballads (New York: Barnes and Noble, 1963), 240.

Samuel Taylor Coleridge, The Major Works (Cambridge, uk: Oxford University Press, 1985), 320.

See Sigmund Freud, "The Relation of the Poet to Day-Dreaming" (1908), in On Creativity and the Unconscious (New York: Harper and Row, 1958), 44-54. C.G. Jung further proposed that the collective unconscious was the origin of 'archetypes' expressed through myths and fairytales; see The Archetypes and the Collective Unconscious (2nd edition), trans. R.F.C. Hull (London: Routledge and Kegan Paul, 1968), 3-5, and passim. The archetype theory was later developed by Northrop Frye into paradigms of literary criticism; see 
The tension between art and spontaneity continues to be an important issue. Indeed, contemporary art often experiments with various expressions of freedom, where artists vie to discard reified forms and techniques and test the flimsy boundary that separates art from nature. ${ }^{13}$ As Adorno (1903-1969) remarked, "art that is simply a thing is an oxymoron. Yet the development of this oxymoron is the inner direction of contemporary art". ${ }^{14}$ Put otherwise, the dialectic nature of art always propels art to move against itself and towards its opposite, non-art. ${ }^{15}$ Seen from a historical perspective, the aesthetic ideal of 'artistic spontaneity' symptomises the revolutionary spirit of art which goes against convention, establishment and institutionalisation. In other words, 'artistic spontaneity' is not the opposite of art, but rather is contained within 'art' as its self-negation, a critical element that is essential to its development.

'Artistic spontaneity' plays the role of a go-between, a medium that negotiates on behalf of 'being' with absolute 'nothingness'. Plato's prophetic poet is not unlike the paradigmatic philosopher Socrates who, in the Symposium, is compared to a daemon (in Greek mythology a messenger between gods and men) - Eros. ${ }^{16}$ According to the prophetess Diotima, Eros is the illegitimate son of Poverty and Resource. He himself is not beautiful, but is a perpetual desirer of beauty - forever hungry, forever chasing. Playing a role similar to that of Eros, aesthetic judgment for Kant (1724-1804) is an intermediate faculty between that of cognition (pure reason) and that of desire (practical reason). ${ }^{17}$ Judgment is "equipped with an a priori principle for the possibility of nature, but only in a subjective respect" - namely, it embodies the principle of autonomy between necessity and freedom. ${ }^{18}$ In the disinterested aesthetic experience, imagination in its freedom accords with understanding in its conformity

Anatomy of Criticism (Princeton: Princeton University Press, 1957), 131-239. The relation between the unconscious and creativity is also the topic of many psychological experiments. Popular reading on this topic includes Malcolm Gladwell, Blink: the Power of Thinking without Thinking (New York: Little, Brown, and Company, 2005) and Daniel Kahneman, Thinking, Fast and Slow (New York: Farrar, Straus and Giroux, 2011), among others. A contemporary psychologist even proposes that intuition should find broader application in psychotherapy, since spontaneity is "an essential and perhaps most important quality of psychic life, sustaining all forms of creativity"; see Gemma C. Fiumara, Spontaneity: A Psychoanalytic Inquiry (New York: Routledge, 2009), 4. See Danto, "Modernism”, 61-77. Theodor W. Adorno, Aesthetic Theory, trans. Robert Hullot-Kentor (Minneapolis: University of Minnesota Press), 58 .

Ibid., 128. Plato, "Symposium", 202e-204c, in Selected Dialogues of Plato, 248-50. Immanuel Kant, "Preface to the First Edition, 1790", in Critique of Judgement (2007 rpt.), trans. James Creed Meredith (New York: Oxford University Press, 1952), 3-4, 13-4. Ibid., 21. 
to law. ${ }^{19}$ An heir to idealist aesthetics, Schiller (1759-1805) portrays Kant's abstruse notion in concrete poetic terms. He calls the artist a daemon, who, driven by the 'play impulse' (der Spieltrieb) strives to produce the Ideal through the union of the possible with the necessary. ${ }^{20}$ In this aesthetic state of free play with beauty, the artist is "at the same time in the condition of utter rest and extreme movement". ${ }^{21}$

Scholars have noted parallel expositions between Schiller's aesthetic state of 'free play' and the Buddhist 'play in samādhi' (youxi sanmei 遊戲三昧). ${ }^{22}$ Samädhi is a meditative state where consciousness is concentrated and the distinction between subject and object is nullified. The mind of the Chan practitioner can thus respond to things spontaneously and instantaneously, its meditativeness undisturbed. ${ }^{23}$ This is a spiritual state of simultaneous dynamism and stillness. Both doctrines aim at liberation. Schiller regards all aesthetic experience as potentially liberating because it is disengaged from the material. For instance, the audience take pleasure in the representation of tragedy or violence because they do not experience the object per se, but only the 'resemblance' of it. In a state not unlike that of disinterestedness, the practitioner in samādhi will not 'abide' in any illusory form. Thus, he will feel neither attachment nor disgust. ${ }^{24}$ Non-abiding also means that one does not need to sit in meditation in order to be immersed in a meditative state of mind. Instead, various daily activities - the artistic included - can be pursued while the practitioner experiences a meditative state of mind in the dynamic process of physical mobility. ${ }^{25}$ Schiller's aesthetic education, moreover, carries the ethical agenda of fostering moral freedom. ${ }^{26}$ Likewise, what the Chan practitioner professes to pursue through art is the truth of this-worldly existence, by the pursuit of which aesthetics and ethics are intrinsically intertwined. ${ }^{27}$ Schiller's

19 Ibid., 117.

20 Johann C.F. von Schiller, On the Aesthetic Education of Man, trans. Reginald Snell (Mineola: Dover Publications, Inc, 2004), 52, 74-5.

21 Ibid., 81.

22 Wu Rujun 吳汝均, preface to Youxi sanmei: Chan de shijian yu zhongji guanhuai 遊戲三 昧：禪的實踐與終極關懷 (Taipei: Xuesheng shuju, 1993), II.

23 As characterised reportedly by Huineng 惠能, the Sixth Patriarch of the Chan lineage, in Platform Sūtra (Liuzu dashi fabao Tanjing 六祖大師法寶壇經), T no. 2008, 48.358b.

24 Ibid., 38.361a.

25 Wu Rujun, Youxi sanmei, 164.

26 Meanwhile, it is a social and political agenda, since Schiller understands the ethical reform of individual as a prerequisite to political reform. See Patrick T. Murray, The Development of German Aesthetic Theory from Kant to Schiller (Lewiston: Edwin Mellen Press, 1992), 49-52.

According to the Kyoto School philosopher Hisamatsu Shinichi 久松真一, the 
aesthetic freedom is realised in the world of appearance. ${ }^{28}$ And, despite the Buddhist truth of emptiness, the freedom of 'play in samādhi' presupposes a certain affirmation of the phenomenal world.

Not to risk over-comparison, all these notions point to the 'in-between-ness' of artistic spontaneity. If, for the idealist philosophers, the realm of Ideas is real, for Buddhists the realm of Nothingness is. Yet, the realm of art or samādhi provisionally redeems the truth value of the phenomenal world. Su Shi's take on the Buddhist discourse was oriented towards the affirmative aspects of art. Though it is in accordance with the 'this-worldly turn' in Chan Buddhism, I regard it as being inspired in more fundamental ways by Zhuangzian Daoism, a school of thought that Su Shi was viscerally familiar with.

Su Shi's writings on art liberally refer to the Zhuangzi, which he studied in his teens. As suggested in many Zhuangzian parables, 'artistic spontaneity' is the kind of craft ( $j i$ 技) that embodies the Way. In one story, a butcher shows great virtuosity in dissecting a bull and explains this by the fact that he is practised in seeing the invisible. Thus, his exercise was no longer a craft but a partaking of the Way. ${ }^{29}$ Like the butcher, humble craftsmen in the Zhuangzi often display the essence of the Way through their concentrated practice, be it making wheels, ${ }^{30}$ catching cicadas $^{31}$ or diving into rapids. ${ }^{32}$ As A.C. Graham com-

“subjectivity of the dynamic nothingness" (能動的無的主体), represented through Zen art par excellence, is the reason why the human is human. See Hisamatsu, "Zen geijutsu no rikai” 禅芸術の理解, in Zen to geijutsu 禅と芸術, ed. Furuta Shōkin 古田紹欽 (Tokyo: Perikansha, 1996), vol. II, 89 .

28 For Schiller's innovative reading of the Kantian Erscheinung (appearance) on this point, see Michael J. Kooy, Coleridge, Schiller and Aesthetic Education (New York: Palgrave, 2002), 109-10.

29 In the “Yangshengzhu” 養生主 chapter, Zhuangzi 莊子, Cook Ding 庖丁 butchered a bull in front of the King of Liang, showing marvelous skills. The king wanted to know the secret of his divine craftsmanship, and Ding replied that it took him three years of concentrated practice to see no longer a bull, but the inner structures of the bull; he butchered in accordance with the patterns of Heaven. See zZJS, 3.117-24.

In the "Tiandao" 天道 chapter, Zhuangzi, a wheelwright Bian 輪扁 advised King Huan of Qi to discard books, since written words were nothing but the dreg of the Sage's mind. He drew this insight from his own practice, as even his son could not be verbally taught to know the art of making wheels. See zZJS, 13:490-1.

31 In the “Dasheng” 達生 chapter, Zhuangzi, Confucius once met an old hunchback catching cicada with marvelous deftness. The old man told Confucius that it was not a result of his craft, but of the Way. He acquired the Way after endless practice. Now in catching cicadas he was so single-minded that none of the ten thousand things could break his concentration. See zZJS, 19.639-40.

In the "Dasheng" chapter, Zhuangzi, a man dived in the rapids where even fish could not swim. He then told Confucius that he did not have the Way. Rather, his skill was innate, 
ments, a Zhuangzian craftsman is "spontaneous from the very center of his being", and his motions "derive not from himself but from Heaven working through him". ${ }^{33}$ Heaven is silent but manifests itself in the natural formation and transformation of things. Emulating Heaven's silent creation, the practitioner gains hands-on, tacit knowledge of the Way. In the Zhuangzi, language is a vehicle to be left behind once it has fulfilled its mission of conveying meaning $^{34}$ - even though, ironically, its teaching of wordless truth can only be imparted by words.

The Zhuangzian craftsman has come to represent an archetypical artist who realises the pattern of Heaven through the words and works of man. Resonances of the Zhuangzi are found in literary theories from the third to the ninth century. The first work of systematic literary criticism by Liu Xie argues that the poet should make his mind "empty and still" before his composition, ${ }^{35}$ so that the forms of things come naturally to his mind and he can capture these forms like a stamped impression. ${ }^{36}$ Such an artist could compete with "the Heaven's craft"; 37 his artwork, like a natural object, would appear to have become as such by itself (ziran). This term, ziran, would also appear as an essential poetic style in Ershisi shipin 二十四詩品 (Twenty-Four Properties of Poetry) by Sikong Tu 司空圖 (837-908), a hermit in the Late Tang. The poem that expatiates on this property ends with the term tianjun 天鈞 (Nature, the Potter), a metaphor which appears in the Zhuangzi

to express the concept that the natural processes of change evolve myriads of forms in the world continuously and spontaneously, as a potter creates forms at will from clay. ${ }^{38}$

Unlike a common potter, the divine potter has no intentionality, and his craft is comparable to cosmic creation in Nature's workshop. If, as Wendy Swartz argues, ziran in the Six Dynasties primarily meant 'verisimilitude', 39 by the Late

grew with his nature, and completed as a matter of destiny, without him knowing how it came to become as such. See zzJS, 19.656-8.

33 A.C. Graham, Reason and Spontaneity (Totowa, NJ: Barnes and Noble, 1985), 186.

34 See zZJS, 26.944.

35 Yang Mingzhao 楊明照, Zengding Wenxin diaolong jiaozhu 增訂文心雕龍校注 (Beijing: Zhonghua shuju, 2000), 26.369.

36 Ibid., $46.566-7$.

37 Ibid., 40.495.

38 Maureen A. Robertson, “... To Convey What Is Precious: Ssu-K'ung T'u's Poetics and the Erh-shih-ssu Shih P'in", in Transition and Permanence, eds. David C. Buxbaum and Frederick W. Mote (Hong Kong: Cathay Press Limited, 1972), 344. 
Tang and especially the Song periods, this term had been firmly established to describe spontaneous expressions of the artistic mind, as seen in the myth of Su Shi as a spontaneous genius, to be dwelt upon in greater detail below.

Buddhism is another intellectual source which has contributed to the formation of this archetypical persona. Enlightenment ( $w u$ 悟) is generally described as liberation or a state of absolute spontaneity. The cognitive capacity of a practitioner, however, is limited. The qualitative leap from an unenlightened state to enlightenment thus requires the assistance of upāya (fangbian 方便), namely, 'means', 'expedient' or “skilful means". In Mahāyāna Buddhism, various forms of Buddhist teaching and practice are all declared to be provisional means, skilfully set up by the Buddha to teach the unenlightened. ${ }^{40}$ It includes not only concrete images or methods, but also such central teachings as that of nirvana itself. ${ }^{41}$

In Su Shi's time, 'lettered Chan' (wenzichan 文字禪) was gaining prominence among monastic and lay Buddhist circles, showing a turn from the negation to the affirmation of language. ${ }^{42}$ Proponents argued that language or, more specifically, literary composition could be used as a "skilful means" to pursue enlightenment. During the Southern Song, many critics even equated Chan with the practice of poetry, arguing for 'enlightenment' in poetry. A rhetorical device though it might be, it further complicated the relation between the two practices. According to Richard John Lynn, lying behind the Chan poetry analogy are the Daoist concepts of the spontaneous and the natural, especially as they appear in the Zhuangzi. ${ }^{43}$ In this hybrid intellectual system, poetry becomes a path (in Buddhist terms, $m \bar{a} r g a^{44}$ ) leading to the ultimate

40 Michael Pye, Skilful Means (Dallas: Gerald Duckworth and Co. Ltd, 1978), 1.

41 Ibid., 36.

42 Monographic studies on the 'lettered Chan' include: Du Songbai 杜松柏, Chanxue yu Tang Song shixue 禪學與唐宋詩學 (Taipei: Liming wenhua, 1976) and Chan yu shi 禪與詩 (Taipei: Hongdao shuju, 1980); Zhou Yukai 周裕鍇, Zhongguo chanzong yu shige 中國禪宗與詩歌 (Shanghai: Shanghai renmin chubanshe, 1992) and Wenzi chan yu songdai shixue 文字禪與宋代詩學 (Beijing: Gaodeng jiaoyu chubanshe, 1998); and Sun Changwu 孫昌武, Chansiyu shiqing 禪思與詩情 (Beijing: Zhonghua shuju, 1997).

43 Richard John Lynn, "The Sudden and the Gradual in Chinese Poetry Criticism: an Examination of the Ch'an-Poetry Analogy", in Sudden and Gradual: Approaches to Enlightenment in Chinese Thought, ed. Peter N. Gregory (Honolulu: University of Hawaii Press, 1987), 382 .

44 On language as path, see also Robert M. Gimello, "Mārga and Culture: Learning, Letters, and Liberation in Northern Sung Ch'an", in Paths to Liberation: the Mārga and its Transformations in Buddhist Thought, eds. Robert E. Buswell, Jr. and Robert M. Gimello (Honolulu: University of Hawaii Press, 1992), 371-438. 
goal of spontaneity, be it the Daoist Way or Buddhist enlightenment. Su Shi's understanding of art betrayed the influence of this doctrine.

So far, all these theories of artistic spontaneity focus on the maker of the work, namely, 'the artist', though it is a notion circuitously defined. A work of art is created by someone who is broadly recognised as an artist. (Imagine it was I, not Ai Weiwei, who took a photo with a raised middle finger in front of Tian'anmen - it would have been a selfie, not a work of art.) But to become an artist one must first make works that are broadly recognised - and purchased - as art. (If a painting by Van Gogh lay beside a sack of potatoes in a dark basement, how would it differ in value from the potatoes prior to someone buying the painting for a definitely-not-for-potatoes price?) The artwork and the artist are therefore two sides of the same coin made by the cultural, social and market fields of art. In point of fact, 'a spontaneous artist' cannot be empirically demonstrated, if such a person exists at all. The audience faces a finished work of art, not the working artist. Based on how they perceive and interpret the aesthetic appearance of the artwork, the audience may deduce that the artist has been 'spontaneous' in the creative process. They reach this conclusion based on their imagination, received critical tradition or, perhaps, biographical knowledge about the artist. Whether the artist has been spontaneous in creating the work therefore becomes an irrelevant question. What they may perceive as 'spontaneous art' is born only through the collaboration of the artist, the work, the audience and the elusive 'field'. Arguably, artistic spontaneity is a kind of enchantment created by the appearance of the work of art. This, in all likelihood, is the case of Su Shi.

\section{Su Shi as the 'Spontaneous Artist'}

Su Shi was born on 8 January $1037,{ }^{45}$ during the reign of Renzong 仁宗 (10101063; $r$. 1022-1063), into a local gentry clan at Meishan County, Sichuan. He would later be ranked, together with his father Su Xun 蘇洵 (1005-1066) and his brother Su Che 蘇轍 (1039-1112), among the 'Eight Masters of the Tang and the Song' in ancient prose (guwen 古文). Accounts of him conventionally begin with a long list of achievements: poet, master of prose, calligrapher, painter and connoisseur who opened a new era in Chinese literature and aesthetics; an original thinker whose eclectic intellectual system encompassed Confu-

45 In this book, years are generally converted to the international calendar, as are dates of birth and death. The dating format of events, however, is traditional (e.g. "the twelfth day of the tenth month"). Su Shi's biographical accounts follow SSNP. 
cianism, Daoism and Buddhism; a statesman whose official positions and periods of exile took him through a vast landscape of experience; a student of esoterism and, reputedly, the author of a pharmaceutical handbook; ${ }^{46}$ and a gourmet whose namesake dish, Dongpo Pork, is still relished on Chinese tables. The list goes on, perpetuating a myth of creative genius. Yet, if genius is enchanting, the perceived innocence of Su Shi's character is endearing. He is known for his self-deprecating humour in the face of adversity. He is seen as a man unrestricted by boundaries, be they in terms of literary genre, intellectual persuasion, field of endeavour, political loyalty or existential horizons. His last terms of exile to the semi-barbaric Huizhou (in modern Guangdong Province) and Hainan (in modern Hainan Province) were seen as journeys through which he teleologically reached complete spontaneity in art and life. A Japanese painting by an anonymous fifteenth-century painter from the Gozan Zen circle, now in the Metropolitan Museum of Art in New York, shows Su Shi walking in the rain, wearing the Hainan native's straw hat and wooden clogs, his mood one of complete equanimity. ${ }^{47}$ This is a conventional theme in traditional Chinese and Japanese literati painting. It implies that, as a supreme man of culture, Su Shi had managed to 'return' to nature.

Indeed, Su Shi's writing often impresses its reader as carrying strong rhetorical momentum, descriptive power and emotional appeal, such that its author must have embodied the Way - that he is at one with the creative force of the universe. This impression has been encouraged by Su Shi's own description of his writing process. As he famously claimed:

My writing is like a fountainhead gushing out ten thousand buckets of spring water, surging forth without choosing the ground. On the plains it dashes in broad waves and rapid torrents, easily travelling a thousand $l i$ in a single day. When it encounters mountains or rocks, it twists and turns, taking its form according to the forms of things. No one knows [how it will change]. What is knowable is that it always goes when it should and always stops when it must. It is as simple as that! Even I know nothing more than that.

46 This handbook, Su Shen liangfang 蘇沈良方 [Effective Medical Recipes of Su and Shen], was compiled after his death and was based primarily on the work of Shen Gua 沈括 (1031-1095; also read as Shen Kuo).

“Su Shi in a Straw Hat and Sandals” 東坡芒屐圖, Metropolitan Museum of Art Accession Number: 1975.268.39. URL: http://www.metmuseum.org/collection/the-collectiononline/search/39659. Accessed 23 Febuary 2015. 


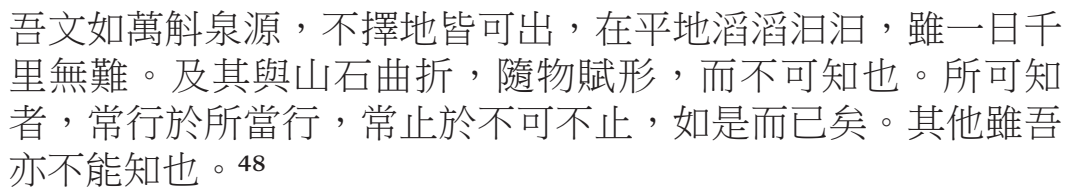

The river metaphor would become a stable element in a repertoire of critical parlance about Su Shi. A river is in constant motion. It bursts forth, urged by the pure impetus of creation, without "choosing the ground". ${ }^{49}$ The 'ground' is a generic term, referring to formal choices such as metre, rhyme, length or genre - in short, the very foundation that supports a literary work. In the appearance of a rapid torrent or a soft flow, his writing changes its momentum and takes its form "according to the forms of things".

$\mathrm{Su}$ Shi claims to know nothing about the making mechanisms of this linguistic marvel, except that his every word feels just right. In this self-portrait, Su Shi presents himself as unconscious of his art. Water is a conventional allegory of the Way. Su Shi, in his commentary on the Book of Changes, proposes that water has no constant form, thus it symbolises the supreme good; 50 it is in closest resemblance to the Way. ${ }^{51}$ Like water, the Way resides in the constant mutual transformation of opposites, but its movement reveals no intentionality. ${ }^{52}$ By comparing his writing to water, Su Shi appears to indicate that he gained the 'Way' of writing by discarding intentionality.

48 Su Shi, “Ziping wen” 自評文, sswJ, 66.2069.

49 Though this phrase may sound awkward to native English speakers, I choose literal translation because it is a significant rhetorical strategy for Su Shi to give agency to inanimate natural objects, a theme to be followed in the third chapter. His use might be inspired by Han Yu 韓愈 (768-824), who in a letter similarly talks about how his writing is "fetched from the heart and poured into the hands, coming like rapid torrents" 取於心而注於手 也, 泪泪然來矣; see “Da Li Yi shu” 答李翊書, in Ma Qichang 馬其昶, Han Changli wenji jiaozhu 韓昌黎文集校注 (Shanghai: Shanghai guji chubanshe, 1986), 3.170. Han Yu's emphasis, however, is not on writing in spontaneity, but rather on taking classics as the pure and single source of one's writing, to be internalised in rote memorisation, so that unadulterated words come 'naturally' to one's mind. The relation between memorisation and spontaneity will be explored in Chapter Two.

50 Here he cited Laozi, “the supreme good is like water” 上善若水; see Zhu Qianzhi 朱謙之, Laozi jiaoshi 老子校釋 (Beijing: Zhonghua shuju, 1984), 8.31.

It is not the Way per se, since the Way has no form; see Su Shi, Su shi Yi zhuan 蘇氏易傳, in San Su quanshu 三蘇全書, ed. Zeng Zaozhuang 曾東莊 (Beijing: Yuwen chubanshe, 2001), vol. 1, 7.353.

The comparison between water's lack of constant shape and the individual's lack of mind/intention has also been noted by Ronald C. Egan; see Egan, Word, Image, and Deed, 82. 
But can we take this claim literally? Many critics have noticed the skill and erudition in Su's writing, which could suggest artistic control. Nevertheless, the powerful metaphor of a gushing river not only dominates the reception of $\mathrm{Su}$ Shi's writing, it also overshadows other conflicting elements. Efforts were made later to redefine or subjugate these traces of the making process in order to effect a reconciliation with Su Shi's image as a spontaneous artist.

One way to explain away Su Shi's craft is to argue that it is not craft at all. According to Huang Tingjian 黃庭堅 (1045-1105), Su Shi's closest friend and disciple, the Master's making of his artwork was like the Creator's making of things.

Though Master Dongpo wears ceremonial jade, his heart is tranquil like a withered tree. ${ }^{53}$ Though he stands in court, his mind is among the East Mountains. How impossible it is to tell the vulgar minds about his relaxed manners and archaic style! [...] Tigers and leopards have their beautiful stripes, which are not artificial embellishments but have become as such by themselves. As for the humorous, cunning, deceitful, strange and jocular, which he represents with a fine rabbit-hair brush, they are particuarly divinely conveyed after drinking. So he sips goblet after goblet; then in tipsy drowsiness he frowns and stretches. Then he takes over the Creator's stove and hammer and uses them as his axe in carving a piece of literature.

東坡先生佩玉而心若槁木, 立朝而意在東山。其商略終古, 蓋 流俗不得而言。 [...] 虎豹之有美, 不彫而常自然。至於恢詭譎 怪滑稽於秋兔之頴, 尤以酒而能神。故其觞次滴瀝, 醉餘頻 申。取諸造物之鑪鍾, 盡用文章之斧斤。54

Huang was a prolific and influential critic. He often praised Su's heavenly endowed gift (tianzi 天資) ${ }^{55}$ and his moral stature which breathed heroism into his literary and artistic works. Su Shi's mind is described as free from the burden of power and wealth, and his artistic composition is likened to the unintentional functionality of nature itself. His spontaneity is a sign of his acquisition

53 In the 'Qiwulun' 齊物論 chapter, Zhuangzi, Nanguo Ziqi 南郭子綦 once sat in total oblivion of the world or himself, and his amazed disciple compared his form to a withered tree, his mind to dead ashes. See zzJs, 2.43.

Huang Tingjian, “Su Li hua 'Kumu daoren' fu” 蘇李畫枯木道人賦, Huang Tingjian quanji 黃庭堅全集 (Chengdu: Sichuan daxue chubanshe, 2001), zhengji 正集 12.298. See e.g. Huang Tingjian, “Ba Dongpo shu” 咙東坡書, entry III, ibid., zhengji 28.774. 
of the Way. As a result, his works of art seem to have "become as such by themselves". They show no trace of the making process, just like beautiful patterns on animal furs, they are a gift from nature. The "axe" he uses to carve a piece of literature is borrowed from the Zhuangzian craftsman, the wheelwright Bian, who boldly suggests that written words are nothing but the dregs of the Sage's mind and that the true way is grasped through concentrated, wordless practice. ${ }^{56}$ Now holding this proverbial axe, Su Shi applies it to the written word. Huang implies that, by virtue of his acquisition of the wordless Way, Su Shi is able to emulate the Creator's craft and compose in divine spontaneity.

Huang also suggests that Su's creation is enhanced by drinking. As a matter of fact, Su Shi was known to be fond of drinking, but did not have tolerance. He would soon get drunk and fall asleep. After a short nap, he would wake up and immediately grasp a brush to write or draw. ${ }^{57}$ As will be elaborated upon in Chapter Two, Su Shi mentions drinking as a method that helps the artist to lose conscious control during the process of composition. Compared with the acquisition of the Way, drinking appears to be a shortcut, but its advocacy further attests that artistic spontaneity is understood as the absence of self-consciousness.

Yet, for certain readers, Su Shi's claim to spontaneity was dubious. Significant efforts have been made to redefine his river metaphor. Even among his contemporaries, some critics argued that the weakness of Su's writing was precisely the byproduct of his spontaneous style. As the Song author Cai Tao 蔡條 (?-1126) commented:

Dongpo's poetry shows his vast and expansive natural genius, which is as illustrious as the sun and the moon. He has discovered and illuminated all those territories where the ancients had never reached. It is truly not excessive to compare his writing to 'a fountainhead gushing ten thousand buckets of spring water'. I only regret that he was like Dongfang Shuo ${ }^{58}$ whose unreserved remonstration sometimes mingled with jest, so it was rare to find in his words pregnant subtlety.

$56 \quad$ See "Introduction", fn. 3 o.

57 See Huang Tingjian, “Ba Dongpo zi hou” 跋東坡字後, in Huang Tingjian quanji, zhengji 28.771.

$5^{8}$ Dongfang Shuo 東方朔 (154-93 BCE) was a humorous rhapsody writer under Han Wudi 漢武帝 (156-87 BCE; $r$. 141-87 BCE). 
東坡詩, 天才宏放, 宜與日月爭光。凡古人所不到處, 發明殆 盡, 萬斛泉源, 未為過也。然頗恨方朔極諫, 時雜以滑稽, 故 罕逢蘊藉。59

Cai Tao understood Su Shi's "fountainhead" as the capacity to exhaust thematic and technical possibilities in poetry. This was a rather limited interpretation of the bursting creativity implied by Su's metaphor. Cai, moreover, did not regard creativity as a virtue in itself. Instead, he saw Su's unrestrained style as a weakness, resulting in the lack of "pregnant subtlety".

Another critical twist of the river metaphor came from Zhu Xi 朱喜 (11301200), the renowned scholar of lixue 理學 (literally 'the Learning of Principles'; also known as Song Neo-Confucianism), who saw Su Shi as his philosophical foe. In terms of literature, he condemned Su's style as too "crafty" (qiao 巧) and "flamboyant" (huali 華麗), its rhetorical flourish at best a distraction that trivialised the expression of the Way. ${ }^{60}$ Even so, he appeared quite familiar with Su's writing and occasionally acknowledged its power:

Although Dongpo's style is vast and broad like writhing waves, rolling forwards in a huge swathe, beneath the surface it is governed by laws.

東坡雖是宏闊瀾翻，成大片滾將去，他裏面自有法。61

Zhu Xi did not consider it contradictory to describe Su's writing as both spontaneous and somewhat crafty. In fact, he argued that it was the restraint within the unrestrained appearance that gave Su's writing its strength. This opinion showed Zhu's own philosophical and literary preference for rationality, moderation and control. ${ }^{62}$

Yuan Hongdao 袁宏道 (1568-1610), a Ming poet and essayist, praised the poetry of Su Shi as having broadened the horizon of poetry received from the Tang Dynasty. His writing dealt with subject matter, rules, emotions and virtual realms so exhaustively that it became "torrential and vast like a wide

59 Cai Tao 蔡條, Cai Baina shiping 蔡百衲詩評, in Song shihua quanbian 宋詩話全編, ed. Wu Wenzhi 吳文治 (Nanjing: Jiangsu guji chubanshe, 1998), 2518.

$60 \quad Z h u$ Xi 朱喜, Zhuzi yulei 朱子語類, in Zhu Zi quanshu 朱子全書, ed. Zhu Jieren 朱桀人 (Shanghai: Shanghai guji chubanshe \& Hefei: Anhui jiaoyu chubanshe, 2002), 139.4300, 4302, 4305-6, 4308, 4314.

$61 \quad$ Ibid., 139.4318.

62 A subject further explored in Zhiyi Yang, "Zhu Xi as Poet", Journal of the American Oriental Society (2012), 132.4: 587-611. 
river". ${ }^{3}$ As is obvious, Yuan almost literally borrowed Su Shi's metaphor; and, like Cai Tao, he understood it mainly in concrete terms, rather than as the unconscious outburst of some mystical creative force.

Due to revived interest in Song poetry, Su Shi attracted immense critical attention under the Qing. Zhao Yi 趙翼 (1727-1814), better known as a historian, devoted two chapters in his discourse on poetry to Su Shi. He noted the display of skill and erudition of Su's poetry, but considered that Su's genius lay in transcending these elements:

A verse from Dongpo says, "A pure piece of poetry needs forging and tempering/ so as to extract mercury from lead". ${ }^{64}$ But the achievement of Dongpo's poetry does not lie in forging and tempering. What is marvellous about it is that his mind is empty and luminous, [his words] flowing out spontaneously, as if without any effort, while permeating naturally into [the reader's] heart and mind. This is his unique excellence.

\section{坡詩有云：“清詩要鍛煉, 方得鉛中銀。”然坡詩實不以鍛煉為 工, 其妙處在乎心地空明, 自然流出, 一似全不著力, 而自然 沁入心脾，此其獨絕也。65}

Zhao quoted Su Shi's exhortation to 'forge and temper' a verse, before quickly adding that the true marvel of Su's poetry was not made by his craft but instead in the spontaneous flow of his mind. As Zhao put it, his mind must be "empty" and "luminous", two adjectives that usually describe the Buddhist state of enlightenment. Zhao Yi proposed that Su's transcendental state of mind gave him the capacity to talk to the reader intimately and heart to heart. This was a secularised vision of dharma transmission. In Chan Buddhism, it was supposedly through wordless gestures or actions that the dharma had been transmitted from the mind of one patriarch to that of the next (yixinchuanxin 以心傳心,

63 Yuan Hongdao 袁宏道, “Xuetaoge ji xu” 雪濤閣集序, in Qian Bocheng 錢伯城, Yuan Hongdao ji jianjiao 袁宏道集箋校 (Shanghai: Shanghai guji chubanshe, 2008), 18.710.

64 This line comes from "Cui Wenxue Jia xiewen jianguo xiaoran you chucheng zhi zi [...]" 崔文學甲攜文見過蕭然有出塵之姿 [...], sssJ, 45.2441-2. The couplet in the received version has a minor variant in the second line: nai de 乃得, instead of fang de 方得. This poem offers a piece of advice for a younger poet. Lead and mercury ( $g$ ong 录 or shuiyin 水 銀 in Chinese) are Daoist inner alchemical terms; see ch. 5, 177. Exacting the mercury in lead stands for acquiring the life's essence from raw materials.

65 Zhao Yi, Oubei shihua 區北詩話 (Beijing: Renmin wenxue chubanshe, 1963), 57. 
'transmission of mind through mind'). ${ }^{66}$ Here, for Zhao Yi, the essential message of the author was conveyed not through a wordless gesture but, on the contrary, through learned words which only cultural insiders could fully grasp. Zhao used the word ziran twice to characterise Su's creative process, the same word used by Huang Tingjian to describe Su's artwork. Zhao implied that the spontaneity of the poet guaranteed the spontaneous formation of his words, which in turn guaranteed the appearance of spontaneity of the work, and, finally, the instinctive, unimpeded understanding of the audience. In this idealised vision of artistic creation and reception, the craft and erudition that Zhao noted in Su's poetry are conveniently ignored under the shining appearance of spontaneity.

Recent scholarship on Chan Buddhism points out that the lineal transmission of dharma was nothing but a constructed myth, a carefully maintained "optical illusion". ${ }^{67}$ The claim of the 'transmission of mind through mind' was a rhetorical strategy employed by certain Chan Buddhist schools to gain a competitive edge. ${ }^{68}$ Likely, the portrayal of Su Shi as a spontaneous artist was perhaps a similar optical illusion, a discursive mechanism created to eternalise his canonical status. Song author He Yuan 何茥 (1077-1145) reported that he had had the chance to see some of Su Shi's manuscripts and had found them layered with revisions. ${ }^{69}$ The fact that He Yuan found this anecdote worthy of narration and praise is telling. Like many, he must have thought Su's work to be the holistic overflow of a creative genius. Thus, upon discovering his manuscript, he was at once surprised and relieved: an image of Su Shi painstakingly revising his poems may not be as interesting, but it is a more inspiring example for normal talents like him to follow. Nevertheless, the 'gushing river' version becomes a myth through repetition. Su Shi's received portrait grows out of a palimpsest, on which all traces of paradox and inconsistency have been marginalised from memory.

66 Allegedly, when Saakyamuni Buddha once raised a flower in an assembly, only Mahākāśyapa smiled, showing his silent understanding. See Puji 普濟, Wudeng huiyuan 五燈會元 (Taipei: Guangwen shuju, 1971), 1.9.

67 Bernard Faure, Rhetoric of Immediacy (Princeton: Princeton University Press, 1991), 12-15.

68 See T. Griffith Foulk, "Sung Controversies Concerning the 'Separate Transmission' of Chan", in Buddhism in the Sung, eds. Peter N. Gregory and Daniel A. Getz (Honolulu: University of Hawaii Press, 1999), 221-94.

69 He Yuan, Chunzhu jiwen 春渚紀聞 (Beijing: Zhonghua shuju, 1983), 7.102. 


\section{Chapter Outline}

This book examines the conflicting discourses that have been neglected in the construction of the myth. It consists of five chapters, each exploring one aspect related to aesthetic or ethical spontaneity. Its logical structure is charted below.

\begin{tabular}{l|lll}
\hline $\begin{array}{l}\text { Aesthetic } \\
\text { chapters }\end{array}$ & Aesthetics of art & $\begin{array}{l}\text { Ch.1 } \\
\text { Ch.2 }\end{array}$ & $\begin{array}{l}\text { On the 'spontaneous artist' } \\
\text { On 'spontaneous art' }\end{array}$ \\
\cline { 2 - 4 } & Aesthetics of nature & Ch.3 & On rock connoisseurship \\
\hline $\begin{array}{l}\text { Ethics } \\
\text { chapters }\end{array}$ & Transformation of the self & Ch.4 & On Su Shi's emulation of Tao Qian \\
\cline { 2 - 4 } & Transformation of the body & Ch.5 & On inner alchemy \\
\hline
\end{tabular}

The first three chapters focus on aesthetics; the first two on the aesthetics of art, and the third on the aesthetics of nature. Of the aesthetics of art, Chapter One deals with the question of the artist, and Chapter Two that of artwork. If the theoretical paradigm of the first group appears atemporal, the subsequent chapters on ethics place the discussion in a historical framework. They explore Su Shi's attempts at the transformation of the self and of the physical body to 'return into nature', a return conditioned by cultural paradigms and religious liturgies. In all these explorations, the aesthetic and ethical spontaneity will be found to be in the 'Middle Way', the unimpeded resignation to necessity on the road towards absolute freedom and enlightenment - a goal that is presupposed but cannot be actualised.

Below is a chapter-by-chapter account of the contents.

Chapter One explores the metaphor of the poet as a perfect mirror, which reflects ten thousand forms spontaneously and simultaneously, while its own tranquillity remains undisturbed. This metaphor presents the archetypical artist as a Man of the Way. As Su Shi argues against his contemporary intellectual opponents, first, artistic education can be employed as "skilful means" to cultivate human nature towards enlightenment; second, since human nature is never perfect, one must, by necessity, hold on to the Mean between cultivation and resignation. He supported the idea of Buddhist monks seeking enlightenment through practising art, especially poetry. The long history of controversy concerning this issue in the Buddhist circles suggests its complexity. Su Shi's standpoint reflects the influence of the 'Threefold Truth' (sandi 三諦) theory of the Tiantai 天臺 sect. His elevation of poetry above other artistic means results, perhaps, from a fear of being enslaved by materiality and of the decay 
of material forms. In this last analysis, the poet as a perfect mirror is only a rhetorical device, since whenever the 'fleeting forms' are captured in language, reification and petrification occur. 'Spontaneity' and its opposite - art - are born simultaneously.

Chapter Two discusses the making of such excellent works with a seemingly spontaneous aesthetic appearance, characterised as pingdan 平淡 ('the even and plain'). According to Su Shi, this is the understated appearance beneath which hides ultimate skill and strength - a state to which a mature poet should eventually 'return'. It represents the equilibrium between mnemonics (practice) and oblivion (spontaneous resignation to one's imperfection). Corresponding to the 'in-between-ness' of art, the world of art is located midway between the phenomenal world and the ultimate Void, represented by Snow Hall (Su Shi's painting studio). Lastly, since Su understood human nature as imperfectible, the appearance of spontaneity remains technically imperfect and individualistic, a common feature observed in Song Dynasty aesthetics and art.

If the first two chapters examine a tendency in Song aesthetics towards 'art as non-art', Chapter Three examines the opposite phenomenon of natural objects being aesthetically appropriated - and consequently commoditised - as works of art. The case in point is Su Shi's connoisseur literature on garden rocks and inkstones. As Su understands it, the attachment to 'superfluous things' (zhàngwu 長物) poses a moral threat to the owner's mental freedom. He justifies his material possession, however, in terms of spontaneous natural attraction between the person and the thing. The objects are thus invested with agency and character (often personified as recluses), and their being in the connoisseur's possession is analogous to the literati's serving in the court. $\mathrm{Su}$ Shi's poetry often uses this set of rhetorical devices for various agendas, particularly concerning the transaction of objects, including gift exchange and barter. Just like in the Zhuangzi, useless trees are central to a philosophical system on spontaneous living; for Su Shi, the uselessness of 'superfluous things' is a highly useful discourse, legitimising the objects' possession, aestheticisation and commoditisation.

Su Shi's self-comparison to a useless tree opens the discussion on the ethics of spontaneity. Chapter Four examines how deliberate emulation of a literary precursor could be employed to construct a 'spontaneous' literary persona. Su Shi systematically matched Tao Qian's poetry during his last periods of exile in the Far South. Su understood the aesthetic features of Tao's poetry as having an ethical dimension. Through his emulation, Su Shi reinterpreted his exile as a result of his natural inclinations, just like Tao's reclusion. The exile might even be felicitous, a condition for his 'return' to an original state of authenticity and spontaneity. By assuming agency for his suffering, Su Shi claimed autonomy 
from fate and reasserted his freedom of choice. Meanwhile, his poetry betrays a sense of anxiety and dislocation in his natural and cultural habitat, as well as alienation from the political centre. As a result, he transformed Tao Qian's "Peach Blossom Spring” (Taohuayuan 桃花源) into an inner utopia. His 'return' into this inner realm was further influenced by Daoist alchemical practice and possessed esoteric features.

The last chapter explores Su Shi's relationship with death - the ultimate 'return'. It gives an outline of the history of his Daoist devotion, discusses his ambivalence towards immortality, investigates the various techniques he used (including herbal medicine and laboratory and physiological alchemy), and, lastly, explores his final resignation to fate. Contrary to earlier literature that was wary of Su Shi's Daoist devotion as being 'superstitious', I argue that Su Shi's pursuit of immortality was an essential part of his effort to explore the unknown and to fathom his fate. It was also an important aspect of his consistent pursuit of 'spontaneity' in life, as the ultimate achievement of inner alchemy is to make the physical body completely spontaneous, in harmony with the course of the universe. However, Su Shi's conviction of his opportunity for immortality was equivocal. His final reconciliation with death shows a structure similar to his theory of aesthetic spontaneity, namely a dialectic spontaneity that requires constant practice and unencumbered resignation when one's limit becomes known.

$\mathrm{Su}$ Shi was a prolific writer. The texts that this book cites are primarily from his literary works, supplemented by his treatises and commentaries on classics. This choice is as much deliberate as necessary. He only engaged with classical scholarship in limited periods, for the manifestly 'serious' purpose of entering a scholastic tradition. In contrast, his poetry and literary prose were produced consistently throughout his life and served a variety of purposes. I thus read them as thinking texts, representing a mind in transformation and in conversation with past and future readers.

Jorge Luis Borges once cited Han Yu's 韓愈 (768-824) passage on the unicorn, together with other seemingly unrelated texts, to read Franz Kafka. He argued that

Kafka's idiosyncrasy, in greater or lesser degree, is present in each of these writings, but if Kafka had not written we would not perceive it; that is to say, it would not exist.

He concludes emphatically, "The fact is that each writer creates his precursors. His work modifies our conception of the past, as it will modify the future.". ${ }^{70} \mathrm{We}$ 
may not necessarily agree with Borges that " $\mathrm{i}] \mathrm{n}$ this correlation the identity or plurality of men matters not at all". Suffice to say that literary precursors and progenitors are bound by acts of recognition and germination. Su Shi created his precursors like Zhuangzi and Tao Qian. This book, in turn, is part of a continuous exegetical effort that calls Su Shi to relive in the modern. 


\section{The Poet as a Perfect Mirror}

Su Shi is a poet of particular significance to many readers. When Lin Yutang 林語堂 (1895-1976), Chinese writer and bel esprit, came to the United States in 1936, he brought with him "a few very rare and ancient editions of works by and about this poet, for which all considerations of space were thrown overboard". It was not only for his planned book on Su Shi but primarily because he wished the poet's company while living abroad. ${ }^{1}$ Su Shi's works, it seems, are able to create a sense of endearment in his readers, especially when they are in dislocation. Lin further explained that the mere mention of Su Shi "always elicits an affectionate and warm admiring smile in China". Su, as the book title suggested, was a "gay genius", "possessing a gigantic intellect and a guileless child's heart”. Lin borrows Su's own poem to describe him in naturalistic terms:

Here was a man! All through his life he retained a perfect naturalness and honesty with himself. Political chicanery and calculation were foreign to his character; the poems and essays he wrote on the inspiration of the moment or in criticism of something he disliked were the natural outpourings of his heart, instinctive and impetuous, like 'the bird's song in spring and the cricket's chirp in autumn', as he once put it; or again they may be likened to the "cries of gibbons in the jungle or of the storks in the high heavens, unaware of their human listeners below". 2

Lin Yutang regarded Su's literary writing as the "instinctive and impetuous" outpouring of his heart, comparable to the animated sounds of nature. The comparisons of him to crickets, gibbons and storks suggest that Su Shi, in the process of writing, was utterly void of self-consciousness or intentionality, just like 'natural beings' uttering their patterned cries.

The last sentence of Lin's eulogy rephrases a couplet by Su Shi which praises the poetry of the Buddhist monk Daoqian 道潛 (1043-?), also known as Canliao 參翏. To reach this state of spontaneous creation, as Su argues, the poet should transform himself into a perfect mirror. His poem begins with the couplet:

1 Lin Yutang, preface to The Gay Genius: the Life and Times of Su Tungpo (New York: J. Day Co., 1947), ix.

2 Ibid., viii. 
道人胸中水鏡清 In the chest of this Man of the Way is a clear water-mirror,

萬象起滅無逃形 in which myriad forms arise or dissipate, having nowhere to hide. ${ }^{3}$

The clear surface of a water-mirror catches the reflections of the surrounding phenomenal world, but its tranquillity remains undisturbed. This capacity resembles that of the Buddha, whose mind is omniscient and in constant tranquil meditation. The person who possesses such a capacity is an enlightened being. Yet, Su Shi is also aware of the Buddhist taboo against "ornamented language" (qiyu 綺語). ${ }^{4} \mathrm{He}$ thus apologises for his friend:

\section{多生綺語磨不盡 Many reincarnations have not worn away your ornamented language, \\ 尚有宛轉詩人情 as you possess still the delicate sentiments of a poet.}

He argues that that Daoqian's poetry is only the spontaneous outpouring of his disposition:

\section{猿吟鶴唳本無意 Gibbons wail, storks honk - they have no intention [to be heard]; \\ 不知下有行人行 unaware that below them travellers are passing by. ${ }^{5}$}

Like natural beings that wail or honk, the monastic poet versifies spontaneous expressions of his mind. The readers become eavesdroppers.

Both Su Shi and Lin Yutang, however, ignored the fact that natural beings do not write. By writing down his verses in ink on paper, the poet was perpetuating the traces of his mind. Writing articulates the desire for literary immortality: unlike a wailing gibbon, the versifying poet expects to be read. The paradox between spontaneity and intentionality remains unsolved.

This chapter explores the ideal of a spontaneous poet as a perfect mirror. When Lin Yutang borrowed Su Shi's set of metaphors to describe the poet, Lin cast him in the cultural model of a 'Man of the Way'. In Chinese critical

3 Su Shi, “Ciyun Daoqian jian zeng” 次韻僧潛見贈, sssJ, 3.880.

4 The Four-Part Vinaya (Sifen lü 四分律), a vinaya broadly abided by all Buddhist lineages, prescribes that even chanting sūtras and preaching dharma must be timely, lest the words of dharma turn into "ornamented language". See Sifen lü shanfan buque xingshichao 四分律刪 繁補關行事鈔, T no. 1804, 23b, $136 \mathrm{c}$.

5 Ibid., 3.881 . 
parlance, the term for style, $t i$ 體, literally means the 'artist's body'. The spontaneity of the artist is understood as the origin of the spontaneity of his artwork. A spontaneous body is an enlightened body, or a body of the Way (daoshen 道身). Su Shi regarded that fine arts, poetry in particular, were means of moral cultivation, so that a practitioner would eventually embody the Way. I attempt to contextualise his theory in his contemporary Confucian debate on human nature, the relation between literature and the Way, and in the Buddhist controversy on the legitimacy of monastic poetry. Ultimately, his 'attachment' to language seems to belie his argument of its being a mere means in the pursuit of the Way. Such an attachment may be the 'spontaneous' expression of his nature; thus, even though it prevents him from achieving absolute spontaneity, it needs to be acknowledged as necessary.

\section{The Style, the Artist and the Way}

By the end of the eleventh century, the artist as a Man of the Way was an ideal type, common to theories of the major Chinese polite arts - poetry, calligraphy and painting, known as the 'three perfections' (sanjue 三絕) ${ }^{6}$ and generally practised by the literati class. These arts began to share common aesthetics of refinement, understatement and simplicity. The purpose of art was increasingly understood as expression instead of representation, and the artistic mind as the origin of its inspirational power. Qiyun 氣韻 (literally 'breath and tone'), a term which in pre-Song painting criticism mainly meant 'a lively representation', was now thought to reflect the nature of a painter and to originate from innate talent alone. ${ }^{7}$ The identification between the artist's 'body' and his style was finally and firmly sealed. ${ }^{8}$ It was in the Song that calligraphers' or poets' surnames were frequently coupled with the word $t i$ to describe their individual styles, such as Yan-ti 顏體 (the calligraphic style of Yan Zhenqing 顏真卿 [709-785]), Bo- $t i$ 白體 (the poetic style of Bo Juyi) or Su- $t i$ 蘇體 (the poetic or calligraphic style of Su Shi). For the genteel artists of the late eleventh century,

6 A phrase first coined during the eighth century in praise of the Tang poet-painter Zheng Qian 鄭虔 (d. 764). See Qi Gong, “The Relationships between Poetry, Calligraphy, and Painting”, in Words and Images: Chinese Poetry, Calligraphy, and Painting, eds. Alfreda Murck and Wen Fong (The Metropolitan Museum of Art and Princeton University Press, 1991), 11.

7 See Susan Bush, The Chinese Literati on Painting (Cambridge, Mass.: Harvard University Press, 1971), 15-22.

8 For the anatomical or physiognomic connotations of Chinese terms for style, see Peter Charles Sturman, Mi Fu: Style and the Art of Calligraphy in Northern Song China (New Haven: Yale University Press, 1997), 6-7. 
the supreme artist was a 'Man of the Way'; his creativity found expression through multiple art genres, regardless of their different skill sets or material media; his expression consistently and adequately conveyed his mood and feelings of the moment; and the purity of his expression attested to his moral nobility. Aesthetics and ethics were intimately related in the eleventh-century critical discourse.

Su Shi was an exemplary achiever in these three arts. He was also a critic who first advocated their unity ${ }^{9}$ and developed the theories of literati art. ${ }^{10} \mathrm{Su}$ Shi's criticism reveals a penchant for characterology. When he appreciates a painting, a calligraphy scroll or a poem, he frequently refers to its author's mind and character to explain the aesthetic features of the work. And, despite the high virtuosity of the professional artists, he views the literati artists as being superior because of the transcendence of their mind. ${ }^{11}$ The literati's hubris aside, his aesthetic theory was grounded in his understanding of the Way and of human nature.

The rhetorical importance of the Way as the origin of excellence in art is a unique feature in Chinese aesthetic discourse. Wen 文 literally means 'the pattern'. On a cosmic scale, it refers to the manifestation of the Way in the phenomenal world. Thus, studying the cosmic wen leads to the knowledge of the Way. The Book of Changes declares:

[The Sage] looks up to observe the patterns of Heaven and looks down to examine the forms of the Earth, so as to know the causes of darkness and light.

More accurately, Su Shi often claimed that poetry and painting shared the same principle; see e.g. Su Shi, “Shu Yanling Wang Zhubu suo hua Zhezhi ershou” 書鄢陵王主簿所畫折 枝二首, sssJ, 29.1525; “Ciyun Wu Chuanzheng “Kumuge” 次韻吳傳正枯木歌, sssJ, 36.1961-2. His discussion on calligraphy, however, seems to fall largely into the same theoretical frame. For more on this issue, see Liu Guojun 劉國珺, Su Shi wenyi lilun yanjiu 蘇軾文藝理論研究 (Tianjin: Nankai daxue chubanshe, 1984), 122-8; Murck and Fong, introduction to Words and Images, xv; Leng Chengjin 冷成金, Su Shi de zhexue guan yu wenyi guan 蘇軾的哲學觀與文藝觀 (Beijing: Xueyuan chubanshe, 2003), 623-38.

$10 \mathrm{Su}$ is generally regarded as the founding figure of 'literati painting' (wenrenhua 文人畫) theories, though he probably did not have the same kind of painting in mind when Dong Qichang 董其昌 (1555-1636) finally coined this term. See James F. Cahill, “Confucian Elements in the Theories of Painting", in Confucianism and Chinese Civilization, ed. Arthur F. Wright (New York: Atheneum, 1964), 91; Bush, Chinese Literati, 1-3, 13; Jerome Silbergeld, "The Yuan 'Revolutionary' Picnic: Feasting on the Fruits of Song (An Historiographic Menu)", in Ars Orientalis (2009), 9-31.

11 See e.g. “Wang Wei Wu Daozi hua” 王維吳道子畫, sssJ, 3.108. 


\section{仰以觀於天文, 俯以察於地理, 是故知幽明之故. ${ }^{2}$}

Wen is also a multivalent term. Among its dozen definitions, those related to the Way include:

(1) Patterned manifestation of cosmic principle.

(2) Cultural accomplishment.

(3) Writing in the broad sense.

(4) 'Belletristic' literature; namely, those literary texts that, beyond their pragmatic functions, are concerned with aesthetic appeal, and hence resist being reduced to vehicles of propositional messages.

(5) (Within the fourth category) prose in particular.

Each definition suggests a fashion in which the Way could manifest itself, especially in human enterprises. And literature, as a 'patterned' way of human expression, is regarded as the vehicle by which the knowledge of the Way is articulated and perpetuated. Thus, when Liu Xie titled the first chapter of his work “The Investigation of the Way" (Yuandao 原道), he declared in the first sentence, “The patterned language is the heart of Heaven and Earth!" 言之文 者天地之心也.13 Liu's own highly elaborated style helped to show that, by the "patterned language", he was using wen in the specific sense of belletristic literature.

Belletristic literature, however, also entertains. One of the contentions in the eleventh century regarded the legitimacy of literature as a means of transmitting the Way. The argument begins with the claim that knowing the Way does not rely on literary practices. One can follow virtually any path of endeavour, be it governance, scholarship, meditation, religious devotion, moral cultivation or even practical crafts - the last kind of means is particularly evident in the Zhuangzi, where craftsmen's concentrated practices show their superior understanding. It is questionable if literature has any privileged access to the Way. One may argue, however, that language is needed to transmit the knowledge of the Way. But if that is the primary function of literature, then skilful writing, which entertains and distracts the reader, could be dispensed with. Zhou Dunyi 周敦頣 (1017-1073) proposed that "literature is the vehicle of the Way” 文所以載道也. ${ }^{14}$ Decorations should be minimal - sufficient to make

\footnotetext{
12 “Xici shang” 繫辭上, Zhouyi zhengyi 周易正義 7.65, ssJzs, 77.

13 Yang Mingzhao, Zengding Wenxin diaolong jiaozhu, 1.1.

14 Zhou Dunyi 周敦頣, Zhou Lianxi ji 周濂溪集 (Congshu jicheng edition. Shanghai: Shangwu yinshuguan, 1936), 6.117 .
} 
the vehicle desirable, but not overdone to waste the maker's effort or distract the viewer's attention. Aesthetic pleasure in literary practice was seen by Zhou and the lixue scholars following his lead as dangerous, since a student might indulge in such a refined pleasure and forget his proper pursuit of the Way. In other words, the means might become the end. Cheng Yi 程頣 (1033-1107), Su Shi's contemporary and opponent, thus declared that "crafting literature harms the Way" 作文害道. ${ }^{15} \mathrm{Su}$ Shi's view on the relation between literature and the Way was based on a very different view of human nature and was formulated in opposition to this categorical denunciation.

Before we compare Su and Cheng's opinions, however, we may trace Su's intellectual transformation on this topic. His early position was that of reluctance and antagonism. In a court memorial written in 1069, Su Shi chided "contemporary scholars" for "feeling inferior if they cannot discuss human nature (xing 性) or Heaven's decree (ming 命)". ${ }^{16}$ According to the Analects, Confucius never talked about human nature or the Way of Heaven. ${ }^{17}$ Su Shi thus recommended to his peers that they follow suit. Even though he did not name names, readers could not fail to note that the memorial was an indictment against the educational reforms of the newly promoted Prime Minister, Wang Anshi 王安石 (1021-1086).

Wang Anshi formulated his theory of human nature before his ascension in court. He argued that human nature in essence was beyond the dichotomy of good and evil, a dichotomy that arose only when man acquired sentience (qing 情). After the birth of this dichotomy, nature and sentience would then couple in mutual dependency, and neither would be purely good or evil. Yet, through education, people would be moved towards good. ${ }^{18}$ Wang consistently rejected the moral sufficiency of human nature and proposed the potential unity of self and society. The Sage sought to transform society by establishing models all men could conform to. ${ }^{19}$ Wang's moral philosophy provided the theoretical foundation for his political agenda. His 1069 education reform excluded literature (poetry and rhapsody) from the jinshi 進士 examination curriculum and

15 Cheng Yi opines that literary composition is just a plaything which distracts the student's concentration in the pursuit of the Way; see Cheng Hao 程影 and Cheng Yi 程頣, $E r$ Cheng ji 二程集 (Beijing: Zhonghua shuju, 1981), 239.

16 Su Shi, “Yi xuexiao gongju zhuang” 議學校貢舉狀, sswJ, 25.725.

17 Analects 5.14; see Liu Baonan, Lunyu zhengyi, 184.

18 See Wang Anshi, “Xing qing” 性情, “Yuan xing” 原性, and “Xing shuo” 性說, in Linchuan xiansheng wenji 臨川先生文集 (Beijing: Zhonghua shuju, 1959), 67.715, 68.726-7, 68.727-8, respectively.

19

Peter K. Bol, 'This Culture of Ours': Intellectual Transitions in T'ang and Sung China (Stanford: Stanford University Press, 1992), 226-8. 
focused solely on classical commentary and policy questions. Su Shi regarded it as nothing but folly, since the examination was meant to judge talent, not morality or administrative capacity. Furthermore, since the most upright people could not be enticed by fame or wealth, they would despise trading their moral capital for employment. Using 'morality' as the criterion of selection was self-defeating, as it encouraged only hypocrisy. ${ }^{20}$

If, by training, the literati specialised in cultural endeavours, by calling they were expected to be moral exemplars and skilful bureaucrats. Whether academic brilliance could be readily translated into administrative capacity was a cause of contention in the Song period. ${ }^{21}$ Wang's approach could not succeed unless he radically changed the whole system (of education, career training and channels of selection) from the ground. Su Shi regarded it as unnecessary and unrealistic.

Su's argument also reflected a very different view of the Way. If, for Wang Anshi, the Way was a moral and political concept, for Su Shi it was more comprehensive and was manifested in various cultural pursuits. Peter K. Bol summarised his position as "unity with diversity". 22 Furthermore, Su and Wang differed on the perfectibility of human nature, a difference shown in their respective conceptualisations of Sagehood (shengren 聖人). In the Song period, the concept of Sagehood was of "theological significance". ${ }^{23}$ It was a central metaphor upon which a system of moral philosophy was built. Wang Anshi regarded the Sage, in the singular and abstract meaning of the word, on a par with Heaven-and-Earth; a perfected moral being, ${ }^{24}$ capable of (and therefore responsible for) rectifying the world. Su Shi, on the other hand, held that a sage was neither omnipotent nor omniscient. Instead, he had to go along with the tide of his time and accomplish his goals in accordance with established ways. ${ }^{25}$ For Su Shi, a sage did not have a 'perfected' nature, but represented the highest potential that man could achieve. Lastly, where Wang Anshi regarded moral standards as absolute, Su Shi regarded them as relative to human situations.

\footnotetext{
20 Su Shi, "Yi xuexiao gongju zhuang", sswJ, 25.723-6.

21 For a comprehensive account on this issue, see Zhu Shangshu 祝尚書, Songdai keju yu wenxue kaolun 宋代科舉與文學改論. Zhengzhou: Daxiang chubanshe, 2006), 190-209.

22 Bol, 'This Culture of Ours', 254-99.

23 A phrase used by Michael Lackner in regard to Zhang Zai's conceptualisation of the Confucian Sage; see Michael Lackner, "Holy Within and Without: Zhang Zai's Teachings of Confucius's Two Natures”, Higashi ajia bunka kōjū kenkyu (bessatsu) 東アジア文化交渋 研究 (別冊) (2008). 3: 25-40.

24 Bol, 'This Culture of Ours', 228.

25 Su Shi, "Yi xuexiao gongju zhuang", sswJ, 25.723.
} 
The locus classicus of the Confucian doctrine on human nature was the Doctrine of the Mean, originally a chapter in the Book of Rites. Its very first sentence declares: "What Heaven has decreed is called nature" 天命之謂性. Through the Song, the Doctrine eventually became a core Confucian classic because its metaphysical interests offered a platform for the Song thinkers to articulate their thoughts. Most theories on human nature in the Song period, for instance, were formulated as commentaries on the Doctrine of the Mean, written by Buddhists and Confucian scholars alike. ${ }^{26}$ Su Shi wrote a treatise on the Doctrine in 1061, the same period in which he wrote treatises on the Changes, Documents, Odes, Rites and the Spring and Autumn Annals. The contemporary fashion had clearly influenced Su, so that he regarded the Doctrine as on a par with the other Five Classics (whose classical status had been established since the late third century BC). Nevertheless, his focus was markedly different from many of his contemporaries'. Consistent with his official position (namely, scholars should not talk about what the Master in the Analects remained silent about), he avoided defining human nature and even suggested that the first passage in this classic was blatant interpolation. His exegesis was centred instead on "genuineness" (cheng 誠), a crucial term appearing in the twentythird chapter of Doctrine. It states:

It is in [human] nature to acquire illumination from genuineness; it is in teaching to realise genuineness from illumination. Once genuine, one is illuminated; once illuminated, one is genuine.

\section{自誠明, 謂之性。自明誠, 謂之教。誠則明矣, 明則誠矣。}

Su proposes that illumination (ming 明) is knowing, which does not necessarily lead to doing. One acts only when one takes genuine delight (le 樂) in what one knows and is about to do. A sage is the one who takes delight in the Way, not the one who knows the most about the Way. If a common person were to know that even a sage cannot accomplish the ultimate task, he would be encouraged to follow suit and feel at ease with the most difficult moral command - as long as he has tried his best, there is no shame in fallibility. On this

26 Treatises on Zhongyong from Early Song to Su Shi's time include: Qisong 契嵩, “Zhongyong jie” 中庸解, in Tanjin wenji 鐔津文集, 巴 no. 2115, 52.665c-667c; Fan Zuyu 范祖禹, “Zhongyong lun” 中庸論, in Huang Zongxi 黃宗羲, Songyuan xuean 宋元學案, in Huang Zongxi quanji 黃宗羲全集, vol. 4 (Hangzhou: Zhejiang guji chubanshe, 2005), 21.78-85; Cheng Yi (or Cheng Hao), “Zhongyong jie” 中庸解, in Ercheng ji, jingshuo 經說 $8.1152-65$. 
ground, Su glosses 'holding on to the Mean' (zhizhong 執中) as 'constantly at the Mean' (shizhong 時中). As he argues, one will necessarily deviate from the Mean, but one should keep trying and constantly come back to the Mean. This is why, as Su Shi notes, Confucius praised Yan Hui 顔回 for holding onto the Way for no longer than three months at a time. ${ }^{27}$ The Mean is grounded in human sentience as well as in human limits. Everyone has their own standard of the Mean; by improving one's moral nature, one pushes the Mean towards the standard of the sage. This dynamic definition encourages a person to answer the highest moral call without exceeding his present capacity. He can then take delight in fulfilling moral commands without being crushed by the challenge. He may not achieve absolute moral freedom, but he will continuously improve his nature while finding no obstacle or shame in the acceptance of his imperfection. This dialectic state is seen as the state of ethical spontaneity.

$\mathrm{Su}$ Shi did discuss human nature, however, in other essays written in the same period, which suggests that his avoidance in the aforementioned treatise was deliberate. In essays on Yang Xiong 揚雄 (53 BC-18 $)^{28}$ and $\mathrm{Han} \mathrm{Yu},{ }^{29}$ two precursors who had contributed to the topic, he proposes that human nature was neutral. Like a tree, it has the tendency to grow. This tendency is in its nature and is common to all trees. Yet its individual potentiality (cai 才) determines whether its timber becomes hard or soft, big or small. Su Shi's position was akin to that of Gaozi 告子, Mencius' opponent who compared human nature to the willow. ${ }^{30}$ Su's theory also showed the influence of Qisong 契嵩 (1007-1072), a senior Buddhist scholar whom Su Shi met in person and held in great admiration. ${ }^{31}$ Qisong's seminal treatise on the Doctrine of the Mean initiated the Song discussion. In this treatise, he proposed that humans share a common nature, while their sentience is specific to individuals. ${ }^{32}$ Himself an ascetic monk, Qisong defined sensual desires, such as those for food and sex, as part of human nature. Similarly, contrary to those who denounced sentience as the origin of evil, Su Shi regarded instinctive physical desires as not only legitimate but indeed necessary. In his later theories of human nature, this position remained unchanged.

27 Su Shi, “Zhongyong lun” 中庸論, sswJ, 2.60-64. On Confucius' praise of Yan Hui, see Analects 6.7.

28 Su Shi, “Yang Xiong lun” 揚雄論, sswJ, 4.110-1.

29 Su Shi, “Han Yu lun” 韓愈論, $s s w J, 4.113-5$.

$30 \quad$ See Mencius, 11.1

31 According to Dongpo zhilin 東坡志林, Su Shi was by Qisong's deathbed when he passed away in 1072 in Hangzhou. See “Gu Nanhua zhanglao Chong Bian shi yishi” 故南華長老 重辯師異事, Dongpo zhilin (Beijing: Zhonghua shuju, 1981), 3·51-2. 
These early writings reflected Su Shi's paradoxical attitude in the discussion of human nature. ${ }^{33} \mathrm{He}$ also maintained that no universal definition of human nature could be found, in which sentience - the individual response to external stimuli - was apparently regarded as part of human nature. Though his thinking on this topic was not systematic, his definition showed the unique feature of being both physical and individualistic. These features remained in his later and more mature conceptualisation, developed in his commentary on the Book of Changes. The writing began during his exile in Huangzhou (10831084), and was finished during his last periods of exile in Huizhou (1094-1097) and then Hainan (1097-1100). It integrated an earlier draft by his father Su Xun, and was further supplemented by his brother Su Che. Nevertheless, Su Shi's voice was the dominant one in this family project. ${ }^{34}$

Su Shi's argument on human nature consists mainly of three aspects. First, just like the Way, human nature is invisible and ineffable - neither good nor evil. Su compares the Way to sound, and human nature to hearing; the former exists independently, while the latter comes into being only in the presence of a sentient agent. Put differently, every human being's original nature is an individual manifestation of the Way. Being good or evil is the result of human nature coming into contact with external things. ${ }^{35}$ Second, good and evil coexist in varying proportions within an individual. Moral cultivation or moral abandon changes the proportion, but it cannot eliminate the existence of either. Thus, even sages like Yao and Shun could not eliminate the element of evil from their nature, and nor could villains eliminate that of good. That which cannot be eliminated is innate in nature. ${ }^{36}$ Third, man must go back to the origin to meet the unity of the invisible (human nature) and the visible (Heaven's decree). Their unity is unreflective and spontaneous, like feeling hungry and eating food, ${ }^{37}$ or thinking of and using one's hands. ${ }^{38}$

Su Shi's mature understanding of human nature differed sharply from that of Cheng Yi, his opponent in court and in philosophy. Cheng followed Mencius in declaring that "human nature is originally good". ${ }^{39}$ His theory was based on the belief in the perfectibility of human nature and in man's cognitive capacity to know the Way in its totality - which Su Shi regarded as impossible, even for

33 As also shown in Su Shi, "Zisi lun" 子思論, sswJ, 3.94-5.

34 In my subsequent analysis, I will treat the basic arguments as Su Shi's, thus far an approach taken by scholarly consensus.

35 Su Shi, Su shi Yi zhuan, 142, 352.

36 Ibid., 142.

37 Ibid., 392.

38 Ibid., 142.

39 Cheng Hao and Cheng Yi, Ercheng ji, yishu 遺書 18.187. 
a sage. Cheng Yi argued that, to realise the Way, one should examine one's "original mind" (benxin 本心) ${ }^{40}$ and hold onto the Mean, which he defined as "what is correct". ${ }^{41}$ This definition of the Mean was categorical and remained unchanging to every man - in sharp contrast with Su Shi's contingent and individualist understanding.

Cheng Yi's theory was largely inherited by Zhu Xi, the giant of Southern Song Confucianism. The differences between Su Shi's and Zhu Xi's philosophy have long attracted scholarly attention. Peter K. Bol argues that Zhu Xi represented a narrowed intellectual tradition, in which the moralistic 'Learning of the Way' (daoxue 道學) eclipsed the diversity of cultural accomplishments (wen) represented by Su Shi. By giving priority to learning from past experience and the apprehension of the Way as sources of values, Su and his followers contributed to the reevaluation of the role of culture in literati life. ${ }^{42}$ Michael A. Fuller further argues that one major distinction between the poetics of $\mathrm{Su}$ Shi and Zhu Xi was over the epistemological adequacy of language in representing patterns that underlie the phenomenal world. ${ }^{43} \mathrm{Zhu}$ Xi believed in the adequacy of language and of one's cognitive capacity, but Su Shi was sceptical. For him, it was not only that the Way and human nature proper cannot be known, but also that language cannot adequately express what one did know. His agnostic view of the Way is best expressed in the essay "The Sun Analogy" (Riyu 日喻), where Su Shi argues that a person born blind cannot know the sun; using analogies to instruct him on the shape or the warmth of the sun may even create further confusion. This situation is analogous to that of the unenlightened trying to know the Way - a vain undertaking. ${ }^{44}$

Su Shi's emphasis on empirical knowledge relates his moral philosophy to his aesthetic theory. Creativity was essential to the pursuit of the Way exactly because “the Way can be acquired but not sought” 道可致而不可求; 45 namely, one could 'acquire' the Way through hands-on practice but not 'seek' it through moral didactics. To further understand this proposal I will take a close look at the essay "Seeing off Sicong", in which Su Shi advises a young monk to seek enlightenment through artistic pursuits. Su was clearly aware that his ad-

$40 \quad$ Cheng Yi, “Zhongyong jie”, ibid., Jingshuo 經說 8.1152.

41 Ibid., Jingshuo 8.1153.

42 Bol, 'This Culture of Ours', 259; see also 340-1.

43 See Michael A. Fuller, "Aesthetics and Meaning in Experience: a Theoretical Perspective on Zhu Xi's Revision of Song Dynasty Views of Poetry", Harvard Journal of Asiatic Studies (2005), 65: 311-56.

Su Shi, "Riyu", sswJ, 64.1981. This essay is also examined in Bi Xiyan, Creativity and Convention in Su Shi's Literary Thought (New York: Edwin Mellen Press, 2003), 73-4. 
vice contradicted the Buddhist taboo against 'ornamented language'; indeed, the reason for this taboo was very similar to his fellow Confucian scholars' antagonism to belletristic literature.

\section{The Education of the Artist as a Young Monk}

In the fourth month of 1091, Sicong 思聰 (1063-after 1094), a young monk from Hangzhou, was about to bid Su Shi farewell. The picturesque city of Hangzhou, the centre of Chan Buddhism, was where Su Shi spent his two provincial tenures and made acquaintance with famous monks, many of whom were poets. He concluded his second term earlier that year and returned to the capital Kaifeng, waiting for reassignment. Very likely, Sicong had accompanied him on the journey and was about to return. Su Shi thereupon wrote an essay for him; he advised Sicong not to rely on the study of sūtras alone but to practise various fine arts to achieve enlightenment, in order to transform himself into a perfect water-mirror. Below, I have translated the essay in three parts.

\section{Seeing off Sicong, a Monk from Qiantang, on His Return to the Solitary Hill \\ 送錢塘僧思聰歸孤山敘46}

[1] Heaven gives rise to water by the virtue of One. Earth completes it by the virtue of Six. When the virtues of One and of Six match, Water appears. ${ }^{47}$ Even the divine $\mathrm{Yu}^{48}$ could not tell the One from the Six as its cause. Master Zisi said, "It is in [human] nature to acquire illumination from genuineness; it is in teaching to realise genuineness from illumina-

46 Su Shi, "Song Qiantang seng Sicong gui Gushan xu", sswJ, 10.325-6.

47 This appears to be a summary of numeric cosmology as speculated in the Book of Changes and the Book of Documents. According to the "Xici" 系辭 chapter in the Book of Changes, One and Six, among other numbers, are assigned to Heaven and Earth respectively as their numeric virtues; see Zhu Xi, Zhouyi benyi 周易本義, in Sishu Wujing 四書五經 (Beijing: Zhongguo shudian, 1985), vol. 1, 6o. The commentators to the "Hongfan" 洪範 chapter in Shangshu further expatiates this theory according to the Five Phases scheme. Zheng Xuan 鄭玄 proposes that "the virtue of One in Heaven gives birth to Water in the north...the virtue of Six in Earth complements the birth of Water in the north, and combines itself with the One of Heaven"; see Sun Xingyan 孫星衍, Shangshu jinguwen zhushu 尚書今古文注疏 (Beijing: Zhonghua shuju, 1986), 12.296.

48 Yu was the mythological hero who tamed the cosmic flood. See Sima Qian 司馬遷, Shiji 史記 (Beijing: Zhonghua shuju, 1959), 2.50-2. 
tion. Once genuine, one is illuminated; onceilluminated, one is genuine". 49 When genuineness and illumination match, the Way appears. Not even the Yellow Emperor or Kong Qiu [aka. Confucius] could tell genuineness from illumination as its cause. The Buddha said, "Precepts give rise to concentration, and concentration gives rise to wisdom". ${ }^{50}$ Why could wisdom not conversely give rise to concentration? Jester Darkness (Lingxuan 伶玄) said, "Wisdom gives rise to facility; facility gives rise to overflow". ${ }^{51}$ How could he claim to know the true wisdom! When a man is intoxicated, his behaviour is bewildered; when he sobers up, his bewilderment halts. This shows that wisdom results in concentration, while facility will not result in overflow! For the same reason, when a man has eyes, he can walk by himself. Even when he lifts his robe and walks fast, often he will find the broad way. When a man has no eyes, he must follow. Even when he holds to a wagon and treks after the wheel, often he will tumble into pitfalls. Evidently, it is faster for wisdom to bring out concentration than for concentration to bring out wisdom!

天以一生水, 地以六成之, 一六合而水可見。雖有神禹, 不能 知其孰為一、孰為六也。子思子曰：“自誠明謂之性。自明誠謂 之教。誠則明矣, 明則誠矣。”誠明合而道可見。雖有黃帝、孔 丘, 不能知其孰為誠、敦為明也。佛者曰：“戒生定, 定生 慧。”慧獨不生定乎? 伶玄有言: “慧則通, 通則流。”是鳥知真 慧哉? 醉而狂, 醒而止, 慧之生定, 通之不流也審矣。故夫有 目而自行, 則褰裳疾走, 常得大道。無目而隨人, 則扶輪曳 踵, 常仆坑阱。慧之生定, 速於定之生慧也。

This paragraph parades citations from various origins and registers. It starts with the Book of Changes, then proceeds to the Confucian Doctrine of the Mean, then to the Buddhist Süramgama Sūtra, and finally to Zhao Feiyan waizhuan

49 Reference to The Doctrine of the Mean, entry 21; see Zhu Xi, Zhongyong zhangjujizhu 中庸 章句集注, in Sishu Wujing, vol. 1, 11.

5o In Śūramgama Sūtra, Śākyamuni Buddha declared to Ānanda, "To constrain the mind, this is the so-called precept. The precept gives rise to concentration, and concentration gives rise to wisdom - this is called 'three learnings that have no omission". See Dafoding Rulai miyin xiuzheng liaoyi zhu pusa wanxing shou lengyanjing 大佛頂如來密因修證了 義諸菩薩萬行首楞嚴經, T no. 945, 19.131c. Lingxuan 伶玄, Zhao Feiyan waizhuan 趙飛燕外傳, in Biji xiaoshuo daguan 筆記小說 大觀 (Taipei: Xinxing shuju, 1974), 8.5496. 
趙飛燕外傳 (The Unofficial Biography of Zhao Feiyan), 52 an erotic fiction of the lowest register in the textual tradition. All these lines are cited out of context. Su Shi plays upon the multivalent meaning of their key terms to string together a cohesive argument.

Cosmological correspondence theory suggests that Heaven possesses the virtue of One (unity), and Earth that of Six (multiplicity). Their union creates Water. Similarly, Su Shi argues that the Way comes from the perfect integration of "genuineness" and "illumination". In his treatise on the Doctrine of the Mean, Su defines "genuineness" as "taking delight in it [the Way of the Sage]", and "illumination" as "knowing it". "Genuineness" originates from human nature, while "illumination" comes from teaching. Genuineness is thus seen as the innate and instinctive quality that inspires a human to respond to the Way of Heaven. Complete internalisation of this quality makes a man a sage. Illumination is the knowing of the Way. Since water is the symbol of the Way, these two citations are juxtaposed to suggest that the Way appears through the perfect harmony of diversity and unity, or knowledge and practice. Their union is so perfect that even great sages cannot tell the elements apart.

The third and fourth citations are bound together by parallelism. They share the key word hui 慧 ('intellect' or 'wisdom'; Sanskrit prajñā) and are put into a dialogue over its relation with ding 定 ('meditation' or 'concentration'; Sanskrit samādhi). The first term of this triad, jie 戒 ('precepts' or 'morality'; Sanskrit ślla), is somehow left undiscussed. The original meanings of these citations, however, are quite different. In their original contexts, the third citation discusses the relation between a meditative mind and Buddhist wisdom, while the fourth comes from a line which comments, "As for indulgence in sex, only a clever man can do this. Cleverness gives rise to facility; facility gives rise to licentiousness".53 These two lines are now stripped of their contexts and are juxtaposed to create a new dialogue in which 'cleverness' and 'licentiousness' would be understood as 'wisdom' and 'overflow'. Then Su Shi overturns them both and proposes that it is quicker for wisdom to bring out concentration than the other way around.

This paragraph is remarkably skilful and defiant. The wisdom of sages and Buddha is challenged and trivialised, their words juxtaposed with those of Jester Darkness. Confucius is addressed by his proper name, Qiu. By breaking taboos and taunting authorities, Su Shi has gained a high rhetorical ground. But what is the issue? BCE). 
[2] Sicong, a monk from Qiantang [aka. Hangzhou], was good at playing the zither when he was seven. He put down the zither and started practising calligraphy when he was twelve. After he excelled in calligraphy, at fifteen he put down calligraphy and started studying poetry. His poems contain some truly marvellous lines! They read like clouds and mists forming a blue nebulosity, or big and small pearls shining and twinkling. Those who recognised his talent ranked him among the master painters [in poetry]. Yet Sicong did not stop. He proceeded to read sütras like the Avatamsaka and entered the realm of dharma with its oceanic wisdom. He is now twenty-nine sui. Old masters and erudite scholars all respect and cherish his talents. Qin Shaoyou ${ }^{54}$ took Bodhisattva Mañjuśri's words in Śüramgama Sütra and gave him the polite name Wenfu. ${ }^{55}$

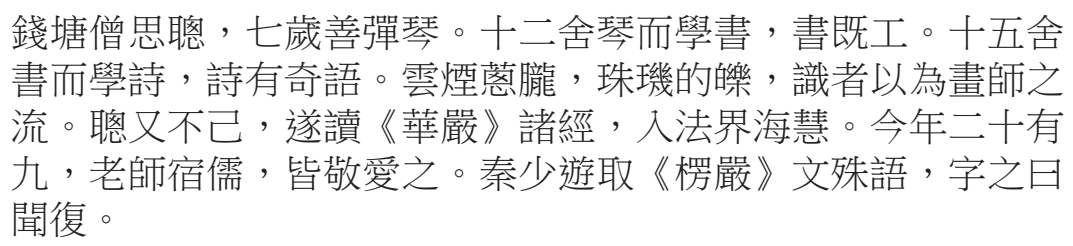

From the high ground of metaphysical speculation, the rhetoric in this paragraph plunges sharply in register. The addressee is now revealed to be a young monk from Hangzhou. Such skilful writing creates expectation. According to Su Shi, Sicong's education has progressed from music, to calligraphy, to poetry and, finally, to Buddhist teaching. It is a parody of a passage in the Analects where Confucius recounted how his insight increased along with his study at different ages. ${ }^{56}$ Sicong was a concrete example of the theory that intellect leads to concentration. Yet, presumably, this tonsured young artist reached prodigious depths in his religious study - a sign of his grounded mind.

The description of Sicong's education could have reminded Song readers of 'the Six Arts. ${ }^{57}$ The original curriculum contained disciplines like archery and

\footnotetext{
54 Shaoyou was the polite name of Qin Guan 秦觀 (1049-1100)

55 Wenfu literally means 'returning [to the root] upon hearing [the truth]'. According to the Śuramgama Sütra, "The three realms are like illusory flowers; returning [to the origin] upon hearing [this truth], and get rid of the root of illusion". See Shou Lengyanjing, T no. 945, 19.131a.

$56 \quad$ Analects 2.4.

57 The 'Six Arts', or liuyi 六藝, are defined in Zhouli 周禮 as ritual 禮, music 樂, archery 射, charioteering 御, writing 書 and mathematics 數; on the discussions and modifications of this curriculum in the following centuries, see Sun Yirang 孫詒讓, Zhouli zhengyi 周禮 正義 (Beijing: Zhonghua shuju, 1987), 26.1010-7.
} 
charioteering, which were hardly likely to be practised in the eleventh century. Rather, a Song Dynasty gentleman would pursue an education in fine arts like poetry, calligraphy, painting or music. This diversified curriculum corresponds to the opening line, namely, when One and Six match, Water appears. If One is understood as wisdom and Six as various artistic practices, then such a combination will give rise to 'Water' - a symbolism to be expatiated upon in the next passage.

[3] If Sicong will progress daily without halt and reach the Way through hearing, reflecting and practising, then even Avatamsaka Sūtra with its oceanic wisdom in the realm of dharma will just become a guesthouse [to the Way], not to mention calligraphy, poetry and zither! Even so, no student of the Way since the olden times has ever entered its realm through emptiness. Just as the wheelwright Bian crafted wheels ${ }^{58}$ or the Old Hunchback caught cicadas ${ }^{59}$ - a thing is never too base if it inspires one's dexterity and intelligence! If Sicong would achieve the Way, then zither and calligraphy will both have helped, and poetry particularly so. If Sicong could imitate a water-mirror, which contains the myriad forms in its Oneness, then his calligraphy and poetry will become even more marvellous. I will observe them as signs of his progress towards the Way.

\section{使聰日進不止, 自聞思修以至於道, 則《華嚴》法界海慧, 盡 為蓬盧, 而況書、詩與琴乎。雖然, 古之學道, 無自虛空入 者。輪扁斫輪, 傴僂承蜩, 苟可以發其巧智, 物無陃者。聰若 得道, 琴與書皆與有力, 詩其尤也。聰能如水鏡以一含萬, 則 書與詩當益奇。吾將觀焉, 以為聰得道淺深之候。}

Su Shi acknowledges that the ultimate goal for a monk is to acquire enlightenment, and all his aesthetic education is but a kind of skilful means. Like other kinds of pedagogic forms or practices, in Mahayana Buddhism these are set up by the Buddha to teach the unenlightened. ${ }^{60} \mathrm{He}$, in effect, mentioned three paths to the Way: through Buddhist precepts and meditation, through fine arts like music, calligraphy and poetry, or through practical crafts (as in the Zhuangzian stories). If one progresses, every means will be left behind like a guesthouse. All skilful means in this respect are self destructive. As Michael Pye says,

\footnotetext{
58 See "Introduction", fn. 30.

59 "Introduction", fn. 31.

60 Pye, Skilful Means, 1. See also “Introduction”, 10.
} 
"in so far as they work, they bring about their own redundancy". ${ }^{61}$ It is not unlike in the Zhuangzi where a fish trap (the language) is to be discarded once the fish (the meaning) is caught. ${ }^{62}$ The difference among various means is consequently negligible, and aesthetic education is as legitimate as the study of sütras. The deliberate egalitarianism echoes the indifferent citations from sources of all registers in the first paragraph .

When he defines the function of these skilful means as "inspiring dexterity and intelligence", however, Su Shi intimates his preference for art over precept and meditation. As he has suggested earlier, "wisdom gives rise to concentration" quicker than the other way around. Water, a quintessential element defined in the beginning of this essay, reemerges now as a metaphorical image for an enlightened and meditative mind. Without disturbing its tranquillity, it reflects ten thousand forms faithfully and simultaneously. The image of a watermirror relates the ending to the first sentence of the essay, making it a closed circle.

The 'water-mirror' is an ancient metaphor. As Beata Grant has noted, it is often used in Confucian texts to refer to a person's particular perceptiveness, discrimination and vision. When used by Su Shi, it is further enriched by the Buddhist metaphor of the mirror, which reflects all the phenomena of the world without possessing them or being attached to them. ${ }^{63} \mathrm{Su}$ Shi elaborated upon this metaphor in another poem which eulogised Daoqian's poetic mind:

\section{靜故了群動 By the virtue of its tranquillity, it is aware of the myriad movements; \\ 空故納萬境 by the virtue of its emptiness, it contains ten thousand virtual realms. ${ }^{64}$}

Here the water-mirror metaphor differs from the mirror metaphor in Plato's mimesis theory. When Plato compares art to a mirror that reflects the forms in nature, ${ }^{65}$ he does not attribute to it any cognitive value. A 'water-mirror',

\footnotetext{
$61 \quad$ Pye, Skilful Means, 36 .

62 See the “Waiwu" 外物 chapter in the Zhuangzi; zzJs, 26.944.

63 Beata Grant, Mount Lu Revisited: Buddhism in the Life and Writings of Su Shi (Honolulu: University of Hawaii Press, 1994), 94.

64 Su Shi, “Song Canliao Shi” 送參胗師, sssJ, 17.906.

65 Plato, Republic, Book X, 596d; see The Republic of Plato, 279. Plato's analogy initiated a long tradition in European theories of art, though many used it differently to Plato, giving art higher power than being a mere reflector; see M.H. Abrams, The Mirror and the Lamp: Romantic Theory and the Critical Tradition (1971 rpt.) (Oxford: Oxford University Press, 1953), 30-46.
} 
however, does not merely reflect visible forms, but also reveals the 'movements' and 'virtual realms' which usually evade our sensory faculties. It represents the enhanced cognitive capacity of the poet in meditation.

Second, the tranquillity and emptiness of a meditative mind do not necessarily suggest a serene poetic style. According to Su Shi, Daoqian's poetry displays his "heroism and fierceness" (haomeng 豪猛). It is the same in the case of Sicong, whose poetry is elsewhere praised as "masculine and unconstrained" (xiongfang 雄放). ${ }^{66}$ It seems that their writing style is similar to Su Shi's, even though Su characterised his own style in terms of a gushing river. The tranquillity of a water-mirror and the dynamism of a gushing river appear to be in contrast; but both, in essence, are water, which acquires its tranquillity or mobility according to circumstance. When the gushing river becomes still, it is just like a water-mirror. Therefore, these two metaphors are united as symbolisms of the same water. Moreover, their difference is only a result of perspective. If the meditative mind is tranquil, then the fleeting forms reflected upon its surface are dynamic. The poet's mind can be like a water-mirror, while his poetry captures the fleeting forms like a gushing river.

By using this metaphor, Su Shi defended his young friend as a truly enlightened person. The erudite citations and Su's taunting tone in the first paragraph of the essay suggest that the polemic stakes were high. Su Shi was not just praising Sicong, an otherwise obscure monk, but was endorsing the poetic art as a legitimate means in the pursuit of the Way. We have already examined a similar controversy in Song Confucianism, and Su Shi's apology further brings us to a controversy in the Buddhist circle.

\section{Monastic Poetry and Its Controversy}

Sicong belonged to the group of poet-monks (shiseng 詩僧) who had populated the middle ground between the secular and sacred elite since the late eighth century. These were Buddhist clerics who composed poetry in the literati mode. It is true that in the Six Dynasties, monks like Zhi Daolin 支道林 (314-366) had already started to socialise with the literati and occasionally wrote poems. Their verses, however, were limited in number, mostly short and ga atha-like. Poetry from legendary, if not fictitious, Chan monks (like Wang Fanzhi 王梵志, Hanshan 寒山 and Shide 拾得) also gained broad circulation in society in Early and Mid-Tang, but these poems were mostly vernacular. It was an alternative style to the mainstream poetry. 'Poet-monks', in contrast,

66 See Su's interlineal note in his poem “Zeng shiseng Daotong” 贈詩僧道通, sssJ, 45.2451. 
wrote in the mainstream poetic style. Their collective appearance since the Dali 大曆 period (766-779) was conspicuous both in the number of poets and in the quality and quantity of their compositions. ${ }^{67}$ Not all, but most, of them were in the Chan order, and they became active when Chan was gaining force in society.

Monastic poetry reflected a new approach of Buddhism towards language. Yao Mian 姚勉 (1216-1262) commented:

Monks in the Han Dynasty were devoted to translation; monks in the Jin were devoted to preaching; from Liang and Wei until Early Tang, monks started practising Chan, but did not yet write poetry. In Late Tang, Chan reached its prime, and monks' poetry also reached its prime. ${ }^{68}$

Before the rise of Chan, Chinese Buddhism was already a verbose religion. Monastic libraries were stacked with numerous translated sūtras, indigenous sūtras, apocrypha, treatises, commentaries, sub-commentaries, dictionaries and popular brochures, a situation that created "the uneasy presence of words in the transmission of the allegedly wordless truth". ${ }^{69}$ Chan Buddhism arose as reaction to scholasticism. It claimed legitimacy on the purported transmission of dharma when Mahākāśyapa smiled in response to Śākyamuni Buddha's raising of a flower. The Buddha was said to have declared, "Do not stand on words [but rather on]/ a separate transmission outside the teachings” 不立文字教 外別傳. ${ }^{70}$ The transmission of dharma from Bodhidharma to the first ethnically Chinese patriarch, Huike 慧可 (487-593), was based similarly on a wordless gesture. ${ }^{71}$ This peculiar way of transmission emphasises the ineffable nature of dharma, which cannot be conveyed in language (particularly not in written words) but only in the intimate performance of the enlightened being.

Yet Chan could not exile language entirely from its terrain. Its claim of superiority was based on the singular, historical gesture of the Buddha's raising a flower. To elevate itself above its competitors, historiography was needed to preserve and celebrate that single moment of the past, commemorated as ever-present. Furthermore, restricting the dharma message to wordless per-

67 See Sun Changwu 孫昌武, Chansi yu shiqing 禪思與詩情 (Beijing: Zhonghua shuju, 1997), 330.

68 Yao Mian, “Zeng Jun-shangren shixu” 贈俊上人詩序, in Xuepo ji 雪坡集, sKQQs, 1184.37.6; for further arguments on the association between the rise of Chan and the rise of monastic poetry, see Sun Changwu, Chansiyu shiqing, 339-46.

69 Gimello, "Mārga and Culture", in Paths to Liberation, 408.

70 Puji 普濟, Wudeng huiyuan 五燈會元 (Taipei: Guangwen shuju, 1971), 1.9.

71 Ibid., 1.81. 
formance would limit its audience to selected monks in numbered temples, while weakening the credibility of the Chan order in society at large. To reach out to the educated elite, they needed to establish their own canons and history. Consequently, after the rise of Chan, they immediately fed library shelves with their chosen sütras, 'recorded sayings' (yulu 語錄), 'public cases' (gong'an 公案) and 'transmission of the lamp' hagiographies (chuandenglu 傳燈錄).

Another byproduct was monastic poetry. When the Chan lineage discarded language as a tool, it soon embraced it as art. Since the late eighth century, certain monks had begun to be known as 'poet-monks' and established close associations with literati. Scholars have put forwards different explanations for the appearance of poet-monks: the general popularity of poetry in Tang society, the monks' need of lay patronage, or the secular education they had received before training as monks. ${ }^{72}$ Some monks straddled both sectors. The best-known example was Jia Dao 賈島 (779-843), who left the monastic order on the friendly advice of Han Yu. As the representative of the Late Tang poetry style, Jia Dao was painstaking in his writing, ${ }^{73}$ an attitude emulated by many poet-monks of this era. Monastic poetry from the Late Tang to Early Song was exclusively pentasyllabic, characterised by its terseness, natural imagery, and strict phonetic and vocabulary control. ${ }^{74}$ Those monastic authors readily acknowledged their "addiction to versification" (yinpi 吟癖). ${ }^{75}$ From the eighth to the eleventh century, the following were among the monks famous for their poetic compositions: Jiaoran 皎然 (720-804), Guanxiu 貫休 (832-912), Qiji 齊已 (863?-937?) and the Nine Monks in the Early Song period known as a group. Among Su Shi's monastic friends, more than a dozen were known chiefly for their poetry.

A common criticism of monastic poetry was aesthetic, namely that it had a narrow scope of vision and vocabulary. In an anecdote related by Ouyang Xiu 歐陽修 (1007-1172), a mischievous scholar once summoned nine famous poetmonks and asked each of them to write a poem without using words like mountain, water, wind, cloud, rock, star, flora or fauna. As a result, not a single

72 See Wang Xiulin 王秀林. “Wan-Tang Wudai shiseng de yinpi ji qi chengyin” 晚唐五代 詩僧的吟癖及其成因, Shoudu Shifan Daxue xuebao (zhesheban) 首都師範大學學 報 (哲社版) (2004), 5: 67-72, and Lu Yongfeng 陸永峰, “Tangdai sengshi gailun” 唐代僧 詩概論, Wenyixue yanjiu 文學遺產研究 (2002), 3: 368-78.

73 The story of him pondering between "to push" (tui 推) and “to knock” (qiao 敲) makes tuiqiao the synonym for the painstaking conceptive process. See Ruan Yue 阮閱, Shihua zonggui qianji 詩話總龜前集 (Beijing: Renmin wenxue chubanshe, 1987), 11.130-1.

74 See, e.g., Zhou Yukai, Zhongguo chanzong yu shige, 41-2.

75 See Wang Xiulin, “Wan-Tang Wudai”, 67-72. 
poem was written. ${ }^{76}$ Given their simple lifestyle, the dearth of experience and possibly limited access to a variety of books, most monks' poetry shares a homogeneous outlook of purity and simplicity. Even Su Shi admitted that. In a poem for the monk Daotong 道通, he first praised his masculine style and then commented:

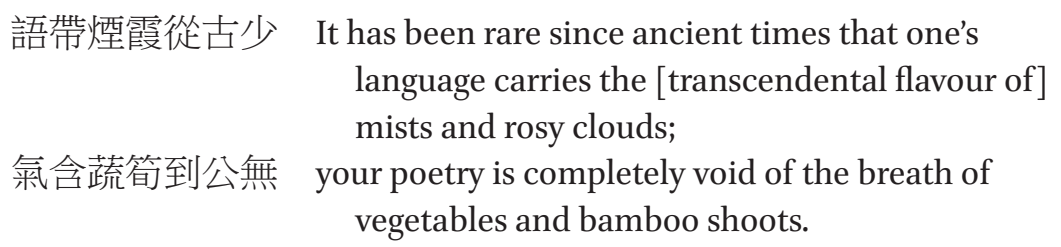

He added an interlineal note, "What I mean is that it does not have the suanxianqi 酸餡氣”, 77 literally 'the sour-stuffing-breath' of the rancid burp from a stomach accustomed to a vegetarian diet. It seems that Su Shi was praising Daotong's poetry at the expense of other monks. Henceforth, shusunqi 疏简氣 and suanxianqi became a set phrase in the criticism of conventional monastic poetry and was quoted in various Song Dynasty discourses. ${ }^{78}$ As Yuan Haowen 元好問 (1190-1257) summarises, “The poet-monks' poetry differs from literati poetry exactly for its breath of vegetables and bamboo shoots". ${ }^{79}$

Su Shi's attitude towards poet-monks therefore appears dubious. On the one hand, he liked to befriend them, but on the other, he only praised their poems when they were unlike typical monks' poetry and conformed to the literati's aesthetic standards (especially his own masculine style). Such a paradox shows the complexity of this topic.

Whether monks should write poems at all was always a point of contention. A Chan master once preached that acolytes should follow those achieved Chan masters, famous for their deeds and reticence. If, however, they "follow the man of letters to learn overstating and ornamented language", then they would sink deeply into delusion. ${ }^{80}$ Poetry is a particularly dubious kind of "ornamented language". As the sūtra warns, one transgresses this taboo due to "the karma

76 Ouyang Xiu, Shihua 詩話, in Ouyang Xiu quanji 歐陽修全集 (Beijing: Zhonghua shuju, 2001), 1951-2.

77 Su Shi, "Zeng shiseng Daotong", sssJ, 48.2451.

78 See, e.g., Ye Mengde 葉夢得, Shilin shihua 石林詩話, in Lidai shihua 歷代詩話, ed. He Wenhuan 何文煥 (Beijing: Zhonghua shuju, 1981), 425-26; Hu Zi 胡仔, Tiaoxiyuyin conghua 莒溪漁隱叢話 (Beijing: Renminwenxue chubanshe, 1962), 57.392.

Yuan Haowen, “Muan shiji xu” 木庵詩集序, Yishan xiansheng wenji 遺山先生文集, Sibu congkan (chubian) 四部叢刊 (初編) (Shanghai: Shangwu yinshuguan, n.d), 37.6a.

80 Xuetang Daoxing 雪堂道行, Xuetang Xing shiyilu 雪堂行拾遺錄, 让 no. 1576, 83.372a-b. 
of the mouth' (kouye $\square$ 業). ${ }^{81}$ Such admonition against poetry was ubiquitous in the Chan order. Anecdotally, even the famous poet-monk Jiaoran regretted his earlier infatuation with poetry, confessing, "It only disturbed my true nature! I should rather sit on my meditation couch, facing in silence a lonesome pine, a piece of cloud!" 82 The author and the audience of Jiaoran's hagiography must have expected and relished the old monk's remorse. Nevertheless, the lovely description of his meditation couch may suggest that his karma was not entirely broken.

The elite's reaction to the monks' poetry varied. Some critics gleefully celebrated the monks' writing of poetry as evidence of their conversion to Confucian values. Again according to Yao Mian, "Chan is still the proper engagement of monks. From practising Chan to practising poetry, the monks are eventually returning to our Confucianism!"83 The verb 'return' (gui 歸) suggests that “our Confucianism" (wuru 吾儒) was an order to which these monks rightfully belonged. In this view, the monks' writing of poetry revealed their longing for the civil life and invalidated their religious vow of detachment.

As a result, even sympathetic readers felt this issue to be a delicate one. For instance, Bo Juyi, in the preface to a poem addressed to a poet-monk, felt obliged to apologise:

The master's words are all upright. I therefore know that he writes for righteousness, for dharma, for the expedient wisdom, for the liberated nature, but not for poetry. ${ }^{84}$

Curiously, he justifies the monk's versification as being anything but poetry. It implied that poetry was, after all, an unworthy pursuit for the monk. One may be tempted to ask why the monk bothered to devote time and energy to the unworthy 'ornaments' at all. It was a difficult defence for Bo to maintain.

Su Shi's aesthetic hubris against the majority of monastic poetry aside, his defence for their right of versification was the strongest one. His argument may be understood as a syllogism. First, 'skilful means' are necessary for enlightenment. Second, poetry is a 'skilful means'. And third - the trickiest part - poetry is a superior means in the pursuit of enlightenment.

81 The other three kinds of transgressions of the mouth are ambiloquy, cursing and lying. See, e.g., Epitan ganlu wei lun 阿毘曇甘露味論, T no. 1553, 28.966b.

82 Fulin 福琳, “Tang Huzhou Zhushan Jiaoran zhuan” 唐湖州杼山皎然傳, in Zanning 贊寧, Gaoseng zhuan 高僧傳, T no. 2061, 50.892a.

83 Yao Mian, "Zeng Jun-shangren shixu”, 37.6.

84 Bo Juyi, “Ti Daozong Shangren shiyun bing xu” 題道宗上人十韻并序, in BoJuyi ji 白居 易集 (Beijing: Zhonghua shuju, 1979), 21.470-1. 
'Skilful means' are necessary for enlightenment. As Su Shi proposed in "Seeing off Sicong", "no student of the Way since the olden times has ever entered [dharma's] realm through emptiness". The Vimalakìrti Sütra, a Chan canon particularly popular among the literati patrons, warned that a peculiarly dangerous bondage for Buddhist practitioners is the greed for emptiness. This is called "Bodhisattva's bondage" 菩薩縛, 85 and pure meditation might expose its practitioner to this special danger. There is no easy way for man to command the instincts and impulses within himself. Instead of gazing into the engulfing emptiness, one can more dependably achieve self-oblivion through mundane, routine and concentrated works. These works are 'skilful means', set up skilfully by the Buddha to facilitate normal human practice.

Poetry is a 'skilful means'. Su Shi proposed that "poetry and dharma do not hamper each other". ${ }^{86}$ In "Seeing off Sicong", he argued that poetry, just like meditation or sütra reading, is a guesthouse on the way to enlightenment. As Zhou Yukai 周裕鍇 has noted, since Chan Buddhism proposes to seek enlightenment in the common and the quotidian, including in trivial objects and physical labour, then writing and painting could also be part of the Chan practice, insofar as they help cultivate concentrated meditativeness. ${ }^{87}$ Therefore, when translation and preaching were discarded, poetry became an alternative 'skilful means'.

Moreover, Su sees poetry as a superior means in the pursuit of enlightenment. As he argues in "Seeing off Sicong", though wisdom and concentration are both needed to acquire enlightenment, wisdom brings out concentration faster than the other way around. Art and poetry are signs of Sicong's wisdom; and if Sicong would achieve the Way, as Su Shi announces in a de facto manner, "then zither and calligraphy will both have helped, and poetry particularly so". Two more steps are needed to prove this proposal: first, even though all skilful means lead to enlightenment, there is a hierarchy among them; second, poetry is a particularly efficacious means superior to music and calligraphy.

\section{Poetry as Skilful Means}

A highly influential school of thinking on the Chinese Buddhist approach to enlightenment was Tiantai, ${ }^{88}$ to which many of Su's monk friends be-

85 The Vimalakìrti Nirdeśa Sūtra (Weimojie suoshuojing 維摩詰所說經), T no. 475, 14.545b.

86 Su Shi, “Song Canliao Shi” 送參寥師, sssJ, 17.907.

87 Zhou Yukai, Zhongguo chanzong yu shige, 39 .

88 Neal Donner, "Sudden and Gradual Intimately Conjoined: Chih-I's T'ien-tai View", in 
longed. ${ }^{89}$ The central doctrine of Tiantai was the 'twofold truth' theory, proposed by Nāgārjuna in Mūlamadhyamakakārikā (Zhonglun 中論 or Knowledge of the Middle Way). It argues that there is the worldly mundane truth and there is the truth of supreme meaning. In reality, they are both distinct and united as two views of the same truth. ${ }^{90}$ This theory was further developed by Zhiyi 智顗 (538-597), founder of the Tiantai School, into a sophisticated soteriological system. Zhiyi interpreted reality as a 'Threefold Truth', or a single unity with three integrated aspects: emptiness (kong 空), the ultimate truth; conventional existence (jia 假), the temporary existence of the phenomenal world; and the Middle (zhong 中), a simultaneous affirmation of both emptiness and conventional existence as aspects of a single integrated reality. ${ }^{91}$ Around this threefold truth, Zhiyi proposed a system of gradations towards the ultimate identity. Therefore, the teaching of 'sudden' enlightenment could be united with the 'gradual' practice. It also meant that every practitioner had to choose an individual path in a hierarchical system commensurate with their endowed capacity. ${ }^{92}$

Su Shi's reflection upon difference and identity shows the influence of the Tiantai School. For him, the teaching of non-duality was in dialectic unity with the affirmation of relative distinctions. The paths to enlightenment may include crafts, arts, physical labour or meditation. They ultimately lead to the same goal, but there are distinctions in quality, momentum and immediate results.

Sākyamuni Buddha has achieved the supreme, correct enlightenment, ${ }^{93}$ and he says, "I have gained it because of my no-gaining". ${ }^{4}$ Śāiputra ${ }^{95}$ has achieved the arhat's enlightenment, and he also says, "I have gained it because of my no-gaining" ${ }^{\prime 6}$ Are the Buddha and Saariputra so much the

Sudden and Gradual: Approaches to Enlightenment in Chinese Thought, ed. Peter N. Gregory (Honolulu: University of Hawaii Press, 1987), 202-3.

89 Grant, Mount Lu Revisited, 23.

9o Paul L. Swanson, Foundations of T'ien-T'ai Philosophy: the Flowering of the Two Truths Theory in Chinese Buddhism (Berkley: Asian Humanities Press, 1989), 1-2.

91 Ibid., 6.

92 Donner, "Sudden and Gradual", 203-21.

93 “The supreme, correct enlightenment” 阿耨多羅三萝三菩提 is the transliteration of the Sanskrit term 'anuttarā-samyak-sambodhi'. Anuttarā means 'unsurpassed', samyak means 'correct', and sambodhi means 'enlightenment' or 'awakening'.

Jingang boruoboluomi jing 金剛般若波羅蜜經, T no. 235, 8.749c, 751c.

95 The first of the ten disciples of Śākyamuni Buddha.

96 The Vimalakìrti Sūtra, T no. $475,14.548 \mathrm{c}$. 
same? I would say: not only Saariputra, but even the humble craftsmen of a hundred trades, like catching cicadas, ${ }^{97}$ single-minded hook-making smithcraft, ${ }^{98}$ observing pigs' feet ${ }^{99}$ and painting walls, ${ }^{100}$ none of them is different [from the Buddha]. Talking about the greatness or pettiness in their achievement of the Way, even a great Bodhisattva facing Sākyamuni Buddha is just like an abyss facing the sky. In terms of gaining because of no-gaining, however, even catching cicadas, hook-making, observing pigs' feet and painting walls - these craftsmen are all not different from the Buddha. [...] Therefore the Diamond Sūtra declares: all the wise and sagacious regard non-being as dharma; however, there are distinctions in it.

\section{如來得阿耨多羅三䔔三菩提, 日：“以無所得故而得。”舍利弗 得阿羅漢道, 亦日：“以無所得故而得。”如來與舍利弗若是同 乎？日：何獨舍利弗，至于百工賤技，承蜩意鉤，履稀畫墁， 未有不同者也。論道之大小, 雖至於大菩薩, 其視如來, 猶若 天淵然，及其以無所得故而得，則承蜩意鉤，履狶畫墁，未有 不與如來同者也。 $[. .$.$] 故《金剛經》日：一切賢圣, 皆以無為$ 法, 而有差別。101}

This account was written in 1095 during Su Shi's Huizhou exile. The dialectics of the Buddha's "gaining because of no-gaining" comes from the Diamond Sūtra, and in the case of Śāriputra, from the Vimalakìrti Sūtra. In the Diamond Sūtra, Subhūti asked the Buddha, "The World-honoured One! You have gained the supreme, correct enlightenment; does it mean you have gained nothing?" The Buddha approved his insight and declared that his dharma was a great unity in which there was no self, no human and no sentient beings. In the Vimalakìrti Sūtra, a goddess overpowered Śāriputra by virtue of her insight of the dharma. Sāriputra thought her female form was inferior to the male form, a thought which revealed his attachment to the form. The goddess asked if Sāriputra gained his arhat's enlightenment because of his no-gaining. He con-

97 See zZJS, 19.639-40.

98 See the story of the old hook maker in the Zhuangzi; zZJs, 22.760-1.

99 In the "Zhibeiyou" chapter, Master Zhuang explained that, just as an experienced market supervisor knew the fatness of pigs from examining their feet, the Way manifested itself most tellingly in the basest objects. See zzJs, 22.749-50.

100 This is a metaphor borrowed from Mencius 6.4, not for its original meaning but solely for the sake of parallelism with "observing the pigs' feet".

101 Su Shi, “Qianzhou Chongqing Chanyuan xin jingzang ji” 虔州崇慶禪院新經藏記, sswJ, 12.390-1. 
curred. Then she declared that it was the same with all the Buddhas and Bodhisattvas.

Both references suggest that distinctions are illusory. As Su Shi further points out, the distinction among various crafts, or between a craftsman and a bodhisattva, is only that of quantity, while their distinction with the Buddha is of quality. The former kind of quantitative distinction is made relative and dismissed as negligible. Push this logic to an extreme and every art or craft would be seen as essentially the same. Indeed, all distinctions should then be abolished - qualitative or quantitative - since when one calls distinction 'distinction', one is in reality already making a distinction.

Yet, in the end, Su Shi abruptly reaffirms the distinctions. The original context of the quotation explains why. As the Buddha points out to Subhūti, the servants of the Buddha all regard emptiness as dharma, but they approach and promote dharma in different ways (for instance donation, holding precept or preaching). These varying approaches do create differences in terms of immediate results. Elsewhere, Su Shi provides another analogy for the theory of relative distinctions within a grand unity:

My dharma is not like that - it is neither a thousand nor just one.

It is like hundreds or thousands of lights, shining together in a single chamber.

Though each shines through the whole space, it does not infringe on or mix with another.

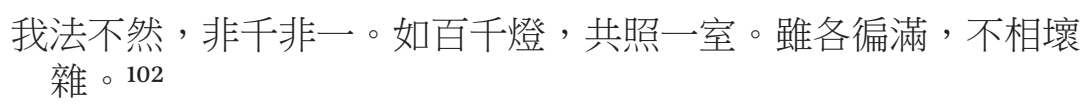

This inscription was composed in the first month of 1101, shortly before Su Shi's death. Its lamp metaphor is an apt comment on the account quoted above. The reaffirmed distinction is no longer the initial distinction, but a distinction made in the awareness of its illusory nature.

Arthur Danto, a contemporary art theorist, once quoted the well-known 'public case' of the Southern Song Chan master, Qingyuan Weixin 青原惟信, to expound his theory of art. Qingyuan declared that there were three stages in his understanding of the dharma: the first stage, seeing mountain as mountain and water as water; the second stage, seeing mountain not as mountain and water not as water; and the third stage, seeing mountain still as mountain and

102 Su Shi, “Nan’an-jun Changle-yuan xin zuo jingzang ming” 南安軍常樂院新作經藏銘, sswJ, 19.580. 
water still as water. ${ }^{103}$ According to Danto, the last stage is an analogy of aesthetic resemblance. Just like saying 'the black paint is black paint', while knowing that it is identified with something else, this 'is' implies 'is not' at the same time. ${ }^{104}$ Similarly, in the eyes of an enlightened one, the distinction among the means simultaneously is a distinction and is not a distinction.

Su Shi thought the skilful means to be not only distinctive but also hierarchical. As Susan Bush has noted, Su Shi established a hierarchy of arts in which painting was ranked lower than calligraphy, and calligraphy lower than literature. She regards it a matter of the social usefulness of respective skills. ${ }^{105}$ It is true that poetry traditionally enjoyed the highest cultural prestige and, since the civil examination system was established in the seventh century, had become a highway to fame and riches. Su's hierarchy, however, might also be informed by philosophical speculations. Su Shi argued that the supremacy of poetry to other arts came foremost from its minimum dependence on materiality. Unlike calligraphy and painting, reliant on the presence of brush and paper, poetry appeared to be a purer mental form. It could be composed mentally and transmitted orally, independent of external 'things'.

Su Shi constantly admonished painters and calligraphers to be wary of their dependence on the materiality of their arts, lest they be 'enslaved' by things. His warning resonated with a persistent theme in Chinese intellectual history. As Xunzi declares, “A gentleman enslaves things (yiwu 役物); a little-man is enslaved by things". ${ }^{106}$ Similarly, Buddhism proposes to 'transform things' (zhuanwu 轉物), instead of 'being transformed by things'. ${ }^{107}$ Such admonitions shared the same philosophical caution on ownership. Modern capitalism regards one's material possessions as the extension of one's self, ergo property rights are inalienable, and the accumulation of wealth equivalent to the increase of individual power. The intellectual traditions that Su Shi inherited, however, regard the concentration and tranquillity of one's subjective self to be the sole source of one's power. Yet, unlike Buddhists, Xunzi certainly did not denounce ownership per se. Social, economic and political status has always been essential aspects that define the genteel class. Rather, the gentleman can continue to possess things, but his self is not dispersed into his possessions;

\footnotetext{
103 Xu Chuandenglu 續傳燈錄, T no. 2077, 51.614b-c.

104 Danto, "The Artworld", 37-40.

105 Bush, Chinese Literati, 12.

106 See Xunzi, 2.5

107 "To transform things" is used in many Buddhist texts. Its idea might come from Seng Zhao's 僧肇 “Discourse on the Unreal-Void” 不真空論, though he did not explicitly use this term. See Seng Zhao, Zhao lun 肇論, T no. 1858, 45.152a-b.
} 
thus he is undisturbed by his material losses or gains. Su Shi's 'non-attachment' theory largely followed this argument. His theory, summed up in Ronald Egan's terms, was "not allowing oneself to become attached to things or [become] possessive about them". ${ }^{108}$ To do so, one's mind must be kept constantly tranquil and empty - the same 'water-mirror' mind which, in artistic creativity, responds without disturbing itself. Not being 'enslaved by things', therefore, is prerequisite to spontaneous creation.

As Su Shi understood it, among the three genteel arts, poetry promised its practitioner the least degree of attachment to materiality. When writing under request for a newly built painting studio, Su Shi argued that, "a gentleman's mind could reside (yuyi 寓意) in things, but should not linger (liuyi 留意) on things". He then suggested that calligraphy and painting were especially dangerous 'things' because, being such noble delights, they might enchant even the best minds into obsessive possession and collection. ${ }^{109}$ This danger posed a threat to connoisseurs, collectors and students alike. During the Song, without modern galleries or picture books, a student of art would have had to acquire a number of originals or handmade copies of exemplary artwork. Besides, a large amount of materials were needed just for practice. Su Shi once joked with a calligrapher, "A proverb from my hometown Sichuan says, 'learning calligraphy costs paper, [just like] learning medicine costs people"'.110 The study of calligraphy and painting thus entailed consumption. Su Shi entertained the idea that real art should get riddance of materiality. As the Jin recluse Tao Qian suggested, the best zither had no strings; Su Shi, in addition, would like to borrow this "string-less zither" and fiddle his "finger-less play". ${ }^{111}$ In this regard, poetry's relative immateriality guarantees a higher degree of spontaneity.

\section{Coda}

Su Shi's assertion that poetry was a quintessential skilful means to enlightenment combined a vast range of intellectual sources. Approaching the end of this chapter, we return full circle to the questions asked in the beginning

\footnotetext{
108 Egan, Word, Image, and Deed, 157.

109 Su Shi, “Baohui Tang ji” 寶繪堂記, $s s w J, 11.356$.

110 Su Shi, “Mobao Tang ji” 墨寶堂記, ssWJ, 11.358.

111 On Tao Qian's string-less zither, see his biography in Fang Xuanling 房玄齡, Jinshu 晉書 (Beijing: Zhonghua shuju, 1974), 64.2463. For Su Shi's proposal: "Let me borrow your string-less zither,/ and apply my finger-less play” 借君無弦琴, 寓我非指彈, see “He Tao Dongfang you yishi” 和陶東方有一土, sssJ, 41.2265-6.
} 
concerning Su Shi's defence of Daoqian's poetry: even if poetry could help the student of the Way acquire a mind like a clear mirror, why should this 'clear mirror' write at all, and commit the transient traces of nature into reified words?

Writing, even the most spontaneous kind, cannot avoid reification. The German playwright Georg Büchner (1813-1837) once depicted a beautiful scene of two girls sitting in an Alpine valley. In the voice of the poet Jacob Lenz, he regrets:

The most beautiful, most sensitive pictures of the Old German school would hardly have done justice to it. It would sometimes be good to be the head of Medusa so as to be able to turn such an image into stone and to call everyone to come and look. They stood up, the image was broken, but as they descended they created another picture between the rocks. The most beautiful pictures, the most soaring sounds form themselves and dissolve. Only one thing remains: an infinite beauty passing from one form to another, for ever changing, for ever renewing itself. ${ }^{112}$

The analogy of art to a Medusa's head implies that nature can be turned into art only through its petrification. The true forms in nature keep transforming. But poetry bestows its instantaneous, fictive death and promises an aesthetic immortality.

In a certain sense, the artist lives his afterlife in the eyes and ears of the world through his works. Fear consequently rises over the decay of his chosen medium. Su Shi speculated on this issue through the voice of another:

Someone once told me: every 'thing' will come to its end, and those counting upon their material forms for durability will particularly not last long. Even things as solid as metal and stone will soon change and decay. As for political and literary accomplishments, they may last longer, due to the fact they will be remembered by generations and set examples for the future.

或以謂余, 凡有物必歸於盡, 而恃形以為固者, 尤不可長, 雖 金石之堅, 俄而變壞, 至於功名文章, 其傳世垂後, 乃為 差久。113

Georg Büchner, Lenz (1835), in The Complete Plays, trans. Michael Patterson (New York: Methuen, 1987), 257 .

113 Su Shi, “Momiao Ting ji” 墨妙亭記, sswJ, 11.354-5. 
This wise man articulates Su Shi's fear of decay. As Su declared in a colophon on a painting, "The traces of brush and ink are dependent on material forms, which must also decay". 114 The only 'non-decays' are gongming wenzhang 功名 文章 or political and literary accomplishments. His notion of literary immortality is apparently informed by a passage in the Zuozhuan 左傳, where the Lu minister, Shusun Bao 叔孫豹, suggested three kinds of 'non-decays' (buxiu 不 朽): the establishment of virtue (lide 立德), of successful service (ligong 立功) and of words (liyan 立言). ${ }^{115} \mathrm{Su}$ Shi appeared not to have aspired for the establishment of sagely virtue. He did once aspire to political accomplishment, but in 1071, when he wrote the essay cited above, he was already in conflict with Wang Anshi over the New Policies ${ }^{116}$ and would soon be removed from the capital. What he felt most secure about achieving at that moment could only be the establishment of words.

Poetry for Su Shi was simultaneously a 'skilful means' in the pursuit of enlightenment - understanding the impermanence of the phenomenal world and a passport to immortality. These two seemingly conflicting pursuits may just reveal the paradoxical nature of language. Poetry distinguishes itself from other arts as being less attached to materiality. Moreover, poetry breaks away from quotidian syntax and captures the ineffable through imagery. The reading of poetry approximates the immediacy of the wordless dharma transmission. But, at the same time, language is a manmade, semiotic system, a part of our phenomenal world. The ultimate truth, if there is such a thing, resists representation. The poetry of spontaneity is oxymoronic because it reflects the desire of language to go against itself. It wants to captivate the boundlessness, to voice the wordless and to immortalise the temporary. The poet desires to become a perfect mirror, but the moment he puts the transitive forms into words, the 'gushing river' is frozen. All he has on the paper are reified symbols.

The pursuit of enlightenment, in this analysis, becomes a pretext. The poet uses his art to immortalise his traces of living in a historical time and space. If

114 Su Shi, “Ti Bizhen-tu” 題筆陣圖, sswJ, 69.2170. Ronald Egan has also noted this colophon, but it leads him to a different conclusion: "[...] for Su Shi [...] the practice of not collecting calligraphy is just an amusement"; cf. Egan, "Ou-yang Hsiu and Su Shih on Calligraphy", Harvard Journal of Asiatic Studies (1989), 49.2: 412. In my opinion, Egan has taken Su Shi's claim ("calligraphy is finer than playing chess") too literally. Dismissing the significance of calligraphy might well be a way to relieve him of the anxiety over the decay of material forms that bear his 'traces' of existence.

115 Chunqiu Zuozhuan zhengyi 春秋左傳正義 [Xiang 24], ssJzs, 27.277.

116 On this reform, see, e.g., Liu, James T. C., Reform in Sung China: Wang An-shih (1021-1086) and His New Policies (Cambridge, Mass.: Harvard University Press, 1959); Qi Xia 漆俠, Wang Anshi bianfa 王安石變法 (Shijiazhuang: Hebei renmin chubanshe, 2001). 
the pursuit of enlightenment reflects a 'death instinct' - a longing for an abrupt departure from the illusory life - then writing poetry and making art reflects a 'life instinct' - a longing for permanence in the human world. Along the way of language, the means has become the goal. Moreover, to realise this goal, the reader must participate in the recreation process. It also means that only when the reader recognises his own face in the mirror of the poet, will the poet's living sparks be reignited. Or rather, the reader's recognition of the self joins forces with the poet's cognition of the world to create the 'perfect mirror'. 


\section{The Making of Spontaneity in a Work of Art}

Pingdan 平淡, or 'the even and plain', is a tangible ideal in Song Dynasty art. Even a casual visitor to a Chinese art museum cannot fail to note that the exuberance of colour and vivid forms of life in Tang Dynasty artwork quickly recede to pale green $\mathrm{Ru}$ or snow-white Ding porcelains, recluses in abstract outlines and half hidden in a vast landscape, and calligraphic strokes that are almost eccentric. In general, if not always, Song art seems to represent someone coming of age and becoming self-conscious, no longer focused on sensual forms but seeking to discover the rules behind and beyond the phenomenal world. As a result, art acquired the taste for pingdan - once a pejorative word, in the Song it was found to represent the ideal of concealment or the riches of substance beneath a modest surface. Mastering a pingdan surface was seen as the highest achievement for poetry, ${ }^{1}$ calligraphy, ${ }^{2}$ and painting ${ }^{3}$ alike.

On exactly what was meant by pingdan, opinions differ. Zhu Xi regarded it as the simple (if cultivated) absence of artistic design; a novice poet should begin by emulating the pingdan style of ancient poets lest that his style became impure. ${ }^{4}$ In contrast, Su Shi saw it as the understated appearance beneath which there hid ultimate skill and strength; a matured poet would eventually 'return' to this state. As he advised his nephew in a letter:

As for writing in general, when you are young, you should make its aura lofty and steep, its colour vivid and splendid. When you age and mature, eventually your writing will achieve plainness. It is in fact not plainness, but ultimate splendour.

\section{凡文字, 少小時須令氣象崢橴, 采色絢爛, 漸老漸熟乃造平 淡, 其實不是平淡, 絢爛之極也。 5}

1 See Yoshikawa Kōjirō 吉川幸次郎, An Introduction to Sung Poetry, trans. Burton Watson (Cambridge, Mass.: Harvard University Press, 1967), 35-8, where this term is translated as "calmness and ease".

2 See Sturman, $\mathrm{Mi} F u, 140-1$, where this term is translated as "even and light".

3 See Cahill, "Confucian Elements", 98-9, where this term is glossed as "the virtue of concealment".

4 Yang, "Zhu Xi as Poet".

5 Su Shi, “Yu Erlang zhi yishou” 與二郎姪一首, sswJ, yiwen 佚文 4.2523. 
In other words, the appearance of naturalness was made by the highest craft, the kind that was capable of restraining itself. Su Shi followed his own advice by studying the limpid poetry of Tao Qian in the last decade of his life. What he found valuable in Tao was a 'withered plainness' (kudan 枯澹), defined as "withered outside and saturated inside; seemingly plain but rich in taste".

Charles Yim-tze Kwong argues that in understanding Tao Qian's simplicity one should avoid two opposite assumptions: that simplicity means the absence of artistic design; and, antithetically, that all impressions of simplicity are fabricated. According to him, Tao's simplicity is that of "a natural genius eminently capable of writing spontaneously under the hold of inspiration".7 Su Shi's understanding differed from any of the above assumptions. For him, simplicity or 'plainness' certainly did not mean the lack of design, nor was it purely fabricated. And, although his 'gushing river' metaphor bears resemblance to Kwong's 'natural genius' theory, this chapter will examine Su Shi's critical discourses on artistic composition and argue that he more often took a 'gradualist' approach to artistic excellence. For Su Shi, the appearance of spontaneity required deliberate practice as well as induced oblivion at the moment of composition. Ultimately, as he suggested in the "Record of Snow Hall" (Xuetangji 雪堂記), the artist is lodged in a world of resemblance between the phenomenal and the void - a sanctuary for the dislocated. Since a 'spontaneous' work must be the unadorned articulation of the artist's nature, the work becomes the artist's substantiation. Furthermore, since Su understood human nature as imperfectible, the appearance of spontaneity would remain technically imperfect and individualistic, an empirical feature observed in Song Dynasty art.

\section{The Emphasis on Practice}

Su Shi's writing on art often cites the Zhuangzi, as well as Buddhist sources. In the Zhuangzi, humble craftsmen often display the essence of the Way through their excellence in various crafts. Their attention is focused and their movements economic, reduced to exactly what is required for the perfect execution of the task. For A.C. Graham, a Zhuangzian craftsman is "spontaneous from the very center of his being", and his motions "derive not from himself but from

6 Su Shi, “Ping Han Liu shi”, 評韓柳詩, sswJ, 67.2109-10.

7 Charles Yim-tze Kwong, "Naturalness and Authenticity: The Poetry of Tao Qian", Chinese Literature: Essays, Articles, Reviews (CLEAR) (1989), 11: 63. 
Heaven working through him". ${ }^{8}$ As noted in the Introduction, in Chinese theories of art, a Zhuangzian craftsman has come to represent an archetypical artist who realises the pattern of Heaven through the words and works of man.

To reach that degree of spontaneity, the craftsman needs to undergo long, repeated and concentrated practice. In modern neuroscientific parlance, it is through practice that the neurons for a task become increasingly wired together. Once the neurons controlling one step of the task are stimulated, those for the next step are automatically triggered. The practitioner therefore can execute a practised task almost unthinkingly, sparing his attention for other purposes. It is the brain's economic principle. ${ }^{9}$ Yet, building that level of spontaneity requires time and repetition. If Su Shi's notion of apprenticeship was Zhuangzian, he could not at the same time have been a 'suddenist' in terms of achieving Buddhist enlightenment or artistic excellence.

The controversy between 'the sudden' (dun 頓) and 'the gradual' (jian 漸) approaches to enlightenment has been a constant point of tension in Chinese Buddhism. The difference between the two approaches lies not only in the speed of enlightening but also, and more importantly, in the efficacy of 'skilful means'. A strict 'sudden' approach regards enlightenment as a completely internal process, so it denies the efficacy of any external force like reified teaching or ritualised practices. ${ }^{10}$ Richard J. Lynn, citing Su Shi's poem to Daoqian that compares the monk to a water-mirror, argues that

although [Su Shi] does not seem to have ever explicitly formulated a 'sudden' approach to poetic success or 'enlightenment,' the many references to freedom and spontaneity in his writings indicate that he surely would have been in the 'sudden' camp if he had to choose sides. ${ }^{11}$

8 Graham, Reason and Spontaneity, 186.

9 For popular neuroscience literature on this topic, see, e.g., Malcolm Gladwell, Blink; Norman Doidge, The Brain That Changes Itself: Stories of Personal Triumph from the Frontiers of Brain Science (New York: Viking Press, 2007); and Malcolm Gladwell, Outliers: the Story of Success (New York: Little, Brown, and Company, 2008). From this scientific point of view, however, there is nothing mysterious about the Zhuangzian craftsmen. The tasks could be as simple as driving or as complicated as playing the piano.

The reality of religious practice was certainly much more complex than the polarised terms suggest, and teachings in many schools were nuanced combinations of both approaches. For more on this controversy, see essays collected in Gregory, ed., Sudden and Gradual and Buswell and Gimello, eds., Paths to Liberation. 
Our examination of the mirror metaphor in the previous chapter, however, suggests that Su Shi never advocated the redundancy of 'skilful means'. Instead, his exhortation of Sicong to progress through steps suggests rather a gradualist approach, an observation consistent with other scholars' discussion on Su Shi's Buddhist thoughts. ${ }^{12}$

Yet Su Shi did seem to have advocated 'not-learning' (buxue 不學) and 'having-no-models' (wufa 無法) in some poems and essays. He boasted, for instance, in a poem addressed to Su Che:

$\begin{array}{ll}\text { 吾雖不善書 } & \text { Although I am not good at calligraphy, } \\ \text { 曉書莫如我 } & \text { no one knows it better than I do. } \\ \text { 苟能通其意 } & \text { Once you understand the idea of it, } \\ \text { 常謂不學可 } & \text { as I often say, it is fine to learn no more. }{ }^{13}\end{array}$

Close reading, however, shows that Su Shi's proposals were conditioned by their contexts and were usually ironic or self-deprecating. They were not meant to be taken literally. In actual fact, this poem was a response to $\mathrm{Su}$ Che's, which exalted him, "You have mastered the style of whomever you learn from", and then proceeded to compare Su Shi's various styles to famous calligraphers of the past. ${ }^{14}$ Understood in this dialogic context, Su Shi's jovial reply was an attempt to show his humility, as he declined to be ranked among the great. By declaring that he had not learned, he staged himself as a mere connoisseur.

Su Shi often wears a mask of naivety in his social poetry. He speaks through the persona in another poem, which ostentatiously proposes 'having-nomodels'.

人生識字憂患始 All anxieties and troubles in life start with knowing characters;

姓名粗記可以休 it is enough to memorise roughly how to write our names.

何用草書誇神速 Why even boast about the vivacity and swiftness of your cursive script?

See, e.g., Grant, Mount Lu Revisited, 100-1; Jin Shengyang 金生楊, Su shi Yi zhuan yanjiu 《蘇氏易傳》研究 (Chengdu: Bashu chubanshe, 2002), 302-8; Yang Cunchang 楊存昌, Daojia sixiang yu Su Shi meixue 道家思想與蘇軾美學 (Jinan: Jinan chubanshe, 2003), 104-11.

14 Su Che, “Zizhan jishi Qiyang shiwu bei” 子瞻寄示岐陽十五碑, in Su Che ji, 1.19. 
開卷惝怳令人愁

君於此藝亦云至 堆牆敗筆如山丘 興來一揮百紙盡

駿馬修忽踏九州

When I unfold your scroll, I am at an utter loss and so puzzled!

[...]

You, sir, could also be called supreme in this art; worn-out brushes pile up by the wall like a hill.

When inspired, you complete a hundred sheets by a wave of the wrist,

like fine steeds' swiftly galloping over the Nine Provinces.

我書意造本無法 My calligraphy, however, is a mind-craft, following no models;

點畫信手煩推求 I randomly dot and stroke without taking care. 胡為議論獨見假

隻字片紙皆藏收 不減鍾張君自足

下方羅趙我亦優 不須臨池更苦學 完取絹素充念裯

But why does the public hold me in such a high opinion, and collect every character that I write on a tiny sheet? You, sir, are no inferior to Zhong or Zhang, ${ }^{15}$ sufficient in yourself;

on a lower rank, I am like Luo and Zhao, ${ }^{16}$ also not bad. I have no need of painstaking practice by the pond; ${ }^{17}$ and I can keep all the white silk for my bed linen. ${ }^{18}$

This poem was requested by the calligrapher Shi Cangshu 石蒼舒 to decorate his Drunken Ink Studio (Zuimotang 醉墨堂). The first line refers to the story of Xiang Yu 項羽 (232-202 BCE). According to Shiji 史記 (Records of the Grand Historian), when Xiang Yu was a child, his uncle tried to teach him to write to no avail. The berated Xiang Yu replied that knowing how to write his name was

15 Zhong You 鍾㨻 (151-230) and Zhang Zhi 張芝 (?-192), famous calligraphers in the cursive script style.

16 According to Wang Wengao's 王文誥 commentary, it refers to Luo Shujing 羅叔景 and Zhao Yuansi 趙元嗣, Zhang Zhi's contemporary who enjoyed certain popularity then. Zhang Zhi joked that although he could not be compared to earlier greats, he was certainly good enough to surpass Luo and Zhao; see sssJ, 6.236.

It refers also to a story, concerning Zhang Zhi, which said that all the newly woven silk and cloth in his family must first be used for Zhang's practice of calligraphy before being dyed. He practised so hard by the pond that the water in the pond eventually turned black. Later on, the same 'ink pond' story was said to refer to Wang Xizhi 王羲之 (303-61); see Zeng Gong 曾琗, “Mochi ji” 墨池記, in Zeng Gong ji 曾鞏集 (Beijing: Zhonghua shuju, 1998), 19.279-80.

18 Su Shi, “Shi Cangshu Zuimo tang” 石蒼舒醉墨堂, sssJ, 6.235-6. 
enough; he would rather save the time to learn the art of war. ${ }^{19}$ Unlike Xiang $\mathrm{Yu}$, Shi Cangshu was a calligrapher who enjoyed the reputation as someone who had acquired the essence of the cursive script style. In Su Shi's discourse on art, this highly abstract style exemplifies the ideal of 'spontaneity'. Su's poetic persona assumes a candid voice, complaining that Shi Cangshu's calligraphy is too hard for him. Shi's pile of used brushes shows that his seeming spontaneity is achieved through diligent practice. In contrast, Su claims to abide by no models or rules. He then feigns innocent surprise at his own popularity. If Shi is comparable to Zhong You 鍾䋣 (151-230) and Zhang Zhi 張芝 $(?-192)$, then he would be somewhat inferior, but still adequate. Being content with this lower position, he says, he can spare a clean pond and white linen from practice.

Su Shi's tone is casual. Poetry sometimes collapses into prose and colloquialism. Jovial hyperbole creates a sense of intimacy so that this poem reads like drunken talk, stylistically representing the studio's name, 'Drunken Ink'. Presumably, Shi Cangshu drank copiously, a common vice among cursive-style calligraphers to help them reach the subconscious state of creation. The significance of alcohol will be discussed later.

Su's poetic persona maintains an edge of irony with the actual person. The open mockery of intellectualism is also self-mockery, as he had long surpassed the 'necessary' level of literacy. Again, irony could mask authentic humility. As this was a social poem written for Shi Cangshu's studio, it is implausible to imagine that Su Shi was basking in his effortless popularity while mocking Shi Cangshu's diligence as futile. Moreover, as this poem has alluded, virtually all the major calligraphers were associated with stories of diligent practice, such as dyeing a whole pond black from washing brushes or wearing out a pile of brushes. Admitting that one had not practised enough was a way to acknowledge inferiority. Su Shi also uses the term "mind-craft" (yizao 意造) ${ }^{20}$ in an essay exhorting learning and practice, using the example of the culinary art. Su observes that if two men cook a dish or brew wine with the same ingredients, under the same conditions and according to the same recipe, the outcomes could still be drastically different. It follows that study does not guarantee excellence; but if one discards learning, abides by "no rule" and depends on his "mind-craft" alone, the result is usually unpalatable. ${ }^{21}$ This and many other instances suggest that Su Shi never denounced learning. Nor did he himself

\footnotetext{
19 Sima Qian, Shiji, 7.295.

20 Not to be confused with another term, 'craftsmanship of the mind' (yijiang 意匠), used often to describe marvellous artwork which is seemingly not of human crafts.

21 Su Shi, “Yanguan Dabei ge ji” 鹽官大悲閣記, sswJ, 12.386-8.
} 
abandon calligraphic practices. Quite tellingly, Su Che praised him for having grasped the essence of earlier masters through learning. As Huang Tingjian remarked, when Su Shi was young he learned the calligraphic styles of Wang Xizhi 王羲之 (303-361), Xu Hao 徐浩 (703-782) and Liu Gongquan 柳公權 (778-865); and, when older, from Li Yong 李茞 (678-747), Yan Zhenqing 顏真 卿 (709-785) and Yang Ningshi 楊凝式 (873-954). ${ }^{22}$ Once, Huang found in Su Shi's studio practice sheets in the styles of Yu Shinan 虞世南 (558-638) and Chu Suiliang 褚遂良 (596-659), among others, though he was not fond of their styles any more. ${ }^{23}$ In the eyes of his admirers, Su Shi appeared as an avid learner of previous models.

Su Shi has similarly emphasised the importance of practice for the study of painting. In the following essay on his cousin Wen Tong's 文同 (1018-1079) bamboo painting, Su Shi first recounts Wen's painting theory, which is to thoroughly study the form of bamboo and then to visualise "the complete bamboo in the breast" (xiongyou chengzhu 胸有成竹). With this mental image ready, the painter should execute it onto paper in swiftness and spontaneity. But, as Su cautions, knowing does not guarantee doing:

This is what Yuke [aka. Wen Tong] instructed me. I cannot do this, though I recognise in my mind how it works. ${ }^{24}$ Now, what is recognised in the mind could not be performed as such - the reason for this situation is that the inner and the outer are not in accord, and the mind and the hands do not correspond. It is the failure from not practising enough! [...] Ziyou [aka. Su Che] does not paint, so he gets only the idea of it. As for me, I have acquired not only the idea, but also the method!

與可之教予如此。予不能然也, 而心識其所以然。夫既心識其 所以然而不能然者, 内外不一, 心手不相應, 不學之過也。[...]

See Huang Tingjian, “Ba Dongpo moji” 跋東坡墨蹟, in Huang Tingjian quanji, zhengji 28.774-5.

See Huang Tingjian, “Ba Dongpo 'Xu Yinghuang shi tie” 跋東坡敘英皇事帖, in ibid., zhengji 28.773 .

24 Michael A. Fuller, in his insightful study of the issue of 'immediacy' which my inquiry has otherwise benefited from, translates this line as, "Though I knew the nature of bamboo, I could not convey it to paper"; see Fuller, "Pursuing the Complete Bamboo in the Breast: Reflections on a Classical Chinese Image for Immediacy”, Harvard Journal of Asiatic Studies (1993), 10. The difference between our translations is crucial. I disagree with Fuller's translation, since suoyiran 所以然 (literally 'that-by-which-it-is-so') simply cannot be understood as "the nature of bamboo". Rather, it refers to the process 'that-by-which' the bamboo should be painted. 
子由未嘗畫也, 故得其意而已。若予者, 豈獨得其意, 并得其 法。25

Again, Su Shi emphasises that spontaneity in artistic creation is based upon study and practice. Shi is sure that he has still surpassed Che, because Che "gets only the idea". This statement contradicts his boast made in the previously cited poem to Che, namely, "Once you understand the idea of it,/ as I often say, it is fine to learn no more".

Su Shi, however, also remarks that practice alone does not guarantee artistic excellence. On the path of cultivation towards enlightenment, when does 'spontaneity' happen? As Su argues, degrees of spontaneity can be achieved at the moment of oblivion in the process of creation.

\section{Oblivion as a Form of Liberation}

Students of art practise diligently to internalise the rules and craft of their trade but, at a certain point, they may find that their conscious control has become the greatest encumbrance for truly excellent performance. This is the moment when a student finds that, in Buddhist terms, "the way of language is severed, and all ground disappears wherever the mind goes” 言語道斷心行處 滅. ${ }^{26}$ This is the point where one is separated from the true dharma's realm by a gaping abyss. In order to cross the abyss and attain enlightenment, one must discard all 'skilful means'.

Su Shi proposes that the actual internalisation happens only when the practitioner forgets about his art as well as his pursuit of perfection. The moment of spontaneity comes abruptly when he realises that the truly enslaving principle is his inner submission to his desire, even though the desired object is transcendence. He compares the pursuit of the Way to acquiring a native tongue or learning to write:

Let me deduce what I do not know from what I do know. When a baby is born, it will be guided to speak; when he grows up, he will be taught to write. He must practise his tongue to the extent of forgetting the articulation of sounds, and only then will he be able to speak; he must practise his hand to the extent of forgetting the handling of the brush, and only

\footnotetext{
25 Su Shi, “Wen Yuke hua Yundang Gu yanzhu ji” 文與可畫筫䈏谷偃竹記, sswJ, 11.365.

26 Seng Zhao 僧肇, Zhao Lun 肇論, T no. 1858, 45.157c, and broadly quoted in later Buddhist works.
} 
then will he be able to write. This is what I know! If his tongue does not forget about its own sound, then its utterances can hardly be linked into a significant pattern; if his hand does not forget about the brush, then his written characters can hardly become precise or complete. When he reaches the supreme state of oblivion, he would be able to employ his figure, his facial expression, his mind and his craft to reciprocate the transformation of ten thousand things, in a seeming trance, without being aware of it. In the eyes of those uninitiated, would not his divine intelligence and wondrous achievement appear as transcendent as those of the Buddha?

\section{以吾之所知, 推至其所不知。嬰兒生而導之言, 稍長而教之 書, 口必至於忘聲而後能言, 手必至於忘筆而後能書, 此吾之 所知也。口不能忘聲, 則語言難於屬文; 手不能忘筆, 則字畫 難於刻周。及其相忘之至也, 則形容心術, 酧酢萬物之變, 忽 然而不自知也。自不能者而觀之, 其神智妙達, 不既超然與如 來同乎！27}

Su Shi proposes to learn one's mother tongue, as well as calligraphy, by first internalising and then forgetting manmade rules. "Forgetting the articulation of sounds" suggests that we must lose the conscious control over the sounds of the words we are uttering. Otherwise we will be gagged by self-consciousness, unable to speak fluently or coherently, and only dwelling upon the production of split notes of sound instead of pronouncing whole words or sentences. Similarly, a calligrapher would not be able to handle his brush if he focused on every movement of his wrist. Both kinds of learning are based on natural faculties. Speaking and writing capacities might be biologically based, but articulating speech or writing in calligraphy is not an innate skill. These skills require conscious teaching and learning. Rules, artificial as they are, are necessary to realise one's natural potential. A child learns to speak his mother tongue through a continued process of modifying the patterns of his linguistic behaviour. When the vocabulary and linguistic rules of the mother tongue become his second nature, he will eventually begin to think in a linguistic system of reference. ${ }^{28}$ He experiences and interprets the physical world through the

27 Su Shi, “Qianzhou Chongqing Chanyuan xin jingzang ji” 虔州崇慶禪院新經藏記, $s s w J$, 12.390-1.

28 For more on the development of thinking through the child's transformation of his own language in the direction of the mother tongue, see M.M. Lewis, Language Thought and Personality in Infancy and Childhood (London: George G. Harper Co. Ltd, 1963), 47-57. 
medium of the acquired language. Su suggests that when one has achieved the ultimate internalisation of rules, one will "reciprocate the transformation of ten thousand things" without being self-conscious. This is the state of aesthetic spontaneity, and the "divine intelligence and wondrous achievement" of the artist will appear as transcendent as those of the Buddha. But, as Su Shi implies, this is only in the eyes of the "uninitiated". The artist's spontaneity partakes of the absolute spontaneity of the Buddha while still remaining distinct.

This paragraph provides an aesthetic explanation of the principle of 'gaining through no-gaining. The learning of every craft begins with daily progress (gaining). Once all the rules are completely internalised, he realises that there is nothing else to gain since everything is now inside of himself. He will then reach the moment of true gaining - gaining nothing and everything. The rules thus fade from the surface of consciousness into subconsciousness. On the road towards aesthetic spontaneity, oblivion completes mnemonics.

Su's comparison of calligraphy to the learning of a language is further explored in his encomium on the calligraphy of the Heart Sütra. It suggests that calligraphic styles practised since childhood can be naturalised, just like a native tongue. If practised only since adulthood however, it paradoxically requires constant mental control to enter the state of oblivion.

草隸用世今千載 The cursive and the clerical scripts have been used for a millennium;

少而習之手所安

如舌於言無揀擇 終日應對惟所問 忽然使作大小管

如正行走值墻壁 縱復學之能粗通 操筆欲下仰尋索

譬如散武鳥學人語 所習則能否則默

心存形聲與點畫

何暇復求字外意 世人初不離世間 we practise them from childhood, and our hands feel at ease.

Like the tongue's not deliberating to choose words, but simply answering and responding all day long. Suddenly if we are made to write in big or small seal scripts,

it would be like walking into a wall.

Even if we learn and grasp the basics, when we hold the brush, about to write, we still need to ponder.

Like a parrot which has learned to speak:

it says what it has learned, and otherwise becomes mute.

If we keep fast in mind forms and sounds, or dots and strokes,

how could we seek the spirit beyond script?

People in the world cannot leave the world; 
而欲學出世間法 but they want to learn the dharma transcendent to the world.

舉足動念皆塵垢 Every single movement and thought are stained in dust;

而以俄頃作禪律 though at whiles they strive for meditation and discipline.

禪律若可以作得 所不作處安得禪 善哉李子小篆字 其間無笔亦無隸 心忘其手手忘筆

\section{筆自落紙非我使} If one can strive for meditation and discipline, when one does not strive, where is one's meditation? How fine! Mr. Li's calligraphy in small seal script style; it seems neither in seal nor in clerical script.

When his mind forgets his hand, and his hand forgets his brush,

his brush falls to the sheet by itself, not driven by his self.

正使忽忽不少暇 Within a fleeting moment, without any rest, 修忽千百初無難

稽首般若多心經 請觀何處非般若 he has written swiftly hundreds of characters with no stress.

Let me worship the Heart Sütra of Wisdom, and observe where this wisdom is not present! ${ }^{29}$

Su Shi argues that Mr. Li's calligraphy in small seal script is so fine because he disregards the distinction between this later-mastered style and the naturalised clerical script. Otherwise he would be like a parrot learning to speak: mindlessly and slavishly repeating the sounds without comprehension, and only being able to utter just these sounds. Since he related the 'foreign language' (seal script) to his 'mother tongue' (clerical script), he could then 'forget' the mediating means (hand and brush) and write as if pouring his mind directly onto paper. Su Shi further compares the learning of the seal script to the practice of Buddhist meditation. To acquire the dharma, he argues, one must habitually exercise mental control until one forgets one's will for control. One's mind then becomes constantly meditative.

Modern research on infanthood suggests that babies have the extraordinary ability to utter all kinds of sounds. During the process of acquiring a native tongue, however, a baby will lose much of its linguistic malleability and be restricted to much of the sound spectrum of one or more particular languages. ${ }^{30}$ In a certain sense, a child becomes a full human being when he has learned to behave in accordance with cultural norms. Acquiring virtuosity in art,

29 Su Shi, “Xiaozhuan Bore Xinjing zan” 小管般若心經贊, sswJ, 21.618.

30 M.M. Lewis, Language Thought and Personality, 20-2. 
similarly, is to restrict the movements of a certain physical faculty according to the established technical rules of an art. The relevant part of the artist's body forms such professional habits that its movements are modularised, even in the seeming absence of mind. Artistic spontaneity is associated with restriction and manipulation.

On the other hand, the rules help to set up a boundary that is a reference for the expression of freedom. As Su Shi's praise of Wu Daozi's painting states, $\mathrm{Wu}$ had exhausted all the possibilities of this art so he could "express novelty within the measures of rules, and lodge subtlety beyond heroic abandon” 出新意 於法度之中, 寄妙理於豪放之外. ${ }^{31}$ Later, critics used precisely the same terms to describe Su Shi's contribution to poetry. ${ }^{32}$ This allowed Su Shi, as Ronald Egan has noted, to position himself between two extremes - that is, between the abolition of the tradition and its slavish study, so that he could find a way "of reconciling the weight of the tradition with his quest for novelty". ${ }^{33}$

What should be completely absorbed and then 'forgotten' are not only artistic skills but also subject matter. In more than one instance, Su Shi argues that one should thoroughly study the representational object - not to mechanically memorise it, but to absorb, transform and create a mental image of it. In a colophon on the "Mountain Villa" painting (Shanzhuangtu 山莊圖) by Li Gonglin 李公麟 (1049-1106), an exemplary literatus painter, Su Shi praises it as a marvellous representation of the true mountain. When he is asked whether it is because Li has a wonderful memory (Li did not paint in situ), Su disagrees. Instead, as he explains, when Li was in the mountain, his mind did not "linger upon things, so his spirit communicated with the myriad things". ${ }^{34}$ Memorisation suggests attachment, impairing the spontaneous mobility of the mind. But how exactly can the painter represent his subject matter without memorising the forms of things? In the aforementioned record of Wen Tong's painting of bamboo, Su recounts Wen's instruction that the painter shall first "have a complete bamboo in the breast", then "holding a brush in hand, observing it long and thoroughly, he will see what he wants to paint". ${ }^{35}$ It appears that the bamboo he has in the breast is a generic bamboo; the duration of his long observation on the bamboo in his mind marks a gradual process of imagination,

31 Su Shi, “Shu Wu Daozi hua hou” 書吳道子畫後, sswJ, 70.2210-1.

32 For example, an often-quoted comment by Zhao Bingwen 趙秉文 (1159-1232); see “Dongpo Sidazhai ming” 東坡四達齋銘, in Zhao Bingwen, Fushui ji 滏水集, sKQS, 1190.20.1.

33 Egan, Word, Image, and Deed, 275. Egan has also noted Su Shi's proposal of becoming oblivious to the rules at the moment of execution; see ibid., 276-81.

34 Su Shi, “Shu Li Boshi Shanzhuangtu hou” 書李伯時山莊圖後, sswJ, 70.2211.

35 Su Shi, "Wen Yuke hua Yundang Gu yanzhu ji”, sswJ, 11.365. 
through which he can finally visualise an individual bamboo that he wants to paint. Having the generic bamboo form in mind allows the painter to 'forget' the actual bamboo that exists outside his imagination. The eventual evolution of the generic to the individual is simultaneous with the process where memory fuses into both imagination and creation.

The idea of visualising a mental image as the blueprint of artistic representation is an old one. Michael A. Fuller argues that the Chinese notion of emotion (qing 情) essentially allows the fusion of the inner and the outer, since qing also means 'circumstances' ${ }^{36} \mathrm{Lu}$ Ji's 陸機 (261-303) "Rhapsody on Literature” (Wenfu 文賦) was an early elaboration on the inspirational process:

In the beginning he withdraws sight,

Suspends hearing, deeply contemplates, seeks broadly.

Letting his spirit race to the eight limits,

Letting his mind roam ten thousand spans.

Then, at the end, his feelings, first glimmering, become even brighter;

Things, clear and resplendent, reveal one another.

其始也, 皆收視反聽, 耽思傍訊, 精柔鹪八極, 心游萬仞。其致

也，情曈曨而彌鮮，物昭晰而互進。37

In this theory, inspiration begins in a meditative state. The writer induces his mind to sink into subconsciousness, from where his imagination is able to explore the entire cosmos. Lu Ji's phraseology suggests that the mind does not actively seek or select images of things; rather, those mental images emerge spontaneously from the abyss of consciousness - in his own words, like fish biting the bait. The same process is summarised by Liu Xie as:

Be tranquil and contemplative,

So the thought communicates with a thousand years.

In silence the expression moves,

When the sight has penetrated ten thousand $l i$.

寂然凝慮，思接千載。悄焉動容，視通萬里。38

$36 \quad$ Fuller, "Pursuing the Complete Bamboo", 12.

37 See Lu Ji, Lu Ji ji 陸機集 (Beijing: Zhonghua shuju, 1982), 1-2. I have here followed David R. Knechtges' translation. See David R. Knechtges, Wenxuan, or Selections of Refined Literature, vol. III (Princeton: Princeton University Press, 1996), 215.

38 In ch. 26, "Shensi” 神思; see Yang Mingzhao, Zengding Wenxin diaolong jiaozhu, 6.369. 
Liu Xie describes this contemplative state as "emptiness and tranquillity" ( $x u$ jing 虛靜), where the "divine inspiration" can be shaped like pottery (taojun shensi 陶鈞神思). Note again the metaphor of pottery making, which compares artistic composition to cosmic creation. The emphasis on the meditative mental state as the preparatory stage for writing assumes that there is a homogenous relationship between the writer's mind and his style. Therefore, his mental state is reflected in the aesthetic appearance of his work. As Su Shi argues, such direct correlation is ensured when the skills are fully internalised.

As cited earlier, Su Shi compared his own writing to a gushing river. The river is a universal symbol of the art of subconsciousness and oblivion. The classical scholar Harald Weinrich argues that the river of magic water is a significant symbolism for art. In Greek mythology, Lethe is the stream of oblivion running through Hades. In its "soft flow", "the hard contour of reality-remembrance is lost and becomes "liquidized". ${ }^{39}$ Weinrich argues that, etymologically, the Greek word for truth, aletheia, is comprised of a negative prefix $a$-, followed by -leth-. Thus, European philosophy which follows the Greek tradition has for many years sought truth from the side of non-oblivion, as well as memory and remembrance. ${ }^{40}$ In contrast, oblivion liberates man from the burden of memory, sorrow and pain. In the cult of Dionysus, wine is bestowed by gods as a divine drug to "dispel sorrows" (Euripides). ${ }^{41}$

In early Chinese culture, the intrinsic relation of knowledge to memory is expressed through the word shi 識 ('to recognise, to know'), which in Shiming 釋名 (Expounding the Names) is glossed as zhi 幟, namely, 'to mark'; to leave a mark for future inspection. ${ }^{42}$ The association of wine and oblivion in China is particularly pronounced in the literature of the Six Dynasties, as well as in that of the Tang. In particular, calligraphers who practised the cursive script style liked to drink. Shi Cangshu, for instance, named his studio 'Drunken Ink'. He possibly used alcohol to loosen conscious control, sink into a state of oblivion, and execute his calligraphy in the dimming light of consciousness. Obviously, drinking was employed as a 'skilful means' to approximate the ideal state of spontaneity. In a rhapsody extolling the power of wine, ${ }^{43} \mathrm{Su}$ Shi described the state of drunkenness as "sitting in oblivion" (zuowang 坐忘). This

39 Harald Weinrich, Lethe: Kunst und Kritik des Vergessens (2nd edition) (Munich: C.H. Beck, 2005), 18.

$40 \quad$ Ibid., 15 .

41 Ibid., 25-30.

42 Liu Xi 劉熙, Shiming, 12.39; see Wang Xianqian, Shiming shuzheng bu 釋名疏證補 (Shanghai: Shanghai guji chubanshe, 1984), 176.

43 See Su Shi, “Zhuoliao you miaoli fu” 濁醪有妙理賦, sswJ, 1.21-2. 
term, from the Zhuangzi, refers to the greatest achievement in spiritual practice when a person loses his sense of self and feels that he is living in non-duality with the external world. ${ }^{44}$

In the Western tradition, the art of oblivion (ars oblivionis) is the bliss of darkness which heals humans from the scorching light of truth. Truth, in turn, is a certain kind of mnemonics, as for Plato, it is the remembrance of the shining eidos in Heaven that the soul was once exposed to. Oblivion is consequently a liberating force. Drinking the water of Lethe will free a person from his earlier existence, leading to his rebirth in a new body. Similarly, in our case, oblivion temporarily liberates the artist from his unrelenting pursuit of enlightenment. Mythical and theological though it may sound, an artist living in the human realm must first transform his physical being to embody the Way before attaining full spontaneity. And if he could do this, would he still be a man? Su Shi has stated that human nature is, by necessity, imperfect. Everyone should keep trying; no one can reach the goal. The practice polishes one's art but also becomes a burden. Oblivion at the moment of composition liberates one's creativity and allows one to reach a conditioned spontaneity - spontaneity expressed through material media.

\section{Lodging in a World of Resemblance}

The notion of conditioned liberation was commensurate with Su Shi's ideal of the 'Middle Way' (zhongdao 中道). In the terminology of the 'Threefold Truth' theory of Tiantai Buddhism, ${ }^{45}$ the practice of art becomes an act of lodging in a world between the conventional existence and the ultimate truth of emptiness. As will be seen in the following account by Su Shi on his painting studio Snow Hall (Xuetang 雪堂, built in the winter of 1082 during his exile in Huangzhou [1080-1084]), this is a world of resemblance, where the forms of things are represented through art. For Su Shi, this world provided the ultimate sanctuary for the displaced. Su Shi's Huangzhou exile would have been a misfortune, were it not that he considered himself lucky enough to survive the prosecution at the Crow Terrace at all. ${ }^{46}$ The prosecution ended Su's earlier political ambition. In Huangzhou, Su tried to interpret his suffering as an or-

\footnotetext{
44 See ZZJS, 6.284.

45 See ch. $1,46$.

46 Su was prosecuted because of his opposition to the New Policies reform. On this prosecution, see Charles Hartman, "Poetry and Politics in 1079: The Crow Terrace Poetry Case of Su Shih", Chinese Literature: Essays, Articles, Reviews (CLEAR) (1990), 12: 15-44. See also
} 
deal that tested his integrity and purity. Being an outcast, he rediscovered a selfhood detached from political glory or disgrace. The exile was consequently a liminal period in Su's life, through which he redefined his own identity. Perhaps inspired by Yoshikawa Kōjirō's argument on the Song poetry's transcendence of sorrow, ${ }^{47}$ Michael A. Fuller points out that, Su Shi's

poetic personality, with its firm, philosophic, yet jovial poise of spirit, was created by Su Shi's major writings in Huangzhou. [...] [T] he image of Su Shi finding joy even in the worst of adversity has become part of the Chinese cultural heritage. 48

As this book argues, first of all, achieving such a state of transcendence was gradual in Su's life; second, it is a textual construction. Not only is it an image of Su's poetic persona built by text, but Su himself might have thought through these texts to arrive at temporal and provisional serenity.

Writing was crucial in transforming adversity into opportunity. Su Shi's style name, Dongpo, or 'East Slope', refers to a piece of wasteland, east of the city wall, which he farmed for his livelihood. This term, however, also alludes to Bo Juyi, who, during his tenure at Zhongzhou (in modern Sichuan province), gardened on a slope east of the city. ${ }^{49}$ The naming of the 'East Slope' and the assuming of it as his style name suggest that $\mathrm{Su}$ tried to enrol Bo as his literary precursor. By doing so, he found strength in emulating Bo's philosophical optimism. Aside from farming and writing, Su found further spiritual relief in painting and calligraphy. Snow Hall was built in the slack season of winter. Farming saved him from starvation, while artistic creation in the studio, as can be seen from the following account, would liberate him from fear, self-pity and shame.

\section{A Record of Snow Hall 雪堂記50}

[1] Master Su acquired a deserted garden by the East Slope. He constructed a fence around it and built a hall in it, calling the middle studio

Peng Jiuwan 朋九萬, Dongpo Wutai shi'an 東坡烏臺詩案 (Taipei: Yiwen yinshuguan, 1968).

47 Yoshikawa, Introduction to Sung Poetry, 24-8.

48 Michael A. Fuller, The Road to East Slope (Stanford: Stanford University Press, 1990), 251.

49 See Bo Juyi, “Dongpo zhonghua ershou” 東坡種花二首, in Bo Juyi ji, 11.215-6.

$5^{0} \quad s s w J, 12.410-3$. This essay also appeared with some textual variants and a different title: “Xuetang wen Pan Binlao” 雪堂問潘分老, in Su Shi, Dongpo zhilin, 4.80-3. 
'Snow Hall'. Since this hall was built in a heavy fall of snow, he painted snow on the four walls without a single space left blank. Wherever he was in activity or in repose, looking around, it was all snow. When Master Su dwelt in it, he was truly at home! Master Su leaned on a desk and fell asleep in the day. Vividly, he felt he was going somewhere and was about to arise. Before he woke up, something touched him and he was stirred. So he did not manage to go where he intended to go. He felt as if in a loss. He rubbed his eyes with his palms and put his feet into his shoes, dragging himself to wander outside the hall.

\section{蘇子得廢圃於東坡之脅, 築而垣之, 作堂焉, 號其正曰雪堂。 堂以大雪中為之, 因繪雪於四壁之間, 無容隙也。起居偃仰, 環顧睥睨, 無非雪者。蘇子居之, 真得其所居者也。蘇子隱几 而書瞑, 栩栩然若有所適而方興也。未覺, 為物觸而寤, 其適 未猒也，若有失焉。以掌抵目，以足就履，曳於堂下。}

The record begins with a realistic narrative: the location of the hall, its construction, the reason of its naming, and so forth. Yet everything about the hall suggests a certain marginality and liminality. The garden had been a wasteland, located outside the city wall; the hall was built in heavy snowfall, when the world was monochromatic and blanketed in obscurity; and the owner is an exile. To befit the setting, the walls are covered with paintings of snow. A painting of snow painted with black ink creates the supreme visual illusion. It is paradoxical, just like articulating the wordless or naming the nameless. The function of this hall is to provide a tangible material abode for the poet's mind. Snow Hall is thus a liminal realm of naming and illusion-making. Analogous to the art world, it is a self-sufficient and shadowy realm of resemblance, located between the conventional existence and the Great Void. The poet finds it truly delightful.

The author refers intensively to the Zhuangzi in describing his life in Snow Hall. "Leaning on a desk" 51 alludes to the self-less state of 'sitting in oblivion'. The term xuxuran 栩栩然 that he uses to describe his daydream alludes to the famous story in which Zhuangzi once dreamed that he was a butterfly. As Zhuangzi said, his dream felt as vivid (xuxuran) as in reality. When he woke up, he found himself to be Zhuangzi again. So he did not know whether he was Zhuangzi who had dreamt that he was a butterfly, or a butterfly now dreaming that he was Zhuangzi. ${ }^{52}$ The daydreaming Su Shi thus appears to be residing in

$5^{1} \quad$ See the "Qiwulun" chapter, zzJS, 2.43.

$5^{2} \quad$ ZZJS, 2.112. 
non-duality, finding no distinction between his self and the external world of things. He is woken up, however, in his daydream (as implied by the phrasing: 'he was stirred but did not wake up') by a certain 'thing. The following account appears to be a dream within the daydream. His self is again juxtaposed with the 'thing'. Thus, feeling at loss, he does not manage to reach the true realm of non-duality.

[2] There came a guest. He asked, "Are you a man disengaged from the world or fettered by the world? To be a disengaged man, you are too shallow in Heaven's endowment. ${ }^{53}$ To be a fettered man, you need to sink deep in lust and desire. Now you are like a horse bridled to stop. What have you gained, or what have you lost?" Master Su felt as if he realised something in mind, but he could not put it into words. He pondered on how to respond, while bowing to invite the guest into the hall.

\section{客有至而問者曰：“子世之散人耶，拘人耶? 散人也而天機 淺, 拘人也而啫慾深。今似繋馬而止也, 有得乎而有失乎? ” 囌子心若省而口未嘗言, 徐思其應, 揖而進之堂上。}

The guest appears to him from the 'outside'. There is no description of the appearance of the guest - neither his looks nor his attire. In other words, he does not belong to the world of form and materiality, but to the 'outside' world of truth, of non-being. The term sanren 散人 refers to another story in the Zhuangzi. When Craftsman Shi went to Qi, he saw a gigantic sawtooth oak on an altar. He passed by without giving it a second glance. His apprentices were puzzled and asked why. Craftsman Shi replied that it had acquired longevity exactly because it was a 'useless tree' (sanmu 散木). That night he dreamt of this oak tree, which politely protested that, were it useful, it would have already been humiliated or destroyed. Furthermore, being a mortal heading towards death, Craftsman Shi himself would also end up being a 'useless man' (sanren). ${ }^{54}$ San literally means 'to disperse', 'to let loose' or 'to disengage'. Thus a sanren is

53 A term from the "Dazongshi" chapter in the Zhuangzi. This passage describes the "true man' (zhenren 真人) of old, who did not dream while asleep and did not worry while awake. In contrast, those who were deep in lust and desire were shallow in Heaven's endowment. See zzJs, 6.229. A variant for tianjiqian 天機淺 is weineng 未能 (see Su Shi, "Xuetang wen Pan Binlao", Dongpo zhilin, 4.80), which will clarify the meaning of this sentence as, "To be a disengaged man - you are unable to".

See zzJS, 4.170-4. In the context of the Zhuangzi, 'useless' will be a more accurate translation for san, as will be elaborated upon in the next chapter. Here I chose to translate san as 'disengaged', in order to maintain consistency throughout the text. 
a person useless to the world and disengaged from it. The guest understands Su's dilemma: he is somewhat between two worlds, between gain (the knowledge of non-duality) and loss, or freedom and imprisonment. Su Shi is unable to respond, but he invites the guest into his liminal world of resemblance, where, as we are going to see, art both liberates him from the phenomenal world and imprisons him in it.

[3] The guest then said, "Yes, I see! You desire to be a disengaged man without success! Now let me tell you the way to become disengaged. As for how Yu channelled the flood to the ocean ${ }^{55}$ or Cook Ding applied his knife to a bull ${ }^{56}$ - they avoided all hindrances and were truly wise in disengaging. Therefore, when the softest [water] rides the hardest [rock], rocks will split in due time. ${ }^{57}$ Using the hardest [knife] to cut the softest [flesh], this is why Cook Ding does not see the whole bull. If you can disengage, nothing can fetter you. If you cannot, nothing can release you. If you are intelligent, apply it inside! Now you are like a hedgehog in a sack that sometimes arches its back. What can be seen outside are just one or two hairs. ${ }^{58}$ The wind cannot be kneaded; the shadow cannot be caught - even a child knows that! A name to a man is just like the wind or the shadow. But you alone lingered [upon the name]! Thus upon seeing your name the foolish are startled, and the wise arise and chide you. I am indeed surprised you have come to the present stage so late! It is fortunate of you to meet me. Now I invite you to roam beyond the boundaries, would you?"

客曰：“嘻, 是矣, 子之欲為散人而未得者也。予今告子以散 人之道。夫禹之行水, 庖丁之投刀, 避眾礙而散其智者也。是 故以至柔馳至岡, 故石有時以泑。以至剛遇至柔, 故未嘗見全 牛也。予能散也, 物固不能縛, 不能散也, 物固不能釋。子有 惠矣, 用之於內可也。今也如蝟之在囊, 而時動其脊脅, 見於 外者, 不特一毛二毛而已。風不可摶, 影不可捕, 童子知之。 名之於人, 猶風之與影也, 子獨留之。故愚者視而驚, 智者起

55 See ch. 1, fn. 48 .

56 "Introduction", fn. 29.

57 The “Kaogongji” 考工記 chapter in the Rites of the Zhou states, "Rock splits, water freezes, ice melts - all in due time, this is called the Heaven's timing”. See Sun Yirang, Zhouli zhengyi, 74.3121.

58 An idiomatic expression to describe numerousness, first used by Jia Yi 賈誼 (200-168 BCE); see Yan Zhenyi 閻振益, Xinshu jiaozhu 新書校注 (Beijing: Zhonghua shuju, 2000), 1.57 . 
而軋, 吾固怪子為今日之晚也。子之遇我, 幸矣, 吾今邀子為 藩外之遊, 可乎?”

Once inside Su's world, seeing the snow painting, the guest begins to understand his plight. He then tries to enlighten $\mathrm{Su}$, teaching Su the way of disengagement. For him, intellect should be hidden inside, not shown to others. According to Zhuangzi, when a man makes himself useful to the world, he would be charged with all kinds of responsibilities and deprived of his selfsufficiency. ${ }^{59}$ Now, Su Shi in Snow Hall has hidden himself largely from the sight of others. But, just like the hedgehog in the sack which could not help arching its back, he cannot help writing or painting. Creating art is one way of showing his intellect. The guest questions why Su Shi lingers upon the name, ming 名, a multivalent word referring both to name and to fame (when it is used as a verb, meaning 'to make a name known'). Su Shi betrays his attachment to the name in the naming of the hall, as well as in his making of artwork, which would potentially increase his fame. To help Su Shi sever his attachment, the guest invites him to roam beyond the boundaries.

[4] Master Su said, "At this stage, I think that I have been long beyond the boundaries! Where else do you want to go?" The guest said, "Fie! How extremely difficult it is to make you understand! Power and wealth are not enough to be the boundary. Fame and vainglory are not enough to be the boundary. The forces of yin and yang are not enough to be the boundary. Human norms are not enough to be the boundary. Our boundary is intelligence alone! Intelligence lodges within. When it is manifested in words, the words have meaning; when it is manifested in actions, the actions have meaning. Now it makes you desire to be silent but cannot be silent and desire to rest but cannot rest. It is like the angry words of a drunkard or the wild behaviour of an insane person - though his mouth is covered and his arms caught, he is still mumbling and wriggling. So your boundary is especially steadfast on you! Man has worries because of his having a body, and his body has worries because of his having a mind. Now you build a hall in the garden. Is it to comfort your body? Now you paint snow in the hall. Is it to comfort your mind? If your body depends upon the hall to be at ease, you cannot be released from your form. If your

59 There are a few stories in the Zhuangzi expatiating upon this morale; see zzJs, 1.39-40, 4.170-4, 20.667-8. See also Rune Svarverud, "The Usefulness of Uselessness", in Studies in Chinese Language and Culture, eds. Christoph Anderl and Halvor Eifring (Oslo: Hermes Academic Publishing, 2006), 157-68. 
mind depends upon the snow to be alert, you cannot solidify your spirit. Your intelligence has been burnt to ashes, ${ }^{60}$ but now the ashes are catching flames again. So the building of this hall cannot benefit you but will only further obscure your mind. When you see the snow's being white, your eyes are dazed by its radiance. When you see the snow's being cold, you feel a sudden chill and hairs erect on your skin. The harm of the five senses is the gravest through the eyes. That is why the Sage never does it. Oh, snow, snow! I see that your intelligence is dependent on your eyes. You are in danger!"

\section{蘇子曰：“予之於此, 自以為藩外久矣, 子又將安之乎?”客 曰：“甚矣，子之難曉也。夫勢利不足以為藩也，名譽不足以 為藩也, 陰陽不足以為藩也, 人道不足以為藩也。所以藩予 者, 特智也爾。智存諸內, 發而為言, 而言有謂也, 形而為 行, 則行有謂也。使子欲嘿不欲嘿, 欲息不欲息, 如醉者之恚 言, 如狂者之妄行, 雖掩其口執其臂, 猶且喑嗚踞虞之不已, 則藩之於人, 抑又固矣。人之為患以有身, 身之為患以有心。 是圃之構堂, 將以佚子之身也? 是堂之繪雪, 將以佚子之心 也? 身待堂而安, 則形固不能釋。心以雪而警, 則神固不能 凝。子之知既焚而燼矣, 燼又復然, 則是堂之作也, 非徒無 益, 而又重子蔽蒙也。子見雪之白乎? 則恍然而目眩, 子見雪 之寒乎? 則竦然而毛起。五官之為害, 惟目為甚。故聖人不 為。雪乎, 雪乎, 吾見子知為目也。子其殆矣！”}

In this playful dialogue, the guest chides Su Shi for his ignorance because intelligence is also a prison, the hardest one to break. This idea has its root in Daoism, ${ }^{61}$ but the term Su uses (zhifu 智縛) appears to have been inspired by the Buddhist term 'the hindrance of intelligence' (zhizhang 智障), ${ }^{62}$ which is regarded as the reason why the most gifted cannot be enlightened. Su Shi, when writing his essay, appears to believe that he belongs to this category though writing brought him close to disaster, it has become his second nature, too deeply internalised to eradicate. ${ }^{63}$ The guest warns him that using art as a

6o Referring again to the state of 'sitting in oblivion'.

61 In the "Quqie" 胠策 chapter in the Zhuangzi, it states, "Discard sagaciousness and abandon intellect - so the great bandits will disappear"; see zZJs, 10.353. Similar statements are also found in the "Zaiyou" 在宥 chapter in the Zhuangzi (ibid., 11.377); as well as in Laozi (see Zhu Qianzhi, Laozi jiaoshi, 19.74).

62 See Mohezhiguan 摩訶止觀, T no. 46, 1911.16c.

63 It was, in fact, a general belief about Su Shi in and after his time. Ever since the Song, some 
'skilful means' is a double-edged sword: taking delight in it seemingly helps the student to sever his worldly concerns, but it also fosters a dangerous kind of dependence, preventing him from acquiring the real Way. Furthermore, the form of the snow stimulates his sensory faculties and disturbs the stillness of his mind. What Su Shi has taken in the beginning as the ease, is now reversed by the guest as the greatest 'danger' (dai 殆).

[5] The guest then raised his stick to point at the walls, saying, "Here it is concaved; here it is raised. When the snow falls indiscriminately, its surface is even. When a strong wind blows, the concaved snow stays and the raised disengages [or 'disperses']. Does Heaven show favouritism to the concaved snow and dislike the raised? It is decided by the situation. What is decided by the situation cannot even be violated by Heaven, not to say by man! Though you live here far apart from men, you still build this hall in the garden and give this name to the hall. Is it not a hindrance just like the snow on the concave surface [and unable to disengage]?" Master Su replied, "I did it because this idea happened to come to me. Did I intend to do so? Now I am in danger, but what can I do about it?" The guest said, "You say it happened to come to you - if it happened to rain, would you have painted the rain? If it happened to be windy, would you have painted the wind? The rain could not be painted, because if you see the dark cloud roaring and surging, you will be moved into rage. The wind cannot be painted, because if you see the grass and trees being overwhelmed by the wind, you will feel fearful. Looking at this snow must also be moving you from inside. If your mind moves, it does not make any difference if the painting is embellished or not, with ice and snow ${ }^{64}$ or with water and rock. When virtue has mind and mind has eyes, ${ }^{65}$ are they not all infringed by external things?"

Buddhist masters used Su Shi as a textbook example to illustrate the doctrine of 'the hindrance of intelligence'; see Grant, Mount Lu Revisited, 181.

64 The original term in the text is "water and snow" (shuixue 水雪), but I find this line obscure. There is one variant for shuixue as bingxue 冰雪 (see sswJ, 12.414, n. 28; Su Shi, Dongpo zhilin, 4.96, n. 13), which I use in my translation. It does not reduce the obscurity but it helps to avoid the repetition.

65 In the "Lie Yukou" 列禦寇 chapter in the Zhuangzi, it states that the greatest harm is for virtue to have mind (i.e. intention) and mind to have eyes. According to the commentaries, the passage warns against one deliberately feigning virtue or seeing with imagination. See zzJS, 32.1057-8. 


\begin{abstract}
客又舉杖而指諸壁, 日：“此凹也, 此凸也。方雪之雜下也, 均矣。庽風過焉, 則凹者留而凸者散, 天豈私於凹而厭於凸 哉, 勢使然也。勢之所在, 天且不能違, 而況於人乎? 子之居 此, 雖遠人也, 而圃有是堂, 堂有是名, 實礙人耳, 不猶雪之 在凹者乎?” 蘇子曰：“予之所為, 適然而已, 豈有心哉, 殆 也, 奈何!”客曰：“子之適然也, 適有雨, 則將繪以雨乎? 適有風, 則將繪以風乎? 雨不可繪也, 觀雲氣之洶湧, 則使子 有怒心。風不可繪也, 見草木之披靡, 則使子有懼意。覩是雪 也, 子之內亦不能無動矣。苛有動焉, 丹青之有靡麗, 水雪之 有水石, 一也。德有心, 心有眼, 物之所襲, 峘有異哉? ”
\end{abstract}

Using the snow as an analogy, the guest explains that Su could not 'disengage' not because he is disliked by Heaven, but because he is still tied to form and name. This discourse is indeed not so much about painting, but instead about naming. It is the name 'Snow Hall' itself which makes a difference between the hall and other spaces. Painting illusory snow on the walls complements the act of its naming. Although Snow Hall transcends fettering forces like power, fame and human norms, naming it as such already exposes Su's attachment to names. Unable to refute the charge, Su pleads that he did not intend to paint the snow, but it simply occurred to him to do so. The relentless guest, however, challenges his claim. He points out that making art cannot be void of intentionality, since he must make a choice among available forms. The fact that he did not paint the rain or the wind shows his preference for the snow.

What Su Shi has chosen not to paint is telling. The surging dark clouds may symbolise revolt against the injustice, while the vegetation overwhelmed by the wind may stand for submission to the injustice. He avoids both and paints the snow instead - a symbol of transcendence. Yet the guest keeps making the point that Su's mind is moved regardless of what he paints or how he paints. His intentionality proves that he does not live beyond the boundary of materiality.

[6] Master Su said, "What you said was completely correct. How dare I not listen to your teaching? It is not, however, the whole case yet, and I cannot keep silent. It is like a person in a court hearing who must keep protesting though his case is lost. Do you think there is any difference in climbing a spring terrace ${ }^{66}$ or entering Snow Hall? Compare the snow to

66 In Laozi it states, "The people are pleased as if they are enjoying a bull banquet or climbing a terrace in spring”. See Zhu Qianzhi, Laozi jiaoshi, 20.79. In translating Su Shi's text, I have modified "a terrace in spring" to "a spring terrace" to preserve its literal parallelism to Snow Hall. 
the spring, and the snow is more tranquil. Compare the terrace to the hall, and the hall is more tranquil. When the mind is tranquil, it obtains; when it moves, it loses. The Yellow Emperor was a divine being of old. He once roamed to the north of the Red River and climbed Mt Kunlun. He gazed at the southern terrains and returned. But he lost his Dark Pearl. ${ }^{67}$ The roaming was to release his mind, while the gazing was to lodge his emotions. His mind felt at ease in roaming and his emotions were lodged in gazing, so that when his mind was unblocked and his emotions were released, he forgot his authentic self. Though he got something precious, how could he still hoard his 'jewel'? That was why he lost his pearl. Even so, the mind would not linger long and the emotions would not come back again [to trouble him]. He would by necessity return to his original state. That was why he was alarmed by his loss and had the pearl sought after. Inside this hall, I chase after the things far away and make them near; I collect the things near and contain them inside. I find the things between my eyebrows and my lashes. This is how I have obtained all the pleasure within the whole universe. For those who are intelligent, when they ascend this hall, [upon seeing the snow] they will feel choked without swimming against the stream or feel chilled without the weather being cold. [The painted snow] freezes their skin and purges their pentup worries. They will be rescued from the sarcasm of 'burning hands' 68 as well as from the sickness of 'drinking ice. ${ }^{69}$ Those who tumble on the path of gains and pains in the realm of craze and worry - are they not just like those who are sticking their hands into boiling water or holding burning flames, eager to wash [their hands in snow]? What you have said, sir, was the supreme path, and what I have said is the lower path. However, I can do what you do, but you cannot do what I do. For instance, if you give coarse food to those fed daily with refined cuisine, they will

67 In the "Tiandi" 天地 chapter in the Zhuangzi; the Yellow Emperor lost his "dark pearl" (metaphor for his authentic nature) in the distant roaming to Mt Kunlun. When he returned, he had his ministers seek the lost pearl. Lizhu 離朱 (metaphor for clairvoyance) and Chigou 喫詬 (metaphor for sophistry) both failed, but Xiangwang 象罔 (metaphor for the absence of intentionality) finally found it. See zZJS, 12.414-5.

68 A metaphor for someone being so powerful that whoever touches him gets his hands burnt. It appears to have been used first under the Tang as a satire against Li Linfu 李林 甫 (683-752), a Prime Minister; see Wang Yinglin 王應麟, Kunxue jiwen 困學紀聞 (Shanghai: Shanghai guji chubanshe, 2008), 18.1902.

69 In the "Renjianshi” 人間世 chapter in the Zhuangzi, Ye Gao 葉高 was sent on an extremely delicate diplomatic mission to Qi. He said, "I received the mission in the morning and drank ice in the evening, because I felt so hot inside [from the worry]". See zzJs, $4.15^{2-3}$. 
certainly complain. If you dress those who daily wear embroidered clothes with raw leather, they will certain look ashamed. Your approach to the Way is like refined cuisine or embroidered clothes, which is the supreme path. I will follow you as my teacher, and you can use me as your aid - it is like a man cannot live without clothes or food. I shall follow you! As for our argument today, leave it for later discussion. Let me sing a song to express my mind!"

\begin{abstract}
蘇子曰：“子之所言是也, 敢不聞命。然未盡也, 予不能默。 此正如與人訟者, 其理雖已屈, 猶未能絕辭者也。子以為登春 臺與入雪堂, 有以異乎? 以雪觀春, 則雪為靜。以臺觀堂, 則 堂為靜。靜則得, 動則失。黃帝, 古之神人也。游乎赤水之 北, 登乎崑崙之丘, 南望而還, 遺其玄珠焉。游以適意也, 望 以寓情也。意適於游, 情寓於望, 則意暢情出, 而忘其本矣。 雖有良貴, 豈得而寶哉。是以不免有遺珠之失也。雖然, 意不 久留, 情不再至, 必復其初而已矣, 是又驚其遺而索之也。余 之此堂, 追其遠者近之, 收其近者內之, 求之眉睫之間, 是有 八荒之趣。人而有知也, 升是堂者, 將見其不遡而僾, 不寒而

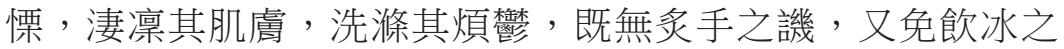
疾。彼其趦䞟利害之途、猖狂憂患之域者, 何異探湯執熱之俟 濯乎? 子之所言者, 上世。余之所言者, 下也。我將能為子之 所為, 而子不能為我之為矣。譬之厭膏梁者, 與之糟糠, 則必 有忿詞。衣文綉者, 被之皮弁, 則必有愧色。子之於道, 膏粱 文繡之謂也, 得其上者耳。我以子為師, 子以我為資, 猶人之 於衣食, 缺一不可。將其與子游, 今日之事, 姑置之以待後 論。予且為子作歌以道之。”
\end{abstract}

After all his excuses are spent and refuted, the poet is inspired to discover the true nature of his action. Stillness and mobility, he argues, are relative to one's point of view. One gains in tranquillity and loses in mobility. In the legend, even the divine Yellow Emperor lost his precious pearl in pleasurable roaming. Mobility, like distant roaming, releases pent-up intentions and emotions. Even though the beneficial effect cannot make up for the loss, only after the therapeutic release may one return to one's original state and try and seek one's 'lost pearl', namely mental tranquillity. For Su Shi, it is easier to achieve transcendence if he lets his mind reside in this hall - itself the resemblance of transcendence. His mediated way, dependent on the 'skilful means' of painting, is perhaps inferior to the guest's absolute independence. But, just as a rich man could no longer take coarse food while a poor man could enjoy delicacies, Su is able to aspire to his guest's Way, while his guest might not understand his. 
Su's argument suggests that the fear over entanglement is not necessary. A person can only follow the way which provides comfort to his nature and ease to his mind. No one can jump from being into non-being. If he tries to do so, he will overstretch his capacity and be further fettered by his greed for liberation. The 'guest', as an 'outsider', cannot understand the necessity of such skilful means. Without immersing himself into the world, he does not know how hard it is for those born in prison to break free. If he understood, he would then pardon minor vices like comfort and ease.

Doctrinal argument, however, falls again into the entanglement of intelligence and rationality. To end it, the poet bursts into song:

[7] Here is my song, "Snow Hall is surrounded, in front and behind, by spring grass of even height. Snow Hall is embraced, to the left and to the right, by narrow paths of no straight lines! In Snow Hall, a gentleman stands high and lofty. ${ }^{70}$ He makes music ${ }^{71}$ in straw sandals and loose hemp robes. He fetches water from a clear fountain, holding a jar in his arms, oblivious to the chicanery of the world. He loads a bamboo basket on his back, singing while walking and gathering the vetches. ${ }^{72}$ I do not know whether I have been wrong for fifty-nine years while today I am correct, or perhaps I have been correct for fifty-nine years while today I

70 The term shuoren 碩人 is the title of a song in the Book of Odes (Mao 57), although originally referred to a female persona. The term also appears in the song "Kaopan" (see fn. 70 below), however as a male persona. $Q i$ 頎 is used in "Shuoren" (literally meaning 'tall'), but it also suggests the nobility and virtue of the persona; see Ma Ruichen 馬瑞辰, Maoshi zhuanjian tongshi 毛詩傳箋通釋 (Beijing: Zhonghua shuju, 1989), 6.202-3. I avoid translating shuoren as 'a tall gentleman' because Su Shi was not known to be tall. Thus, I take some liberty here and translate all the allusions to height as 'standing high and lofty' (that is, his moral stance).

71 The term kaopan 考槃 is the title of a song in the Book of Odes (Mao 56). According to the Mao commentary, kao means to complete, and pan means music; see Ruichen, Maoshi, 6.200-1. Southern Song scholars have proposed different readings. Zhu Xi thought it to mean “to complete one's reclusive chamber"; but Chen Fuliang 陳傅良 (1141-1203) proposed that it means "to clap at a dish-like instrument". For both readings, see Zhu Xi, Shijing jizhuan, in Sishu Wujing, 2.25. These later readings, however, would not have been known to Su Shi.

72 The term caiwei 采薇 is the title of a song in the Book of Odes (Mao 167). However, the context relates it to the legend of Boyi 伯夷 and Shuqi 叔齊, brothers who escaped royal succession, fled into the mountains and lived on wild vetches. See "Boyi liezhuan" 伯夷 列傳, Sima Qian, Shiji, 61.2123. 
am wrong. ${ }^{73}$ I do not know the vastness of Heaven and Earth or the change of seasons. I realise that I have been emaciated in the past while am nourished today. ${ }^{74}$ I am touched by your words! At first they curbed my indulgence and whipped my tongue. Finally they released my fetter and broke my bridle. My building this hall is not to borrow the power of the snow, but only the notion of it. I am not to escape from the world's affairs, but only from its snares. I do not know if one can take delight in the snow; I do not know if one can be subject to the world. The comfort to my nature, the ease to my mind - it is found in no other moment but when the animated multitudes are set into motion and the Great Light rises upon the horizon! Then I toss about on my couch and see the dust flying in the morning rays. If you do not reject me, I will return to you!"

\section{歌曰：“雪堂之前後兮，春草瓶。雪堂之左右兮，斜徑微。雪 堂之上兮, 有碩人之頎頎。考槃於此兮, 芒鞋而葛衣。挹清泉 兮, 抱䳽而忘其機。負頃筐兮, 行歌而採薇。吾不知五十九年 之非而今日之是, 又不知五十九年之是而今日之非。吾不知天 地之大也, 寒暑之變, 悟昔日之瘟, 而今日之肥。感子之言 兮, 始也抑吾之縱而鞭吾之口, 終也釋吾之縛而脱吾之鞖。是 堂之作也, 吾非取雪之勢, 而取雪之意。吾非逃世之事, 而逃 世之機。吾不知雪之為可觀賞, 吾不知世之為可依違。性之 便, 意之適, 不在於他, 在於腒息已動, 大明既升, 吾方輾 轉，一觀曉隙之塵飛。子不充兮，我其子歸。”}

73 Su Shi was only in his late forties when he wrote this essay, thus this line is not actual description, but rather a quotation from the Zhuangzi. In the "Zeyang” 則陽 chapter, when Qu Boyu 鿪伯玉 was sixty sui, he had already transformed himself sixty times; what he thought correct one day might prove to be wrong another day. See zzJS 25.905. The exact same is said about Confucius; see the "Yuyan" 寓言 chapter, ibid., 27.952. Su Shi used this expression again in a letter written in Huizhou (1094-1097); see "Yu Wu xiucai sanshou” 與吳秀才三首, no. 2, ssWJ, 57.1738. His use of this allusion proves to be confusing to some scholars. Wu Xuetao, for instance, decided that the aforementioned letter must be written in 1095, when Su Shi was sixty sui; see Wu Xuetao 吳雪濤, Su wen xinian kaolue 蘇文系年考略 (Hohhot: Neimenggu jiaoyu chubanshe, 1990), 402-3.

Reference to a poem by Han Yu where he laments, "Alas, my Way cannot be used to nourish oneself” 嗟我道不能自肥; see Han Yu, “Song Ou Hongnan gui” 送區弘南歸, QTS, 339.3797. Here, Su Shi borrowed this term with a twist, suggesting that when he felt at ease with himself, he was already physically and mentally nourished. 
Prose recedes to poetry when emotion reaches climax, a transformation that symbolises the succession of analytic to poetic reason..$^{75}$ The form of this song is deliberately archaic, with classical interjection $x i$ 今 and lines of uneven length. It uses a complex rhyming pattern which combines regularity and variations. The major rhyme group is level tone wei, /i-3a/, assisted by five other rhyme groups, including level tone qi rhyme, zhi rhyme, departing tone $z h i$ rhyme, $j i$ rhyme, and entering tone $x i$ rhyme. It means a single line can hold up to three rhymes. Yet the intensive rhyming sometimes breaks, allowing a long sentence like "the comfort to my nature, the ease to my mind [...] and see the dust flying in the morning ray", rhyming only at the end ( fei /fi-3a/ 飛), intimating the fluid flow of climatic emotion. Such a form craftily creates an impression of casualness and spontaneity.

The poet describes himself intensively in phrases borrowed from the Book of Odes. He appears to live in unity with nature and is even oblivious to the distinction between right and wrong. He confesses to have no knowledge about the external world; ergo he becomes sufficient in himself. His song, through a series of negation, leads to a series of affirmation, albeit apologetic ones. It ends with describing the cosmic moment of sunrise, when he wakes up from a dream and welcomes transformation on a grand scale. Observation of the phenomenal world provides comfort to his nature and ease to his mind. Contrary to the guest's negation of any worldly form, this song celebrates artistic creation as his own path to liberation. This song is a piece of art which learnedly defends art as a life-affirming, instead of life-negating, force.

[8] The guest chuckled in pleasure, acquiesced, and took his leave. Master Su followed him out. The guest looked around, nodding slightly, and said, "How could there be such a fellow!"

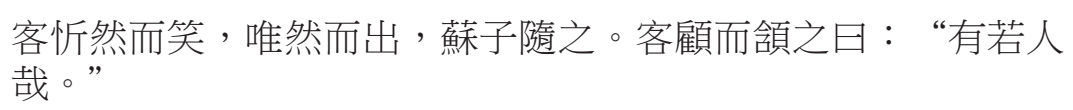

In the end, the guest is persuaded by Su Shi's eloquence. The 'skilful means', which acknowledge human imperfection, may ultimately open an access for the poet to enter the realm of true freedom outside his 'Snow Hall'.

75 Martin Kern has observed similar rhetoric in Han historiography, where heroes (and heroines) usually burst into song at moments of danger and demise; see Kern, "Chutu wenxian yu wenhua jiyi” 出土文獻與文化記憶, Zhongguo zhexue 中國哲學 (2004), 25: 111-58. 
This account simultaneously pays homage to the ultimate Way of negation and defends the aesthetic way of affirmation. Language is necessary for the communication between the two realms. The guest, who is the incarnation of the truth of non-being, has to use language when he bestows his teaching on a man. The man can consequently debate the guest's truth with his own truth. The individual is free to choose between absolute freedom, void of materiality, and limited freedom, within the realm of art.

Conveyed in artful language, Su's contemplation on entering the realm of emptiness seems mere contemplation. He entertains this idea but cannot practise it. As the setting of this account suggests, it was a daydream; and even if he could discard the world, he might not choose to do so. As he wrote in a poem for an accomplished Chan monk:

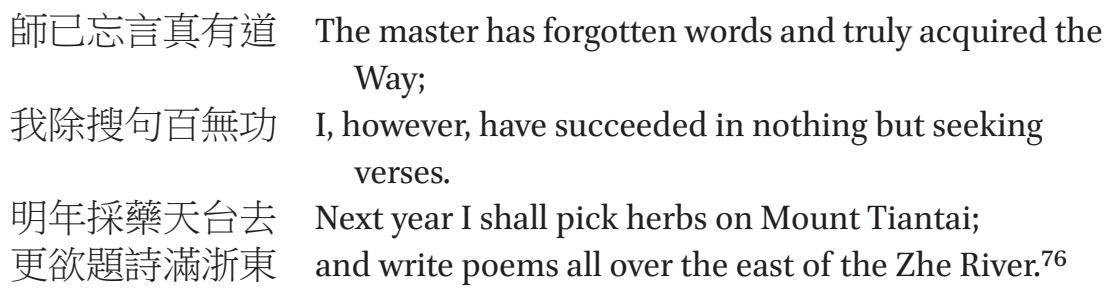

This poem wittily suggests that, if forgetting words was the only path to the Way, Su Shi was not ready for it. A typical Daoist motif, "picking herbs on Mt Tiantai" (literally, 'Heavenly Terrace'), shows his desire for physical transcendence. Writing poems all over the Southeast shows an alternative - not immortality in flesh, but in words.

\section{Coda}

Su Shi usually presented his contemplation on literary immortality in relative terms. It is always the second best: in the Confucian system, to moral or political accomplishments; in the Buddhist system, to enlightenment; and in the Daoist system, to physical immortality. He never went so far as to declare that literary immortality itself was the supreme pursuit, even though invariably this was what he ultimately settled for: a 'Middle Way'. This kind of settlement is possible exactly because artistic spontaneity is born only at the moment when he denies the possibility of ever reaching the 'ultimate goal'. Since Su Shi

76 Su Shi, “Xiuzhou Baoben chanyuan xiangseng Wenchang laofangzhang” 秀州報本禪院 鄉僧文長老方丈, $s s s, 8.412$. 
understands that human nature is imperfectible, the complete spontaneity of an enlightened or divine being remains beyond reach. Thus, a dialectic definition of artistic spontaneity is dynamic. It combines unrelenting pursuit of perfection and temporary resignation to one's imperfection at the moment of execution.

Spontaneity, thus understood, is not a style, but rather a meta-style - in the sense of style being "a mode of personification".77 'Style' shows a family of features which exhibit a common genealogy, constitute the distinctive consistency underlying a corpus of artwork, and is as recognisable (at least to trained eye) as a person's physiognomic features. ${ }^{78}$ Even the physiognomic notion of style, however, does not necessarily assume the homogeneity of the self and the work. A 'spontaneous' work of art, on the other hand, is seen as identifiable with its author. Its aesthetic appearance is transparent, if only deceptively so. It convinces the audience as having conveyed the existential truth of the artist (often understood in traditional China as his moral character) at that particular historical moment, without distortion or mediacy. When the audience looks at such a work, they see instead the living person behind it. With spontaneity becoming the ideal of art, artistic excellence cannot but be defined in individualistic terms. Arguably, the emphasis on spontaneity was correlated with the increasingly bold expression of individualism shaping major Chinese literati arts since the eleventh century.

Susan Bush notes that, in his calligraphy, Su Shi "aimed at spontaneity and directness rather than at aesthetic perfection", and his manner was distinctively individual. ${ }^{79} \mathrm{Su}$ Shi compared the individuality of artistic styles to the individuality of female beauty, both not necessarily perfect. According to him:

\section{短長肥瘦各有態 Being short, tall, plump or slender, each has its own charm; \\ 玉環飛燕誰敢憎 who dares to detest Yuhuan for being fat or Feiyan, being thin? ${ }^{80}$}

Su Shi's calligraphy was often criticised by his contemporaries as technically flawed. They said, for example, that his wrist was not perpendicular, and that

\footnotetext{
77 Berel Lang, "Style as Instrument, Style as Person”, Critical Inquiry (1978), 4.4: 716.

78 Ibid., $726-31$.

79 Bush, Chinese Literati, 6. Su Shi's idiosyncratic style is also noted in Egan, Word, Image, and Deed, 271-2.

$80 \quad$ Su Shi, “Sun Shenlao qiu Momiao Ting shi” 孫莘老求墨妙亭詩, sssJ, 8.371. Yang Yuhuan 楊玉環 (719-756) was the plump Empress of Tang Xuanzong 唐玄宗 $\left(685^{-762 ; r .712-~}\right.$ 756); Zhao Feiyan was the slender consort of Han Chengdi.
} 
his elbow leaned against the paper instead of hanging calmly in the air. ${ }^{81}$ Huang Tingjian, however, defended him with the same analogy of female beauty. “They do not know", Huang scorned, “when Xishi 西施 pressed against her chest and frowned, though it was for her illness, it became her beauty". ${ }^{2}$ Just as truly beautiful women are all beautiful in their different ways, truly outstanding artwork must be individualistic. This means never hiding who one truly is. As quoted earlier, Su Shi learned from many earlier calligraphers, some of whom later lost his respect. But, unlike Mi Fu 米䒾 (1051-1107), who deliberately manipulated his style to erase the traces of such models, Su Shi allowed his calligraphy to betray all these early influences. As Sturman argues, it was because Su Shi simply paid no more attention to his models that he was able to focus on who he was, simply by trusting the brush to leave its own faithful record. ${ }^{83}$ By doing so, his imperfect calligraphy, and his artwork in general, reflects his existential truth.

In the form of individuality, a work of art preserves its author along with his personality and life experience. Artwork is therefore not only the artist's passport to immortality, but also a guarantee of the preservation of his individual, physical traces. After Su Shi's death, Huang Tingjian was once asked to appraise a calligraphic work credited to Su. He examined it carefully and declared it to be a forgery. His reason was:

The calligraphy of Master Dongpo in his late days was especially powerful and heroic, carrying the aura of the winds and waves on the sea. No one can emulate that!

東坡先生晚年書尤豪壯, 挾海上風濤之氣, 尤非他人所到也。84

Huang Tingjian understood that a work of art was not only the overflow of its maker's personality (which is 'powerful and heroic' in Su Shi's case), but also the crystallisation of his life experience in its totality by the moment of its creation. Presumably, Su Shi's last exile to Hainan Island is manifested by the aesthetic appearance of his later calligraphy. The author's spontaneity ultimately

81 Huang Tingjian, “Ba Dongpo Shuilu-zan” 跋東坡水陸贊, in Huang Tingjian quanji, zhengji 28.772 .

82 Ibid. The story of Xishi having chest pain refers to the "Tianyun" 天運 chapter in the Zhuangzi, zzJs, 14.515.

83 Sturman, $\mathrm{Mi} F \mathrm{Fu}, 47$.

84 Huang Tingjian, “Ba weizuo Dongpo shujian” 跋偽作東坡書簡, Huang Tingjian quanji, zhengji 26.673 . 
guarantees his artwork to transubstantiate his self. A kindred spirit will recognise the person from his work and receive it with fondness, carrying this memory within his own being. The 'spontaneous' artwork, in this sense, becomes the transubstantiation of the artist. The identification between the man and his work is thorough and total.

But then it means that the aesthetic ideal of pingdan is applied not only to the artwork, but also to the artist. The man must, through self-cultivation, walk down the path towards discarding external embellishments. This process is characterised as the 'return into nature'. And natural objects, as to be discussed in the next chapter, are often held as exemplars of artwork or the Man of the Way. It is a paradox that such signification only led to the commoditisation of natural objects as works of art. 


\section{Eloquent Stones}

Of the critical discourses that this book has examined, one feature is that works of art are readily compared to natural forms of beauty: bird song, a gushing river or reflections in water are such examples. Underlying such rhetorical devices is an ideal of art as non-art, namely that the work of art should appear so artless that it seems to have been made by nature in its spontaneous process of creation. Nature serves as the archetype (das Vorbild) of art. At the same time, the Song Dynasty also saw refined objects - such as flowers, tea or rocks - increasingly aestheticised, collected, classified, described, ranked and commoditised. Works of connoisseurship on art or natural objects prospered alike. The hundred-some $p u$ 譜 or $l u$ 錄 works listed in the literature catalogue in the History of the Song (“Yiwenzhi" in Songshi 宋史·藝文志) are evenly divided between those on manmade and those on natural objects. ${ }^{1}$ Through such discursive transformation, 'natural beauty' as a cultural construct curiously became the afterimage (das Nachbild) of art. ${ }^{2}$ In other words, when nature appears as the ideal of art, at the same time it discovers itself to be reshaped according to the image of art.

As a case study of Song nature aesthetics, this chapter explores the multiple dimensions of meaning invested in Su Shi's connoisseur discourse on rocks. Su Shi professed to be a rock lover. Throughout his life, he collected inkstones, garden rocks and simple pebbles. We are told, for instance, that a pair of rocks, called Qiuchi 仇池, accompanied him through his exiles to remote Huizhou and Hainan, even though most of his family members were left behind. Su Shi's idiosyncrasy was not just the source of his private delight, but also the subject of public display. He wrote poems, accounts, inscriptions, letters and brush notes to praise the virtue of rocks, record their transactions and justify his possession of them.

1 They are catalogued in juan 205, 206 and 207, mostly under the sub-category of "Agricultural Works" (nongjia lei 農家類). On the bibliographical categorisation of $p u$ and $l u$ works in dynastic histories, see Martina Siebert, Pulu: 'Abhandlungen und Auflistungen' zu materieller Kultur und Naturkunde im traditionellen China (Wiesbaden: Harrassowitz Verlag, 2006), 90-101.

2 This pair of terms, namely, nature as das Vorbild or das Nachbild of art, is borrowed from Martin Seel, Eine Ästhetik der Natur (Frankfurt: Suhrkamp Verlag, 1991), 11. 
The pride that Su Shi took in his passion for rocks was built upon the fact that such an idiosyncrasy was an established elite practice. Since Mid-Tang, as Xiaoshan Yang has argued, a new 'aesthetics of rocks' differentiated this elite taste for rocks from the more simple kind of appreciation in earlier centuries. ${ }^{3}$ Rock connoisseurship fed a frenzy of acquisition. Water-eroded porous rocks were fetched from the bottom of Tai Lake (in modern Jiangsu Province) and transported to the capital to furnish royal or noble gardens. Inkstones, an ancient kind of writing paraphernalia, also gained cult status. The most prized rocks of all were those carved from mountains or water caves, sometimes at the cost of lives. The ethics involved in such practices, however, were not what led Su Shi into soul searching. His particular concern was a type of metaphysical danger. He understood material ownership as a form of slavery to 'things' (wu 物), ${ }^{4}$ a potent threat to his mental freedom. To solve the dilemma, Su Shi argued that one should not force oneself to discard 'things', if they were what one was genuinely fond of, because that deliberate effort would hamper the spontaneous expression of one's innate nature. He further invested the rocks with personality and agency. He transformed their unbelongingness into characteristics of divine beings or recluses. His ownership was therefore redefined as friendship. This set of skilful rhetorical devices is seen at play to achieve various purposes: justifying his material possession, elevating his collection, expediting his acquisition and, sometimes, scuppering a potential transaction. If those rocks, as collectors' items, should be properly considered to be 'superfluous things' (zhàngwu 長物), ${ }^{5}$ their 'uselessness' was, for Su Shi, highly useful.

\section{The Aesthetics of Nature and the Usefulness of Uselessness}

According to Hegel (1770-1831), aesthetics, by definition, is the "philosophy of fine arts". 'Natural beauty' is not a proper field of inquiry because only artistic

3 Xiaoshan Yang, Metamorphosis of the Private Sphere: Gardens and Objects in Tang-Song Poetry (Cambridge, Mass.: Harvard University Asia Center, 2003), 98.

4 Also noted by Xiaoshan Yang, Metamorphosis, 190.

5 A term used in Xu Zhen'e 徐震堮, Shishuo xinyu jiaojian 世說新語校箋 (Beijing: Zhonghua shuju, 1984), 1.27; for the story, see below. For more extensive discussion about this notion in Chinese connoisseurship, see Craig Clunas, Superfluous Things: Material Culture and Social Status in Early Modern China (Oxford, UK: Polity Press, 1991).

6 Hegel, Introductory Lectures on Aesthetics (2004 rpt.), trans. Bernard Bosanquet (Penguin Books, 1993), 3 . 
beauty reflects the freedom of spirit. ${ }^{7}$ Yet, nature does inspire our feelings of beauty, life and freedom - a fact that begs explanation. Kant asserts that nature in itself is neither ugly nor beautiful, and it is only through the perceptive mind of man that it can be experienced as such. Nevertheless, even a bird's song seems to have more freedom and offer more aesthetic pleasure than a human voice singing in accordance with the rules of music. ${ }^{8}$ Arguably, the 'freedom' of bird song is simply a result of its externality to any manmade rules. Thus, the admiration for natural beauty often implies a criticism of human art: insomuch that the former exhibits the principles of spontaneity and unintentionality, the latter is exiled from the realm of absolute freedom, despite its efforts to break rules and boundaries. Yet it is in the nature of 'thought' per se to go beyond sheer materiality. Thus, 'thought' contains the utopian character of transcendence - and ultimately the transcendence from itself. Highly reflective thought therefore tends to see its redemption in its own elimination - and nature turns into utopia. The heart of man's relationship with nature is his criticism of his cultured self.

The contemporary German scholar Wolfgang Kubin argues that the awareness and idealisation of nature in the West appeared parallel to the rise of capitalism and industrialisation, that is, the large-scale assault on the natural environment. As a result, the idealised nature has acquired interiority. It shares the same function as one's innermost self to provide an escape from the pressures of society and civilisation. ${ }^{9}$ With this, ironically, the aestheticised 'nature' loses its independence and becomes a counter image of human culture. It is a constructed, though indispensable, sanctuary to the civilised space.

Nature's purported externality to art defines its meaning. When critics of modern society strive to divorce art from anthropocentric hubris, they find in nature an inhuman language, free of grammar. Walter Benjamin (1892-1940) defines language as the universal capacity for communication, and it is in the nature of all beings to communicate their thoughts. Things 'speak' to man. Only through the linguistic being of things can man gain knowledge of them from within himself, namely, by translating the language of things into that of man..$^{10}$ In Benjamin's hierarchy of language, however, the naming language of man remains the highest and the most perfect kind. In contrast, Martin

\footnotetext{
$7 \quad$ Ibid., 4 .

$8 \quad$ Kant, Critique of Judgement, 73-4.

$9 \quad$ Wolfgang Kubin, Der Durchsichtige Berg: die Entwicklung der Naturanschauung in der chinesischen Literatur (Stuttgart: Franz Steiner Verlag, 1985), 7-8.

10 Walter Benjamin, "On Language as Such and on the Language of Man", in Reflections, trans. Edmund Jephcott (New York: Schocken Books, 2007), 314-32.
} 
Heidegger (1889-1976) distinguishes the 'thing' (das Ding) from the Kantian 'object' (der Gegenstand). According to him, a thing is self-sufficient, while an object is not (the Kantian effort to define a 'thing in itself' [der Gegenstand an sich ] notwithstanding). ${ }^{11}$ Following this string of critical inquiry, the question becomes: if the thing is self-sufficient, why should it communicate with man at all? Paul Celan (1920-1970) suggests that 'things' murmur in their monologues and 'the poet' alone can hear them speaking. He is able to translate the fragments of their words into human language, by which he renews the words worn out in daily communications. ${ }^{12}$ Yet, even so, the 'thing' itself remains beyond touch. As Jean-François Lyotard (1924-1998) observes, it is not waiting to be destined. The 'thing' is presence which cannot be presented to the mind, always withdraws from the mind's comprehension, and does not offer itself to dialogue or dialectic. ${ }^{13}$ The muteness of nature is a mystery. To emulate its silence, Adorno has suggested that 'the poet' must write in parataxis, rebelling against the realistic principle or classical harmony. ${ }^{14}$ Modern art, in its revolt against rules and its emphasis on materiality, appears to be precisely an effort to break into the territory of the absolute spontaneity of things.

Lyotard's argument leads to a question that may never be satisfactorily answered: should nature be understood as presence or as meaning? Hans Ulrich Gumbrecht proposes that materiality is sheer presence, while metaphysics gives higher values to the meaning of phenomena. ${ }^{15}$ In this regard, just like 'artistic spontaneity', tension also underlies the term 'nature aesthetics'. Whenever nature is talked about, it is no longer nature in its sheer material presence, but the linguistic representation of it. The language of things is ultimately defined as what the language of man is not. Yet, such tension is precisely what makes the inquiry particularly pregnant.

See Martin Heidegger, "Das Ding”, in Vorträge und Aufsätze (Tübingen: Günther Meske Pfullingen, 1954), 163-81, esp. 166, 175 .

12 Paul Celan, "Edgar Jené and the Dream about the Dream", in Collected Prose, trans. Rosmarie Waldrop (Manchester: Carcanet Press, 1986), 3-7; and "Conversation in the Mountains", in ibid., 18-20.

13 Jean-François Lyotard, "After Sublime, the State of Aesthetics", in The Inhuman: Reflections on Time, trans. Geoffrey Bennington and Rachel Bowlby (Stanford: Stanford University Press, 1991), 142.

Theodor W. Adorno, "Parataxis: on Hölderin's Late Poetry", in Notes to Literature, trans. Shierry W. Nicholsen, vol. 2 (New York: Columbia University Press, 1992), 108-49, esp. $132-5,148-9$.

Hans Ulrich Gumbrecht, Production of Presence: What Meaning Cannot Convey (Stanford: Stanford University Press, 2004), xiv, 18, 29. 
Our brief summary on this dialectical movement in Western aesthetics may help to illustrate a parallel, though different, discursive system in traditional Chinese aesthetics influenced by Zhuangzi, namely, the discourse against utilitarianism. Many Zhuangzian parables laud the virtue of nature's being useless. One parable tells that when Craftsman Shi went to Qi, he saw a gigantic sawtooth oak over an altar. He passed by without a second glance. His apprentices were puzzled and asked why. Craftsman Shi replied that it acquired longevity exactly because it was not good enough to make anything. That night he dreamt of this oak tree, which politely protested that, were it useful, it would have already been humiliated or destroyed. Furthermore, the craftsman and the tree were both 'things', so why did they not respect each other just as 'things?'16 The moral is that sheer existence is preferable to being useful for others. In another story, Zhuangzi himself becomes a gigantic, useless tree. Huishi, the sophist (who in the Zhuangzi typically represents a 'this-worldly' view), tells Zhuangzi that he had a gigantic Tree-of-Heaven which was good for nothing. Apparently he compares Zhuangzi to this tree: despite his intelligence, Zhuangzi offers no practical suggestions and is a useless man to this world. Zhuangzi replies that this tree shall be planted in the Land-of-Nothingness, so that he will wander by its side and sleep under its shade. ${ }^{17}$ As Rune Svarverud has noted, the moral of these and other stories is the "usefulness of uselessness" (wuyong zhiyong 無用之用). Since useful things are enslaved and harmed in the process of serving others' needs, being useless for others is being useful for oneself. Moreover, uselessness is the ultimate basis of usefulness. Understanding that is a sign of intelligence. ${ }^{18}$

Zhuangzi's poetic imagination of planting the tree in the expansive wilderness, however, implies another way of using the useless - namely, to appropriate it aesthetically. Though extensive descriptions of nature are rare in the Zhuangzi, mythical natural objects and creatures are symbols of inner freedom. This view of nature was uncommon in early China but would become dominant in the Middle Ages. Wolfgang Kubin has characterised the development of the Chinese concept of nature in literature as three continuous stages: from Zhou to Han, nature as sign; in the Six Dynasties, nature as object; Tang, nature as interior. Throughout the development, "nature step by step stands out against society, as the other, and against the I, as the non- $I^{\prime} .{ }^{19}$ Song literature, according to Kubin, shows three views of nature: the non-eulogising view of its ugly side, the humanising approach, and the view of nature as the path of

\footnotetext{
16 See $z Z J S, 4.170-4$.

17 See $z Z J S, 1.39-40$.

18 Svarverud, "The Usefulness of Uselessness".

19 Kubin, Durchsichtige Berg, $33^{2}$.
} 
illumination. ${ }^{20}$ In actual fact, as our discussion on Su's literature on rocks will show, these three views are not distinct but can be correlated in a single system of aesthetics, in which the ugly and the useless become signs of refinement, the humanised objects become symbols of their possessor's moral stature, and the objects themselves become eloquent speakers guiding the path towards illumination.

\section{The Lesson from a Grotesque Rock}

In the Analects, Confucius once complained that he should not be a bitter gourd, hanging on the vine without being eaten..$^{21}$ If a Confucian scholar's duty is to serve - the court, the people, the cultural tradition - a non-serving member of the educated class makes himself 'useless'. By definition, a useless thing is superfluous. In a society ideologically dominated by the economic principle of austerity, the existence of 'superfluous things' raises a moral concern. This term comes from an anecdote on Wang Gong 王恭 (?-398), in Shishuo xinyu 世說新語 (A New Account of Tales of the World). When Wang Gong returned from his tenure in Kuaiji (now Shaoxing, Zhejiang Province), he brought back a beautiful bamboo mat. His clansman Wang Chen 王忱 (?-392) took a fancy to it. Thinking that Gong would have plenty of them, Chen asked for the mat. Gong gave it to him immediately. To Chen's surprise, he later found Gong sitting on a straw mat. When asked why, Gong replied that he never accumulated 'superfluous things.' ${ }^{22}$ Wang Gong's much admired answer suggests that one should not accumulate more material assets than necessary. Judged by this criterion of utilitarianism, the 'useless' - man or object - is dispensable.

On the other hand, the Zhuangzian thoughts have also inspired the Chinese eremitic tradition. The term for recluse, yinshi 隱士, literally means a 'scholar in hiding'. And unavailable things are greatly desired. Since Han times, imperial courts routinely summoned recluses to serve, to the extent that some took up reclusion as a shortcut to the court. It is claimed that Zhuangzi was offered the chancellorship of Chu - an offer he declined, since he would rather be a turtle wallowing in mud than an oracle bone enshrined in a royal temple. ${ }^{23}$ Aat Vervoorn argues that Zhuangzi recommends "making oneself invisible by do-

\footnotetext{
$20 \quad$ Ibid., 335-6.

$21 \quad$ Analects 17.7.

22 See Xu Zhen'e 徐震堮, Shishuo xinyu jiaojian 世說新語校箋 (Beijing: Zhonghua shuju, 1984), 1.27 .

23 See zzJS, 17.6o1. Shiji tells a similar story, except to replace the turtle with a bull; see Sima Qian, Shiji, 63.2145.
} 
ing away with any outstanding characteristics or abilities". ${ }^{24}$ Yet a man who hides really well would be invisible to historians too. How, therefore, can the court (or future generations) gain any knowledge of his hiding? Vervoorn blithely dismisses this concern by suggesting that,

[i]n early China, hermits were very important politically as well as socially, hence our main source of information is not what they said about themselves but what others said about them. ${ }^{25}$

The problem is that Vervoorn often confuses fictional truth or didactic functions with facts. As Alan Berkowitz has noted, the stories of 'early authentic recluses' are often half-legends at best. ${ }^{26}$ Thus, we may not take Zhuangzi's recommendation literally, since his teaching has, after all, made him known and useful for centuries. Moreover, Zhuangzi is fascinated by gigantic things - the kun fish, the peng bird, ${ }^{27}$ the gigantic gourd and the expansive Tree-of-Heaven, whose sheer size make them unable to hide. What Zhuangzi offers is rather a discursive repertoire which one could use to reflect upon the relationship between the individual and society.

For Su Shi, who was fond of 'superfluous things' such as garden rocks or fanciful stones, his justification is Zhuangzian. In the following poem, which accounts for his possession of a grotesque garden rock, the silent rock makes an eloquent speech defending its 'uselessness' and argues for its moral grandeur.

咏怪石

家有粗險石

植之疎竹軒

人皆喜尋玩

吾獨思棄捐

以其無所用

曉夕空嶄然

\section{On a Grotesque Rock ${ }^{28}$}

In my house there is a coarse and rugged rock; installed by a veranda, among sparse bamboos. Other people like to visit and appreciate it, I alone want to throw it away.

Since it has no use, showing vainly its distinctive form, dawn to dusk.

Aat Vervoorn, Men of the Cliffs and Caves: the Development of the Chinese Eremitic Tradition to the End of the Han Dynasty (Hong Kong: The Chinese University Press, 1990), 58.

25 Ibid., 17.

26 Alan J. Berkowitz, Patterns of Disengagement: the Practice and Portrayal of Reclusion in Early Medieval China (Stanford: Stanford University Press, 2000), 8-9, 62-3.

27 See zzJs, 1.1-6.

28 Su Shi, "Yong guaishi", sssJ, 48.2605.
} 
碪礎則甲散

砥硯乃枯頑

于繳不可碆

以碑不可鏶

凡此六用無一取

令人争免長物觀

誰知兹石本靈怪

忽從夢中至吾前

初來若奇鬼

肩股何序顏

漸聞䃔硨聲

久乃辨其言

云我石之精

憤子辱我欲一宣

天地之生我

族類廣且蕃

子向所稱用者六

星羅雼布盈谿山
Use it as a chopping board - it would break the knife; grind it into an inkstone - it would drain the ink. Nor can it be worked into an arrowhead to shoot at birds with, or into a stele to be incised upon.

Of the six uses, ${ }^{29}$ it is qualified for none; so why not spare people the view of a superfluous thing?

Who knows that this rock is in fact a genie, which appears suddenly to me in a dream. When it comes, it first looks like a deformed monster; how rugged-looking are his shoulders and thighs! Eventually I hear rolling thunder, and only after a while do I begin to tell his words. He says, "I am the genie of the rock; enraged by your insult, I want to protest. Heaven and Earth have given birth to me, among a widespread and populous race. Those which you, sir, hold as useful in six possible ways,

spread like stars and hails all over valleys and mountains.

傷殘破碎為世役

雖有小用烏足賢

如我之徒亦甚寡 往往挂名經史間

居海岱者充禹貢

雅與鉛松相差肩 處魏榆者白昼語
They are damaged, deformed and broken to serve the world;

despite their petty utility, how do they deserve to be called wise?

Members like me are indeed rare,

but often our names are numbered in the classics and histories.

Rocks on the seaside paramount are listed in the 'Tribute of Yu', as lofty equals with lead and pine. One from Weiyu once spoke in the day,

29 The Śüramgama Sūtra states, "Reverse the flow to preserve the One; let the six senses stay in abandonment” (反流全一六用不行). See T. 19.945.141. Liuyong 六用 is a Buddhist term referring to the application of the six senses, through the eyes, ears, nose, tongue, body and mind. Su Shi borrowed this term to describe all potential uses of rocks, though only four kinds are listed here. 
意欲警惧驕君悛 intending to warn the arrogant king and make him repent.

或在驪山拒強秦 One withheld the powerful Qin, refusing to serve at Mount Li;

萬牛喘汗力莫牽 ten thousand gasping and sweating oxen failed to move it.

或從揚州感盧老 One in Yangzhou once inspired the old poet Lu, 代我問答多雄篇 to produce marvellous poems as fictive dialogues. 子今我得豈無益 震霆凛霜我不遷 雕不加文磨不甞

子盍節䲷如我堅 Haven't you benefited, sir, from your possession of me? Be it thunderstorm or chilly frost, I do not change. I cannot be decorated by engraving or polished by grinding you, sir, should have moral integrity as staunch as mine!

以是贈子豈不伟 Isn't it grand enough to offer this to you? 何必責我区区焉Ｗhy must you charge me on petty causes?" 吾聞石言愧且謝 Hearing what the rock said, I apologise in shame; 醜狀欻去不可攀 駭然覺坐想其語 勉書此詩席之端 the ugly form suddenly departs - I cannot detain it! Awestruck, I wake and sit up, ruminating its words; and respectfully I write this poem on the margins of the sitting mat.

The plot of this poem mirrors the aforementioned story of Craftsman Shi in the Zhuangzi, in which the oak also appeared to the craftsman in his dream, defending its 'uselessness'. At the end, Craftsman Shi similarly woke up and related his dream to his disciples. Emulating Craftsman Shi, Su Shi's poetic persona assumes the voice of a utilitarian. Though other people's appreciation of the rock might attest to its aesthetic values, Su argues that such values alone cannot spare it from being a 'superfluous thing'. Against the charge of utilitarianism, aesthetic argument seems pale, thus the rock has to defend its raison d'être from the perspective of moral symbolism.

If the rock's mockery about the usefulness of its clansmen sounds familiar, its apology is ingenuous. It argues that those that are strange and useless have a better chance of surviving history. Like a learned scholar, it quotes efficacious cases, showing possible non-utilitarian ways in which rocks have historically interacted with humans. The first case was that of the 'strange rocks' on Mt Tai, listed in the Book of Documents among the tributes to King Yu. Commentators have speculated that they were "strange, fine rocks which resembled jade", 30

30 See “Yugong” 禹貢, Shangshu zhengyi 尚書正義, 6.36, ssJzs, 148. 
with no suggestion of their possible use. The second case was from Zuozhuan. In the Spring of 534 BCE, a rock from Weiyu 魏榆 spoke. The King of Jin asked Kuang 曠, the music master, for an explanation. Kuang replied that it was because of the people's complaints about the king's building a new palace. ${ }^{31}$ This case attests to the ethical resonance between man and Heaven. Since a 'useless' rock does not serve the needs of man, it belongs solely to Heaven. The third story refers to a piece of local lore about a tortoise-shaped rock in Lintong County (in modern Shaanxi Province). When the first emperor of Qin died, this rock was fetched from afar to build his tomb under Mt Li; but, suddenly, it would not be moved any farther. So it was abandoned at its present spot. ${ }^{32}$ The fourth rock, lying under the steps of the Xiao family villa in Yangzhou, inspired the poet Lu Tong 盧全 $(795 ?-835)$ to write a series of twenty poems in which the rock is personified as a dialogic counterpart. The rock apologised for being "long neglected, my whole face stained with dark lichen". ${ }^{33}$ In effect, it spoke for the poet himself, a low-ranking scholar thirsty for appreciation. Despite or precisely because of their uselessness, the four rocks represent how the 'useless' are put into ritual, political, moral and literary appropriations.

The eloquent rock continues to portray itself as a moral symbol. It argues that it has benefited the poet in the best way - as a reminder of moral integrity and self-sufficiency. The poet, abashed, respectfully writes down this poem on the margins of his sitting mat. His action emulates that of King $\mathrm{Wu}$, founder of the Zhou Dynasty. It is said that, upon hearing about a ruler's proper behaviour, King Wu wrote mottos on the four margins of his mat, as well as on other utensils and pieces of furniture. ${ }^{34}$ However, unlike King Wu's mottos, which usually have only four characters, Su Shi's long poem certainly would not have fitted in the margins of a sitting mat. The unlikelihood of the last scenario betrays the fictive nature of the whole narrative. If we doubt that the rock could have talked in the poet's dream, the poet's threat to abandon it must have also been rhetorical - his poetic persona plays devil's advocate so that he can write in the rock's defence. The poem betrays conflicting desires on the part of the poet - to conform to the utilitarian principle of austerity and to possess 'superfluous things'. He reconciles these desires by moralising on the rock's presence,

31 See Chunqiu Zuozhuan zhengyi, 44.350, ssJzs, $205^{2}$.

32 The commentator of Su's poem quotes Chang'an zhi 長安志; see sssJ, 48.26o6 n. 10.

33 See “Shi qing ke” 石請客, among “Xiao zhai ersanzi zengda shi ershi shou” 蕭宅二三子 贈答詩二十首, QTS, 387.4373 .

34 See Wang Pingzhen 王聘珍, Dadai liji jiegu 大戴禮記解詁 (Beijing: Zhonghua shuju, 1983), 6.104-5. 
so that the useless finds a shortcut to the highest cultural relevance - not unlike a recluse's high road to court.

\section{Uselessness of the Useful: the Case of Inkstones}

Unlike garden rocks, inkstones were indispensable for the literati. Even so, their career from earlier times to the Song underwent a transition from practical to aesthetic. When they increasingly became collectors' items, they risked being 'superfluous'. For the self-conscious Su Shi, this situation caused uneasiness and begged justification.

The inkstab ${ }^{35}$ did not appear in written documents until the Eastern Han. In Hanshu 漢書 (History of the Han), it is written as yán 研 (usually as a verb, 'to grind'), instead of the later standard form yàn 硯. ${ }^{36}$ A few decades later, the standard form yàn appeared in Shuowen jiezi 說文解字 (An Explication of Written Characters), glossed as 'a smooth piece of rock' (shihua 石滑). ${ }^{37}$ Another early lexicon, Shiming 釋名 (Expounding the Names), simply glossed it as its homonymic verb yán, meaning 'to grind ink and blend it into water'.38 None of the early records shows much interest in its aesthetic features. Only in Tang poetry did inkstabs, particularly those made of stone, begin to acquire class. Poems lovingly described their appearance and recorded instances of them being presented as gifts. ${ }^{39}$ Their aesthetic features received increasing attention, independent of their utilitarian value. Eventually they became objects of erudite connoisseurship. The first record of inkstones was among Wenfang sipu 文房四譜 (Four Records on Studio Paraphernalia), written by the

To be precise, an inkstone is only one type of inkstab (which is a slightly concaved utensil made of stone, clay, metal, jade or lacquerware), against the surface of which an inkcake could be ground to produce ink. Its invention was closely associated with that of ink and brush among Chinese essential writing appurtenances. The early samples of inkstabs were discovered in Qin archaeological sites and are usually plain pieces of stone disk; they might have been in use since earlier antiquity. See Zhonghua guyan 中華古硯, ed. Wang Daiwen 王代文 (Nanjing: Jiangsu guji chubanshe, 1998), XII-XVII.

36 The inkstab appears once in the biography of Xue Xuan 薛宣, “[Xuan] has devised plans even on things as trivial as budget, expenditure, brushes and inkstabs" 下至財用筆研皆 設方略; Ban Gu 班固, Hanshu 漢書 (Beijing: Zhonghua shuju, 1964), 53.3391.

37 Duan Yucai 段玉裁, Shuowen jiezi zhu 說文解字注 (Shanghai: Shanghai guji, 1981), 453.

38 Shiming, 19.2; see Wang Xianqian, Shiming shuzheng bu, 6.19.294-5.

39 See, e.g., Li Qiao 李嶠 (645-714), “Yan” 硯, QTS, 59.707; Liu Yuxi 劉禹錫 (772-842), “Xie Liu Zihou zeng leishiyan” 謝劉子厚贈壘石硯, QTS, 358.4042; Li He 李賀 (790-816), “Yang-sheng qinghua zishiyan ge” 楊生青花紫石硯歌, QTS, 392.4420. 
early Song scholar Su Yijian 蘇易簡 (958-996). Su Yijian's pioneering work was soon followed by a short Yan pu 硯譜 (Record of Inkstones) by Ouyang Xiu, and later the more extensive Yan shi 硯史 (History of Inkstones) by Mi Fu. All three connoisseurs were Su Shi's associates and their hobby must have exerted a certain amount of influence on him.

Connoisseur literature described, appraised and ranked inkstones. In Ouyang's record, the utilitarian criterion, namely the facility of the inkstone in grinding the inkcake to produce ink, is still primary in judging its value. ${ }^{40}$ In comparison, Mi Fu's record shows a combination of criteria at play, including the utilitarian, the aesthetic and the mercantile. It also shows naturalistic interests in enumerating the quality and appearance of inkstones, and taxonomising them according to quarries (even to different pits in the same quarry). Mi Fu's scholarly undertaking was followed by a number of Southern Song authors. Through their endeavours, inkstone connoisseurship was elevated to a field of refined expertise.

Along with the aestheticisation of inkstabs, rock became the predominant material. Though other materials were used in earlier times, only inkstones became collectibles. Su Yijian's record has a passage on Fine Clay Inkstab 澄泥硯, ranked together with three other kinds of inkstones as the most reputed inkstabs under the Tang. ${ }^{41}$ Half a century later, Ouyang Xiu still regarded the Guozhou (now Xin'an, Henan Province) Fine Clay Inkstab as the champion of all inkstabs, since virtually all tiles were better than stone in producing ink (understandable because of the tile's porous surface). He reported that by his own time, however, the technique of producing Fine Clay Inkstab was already lost. ${ }^{42}$

The reason was that, perhaps for a calligrapher, the materiality of the writing tool was as important as its utility. In Sturman's fine phraseology:

[T] he devoted calligrapher handles the inkstone - washes it, grinds the ink in it - and is rewarded with an awakening of the senses in preparation to writing. ${ }^{43}$

The smooth and patterned rock gave a tactile pleasure unmatched by clay. Despite all the carving and decoration, an inkstone appeared to be the product of

\footnotetext{
40 Ouyang Xiu, Yan pu 硯譜, in Ouyang Xiu quanji, 75.1094.

41 Su Yijian 蘇易簡, Yan pu 硯譜, in Wenfang si pu 文房四譜, $s K Q S$, 843.3.6.

42 Ouyang Xiu, Yan pu, 75.1095. The later-revived Fine Clay Inkstone presumably used a different formula; see Wang Daiwen, Zhonghua guyan, IX-X.

43 Sturman, $M i F u, 197$.
} 
minimal human craft; the hue, weight, sound and texture of the natural stone were preserved, which appealed to the visual, aural and tactile senses. Furthermore, every inkstone was unique. As Su Shi bemoaned in an account on the Stone Powder Inkstab 石末硯 (a kind of tile inkstab from Qingzhou [in modern Shandong Province]): although this inkstab was good and was highly esteemed in Tang times, its being manmade made it too easy to acquire; moreover, the same ceramic could be made into many other utensils, a feature that lowered its class. ${ }^{44}$ In contrast, he praised stone as "authentic material" showing "its true nature". Inkstones revealed, rather than hid, their materiality. They were not inexhaustible, which further increased their desirability. For instance, real Duan rock 端石 (from the Duan County 端縣, now Zhaoqing, Zhejiang Province), had become rare in the Song. Red Thread rock (hongsi shi 紅絲石) (from Qingzhou), the most reputed material in Tang times, had already been exhausted by then. ${ }^{45}$ Even more so, some of the finest rocks came from deep water caves, and their acquisition sometimes risked the divers' lives. ${ }^{46}$ All of these factors contributed to the inkstone's rise to stardom.

Ranking and competition appeared with aestheticisation. Song connoisseurs often attempted to rank inkstones. The competition for the championship was mainly between two types of rocks: She rock 隹石 (that is, the Dragon Tail rock [longwei shi 龍尾石] from the She County [now Wuyuan, Anhui Province]) and Duan rock. For a collector, establishing his ranking of inkstones not only demonstrated his expertise and authority, but also raised the reputation and virtual market value of his collection. Su Shi, however, tried to introduce a third champion: Phoenix Beak rock (fengzhou shi 鳳咮石) from Fujian, of which indeed he seemed to be the only lucky owner.

According to Su Shi, Phoenix Beak was a paragon of deceitful appearance: its ugly exterior concealed its peerless virtue; furthermore, its imposter, made of rock from the same river, was identical in appearance but lacked the same quality. Su had written altogether three inscriptions (in addition to two other short notes) to promote the Phoenix Beak. The first inscription aimed to distinguish his Phoenix Beak from one in the possession of Kong Pingzhong 孔平仲 (jinshi 1065), a renowned collector. In the inscription, Su questioned the authenticity of Kong's rock:

I once got mine from the Dragon-Roast Tea garden below Mount Phoenix [now in Jian'ou, Fujian Province], while you got yours from a dark shoal 
by the Sword Ford [now in Nanping, Fujian Province]. The rock clinks harmoniously like music; its texture is solid like gold; its lustre shimmers like jade; it [produces ink] like the fountain below the tongue - such should be its generic features. Is it the case with your rock? If it is the case, though they are from two distant areas, they could still share the same name. Otherwise, in vain, even if your's comes from the same river as my inkstone ${ }^{47}$ their difference is like nine mythic peng $^{48}$ versus one sparrow hawk.

\section{昔余得之鳳凰山下龍焙之間, 今君得之劍浦之上黯黮之灘。如 樂之和, 如金之堅, 如玉之有潤, 如舌之有泉。此其大凡也, 為然為不然? 然也, 雖胡越同名猶可; 不然, 徒與此石同谿而 產，何異於九鵬而一鸇。49}

Su Shi's challenge to the authenticity of Kong's inkstone sounds professional. He first notes the difference between their origins: Su's Phoenix Beak was from a legendary tea garden, Kong's from some dubious shoal. But since the two places are connected by the same river, Kong's might still be authentic, as his stone could have been carried downstream. Thus, Su proposes to examine the quality of Kong's stone in terms of sound, hardness, lustre and its ability to produce and hold ink. If Kong's stone failed this test then it would be worthless: like a sparrow hawk crushed by nine gigantic peng birds.

In the eyes of a connoisseur, mediocrity was worthless. Literature from this period relates that, even for inkstones made of rocks from the same pit, an unblemished inkstone was worth hundreds of times more than a slightly flawed one. ${ }^{50}$ Kong's rock seemed to have failed the test, as suggested by $\mathrm{Su}$ Shi's second inscription. This time, Su aimed to give a defining account on the authentic Phoenix Beak in order to dismiss its imposters once and for all.

Mount Dragon-Roast in the Northern Garden looks like a flying phoenix stooping to drink water. At the position of its beak, there is a certain kind of rock which is pitch dark and has a jade-like texture. In the Xining period [1068-1077], Wang Yi, a native of Taiyuan, made it into inkstone. I named it Phoenix Beak. It is rather limited in production. Some people

\footnotetext{
47 Jian'ou and Nanping are two cities on the Min River 閩江, with Jian'ou being upstream.

48 Peng is a mythic bird that is transformed from the huge fish kun 鯤. See zZJs, 1.2.

49 Su Shi, “Kong Yifu Fengzhouyan ming” 孔毅甫鳳咮石硯銘, sswJ, 19.549.

50 See Mi Fu 米䒾, Yan shi 硯史, in Gujin tushujicheng 古今圖書集成, ed. Chen Menglei 陳 夢雷 (Taipei: Wenxing shudian, 1964), 80.710.
} 
make it from dark shoal rock, which looks extremely similar but is too slippery for the inkcake.

\section{北苑龍焙山, 如翔鳳下飲之狀。当其咮, 有石蒼黑, 緻如玉。 熙寧中, 太原王匵以為硯，余名之曰鳳咮。然其產不富。或以 黯黚滩石為之，狀酷類而多拒墨。51}

Su carefully specified the place of origin, appearance, quality and history of the Phoenix Beak. He revealed that he himself named it. The same story was related by Su Che, who suggested that the Phoenix Beak must have aided Su Shi in writing his commentary on the Book of Changes. ${ }^{52}$ Su Shi once again stressed the danger of imposture. By dismissing imposters of lowly provenance, he reassured the rarity, if not uniqueness, of his own stone.

The third inscription on the Phoenix Beak was a poem. The prosody is deliberately jagged, as it rhymes at the end of every line in the deflected intonation. As the majority of Chinese classical poetry rhymes in even intonations at the end of each couplet, the eccentric phonetic pattern seemed to be calculated to match the uniqueness of the stone. Su Shi again emphasises the unremarkable appearance of the inkstone, whose intrinsic value could only be recognised by a true connoisseur like himself.

\section{鳳咮硯銘}

帝規武夷作茶直

山為孤鳳翔且嗅

下集芝田豚瓊玖

玉乳金沙發靈竇

殘璋斷璧澤而䵢幼

治為書硯美無有

至珍惊世初莫售

\section{Inscription on the Phoenix Beak Inkstone}

His Majesty ruled Mount Wuyi to be his imperial tea garden;

the mountain became a lonely phoenix, flying and stooping to smell.

It lowered to rest in the polypore field and pecked at the dark jade;

below the jade nectar and golden sands, it unearthed a wondrous gem.

Like a relic sceptre or broken jade disk, it shimmered with dark lustre;

when worked into an inkstone, its excellence had no peer.

This supreme treasure dazed the world and at first did not sell;

$51 \quad$ Su Shi, “Fengzhouyan ming bing xu” 鳳咮硯銘並敘, sswJ, 19.550.

$5^{2}$ Su Che, “Fengzhou shiyan ming bing xu”, 鳳咮石硯銘並序, Su Che ji, 18.344. 
黑眉黄眼争妍唒 it had to contest with other black-browed and yellow-eyed.

蘇子一見名鳳咮 Master Su, upon one single glance, named it 'Phoenix Beak';

坐令龍尾羞牛後 it easily reduces the Dragon Tail to the shameful rear of the bull.53

This inscription endeavours to elevate the stature of this inkstone, depicting its origin as a mountain bathed in imperial grandeur and cosmic forces. Jade, gold and water - several elements which, in the first inscription, describe the physical aspects of the inkstone - are used here to promote the supernatural aura of its origin. Such linguistic transference establishes the resonance between the inkstone and its natural abode. Wang Yi, the discoverer of the Phoenix Beak, is not mentioned in this inscription. Instead, its discovery is depicted as a divine incident: the mountain incarnated into a phoenix, which then pecked the "wondrous gem" out of the golden sands. Su Shi, alone credited as its appreciator, rescued the inkstone from obscurity, gave it a striking name and lauded its supremacy at the expense of Dragon Tail - an inkstone of long-established fame since it won the fancy of Li Yu 李煜 (937-978; r. 961-975), the poet-Emperor of the Southern Tang. ${ }^{54}$

In these inscriptions, Su poses with confidence and authority as an inkstone connoisseur. He challenges the expertise of another renowned collector, he defines criteria to judge its authenticity, and he ranks it against other famous rocks. Yet the promotion of Phoenix Beak apparently failed - it was rarely mentioned in later connoisseur literature. ${ }^{55}$ Perhaps it was because there was no such a thing as the 'Phoenix Beak Inkstone' at all. The Southern Song writer Hu $\mathrm{Zi}$ 胡仔 (1095?-1170) made a trip to Mt Phoenix and found no dark rock there. There was not even any pond below the peak from which Su Shi thought his rock had been fetched. The only type of inkstone produced in this area was from Sword Ford, where Kong's rock was found. Hu Zi concluded that Su must have been swindled. ${ }^{56}$

If those crucial differences between Su's 'authentic' and Kong's 'fake' stones were imaginary, Su Shi's expertise in inkstone connoisseurship was perhaps questionable. Nonetheless, his literary reputation made his promotion of

\footnotetext{
53 Su Shi, "Fengzhouyan ming bing xu", sswJ, 19.550.

54 See Hong Shi, Sheyan pu 歌硯譜, in Gujin tushu jicheng, 80.715.

55 It was only mentioned in Li Zhiyan's Yan pu 硯譜, ibid, 80.711. But Li only quoted Su Shi's praise, showing no evidence that he had ever seen it.

$5^{6} \quad \mathrm{Hu} \mathrm{Zi}$, Tiaoxi yuyin conghua, qianji 46.313, houji 29.216-7.
} 
Phoenix Beak well received. His naming of the stone was obviously deliberate, since the Phoenix Beak was in literal parallelism with the Dragon Tail, which he then further mocked as the 'bull's rear', a trope for inferiority. ${ }^{57}$ The naming reveals his ambition to replace Dragon Tail with his own discovery. Were it successful, it would have made his name in the history of inkstone connoisseurship. He reported, with apparent glee, that his unfairness had ignited the fury of the She County folks, who refused to grant him a coveted Dragon Tail. Eventually, a certain gentleman agreed to give him a fine rock on condition that he would overturn the judgment. Su Shi accomplished this task by elaborating on the metaphysical relationship of an inkstone with its human possessor. ${ }^{58}$

\section{黃琮白琥天不惜 Yellow cong or white $g u o^{59}$ - the Heaven never begrudges its treasure;}

顧恐貪夫死懷璧 but it does fear the greedy would die to harbour a precious jade disk.

君看龍尾豈石材 玉德金聲寓於石

Look, sir, the Dragon Tail is no simple rock its jade-like virtue and gold-sounding repute reside in a rock.

與天作石來幾時 與人作硯初不辭

How long has it been a rock for the sake of Heaven?

It does not decline to become an inkstone on behalf of man!

詩成鮑謝石何與 When a marvellous poem is written, ${ }^{60}$ what has the rock helped?

筆落鍾王硯不知 When the brush falls like possessed, ${ }^{61}$ the inkstone is oblivious!

錦茵玉匣俱塵垢 A brocade mat or a jade case - these are but dusts and stains;

擣練支牀亦何有 used to pound silk or to support a couch - it cannot care less!

57 In Zhanguoce 戰國策, Su Qin 蘇秦 tried to persuade the King of Han to join their ally against Qin by quoting a proverb. "Rather be the beak of a rooster than the rear of a bull" 寧爲雞口不為牛後; see Zhu Zugeng 諸祖耿, Zhanguoce jizhu huikao 戰國策集注匯 考 (Nanjing: Fenghuang chubanshe, 2008), 26.1355.

$5^{8}$ Su Shi, “Longweiyan ge bingyin” 龍尾硯歌並引, sssJ, 23.1235-6.

59 Both cong and guo are ritual jade vessels. Cong is in the shape of a tube with a circular inner hollow and a square outer shape. Guo is in the shape of a tiger.

60 'Bao' and 'Xie' refer to Bao Zhao 鮑照 (414?-466) and Xie Tiao 謝朓 (464-499) respectively, used here as metonymy for poetry of the highest quality.

61 Zhong and Wang refer to Zhong You 鍾缶 (151-230) and Wang Xizhi 王羲之 (321-379) respectively, used here as metonymy for calligraphy of the highest quality. 
況瞋蘇子鳳咮銘 Not to say the fury at Master Su's inscription on the Phoenix Beak,

戲語相嘲作牛後 which jokingly mocks it as the bull's rear.

碧天照水風吹雲 The blue sky shimmers on the water; the wind

disperses the clouds;

明窗大几清無塵 a bright window, a broad desk, all clear of dusts.

我生天地一閑物 “I was born between Heaven and Earth as an idle thing;

蘇子亦是支離人 Master Su is also a man at odds.

麀言細語都不擇 He does not choose between vulgar or refined words,

春蚂秋蛇隨意畫 and let the ink spray at will into spring earthworms or autumn snakes.

願從蘇子老東坡 I am willing to follow Master Su to grow old on the East Slope.

仁者不用生分別 Oh, the man of benevolence, make not distinctions!"

In his poem, Su Shi first reassures the indifference of Heaven to treasures, which is valued only by man. A stone is similarly insouciant to its destiny in the hands of man. The verb 'to reside' ( $y u$ 寓) suggests contingency. The name 'Dragon Tail' is an arbitrary signifier attached to the stone, alluding to those virtues which happen to 'reside' in it. A stone shows no intentionality in choosing its fate. If no treatment at human hands matters to the stone, why should it care about a joke? Su then envisions his treatment of the inkstone: he will put it in a refined studio and respect it as a worthy companion; he will not fashion his artistic style to match the price of the inkstone, but will simply write spontaneously. His casualness will show that his mind is not hindered by the inkstone's preciousness - even though he covets it. His desire for the inkstone, however, is redefined as mutual attraction. He projects himself as "a man at odds [with the world]", just like the inkstone, "an idle thing". Their kindred spirit qualifies Su Shi to 'host' the inkstone in his studio, and this desire is voiced by the inkstone itself at the end of the poem.

Su Shi used the rhetoric of friendship to justify his material possession. The reader may be tempted to ask: if the inkstone is void of intentionality, how can it show any preference to a certain owner, even if this owner is Su Shi? The rhetoric of non-intentionality and that of kindred attraction contradict each other. As further observed below, in cases concerning the transactions of rocks, these two sets of rhetoric are used alternatively for different ends. The rock is a mirror reflecting human desires. 


\section{Poetry on Exchange: Rocks in Literati Economics}

The comparison of an inkstone to a recluse is elaborated in a fictive biography of an inkstone, "Biography of Luo Wen, the Lord of Ten Thousand Stones".62 The authenticity of this essay has been debated since the Southern Song, but editors of Su Shi's prose anthologies have generally included them. ${ }^{63}$ In this playful account, which emulates the style of Shiji, a Dragon Tail inkstone is personified as a literatus, Luo Wen 羅文. At first, he is a recluse hiding in the mountain. He is then summoned to the court of Han Wudi 漢武帝 (156-87 BCE; $r$. 141-87 BCE), serves in a series of imperial cultural enterprises, is later charged with corruption, and eventually dies in disgrace. Even if Su Shi did not write this piece, its broad acceptance into his anthology suggests that its style and content are credible enough to be considered as his work. Su Shi's predilection for collecting inkstones and personifying them as scholars, especially recluses, further lends credibility to its claim to authenticity.

In this account, the inkstone's fate in the commodity sphere becomes a parable for the literatus' fate in the bureaucratic system. Both have lost their independence and are owned by a larger economic or socio-political network. Singularity is the most valuable asset for a collector's item and a scholar alike. Their tradability, however, implies dispensability and commonality. They could now be traded for something else, be it cash or power. To retain their claim to singularity, the stigma of commoditisation must be washed away as soon as they pass the transformative stage of identity. As Arjun Appadurai argues,

[they belong to] the category of objects whose commodity phase is ideally brief, whose movement is restricted, and which apparently are not 'priced' in the way other things might be. ${ }^{64}$

Such singular items phase "in and out of the commodity state". ${ }^{65}$

62 Su Shi, “Wanshi-jun Luo Wen zhuan” 萬石君羅文傳, sswJ, 13.424-7.

63 See Luo Ning 羅寧 and Wu Lixia 武麗霞, "Su Shi Su Che wenzhuan shulun: jianlun Beisong wenzhuan” 蘇軾蘇轍文傳述論一兼論北宋文傳 (Paper presented at the 18th International Su Shi Studies Conference, Leshan, 2013. Printed in the conference anthology), 588-9o.

64 Arjun Appadurai, “Introduction: Commodities and the Politics of Value", in The Social Life of Things, ed. Appadurai (Cambridge, UK: Cambridge University Press, 1986), 24.

65 Ignor Kopytoff, "The cultural biography of things: commoditization as process", in ibid., 64-91. 
Aestheticisation was thus accompanied by the constant anxiety over possession and commoditisation. Rocks are 'superfluous things' which are particularly tradable: they are unique, last almost forever, never lose their value through repeated use, and are precious enough to be traded or sent as gifts. Moreover, both garden rocks and inkstones play the role of elegant companion in a scholar's life. Their value increases with every poem or colophon written about them by their famous owner. Poetry plays yet another function: it defines their identity. Since commoditisation carries a stigma for a collector's item, these objects should pass the commodity phase as quickly as possible or the owner has to pretend that they were never commodities at all.

The transaction of objects implicated their possessors in a complex social network of exchanges. Every form of exchange - monetary trade, barter or gift exchange - implied a different set of social relations and economic mechanisms. In Su Shi's time, monetary exchange and even barter were seldom recorded in literature. Of all the inkstones and strange rocks that Su Shi collected, he mentions price only once: one hundred silver ingots for a rock he failed to buy. ${ }^{66}$ The price for successful transactions was never mentioned. Monetary exchange or barter might be the de facto dominant forms of exchange, but such cases rarely, if ever, found their way into literature of lofty register.

In contrast, Su Shi often talked about rocks as gifts. Gift giving, as Marcel Mauss' seminal study argues, is based on the principles of reciprocity and aims to achieve social solidarity. The gift-sender enters a social network, anticipating immediate or future reciprocation from the gift recipients. As Mary Douglas explains in the foreword to The Gift:

[E] ach gift is part of a system of reciprocity in which the honour of giver and recipient are engaged. [...] The system is quite simple: just the rule that every gift has to be returned in some specified way sets up a perpetual cycle of exchanges within and between generations. ${ }^{67}$

Marcel Mauss argues,

[that the Chinese civilisation] acknowledges the indissoluble link that binds everything to its original owner. [...] Though the thing passes on, even if it is consumable, the alliance that has been contracted is no

66 See Su Shi, “Huzhong Jiuhua shi” 壼中九華詩, sssJ, 38.2047-8.

67 Mary Douglar, Foreword to Mauss Marcel, The Gift: the Form and Reason for Exchange in Archaic Societies, trans. W.D. Halls (New York and London: W.W. Norton, 1990), viii. 
momentary phenomenon, and the contracting parties are deemed to be in a state of perpetual dependence towards one another. ${ }^{68}$

The act of sending a gift proves the giver to be not independent of his society, but enmeshed in a "perpetual cycle of exchanges". These gifts thus become tokens of alliance.

What further distinguishes the literati's exchanges is the ubiquity of poems written to accompany each step. Unlike normal social poetry - which is a discourse machine almost automatically producing poems for occasions, using a repertoire of decorous dictions - these poems are unique and play vital functions in these exchanges. In each exchange, it was poetry that proposed, recorded, interpreted, facilitated, obstructed or concluded the transaction. The poems were further necessary to weaken or disguise the exchanges as market behaviour. As Mauss and Douglas argue, a gift exchange does not require reciprocity of equal monetary value or expect to be concluded after a single transaction. It aims instead to set up "a perpetual cycle of exchanges" to enhance social solidarity. For this purpose, a reciprocated poem was even better than a reciprocated gift, because social decorum required that when the gift sender received a poem from the gift recipient, he must compose yet another poem in response (usually using the same rhyming words). A poem accompanying or responding to a gift would thus trigger at least one other cycle of poetic exchange, continuously generating social solidarity. Lastly, and most importantly, it was a public display with written records which announced their liaisons to a present or future republic of letters. Poetry helped define the nature of their exchange and shaped the way in which the author wanted it to be understood. Due to the last feature, it justified the gift exchange, distinguished it from downright bribery, and created the camaraderie of shared ethical and aesthetic standards.

\section{Gift Exchanges with the Two Fans}

In 1092, Su Shi sent a set containing a 'moon-rock inkstone and screen' to Fan Bailu 范百祿 (1030-1094), and a 'starry inkstone' to his nephew Fan Zuyu 范祖禹 (1041-1098). ${ }^{69}$ Bailu was then the Vice Director of the Secretariat

68 Ibid, $63-4$.

69 See “Shi jin yi 'yueshi yan ping' xian Zigong Zhongshu gong, fu yi ‘hanxingyan' xian Chunfu Sijiang [...]” 軾近以月石硯屏獻子功中書公復以涵星硯獻純父侍講 [...], sssJ, 36.1924-6. The editor Kong Fanli has punctuated between zhongshu and gong, which suggests that Bailu sent the 'starry inkstone' to Zuyu. However, the rest of the title, the poem itself and the follow-up poem all strongly suggest that it was Su Shi who sent the 
Chancellery (Rank 2a), ${ }^{70}$ while Zuyu, Expositor-in-Waiting (Rank 7a), was a tutor to the young Emperor Zhezong. Zuyu's office was lower in rank, but it was highly prestigious and influential. ${ }^{71}$ Su Shi had been newly summoned back from his provincial tenure as the Governor of Yangzhou. Due to the patronage of the Empress Dowager Xuanren, grandmother of the Emperor, he was successively appointed to Minister of War (the ninth to the tenth month of 1092; Rank 2b), and then to Minister of Rites (the eleventh month of 1092 to the eighth month of 1093; Rank 2b).

Ranks mattered. Their similar status and political loyalty suggested that $\mathrm{Su}$ Shi's gift-sending was to strengthen their collegiality and political alliance. There was, however, an imbalance in the gifts. Bailu received a stone screen and an inkstone, while Zuyu only an inkstone. Since Bailu's rank was higher, Zuyu probably saw it as snobbery. Thus, when Bailu sent Su Shi a poem as a token of gratitude, Zuyu kept his silence. Su Shi must have sensed Zuyu's dissatisfaction. He then matched Bailu's poem in rhyme and sent a copy of the poem to Zuyu, together with a stone screen, urging his response. Zuyu finally sent him a poem, acknowledging his gratitude for both the inkstone and the screen. Su Shi matched Zuyu's poem in response, concluding this gift-poetry exchange cycle. ${ }^{72}$

Su Shi's first poem addresses both Fans. It describes the patterns on the rocks and compares them to heavenly bodies descending on the literatus' desk. Looking at them, their possessor will "clear his eyes" and find "the world is like foam and shadow;/ there is no need to distinguish the big from the small, falsehood from the truth". ${ }^{73}$ The names of the stones are sublimated into symbolisms of transcendence, and their existence in a studio would supposedly remind the scholar of a world of permanence above this human world of relative values.

'starry inkstone' to Zuyu. Thus gong should follow zhongshu as a respectful epithet to Bailu, who was older and more senior in rank than Su Shi.

70 The ranks of the positions follow Gong Yanming 龔延明, Songdai guanzhi cidian 宋代官 制辭典 (Beijing: Zhonghua shuju, 1997), since Charles Hucker's A Dictionary of Officials Titles in Imperial China (Taipei: Southern Materials Center, 1985), whose translation of the positions are otherwise followed in this book, sometimes fails to reflect the official institutional reform in 1080 .

It is said that Su Shi called Fan Zuyu "the best imperial expositor of our time", see "Huayang xuean” 華陽學案, in Huang Zongxi, Songyuan xue'an, 21.76.

See Su Shi, “Ciyun Fan Chunfu 'hanxingyan' “yueshi fenglin ping shi” 次韻范純父涵星硯 月石風林屏詩, sssJ, 36.1926-8.

73 See “Shi jin yi ‘yueshi yan ping' xian Zigong Zhongshu gong [...]” 軾近以月石屏硯獻子 功中書公 [...], sssJ, 36.1925 . 
Zuyu, an austere and dogmatic Confucian, might have read Su's poem as too Buddhist. Thus, in his response poem he repeated the comparisons of these rocks to heavenly bodies, but gave no hint of reference to impermanence or illusoriness. Su understood Zuyu's disapproval, and in his response poem there were no references to popular Buddhist notions. He instead alluded to another kind of transcendence with which Zuyu was more conformable - disengagement with worldly affairs. ${ }^{74}$

In this cycle of exchanges, as Bailu and Zuyu's different responses showed, poetry was first of all a signal from the recipient confirming his satisfaction with the gift. Second, it interpreted the transaction and engaged the participants in a dialogue through which they reached an agreement on the interpretation of an object. Only when the recipient was satisfied, not only with the gifts but also with the interpretation, was the cycle concluded.

\section{A Barter of Inequity}

The second form of exchange is object for object, or barter. Appadurai defines barter as "the exchange of objects for one another without reference to money and with maximum feasible reduction of social, cultural, political, or personal transaction costs". ${ }^{75}$ It is presumably the most straightforward type of exchange. But, in the case to be examined below, the situation was far from simple because of the role of poetry, and because the proposed bargain seemed unfair.

This exchange took place in 1084 between Su Shi and Zhang Jin 張近 (d.u.), an official known for his courage and insight. Zhang was not among Su's close social circle. The exchange began with Su Shi requesting Zhang's 'Dragon Tail baby-rock' inkstone. The 'baby-rock' (zishi 子石) was believed to be the stony core formed within a big rock, like a foetus inside a pregnant body. It was extremely rare. Su Shi proposed to exchange it with a bronze sword. ${ }^{76}$ Even though Zhang might have been an aficionado of swords, a nondescript sword for a rare inkstone would have been a hard sell. Pre-empting Zhang's reluctance, $\mathrm{Su}$ sent a poem along with the sword to explain his proposal: ${ }^{77}$

74 See Su Shi, "Ciyun Fan Chunfu 'hanxingyan' "yueshi fenglin ping shi”, sssJ, 36.1926-8.

75 Appadurai, "Introduction: Commodities", 9.

76 Or perhaps a pair of bronze swords. Prior to this exchange, Su Shi had once got drunk in the house of Guo Xiangzheng 郭祥正 and painted bamboos and rocks on his walls. Guo gave him a pair of bronze swords in thanks. See "Guo Xiangzheng jia zui hua zhushi bishang [...]” 郭祥正家醉 畫竹石壁上 [...], sssJ, 23.1234-5. It might be Guo's swords that Su Shi used to trade Zhang's inkstone.

77 Su Shi, “Zhang Jin Jizhong you Longwei zishi yan yi tongjian yi zhi” 張近幾仲有龍尾子 石硯以銅劍易之, $s S S J, 23.1237-8$. 
我家銅劍如赤蛇 君家石硯蒼璧橢而窪 君持我劍向何許 大明宮裏玉佩鳴衝牙

我得君硯亦安用 雪堂窗下爾雅箋蟲蝦

二物與人初不異

飄落高下隨風花 萠緱玉具皆外物

視草草玄無等差

君不見

秦趙城易璧

指圖睨柱相矝誇
My bronze sword is like a vermilion snake, your inkstone, a concaved, oval, dark jade disk. Where would you go with my sword in hand? in the Palace of Great Light, it clings with the jade tusk. ${ }^{78}$

What would I do, when I acquire your inkstone?

Below the window of Snow Hall, I comment on the insects and fish in Erya. ${ }^{79}$

The two things do not choose their human companions;

like flowers scattering high or low with the wind. A straw-stringed or jade handle is only external to the sword;80

writing a court edict or a private work is equal to the inkstone. ${ }^{81}$

Don't you see, sir,

the Qin once traded cities for a jade disk from the Zhao?

Those map-pointers and pillar-lookers competed their ruse. ${ }^{82}$

78 “The Palace of Great Light" 大明宮 was a Tang Dynasty imperial palace built in 662. "Tusk" (chongya 衝牙) refers to the pointed tip placed on a jade pendant, described in the Book of Rites; see Liji zhengyi 禮記正義, 30.254, ssJzs, 1483.

79 "Commenting on the insects and fish (chongyu 蟲魚) in Erya" is a fixed expression for meticulous philology, as used by Su Shi in “Guo Wen Jue Xiangong fang” 過文覺顯公房, ssSJ, 25.1345. Here, Su Shi has changed it to "insects and shrimp" for the sake of rhyme. I have replaced "shrimp" again with "fish", since "shrimp" seems rather awkward when the rhyme disappears in translation.

80 Kuan 萠 means straw-string; hou 緱 means the handle of a sword. This term comes from the biography of Lord Mengchang 孟嘗君, where Feng Huan 馮驩, a low-ranking scholar, possessed such a sword. Its shabby handle bespoke its owner's lack of fortune. See Sima Qian, Shiji, 15.2359.

81 "Supervising imperial drafts" refers to Sima Xiangru, who was said to be commissioned for this task when Emperor Wu wanted to send anything to Liu An, the King of Huainan, as he was in such awe of Liu An's literary reputation; see Liu An's biography in Ban Gu, Hanshu, 14.2145. "Drafting Taixuan", here translated as "drafting in private", refers to Yang Xiong 揚雄 (53 BCE-18), who had composed this work in private; see Yang Xiong's biography, ibid., $57 \cdot 3565$.

82 It is said that the Qin once wanted to trade fifteen cities with the Zhao for "Mr. He's Jade Disk” (Heshibi 和氏璧). Aware of the Qin's possible treachery, Lin Xiangru 鹳相如 was commissioned to take care of the jade. When Lin found out in the Qin court that the King 


\begin{tabular}{|c|c|}
\hline $\begin{array}{l}\text { 又不見 } \\
\text { 二生妾換馬 }\end{array}$ & $\begin{array}{l}\text { Don't you also see, } \\
\text { the two scholars once traded a concubine for a } \\
\text { horse? }\end{array}$ \\
\hline 驕鳴哆泣思其家 & $\begin{array}{l}\text { The horse neighing, the girl sobbing, both } \\
\text { longing for home. }{ }^{83}\end{array}$ \\
\hline $\begin{array}{l}\text { 不如無情兩相與 } \\
\text { 永以為好 } \\
\text { 譬之桃李與瓊華 }\end{array}$ & $\begin{array}{l}\text { Better give each other a non-sentient thing, } \\
\text { as tokens of eternal friendship - } \\
\text { like peach and plum in exchange for a jade } \\
\text { flower. }^{84}\end{array}$ \\
\hline
\end{tabular}

Unlike in a market place, Su Shi does not begin his proposal by calculating the price. Instead, he depicts the niceties of both objects with studied fairness. Notably, he uses grandiloquence in projecting Zhang wearing the sword in royal service, whilst downplaying himself as engaging in pedantic works. This rhetorical manoeuvre appears to be calculated to offset Zhang's negative response to this proposal. Su Shi then expatiates upon the indifference of insentient objects to their destinies in human hands. It implies that the obsession about possession is totally subjective, unjustifiable from the point of the view of the object. Xiaoshan Yang has also observed the rhetoric on the independence of the objects, but he interprets it as an "anticlimactic declaration" and does not consider it relevant to the transaction. ${ }^{85}$ In my opinion, however, the unbelongingness of objects plays an essential function in Su's proposal. Since an object is transcendental to human obsession, it is emotionally detached from changing hands and brings no intrinsic mark of ownership with it. In this way, the exchange does not concern the object but only the parties involved in the exchange. Furthermore, an unbelonging object is external to the human value system, thus the exchange should not be mercantile. So what is the nature of their exchange? Su lists a few historical examples of exchanges only to contradict them. The exchange between the Qin and the Zhao involved an excessive imbalance of power and caused devastating distrust. That between Pei

of Qin was likely to break the promise, he retrieved the jade with the excuse of pointing out a flaw. He held it, looking askance at a pillar, threatened to commit suicide and smash the jade. The King thus pointed at the map, pretending to show him the fifteen cities in exchange. Mistrusting him, Lin devised another ruse and finally brought the jade back to the Zhao. See Lin Xiangru's biography in Sima Qian, Shiji, 81.2439-41.

83 This couplet refers to the exchange between Pei Du 裴度 (765-839) and Bo Juyi, when Pei sent Bo a horse, together with a poem requesting Bo's beloved concubine. This incident has been analysed in Xiaoshan Yang, Metamorphosis, 160-97.

84 Reference to "Mugua" 木瓜 (Mao 64), see Maoshi zhengyi, 3·3.59-6o, ssJzs, 327-8.

85 See Xiaoshan Yang, Metamorphosis, 171. 
$\mathrm{Du}$ 裴度 $\left(765^{-8} 39\right)$ and Bo Juyi traded two sentient beings and caused too much pain. Su suggests that, unlike these two cases, they should exchange tokens of friendship (as described in the Book of Odes). Ironically, the last line exchanging "peach and plum" for "a jade flower" - implies an imbalance of monetary value after all, and therefore contradicts Su Shi's earlier effort to project the two objects as equal. Thus, Su Shi, in effect, admits the unfairness of his proposal and appeals instead to Zhang's friendship to accept his offer.

Zhang sent Su's sword back, together with the inkstone and a poem. This poem, which is no longer extant, would otherwise have explained his action. Possibly, he was upset by Su's proposal. In fact, despite its euphemism, Su's poem did not justify Su's having the inkstone and Zhang the sword, except to imply that Zhang would be dignified by the sword in court attendance, while Su needed the inkstone for his scholarly work. In a society prizing cultural enterprise above political ambition and military feat, Su's implication was close to insult. Zhang was thus obliged to reverse the situation by emphasising his lack of concern about his bright prospects, as symbolised by the sword. He further showed his magnanimity by sending the coveted stone, and showed his goodwill by writing a poem.

This was how Su Shi seemed to have understood Zhang's action. Thereupon he sent Zhang yet another poem with the sword. The second poem compared Zhang to roaming warriors, frustrated and eager to employ their talents for some noble cause. ${ }^{86}$ As no more poems were written on this exchange, we may infer that Zhang accepted the sword, together with the final explanation, since it had expunged the unworthy hint of wealth or power, and instead associated the sword with integrity, royalty and heroism.

The exchange of poetry helped define the material exchange. Su's first poem hesitated between barter and gift exchange. Zhang's response clarified the ambiguity and declared it to be a gift exchange. By sending a poem, which conventionally invited another poem in response, he also suggested his inclination to prolong their cycle of exchanges. Su Shi confirmed his equal willingness to enhance their social solidarity by responding. He was reluctant however to be the sole recipient of material gain in this exchange, which would project his motivation as exploitative. So he sent the sword again, underlining his sincerity, and offered a fresh interpretation of the sword. When Zhang finally accepted the sword, the initially proposed barter had been transformed, through poetry, into an exchange of gifts. 
III

\section{A Scuppered Exchange}

If $\mathrm{Su}$ Shi was able to acquire a rock with his poems, he could also use them to keep a rock. In the third case, to be examined below, the other party to the exchange was Wang Shen 王詵 (1048-?), ${ }^{87}$ the husband of a princess and uncle of the young Emperor Zhezong. To Su Shi, Wang was a friend and ally. When $\mathrm{Su}$ Shi was prosecuted for his poetry in 1079, Wang Shen was among those implicated and exiled. Thus, despite Su Shi's reluctance to grant Wang's request, he knew he could not displease a powerful friend. He used poems to scupper the Wang's proposal of an exchange, politely.

The exchange began with Wang sending Su Shi a short poem in 1092, asking to 'borrow' his Qiuchi rocks, named after a legendary mountain resided by earthly immortals. ${ }^{88}$ Of this pair of rocks, one was green, like a mountain range pierced with a tiny hole, and the other was white and smooth as a mirror. ${ }^{89} \mathrm{Su}$ acquired them in the spring of 1092 and saw them as a symbol of the divine mountains in his Sichuan hometown. As his favourite rocks, he depicted them in multiple poems and colophons. So Su Shi begrudged sending Wang the rocks. Instead, he sent Wang a long poem, expressing his concern that Wang, being the powerful party, would seize them. ${ }^{90}$ Three of their common friends matched Wang Shen's poem and gave their opinion: Qian Xie 錢妿思 (1034-1097) and Wang Qinchen 王欽臣 (d.u.) both tried to dissuade Wang; Jiang Zhiqi 蔣之奇 (1031-1104) initially supported Wang but, upon seeing the rocks, withdrew his support. ${ }^{91}$ Having rallied support from the mediators, $\mathrm{Su}$ Shi proposed to trade the rocks for a celebrated horse painting, by the Tang painter Han Gan 韓幹 (fl. eighth century), in Wang's possession. It was not uncommon for Su Shi to regard strange rocks and works of art as having the same market value. In 1085, he had already traded a painting of his own for an unusual garden rock. ${ }^{92}$ Su's opinion was, however, not necessarily shared by

87 This exchange has also been examined in Xiaoshan Yang, Metamorphosis, 179-95, as well as in Ronald Egan, The Problem of Beauty (Cambridge. Mass.: Harvard University Asia Center, 2006), 226-32. Yang's major argument is that Su's possessiveness motivated his resourceful use of poetic rhetoric to overcome the unequal power in the relationship. Egan concludes from the exchange that Su Shi's ideal of non-possessive possession is a state of mind, not an objectively observable behaviour. Nevertheless, I have here provided a new translation and argument for this poem for a different agenda.

88 See ch. 4, 150-1. More on this pair of rocks, Egan, Beauty, 220-4.

89 Su Shi, “Shuangshi” 雙石, sssJ, 35.1880.

90 See "Pu suocang Qiuchi-shi xidaizhibao ye [...]” 僕所藏仇池石希代之寶也 [...], sssJ, 36.1940-2.

91 See “Wang Jinqing shishi yu duo haishi [...]" 王晉卿示詩欲奪海石 [...], sssJ, 36.1945

92 See “Shu huabi yishi” 書畫壁易石, ssWJ, 70.2214. 
Wang Shen, a painter and collector, who was also grudging. To break the deadlock, Qian Xie proposed to take both the rocks and the painting into his own custody, while Jiang Zhiqi proposed to destroy both. Unwilling to accept either proposal, Su Shi wrote the third poem in the sequence, using his sophistry to keep the rocks. ${ }^{93}$

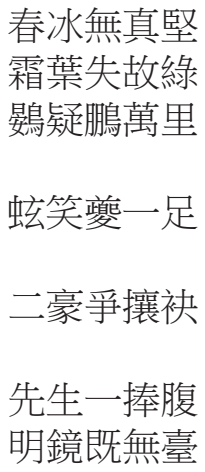

春冰無真堅 霜葉失故綠 鷃疑鵬萬里

\section{蚿笑硨一足}

\section{二豪爭攘袂}

先生一捧腹 明鏡既無臺
The ice in spring does not have true solidity; the frosty leaves lose their former green.

A quail may doubt if the huge peng can fly ten thousand $l i{ }^{94}$

and a millipede laughs at the monster kui for being one-legged. ${ }^{95}$

When two gallants fight, grabbing at each other's sleeve,

the master holds his belly, roaring in laughter. ${ }^{96}$

Since the bright mirror has no pedestal, ${ }^{97}$

93 See “Shi yu yi shi yi hua Jinqing nanzhi [...]” 軾欲以石易畫晉卿難之 [...], sssJ, 36.1947.

94 In the Zhuangzi, when the mythic peng wanted to fly to the southern sea, a quail laughed at its ambition, since it seemed to the quail that flying a few feet above the bushes was high enough. See zzJs, 1.2.

95 According to Shanhaijing 山海經, kui was a monster living on a mountain in the Eastern Sea; it looked like a dark bull without horns and only had one leg; see Yuan Ke 袁珂, Shanhaijing jiaozhu 山海經校注 (Shanghai: Shanghai guji chubanshe, 1985), 14.361. In the Zhuangzi, kui once asked the millipede how it managed to handle its thousands of legs, since dealing with a single leg was troublesome enough; see zZJS, 17.592-3. Su Shi used this allusion, but put it in such a way that the millipede laughed at kui.

96 In his "Eulogy on the Virtues of Wine" (Jiudesong 酒德頌), Liu Ling 劉伶 (221?-300) called his persona "Master Great Man" (Darenxiansheng 大人先生), whose sole dedication was to drink. A young aristocrat and a country gentleman heard of his behaviour and started arguing about its acceptability. The argument ended in a brawl. The master, however, did not care about their debate and kept drinking in a state of happy transcendence. See Liu Ling's biography in Fang Xuanling, Jinshu, 49.1376.

97 According to the legend, when the fifth patriarch of Chan lineage, Hongren 弘忍 (6o1675 ), was looking for his successor, his primary disciple Shenxiu 神秀 (6o6-706) demonstrated his understanding by a gatha, comparing his body to the pedestal of a bright mirror (the mind) which should be frequently dusted. Huineng 惠能 $(638-713)$, who would later become the sixth patriarch, retorted that the bright mirror did not originally have a pedestal, so there was no need to brush off the dust. See Jingde chuandenglu 景德 傳燈錄, T no. 2076, 51.222c. 
淨瓶何用歳

盆山不可隱

畫馬無由牧

聊將置庭宇

何必㶳溝瀆

焚寶真愛寶

碎玉未忘玉

久知公子賢

出語者年伏

欲觀轉物妙

故以求馬卜 維摩既復捨

天女還相逐 授之無盡燈 照此久幽谷 定心無一物 what's the purpose of kicking over the clear-water pitcher? ${ }^{98}$

A miniature mountain is no place for reclusion, just like a painted horse cannot be herded. Leave it for now in my courtyard, sir why must you discard it into a ditch?

He who has burnt a treasure is truly attached to the treasure;

he who has smashed a jade never forgets the jade.

I have long known the young lord's wisdom;

his words could lower even his seniors' heads.

I wanted to observe the marvel of transforming things;

so I tested him by requesting the horse painting. Yet even though Vimalakirti had abandoned the sylphs,

the sylphs still lingered by his side..$^{99}$

He gave them an endless burning lamp, to illuminate their long darkened valleys of wisdom. If the mind is settled, with nothing in hindrance,

98 When Baizhang Huaihai 百丈懷海 (749-814) intended to transmit the orthodoxy of his lineage to Master Weishan Lingyou 溈山靈祐 (771-853), a senior monk, Hualin 華林, protested on the grounds of his own seniority. Baizhang offered to test his understanding by pointing to a pitcher of clear water and saying, "It shall not be called a clear-water pitcher". Hualin responded, "Then it shall not be called a wooden stake either". Baizhang asked Lingyou the same question, and Lingyou responded by kicking the pitcher over. So Lingyou won the contest and became next in succession. See Tanzhou Weishan Lingyou chanshi yulu 潭州溈山靈祐禪師語錄, T no. 1989, 47.577b.

In Vimalakìrti Sütra, the demon king once assumed the form of Sakyamuni Buddha and led twelve thousand sylphs to tempt a bodhisattva, insisting on leaving the sylphs with him to be his household maids. The bodhisattva, unable to refuse the command, was rescued by Vimalakirti, who recognised the demon king and proposed to take the sylphs for himself. The demon king agreed in fear, and Vimalakirti preached to the sylphs, teaching them to accept the joy of dharma, instead of following their corporeal desires. The sylphs, now transformed, refused to return to the demon's palace. When the demon challenged Vimalakīrti for keeping the sylphs in his company, he replied that he had already abandoned them, but that they had chosen to stay by his side. In the end, he persuaded the sylphs to return to the demon's palace and convert their fellow servants, since they had already acquired "the endless burning lamp". See Weimojie suo shuo jing 維摩詰所說經, T no. $475,14.543$ b. 
法樂勝五欲

三峨吾鄉里 萬馬君部曲

臥雲行歸休 破賊見神速 the joy of dharma will conquer the five corporeal desires.

Below the lofty three peaks of Emei is my hometown; ${ }^{100}$ while the ten thousand horses are subject to your command.

I will soon return, retiring among the clouds;

and you should vanquish the enemies at magic speed.

Su Shi begins by depicting the impermanent nature and limited vision of earthly things. Only limited beings will brawl over petty moral issues (like abstinence from wine), while a Master Great Man will only laugh at their quarrels. It is because he understands that, above the world of contingency and relativity, there is a world of permanence, symbolised by the bright mirror or the clear-water pitcher. These things are indifferent to human treatment and remain self-sufficient. Certainly they are only symbolic of the real things which one desires, but since they are already in one's possession, why must the owner dump them just to prove his non-attachment? For Su Shi, strenuous effort to attain spontaneity is itself a hindrance to the mind. Su Shi uses this argument to first overcome Jiang Zhiqi's proposal to destroy both treasures; then he comes to terms with Wang Shen's desires.

In praising Wang's wisdom, Su puts him on a pedestal. Then Su Shi relinquishes his own request for Wang's painting, saying that his sole purpose was to test Wang's marvellous wisdom as the master and not the slave of 'things'. He does not chide Wang and claim that he failed the test. On the contrary, he praises Wang for being another Vimalakirti who has abandoned the sylphs, though they follow him anyway. Su develops the reference to Vimalakïrti for a few couplets, arguing for the supremacy of the joy of dharma over the gratification of corporeal desires. It implies that painting provides Wang with the joy of dharma. By first challenging Wang and then exonerating him from the charge, $\mathrm{Su}$ also defends his own possession of the rock as stemming from the joy of dharma.

If, as in the case of Zhang Jin, the above argument still did not justify why either should own his particular object, Su then gives his final reason: the Qiuchi rock reminds $\mathrm{Su}$ of his hometown, so he is in emotional need of its company; the horse painting reminds Wang of heroic warfare, which is his secret ambition (Wang was the grandson of a general). Artistic forms, which have

100 Strictly speaking, Meishan is about seventy kilometers away from Mt Emei, but in the Song it belonged to the Leshan 樂山 municipal administrative area, which included Emei. 
earlier been disclaimed as illusory resemblances, are redeemed as symbols of the real things. The "three peaks of Emei" refer both to the real mountain and to the Qiuchi rocks; similarly, the "ten thousand horses" refer to the real warhorses and the painted horses. The possession of an object is once again justified for the object's symbolic value and for its claimed spiritual kinship with its owner.

In all the three exchanges examined above, gift exchange was the dominant form, while the idea of barter was only entertained as a way to launch or forestall an acquisition. The objects did have monetary value and the participants in these exchanges were keenly aware of that. But these calculations were never explicitly stated or even hinted at in the texts. Rhetorically, the sole concern was about the objects' symbolic value of transcendence and their spiritual affinity with their human owners. The literati economy is one which pretends to have no money.

Apparently, the anxiety regarding possession is best alleviated by the anxiety over its loss, which inspired ingenuous arguments to defend possession. Su Shi's improvisation, however, had a system. He acknowledged that the rocks are external to all these utilitarian, monetary, aesthetic or symbolic exploitations. Despite or precisely because of this, he was free to imagine them as empowered with agency and therefore coming to his possession not through transaction but, essentially, through mutual attraction. In this fashion, the objects maintained their externality, and the literatus legitimised his passion. They both kept their spontaneity, differently defined: the objects, in their absolute freedom beyond a human signification mechanism; the literatus, in his spontaneous subjugation to his heart's desires.

\section{Coda}

Coincidentally or not, the novel Dream of the Red Chamber begins with a 'superfluous rock' that was tempered by the Goddess Nüwa 女媧 to repair a hole in Heaven, but was left alone after the work was completed without it. Its desire for the worldly life turned it into Jia Baoyu 賈寶玉, or 'fake precious jade', a young sire who squandered his promises and would become a monk, 'useless' to society. When the readers sympathise with Baoyu and his like, they are underwriting Zhuangzi's original vision of planting the useless Tree-of-Heaven in a Land-of-Nothingness - archetype of the Illusory Land of Grand Void in the novel. From Zhuangzi to Su Shi until the Red Chamber, the useless underwent a long literary career. Its aesthetics contain an element of utopianism.

As Lyotard argues, there exist in everyone two contradictory forces: the human and the inhuman. If we are not born 'human', the 'inhuman' may well be 
a trace of childhood that persists into adulthood. Or, quite the contrary, it is the harmonisation of the heterogeneous, the education and institutionalisation that is inhuman. ${ }^{101}$ In whichever case, the enchantment of objects originates from a desire to go back in time, to erase the incessant, automatic signification built in by culture. Su Shi once wrote that his fascination with rocks began at an early age:

When Shi was twelve, I once played with other children to dig into a vacant ground in our house in the silk market. I found a strange rock, looking like a fish, its skin sleek and gleaming, and its colour pale green. Its whole body and surface sparkled with tiny silver stars. It clanged metallically upon knocking. When I tried to use it as an inkstone, it was good at producing ink, but had no hollow to store it in. My late father said, "It is a natural inkstone. It has the virtue of an inkstone, but is short in form". He bestowed it to me with the words, "It is a good omen for your literary work". I used it with endearment.

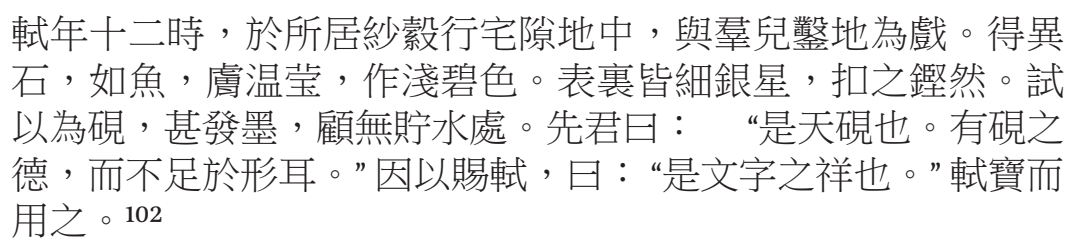

When the child Su Shi was enamoured by the unusual appearance of the rock and attempted to put it into use, Su Xun, his father, quickly derived a paradox between inner virtue and outer form, and further interpreted it as an auspice. The child's initial reaction to this stone was aesthetic surprise, which then turned into pragmatic calculation. Both kinds of reaction came without cultural mediacy. The father, however, represented the force of culture. He interpreted nature as mimics of the human and divined a supernatural order which worked nature to the favour of man. The perceptive child accepted his father's indoctrination and composed an inscription to elaborate upon the paradox that he was taught to discern. In the many inscriptions and poems on inkstones composed by the adult Su Shi, signification had become an internalised mode of response. But, even when the innocent reaction had been irrevocably overwritten by cultivated interpretation, Su Shi's persistent fascination with rocks still showed certain childish ecstasy. Perhaps his constant signification was only an afterthought to legitimise this pleasure.

\footnotetext{
101 Lyotard, The Inhuman, 3-4.

102 Su Shi, “Tianshiyan ming”, sswJ, 19.556.
} 
In Su Shi's long bureaucratic career, he repeatedly expressed nostalgia for his hometown below Mt Emei (symbolised by his one of miniature Qiuchi rocks). But he never returned - even when he had opportunities to do so. For him, 'home' was associated with childhood memories. It referred not so much to a real place, as to a spiritual state of innocence. In this sense, he was constantly home when he became a "man at odds" with this world, like a useless tree planted in the expansive wilderness. As he wrote in the year 1095, during his exile to Huizhou (then a semi-barbaric land):

$\begin{array}{ll}\text { 東坡信畸人 } & \text { Dongpo is indeed a man at odds; } \\ \text { 涉世真散材 } & \text { he comes into the world truly like a useless tree. } \\ \text { 仇池有歸路 } & \text { Here I find a way to return to Qiuchi - } \\ \text { 羅浮豈徒來 } & \text { it is not in vain that I have come so far to Luofu! } \\ \text { 踐蛇及如蛊 } & \text { Trampling on snakes, dining on insects - } \\ \text { 心空了無猜 } & \text { when my mind is empty, I take no dislike! } \\ \text { 攜手葛與陶 } & \text { Holding hands with Mr. Ge and Mr. Tao, } \\ \text { 歸哉復歸哉 } & \text { I shall return! I shall return!103 }\end{array}$

The term sancai 散材 is borrowed from the Zhuangzian story on Craftsman Shi's encounter with the sawtooth oak. Su Shi once played the role of the craftsman in the poetic dialogue with the strange rock. Now he identifies himself with the tree. Likewise, "a man at odds" appeared in the poem on the Dragon Tail Inkstone, used by the stone to describe him. Su has found the road to home after being convinced of (xin 信; zhen 真) his uselessness. As he humorously exclaims, the road of sorrow to Mt Luofu turns out to be a happy path to Qiuchi. The name Qiuchi has been turned into a composite symbol, referring to his miniature garden rocks, the legendary mountain, his hometown below Emei, his nostalgic memory of childhood, and a transcendental abode of permanence. As he took this rock with him to Huizhou and then Danzhou, it was a daily reminder of his road of return.

On this ever-returning road, Su Shi wanted to hold the hands of Tao Qian, a recluse, and Ge Hong, an alchemist. These two chosen companions, as discussed in the next two chapters, represent two aspects of the spontaneity $\mathrm{Su}$ Shi aspired to acquire: spiritual transcendence projected into a political persona, and physical transcendence pursued through esoteric arts. 


\section{Return to an Inner Utopia}

In what was to become a celebrated act in Chinese literary history, Su Shi began systematically composing "matching Tao" (he Tao 和陶) poems in the spring of 1095, during his period of exile in Huizhou. This project of 109 poems was completed when he was further exiled to Danzhou. It was issued in four fascicles, shortly after his return to the mainland in 1100. ${ }^{1}$ Inspired by and following the rhyming patterns of the poetry of Tao Qian, these poems contributed to the making (and remaking) of the images of both poets, as well as a return to simplicity in Chinese lyrical aesthetics. ${ }^{2}$

Thus far, scholarship has focused on the significance of Su Shi's agency in Tao Qian's canonisation. His image was transformed through Su's criticism and emulation: Tao came to be viewed as a spontaneous Man of the Way and not just an eccentric medieval recluse and hearty drinker. ${ }^{3}$ In other words, Tao Qian's 'spontaneity' was only created retrospectively in lament over its loss. The unattainability of the ideal is part and parcel of its worth.

In this chapter, I will further examine what Su Shi's practice meant for Su Shi himself. I argue that Su Shi's active transformation of and identification with Tao Qian's image were driven by the purpose of overcoming the tyranny of despair, deprivation and mortality. The apparent serenity of the "matching Tao" poems was therefore fundamentally paradoxical, a result of self-persuasion. As Ronald Egan has noted, Su deliberately sought to avoid sorrow and self-pity in exile, even though in his poems "one finds a degree of insistence upon contentment in the new surroundings that is unexampled in Tao's originals". 4 Such insistence betrayed the forced nature of their analogy, which was not lost on Su's contemporaries. As Su Che remarked in the preface to his

1 This anthology was highly popular in the Song and was repeatedly printed in various editions. The earliest existing wood-block print, preserved in the National Taiwan Library, was issued at the end of the Northern Song in Huangzhou; see Liu Shangrong 劉尚榮, Su Shi zhuzuo banben luncong 蘇軾著作版本論叢 (Chengdu: Bashu shushe, 1988), 24-33.

2 For further information on the rising aesthetic category of pingdan, related especially to Tao Qian's poetry, see Swartz, Reading Tao, 186-200.

3 For recent examples, see Tian, Tao Yuanming and Manuscript Culture, 4-6, 31-44, and passim; Swartz, Reading Tao, 87-90, 200-4, 210-11; Ashmore, Robert, The Transport of Reading: Text and Understanding in the World of Tao Qian (365-427) (Cambridge, Mass.: Harvard University Asia Center, 2010), 245-6.

4 Egan, Word, Image, and Deed, 234. 
elder brother's collected "matching Tao" poems, Tao abruptly resigned from office for a trivial slight, but Su Shi remained an official despite malicious defamation, prosecution and multiple exiles. ${ }^{5}$ The external 'traces' of their life trajectories were thus glaringly different. To justify his identification, Su defined his 'return' (gui 歸) as returning to an inner state of spontaneity, unconditioned by external contingencies. Tao's resignation was thus understood as a consequence of his natural disposition - just like Su's exile, an inevitable outcome of his unyielding character. In this regard, both not only 'returned' to living a spontaneous life in nature, but also chanced their return in seemingly different, but equally natural, fashion. Their difference was thus not a matter of choice (Tao) versus force (Su), but solely in that Tao's return was earlier, more resolute and more thorough. In this sense, Su should and could have emulated this paragon of disengagement to complete his own course of return.

Yet, another irony appears to have eluded Su Shi. When he sought to experience his exile through Tao's poetry, the wild southern landscape lost its immediacy and was instead fashioned after the poetic representation of Tao's orderly farmstead below Mt Lu (in modern Jiangxi Province). In other words, Su Shi metaphorically domesticated the Far South to be part of China's heartland. During the Northern Song, Huizhou (and especially Danzhou) signified the southern-most periphery of Chinese civilisation. Su's account of the local Dan 蛋 and Li 黎 people betrayed a strong Han-ethnocentric perspective. Solitude, cultural alienation and material deprivation often haunted the ageing poet. Matching Tao's farmstead poetry was therefore a means to distance and aestheticise his immediate surroundings, as well as transform them into a reflection of another, much different, literary landscape. In this sense, Su's return into nature was both his retreat from nature in its raw, undomesticated state, and his entry into a cultural landscape furnished with familiar ethical paradigms. Meanwhile, as an exile, he also discovered a pattern of disengagement in Tao's work which allowed him to voice political dissent. His sense of alienation from the immediate material nature, as well as from the distant political centre, together with his deepening interest in Daoist alchemy, contributed to his rediscovery of Peach Blossom Spring. It was no longer a secret corner isolated from the external world, as Tao Qian's original account had depicted, ${ }^{6}$ but an inner utopia with the features of an alchemist's grotto heaven. At last, as his rewriting of Tao's rhyme-prose "Return!" (Guiqulai xi ci 歸去來兮辭)

5 See Su Che, “Zizhan he Tao Yuanming shiji yin” 子瞻和陶淵明詩集引, Su Che ji, houji 21.111011 (also commonly known as “Dongpo xiansheng he Tao Yuanming shi yin” 東坡先生和陶淵 明詩引, as quoted in $s s s J, 35 \cdot 1882-3$.

6 See Tao Qian, “Taohuayuan ji bing shi” 桃花源記并詩, TYM, 6.479-80. 
shows, his journey of no-return into the ever-farther south was transformed into a journey of returning 'home' - that is, an inner realm of spontaneity.

\section{Literary Friendship with an Ancient}

As Robert Ashmore has noted, Tao Qian's reception is unique, comparable only to that of Qu Yuan 屈原 (c. 343-c. 277 BCE), in that his collection was "continuously augmented by successive generations of reader-authors who felt incited to commemorate the ancestor poet by composing new poems in the ancestor's voice". 7 This self-conscious emulation and identification formed a diachronic circle of literary friendship, the members of which not only shared a kindred 'ambition' (zhi 志), ${ }^{8}$ but literally spoke in one harmonised voice.

$\mathrm{Su}$ Shi was a poet with his own unique voice. His disposition towards erudite exposition, eloquent persuasion, hyperbole and the fantastical - often faulted by friends and foes as being either unrestrained ${ }^{9}$ or utterly 'crafty' and ornamented $^{10}$ - was quite unlike Tao Qian's poetry of understatement. Even in his "matching Tao" poems, Su Shi, in the words of the Qing commentator Ji Yun 紀昀 (1727-1805), "gathered his talents tight to approximate Tao, but from time to time revealed his true colours" 斂才就陶、亦時時自露本色. ${ }^{11}$ Often Su Shi's poems were found to be more clever, skilful and dramatic than Tao's originals. As the poet and critic Yuan Haowen remarked: "Though Dongpo matched the poetry of Tao, the aura and appearance [of his poems] are simply that of Dongpo." 東坡和陶、氣象祇是東坡. ${ }^{12}$ Despite their obvious difference, however, Su Shi's later poetry did change under the influence of Tao. It became more understated, at times deliberately so. As discussed in Chapter Two, for Su Shi the aesthetic appearance of 'the even and the plain' required the highest level of craftsmanship. To emulate Tao was to 'return to Tao', namely stylistic minimalism by an author capable of extreme sophistication.

$7 \quad$ Ashmore, Transport of Reading, 244.

8 As noted in Mencius, 5A.4, readers of the Odes should "deploy their minds to encounter the [ancient poet's] ambition" 以意逆志.

$9 \quad$ Huang Tingjian, for instance, cautioned his nephew not to learn from Su Shi's "being fond of abusing” (haoma 好罵); see “Da Hong Jufu shu”, 474.

As represented by Zhu Xi's repeated criticism; see, e.g., Zhuzi quanshu 朱子全書, ed. Zhu Jieren 朱傑人 (Shanghai: Shanghai guji chubanshe \& Hefei: Anhui jiaoyu chubanshe, 2002), vol. 18, yulei 語類, 139.4300, 4302, 4305-6, 4308, 4314. Quoted in the commentary to “He Tao 'Yinjiu ershishou” 和陶飲酒二十首, no. 20, sssJ, 35.1892.

12 Yuan Haowen, “Ba Dongpo 'Yinjiushi' hou” 咙東坡飲酒詩後, quoted in sssJ, 35.1891. 
Yet Su's emulation was not only driven by the literary value of Tao's poetry, but equally, if not more, by his admiration of and identification with Tao's poetic persona. He empathised with Tao's 'weakness', which was a "stubborn nature and unwieldy endowment, often in contradiction with worldly things" 性剛才拙與物多忤. ${ }^{13} \mathrm{He}$ argued that his remaining in office was but a 'guise' (ji 跡, literally 'trace' or 'footprint') and not true evidence with which to judge a character. ${ }^{14}$ Despite their different 'guises', Su intimated that he and Tao shared the same unyielding honesty which dictated their choices in life.

In the case of Su Shi, however, such 'choices' were hardly voluntary: his repeated periods of exile were the consequences of his failures to navigate the treacherous cycles of factional strife (between 'reformers' [xindang 新黨] and 'conservatives' [jiudang 舊黨]), which defined the Northern Song political landscape. Yet, by hinting at his "stubborn nature", Su Shi implied that his suffering was not just due to the forces of fate, but also - perhaps even more so due to his character. Assuming a certain responsibility for his suffering endowed him with power and agency. Only by claiming this power of choice did Su Shi's magic escape from exile into an inner utopia of freedom become possible. Adversity became opportunity. Material deprivation was understood as the precondition of his Daoist diet, therefore facilitating his pursuit of longevity. Likewise, social isolation helped him select friends from the large repertoire of ancient worthies. Tao Qian and Ge Hong, the latter reportedly became an immortal on Mt Luofu in Huizhou, were summoned to join a new triad of 'Three Gentlemen' (sanshi 三士). ${ }^{15}$ Holding their hands, he shall "Return! Oh return!” 歸哉復歸哉. ${ }^{16}$ The singular direction of returning home suggests teleology. He was not a victim of capricious fate but its master, able to maintain a stable and steady course of return through ups and downs, towards a primordial state of simplicity and spontaneity.

Despite this picture implying a predesigned direction, such a return in both lifestyle and literary expression could hardly be foreseen in Su Shi's previous writing. His first explicit attempt to emulate Tao Qian was in his "Eight Poems of the East Slope" (Dongpo bashou 東坡八首), written in 1081 during his exile

13 Su Che, "Zizhan he Tao Yuanming shiji yin", in Su Che ji, houji 21.1110-11.

14 This line, though found in Su Che's preface, was perhaps written by Su Shi himself. According to a Song author (who had a chance to see the manuscript of the preface at the home of Su Che's third son, Su Xun 蘇遜), Su Che's original preface claimed that Tao Qian was, in effect, a lesser talent, and that Su Shi's admiration showed his humility in appreciating every virtue in others. Su Shi revised this passage to its present, more reverent form. See Fei Gun 費衰, Liangxi manzhi 梁溪漫志 (Shanghai: Shanghai shudian, 1999), 4.1-2. See Su Shi, “He Tao ‘Du Shanhaijing”” 和陶讀山海經, no. 1, sssJ, 39.2130.

16 Ibid., no. 13, sssJ, 39.2136. 
in Huangzhou, to commemorate his farming experience. ${ }^{17}$ Eleven years later, Su Shi, now the Magistrate of Yangzhou 揚州, wrote twenty poems, each matching a piece in Tao Qian's poetic series entitled “Drinking” (Yinjiu 飲酒). ${ }^{18}$ He declared that he had developed a penchant for staying tipsy - or rather, constantly holding a half-empty wine cup while drinking sparingly due to his low tolerance of alcohol. This earliest instance of matching Tao's poems seemed to be a singular act, indicating no systematic agenda; were it not for Su's later exiles, it seemed unlikely to be resumed. According to Su Shi, in the third month of 1095, one day after an excursion to a waterfall in the mountains of Huizhou, he was inspired by his son's recital of Tao Qian's "Return to My Garden and Fields" (Gui yuantianju 歸園田居), and was determined to undertake a project of matching the entire catalogue of Tao's work. ${ }^{19}$ Only through this last systematic enterprise were his earlier sporadic emulations given a teleological perspective, portending a disposition that was yet to be fully developed. His last periods of exile were therefore also presented as necessary, both as a result of his natural disposition and as a precondition to complete his 'return'.

With these poems, Su Shi initiated a sub-genre in Chinese poetry called zhuihe 追和, or 'matching [an ancient poet's poems] in retrospect'. As he declared to Su Che:

Poets of earlier times had 'Imitating the Old' poems but had never matched the poems of an ancient author. Retrospectively matching the poetry of an ancient author begins with Dongpo!

\section{古之詩人有擬古之作矣, 未有追和古人者也。追和古人, 則始 於東坡! ${ }^{20}$}

To be precise, poets before Su Shi did occasionally write poems matching those of the ancients. ${ }^{21}$ Unlike Su Shi's, however, these were isolated random acts

17 Su Shi, "Dongpo bashou", sssJ, 21.1079-84.

18 See Su Shi, “He Tao 'Yinjiu ershishou' bing xu” 和陶飲酒二十首并敘, sssJ, 35.1881-92.

19 See Su Shi, “He Tao ‘Gui yuantianju liushou' bing yin” 和陶歸園田居六首并引, sssJ, 39.2103-4. Su Guo 蘇過 (1072-1123) was the only son who followed Su Shi to Huizhou and then Danzhou.

$20 \quad$ See Su Che, "Zizhan he Tao Yuanming shiji yin”, Su Che ji, houji 21.1110-11.

21 For instance, Li He 李賀, “Zhuihe Liu Yun” 追和柳惲, QTS, 390.4395, “Zhuihe He Xie “Tongque ji””追和何謝銅雀妓, QTS, 392.4412; Li Deyu 李德裕, “Zhuihe taishi Yan gong tong Qingyuan daoshi you Huqiusi” 追和太師顏公同清遠道士遊虎丘寺, QTS, 475.5392; Pi Rixiu 皮日休, “Zhuihe Huqiusi Qingyuan daoshi shi”追和虎丘寺清遠道士 詩, QTS, 609.7029, “Zhuihe Youdujun ciyun ershou” 追和幽獨君次韻二首, QTS, 609.7030; 
that never reached his scale or degree of systematic self-identification. Poetic exchange was first initiated in the Six Dynasties. ${ }^{22}$ It was a token of friendship, publically displayed, beckoning the whole republic of letters, as well as later readers, to bear witness. Since Bo Juyi and Yuan Zhen 元稹 (779-831), whose close friendship and extensive exchange of poetry made them known as YuanBo 元白 (also the name for their style), ${ }^{23}$ poetic exchange was used by poets to promote their similar styles, such as Ou-Mei 歐梅 (Ouyang Xiu and Mei Yaochen 梅堯臣 [1002-1060]) and Su-Huang 蘇黄 (Su Shi and Huang Tingjian). Poetic exchange was even deliberately exploited by otherwise obscure figures to form paired names or perceived literary groups, such as $\mathrm{Pi}-\mathrm{Lu}$ 皮陸 (Pi Rixiu 皮日休 [c. 834/839-after 902] and Lu Guimeng 陸龜蒙 [?-881]) and the 'Nine Monks' in Early Song. Su Shi's extensive matching of the poetry of Tao Qian, therefore, could be placed in this tradition as a deliberate effort to create a literary equal. Unlike in the other cases, which had real-life liaisons prior to literary exchanges, Su Shi essentially reversed the primacy and fashioned a literary friendship with Tao Qian through his one-way poetic exchange.

Moreover, exchange poetry was essentially social in nature and was often composed on occasions of genteel gatherings as a learned pastime. By the Northern Song, it was practised in every stratum of literary society. ${ }^{24}$ The percentage of 'matching poems' among one's compositions during a certain period, if faithfully preserved, served as a record and index of one's social activeness. Around one-third of Su Shi's extant poems were composed explicitly

Lu Guimeng 陸龜蒙, “Ci zhuihe Qingyuan daoshi shiyun bing xu” 次追和清遠道士詩 韻並序, QTS, 617.7114, “Ci Youdujun yun” 次幽獨君韻, QTS, 619.7128; etc. Such practices, however, were rare, whimsical and not influential. There are also a few 'matching Tao' poems attributed to Tang Yanqian 唐彥謙 (jinshi 861), now collected in QTS (671.7677). But scholars have pointed out that they were composed by the Yuan poet Dai Biaoyuan 戴表元 (1244-1310). See Wang Zhaopeng 王兆鵬, “Tang Yanqian sishishou yanshi zhengwei” 唐彥謙四十首貭詩證偽, Zhonghua wenshi luncong 中華文史論叢 (1993), 52: 226-44.

22 For a study on the transformation of forms of poetic exchange from the Six Dynasties through the Tang, see Zhao Yiwu 趙以武, Changhe shi yanjiu 唱和詩研究 (Lanzhou: Gansu wenhua chubanshe, 1997).

23 For the study on their exchange poetry, see Anna M. Shields, "Remembering When: the Uses of Nostalgia in the Poetry of Bai Juyi and Yuan Zhen”, Harvard Journal of Asiatic Studies 66.2 (2006): 321-61.

24 By focusing on the exchanges in the group around Ouyang and Mei, Colin S.C. Hawes even proposes that the main justification for writing poems during the Northern Song was "to develop and sustain human relationships through the regular exchange of poems with friends and acquaintances". See Hawes, The Social Circulation of Poetry in Mid-Northern Song (Albany: SUNY, 2005), 3. 
as matching poetry, with verbs like $h e$ 和 ('harmonise with'), chou 酬 ('reciprocate') or $d a$ 答 ('respond to') in the title. The percentage of exchange poems with his contemporaries was highest while he was in the capital, and lowest during his three periods of exile. There, the reading and matching of Tao Qian's poetry compensated for the lack of a literary society.

By methodically going through the entire corpus of Tao, Su Shi beckoned the camaraderie of an ancient kindred spirit, a gesture that served an ideological purpose. No one could or would match a contemporary poet's oeuvre in its entirety. In comparison, Su's matching of Tao's entire corpus elevated their relationship from that of friendship to, in Wendy Swartz's words, "virtual identification". ${ }^{25}$ While poetic exchanges with a contemporary could often be obligated by decorum within an immediate setting, matching an ancient author was a purely voluntary choice, one that broke free from the limits of time and space. Such a choice was thus invested with the significance of identifying a role model whose literary merit and moral stature were objects of emulation.

Su Shi's admiration played a crucial role in Tao Qian's canonisation; a process that began in the Tang and culminated in the Song. In her study on Tao's reception history, Xiaofei Tian discussed how Su Shi was dissatisfied with the word “gaze” (wang 望) in Tao's “Drinking, No. 5". He replaced it with “see" (jian 見), so as to dissolve the intentionality implied by "gaze" and render Tao's behaviour completely spontaneous. ${ }^{26}$ Similarly, Wendy Swartz observed how Su Shi, deliberately or not, misinterpreted Tao's poems to serve his argument that Tao had a genuine understanding of the Way (therefore differing in opinion from many Tang and Song critics). ${ }^{27}$ Thus, when Su Shi identified himself with 'Tao Qian', he was actually identifying with an icon of his own making. This was a figure whose unconventional behaviour was not driven by whimsical impulse, but rather sustained by a tenacious adherence to the ideal of spontaneity. At the end of this canonisation process, Tao emerged no longer as an eccentric hovering on the margins of literary history, but as a "moral hero" whose behaviour was consistently guided by the Way. ${ }^{28}$ By matching Tao's poems, Su Shi intimated that his own case was similar.

25 See Swartz, Reading Tao, 200-1.

26 Tian, Tao Yuanming and Manuscript Culture, 31-2.

27 Swartz, Reading Tao, 120-1.

28 For the "moral hero" and the Confucian ideal of reclusion, see Berkowitz, Patterns of Disengagement, 21. On Tao Qian's transformation into such a hero and the role Su Shi played, see Swartz, Reading Tao, 55, 73, 89-90. 


\section{A Metaphorical Landscape}

The semi-barbaric Far South posed physical and existential challenges to Su Shi. He needed to adapt to deprivation, as well as to an alien ethnic culture. This was especially the case in Hainan: an island divided from the mainland by a broad surging strait, with its still-rudimentary agriculture. As Kathleen Tomlonovic has observed:

In crossing the natural barrier of water, Su Shi had passed over a cultural barrier as well. Although the island was under the jurisdiction of the Song court, which had designed policies for subduing the inhabitants, the area, particularly the interior, remained the domain of the native peoples. ${ }^{29}$

Or as James Hargett pithily puts it, Hainan in the Northern Song was "the ultimate place of banishment". ${ }^{30}$ Living in the semi-barbaric inland of Hainan, Su Shi, one of the most learned men of the empire, was an oddity. To cope with his deep feeling of dislocation, Su Shi had to assimilate the foreign into his own system of meaning. He did this by poetically transforming the wilds that surrounded him, conforming them to the map of Tao Qian's cultivated 'garden and fields'. The culturally distinctive natives were assorted into various archetypes familiar in a poetic countryside. Yet, Su Shi's own assumed roles were fluid and varied with the context. At times he represented himself as being completely integrated into this wild landscape; at other times, however, he adamantly adhered to his political and cultural identity, and played the role of a civilising force.

Modern academic literature often celebrates Su's later exile poetry as evidence of his genuine love of nature and of 'the folk'. Even though James Hargett remarked that the general praise of Su Shi's propensity to "turn disaster into optimism" was too simplistic and ignored the phases of Su Shi coping with adversity, he nevertheless took Su's optimism, his 'friendship' with the common Hainan locals, and his 'identification' with Tao Qian literally. ${ }^{31}$ As I will argue in this (and, in another way, also in the next) chapter, despite Su's repeated invocation of 'return', doubts remain about how thorough or 'natural' his 'return' into the southern landscape was. About half of his poetry in Hui-

29 Kathleen M. Tomlonovic, "Poetry of Exile and Return: A Study of Su Shi" (PhD diss., University of Washington, 1989), 169 .

30 James M. Hargett, "Clearing the Apertures and Getting in Tune: The Hainan Exile of Su Shi (1037-1101)", Journal of Song-Yuan Studies (2000), 30: 144.

$31 \quad$ Ibid., $163-4$. 
zhou and Danzhou was written to match Tao's. This fact poses the uneasy question of how much Su Shi allowed his immediate experience of nature to flow into words, if, to him, the entire landscape was an echo of Tao Qian's poetry.

Indeed, it is questionable as to whether any 'garden and fields' poetry can faithfully represent the unmediated countryside, given the fact that such poetry must employ literary skills, exist in a cultural system of reference, and acquire its significance through presenting an alternative space to the urban centre. Tao Qian's countryside was already populated by conventions and archetypes that were formed in the eremitic tradition before him. In comparison, Su Shi's countryside is even more metaphorical and idealised, at times so utopic that its rural residents are all moral ideals incarnate. This feature is explicit in Su's first "matching Tao" poem written in Huizhou, in response to Tao's "Returning to My Garden and Fields". ${ }^{32}$ The opening verse in Tao's series celebrates his return after thirty (or thirteen) years of service. ${ }^{33}$ Of the ten couplets, eight use strict parallelism, imposing order onto the actual landscape

32 Tao's original consists of five poems, but Su Shi's matching series has six. The collection of Tao in Su's possession must have mistakenly included a sixth poem that was an imitation poem by Jiang Yan 江淹 (444-505), titled “Tao Zhengjun tianju” 陶徵君田居, in a series of thirty “Zatishi” 雜體詩; see Hu Zhiji 胡之焂, Jiang Wentong ji huizhu 江文通集㝙註 (Beijing: Zhonghua shuju, 1984), 4.156-7. This imitation poem was not infrequently included in early editions of Tao's poetry.

Whether Tao's original fourth line was "Away I had been from home for thirty years" (yiqu sanshi nian一去三十年) or “thirteen years” (shisan nian 十三年) is not just a question of textual variants, it is also associated with the broader picture of Tao's chronology, biography and the traditionally quintessential question on whether he was so loyal to the Jin Dynasty that he refused to serve under the Song (and even purportedly refused to use its reign names). Tao Qian's bureaucratic career had many obscurities. Yuan Xingpei's latest study supports the argument that he did serve under the Song. According to Yuan, Tao Qian held some short bureaucratic posts in his twenties. He lived idly until joining the military government of Huan Xuan 桓玄 (369-404) in 398, aiding the latter's rebellion against the Jin Dynasty. He stayed in service until the winter of 401, when his mother died and he returned home for the three-year ritual mourning period. Huan Xuan was defeated and killed by Liu Yu 劉裕 (363-422; r. 420-22), the would-be founder of the Liu Song Dynasty (420-479). Tao Qian then joined Liu Yu's military government in 404, became the Magistrate of Pengze County in 405, and resigned after some eighty days. See Yuan Xingpei, “Tao Qian nianpu jianbian” 陶淵明年譜簡編, TYM, 849-58. Clearly, if this poem commemorates his returning home after roughly three decades of desultory civil service, it should have been written after his final return in 405 . "Thirteen" is likely a variant created to obliterate Tao's service under Liu Yu, which would have enraged some later readers as it was a betrayal of his former patron. 
and creating a sense of regularity associated with farmstead life. In Su Shi's matching poem, strict parallelism is similarly used in the first four couplets:

$\begin{array}{ll}\text { 環州多白水 } & \text { Surrounding this prefecture, many white waters; } \\ \text { 際海皆蒼山 } & \text { hemming the coast, all dark hills. } \\ \text { 以彼無盡景 } & \text { By virtue of this infinite landscape, } \\ \text { 寓我有限年 } & \text { let me lodge here for my finite years! } \\ \text { 東家著孔丘 } & \text { The neighbour to the east houses Kong Qiu; } \\ \text { 西家著顏淵 } & \text { the neighbour to the west houses Yan Yuan! } \\ \text { 市為不二價 } & \text { The merchants always set an honest price; } \\ \text { 農為不爭田 } & \text { the farmers never fight over their fields. }{ }^{34}\end{array}$

The "infinite landscape", of rapid waters and dark mountains, suggests a sublime nature of black and white - the 'colours' in a literati landscape painting. Using Tao's closing-in perspective and orderly depiction, Su turns the wilderness into a protective force, benignly "surrounding" and "hemming in" the human domain where the poet could reside. In this small utopian society, not only are the residents in Su's elite neighbourhood Confucian sages, but even the merchants and farmers are paragons of decency. In this idyllic vision, Huizhou appears to be no longer a wild place on the periphery of Chinese civilisation, but a privileged heartland that represents natural order, civil harmony and moral perfection.

Su Shi's matching poems often downplay the elements of fear and anxiety in Tao Qian's originals, further creating a sense of smooth reconciliation with nature. The following couplet by Tao betrays a tangible fear of idling away a life in insignificance, symbolised by natural forces preying on his harvest:

常恐霜霟至
零落同草莽
$\begin{gathered}\text { lest my crops fall prey, like grasses grown in the } \\ \text { wilderness. }\end{gathered}{ }^{35}$

In Su Shi's matching couplet, nature itself imposes the principle of order and is the real author of regulated and cultivated poetic lines:

春江有佳句 The spring river contains marvellous lines of poetry; 我醉墮渺莽 in my drunkenness they fall into the vast nebulosity. ${ }^{36}$

\footnotetext{
34 Su Shi, “He Tao “Gui yuantianju’ liushou” 和陶歸園田居六首, no. 1, sssJ, 39.2104.

35 Tao Qian, "Gui yuantianju", no. 2, TYM, 2.83.

36 Su Shi, "He Tao 'Gui yuantianju”, no. 2, sssJ, 39.2104-5.
} 
The poet declares nature to be a fellow author; all he needs to do is record the wonderful lines that the river has imparted to him. Ironically, he apologises for being too drunk to be that faithful scribe, although he is still able to commemorate his oblivion. Rhetorically, drunkenness loosens the grip of consciousness and brings the poet closer to a state of spontaneity. It appears that the poet, in the soft dissolution of consciousness, feels at one with the flowing river, itself a symbol of spontaneous creation. But, if nature does not write poetry after all, it is then the silent poetry of spontaneity that finally eludes the sober poet. Whatever comes to his brush is already a cultivated language, mediated moreover by cultural memory and paradigms of the past. Even here, "vast nebulosity" (miaomang 渺莽) might not have occurred naturally to Su Shi; he may have said so only to match Tao Qian's rhyme mang 莽. The mang in Tao's line represents the vegetation to be consumed by the merciless seasonal forces; while, for $\mathrm{Su}$, it is the oceanic unconsciousness that he willingly falls into. Nature is no longer ruthless and insentient, but benign and protective of the human cause. Su Shi's frequent rhetorical technique of personification implies a pervasive homocentric perspective, a reassertion of the self as the centre of the observation.

\section{A Poetic Ethnography}

As Su reconstructs the landscape, he also develops a way of reenvisioning the local native's ethnicity. To begin with, the Chinese writing system itself encoded a certain Han ethnocentrism. Huizhou aboriginals were addressed as Dan 蛋. As a variant of yan 蜒 ('slug'), this etymologically derogative term referred to an ethnic group who lived in boats on the water. The natives of Hainan were called Li 黎, the namesake of a local mountain: Limu, or 'Mother of Li' 黎母山. $L i$ literally means 'black' - a reference to their dark skin caused by the equatorial climate. Since for the Han, dark skin suggested daily toil in the fields, its association implied social, economic and political subjugation. This association had been established and strengthened by these ancient terms for the underclass: limin 黎民 ('dark skinned folks') or qianshou 黔首 ('heads wrapped in black handkerchiefs') - the old Qin Dynasty term for the common people. Such ethnic designations evoked the exotic and the alien, as well as the Han's ethnic superiority.

Su Shi's colourful report on local customs might have selectively magnified the exotica. According to these reports, in Huizhou he sometimes stepped on snakes and dined on insects. ${ }^{37}$ In Danzhou, the Li people planted little rice 
and dined instead on taro roots and, sometimes, smoked mice and bats. ${ }^{38}$ They wore coconut hats ${ }^{39}$ and clothes made from cotton tree fibre; ${ }^{40}$ and they killed oxen in shamanic sacrifices to cure diseases, instead of using them to plough the fields. ${ }^{41}$ In his letters to friends across the straits, Su once bitterly wrote, "I and my son are doing fine; but mixing with the Li and the Dan, we barely feel our humanity” 某與兒子粗無病, 但黎、蜒雜居, 無復人理. ${ }^{42}$ Here, the definition of 'human' is constructed ethnically. As Robert Campany points out, eating grain and cooking are presented in the Book of Rites as being

among the traits possessed by human beings par excellence. Anything less - even if it is the result of natural, local variations - counts as less than fully human and needs to be modified. ${ }^{43}$

Su Shi, among the southern natives, appeared to feel the eventual dissolution of his own ethnic identity, or even his humanity (renli 人理).

However, these traces of despair that were articulated in private epistles were rarely found in his poetry, where, more often than not, he celebrated rustic society. He again aspired to model himself after Tao Qian, who, in his poetry, cordially drinks with his farmer neighbours ${ }^{44}$ or casually chats with them in passing on a village road. ${ }^{45}$ To emulate this spirit, $\mathrm{Su}$ Shi wrote the following couplets:

I.

江鷗漸馴集 硰䝿已還往
River gulls get familiar and gather around me; an old man of Dan has become my company. ${ }^{46}$

38 Su Shi, “He Tao 'Quannong' liushou” 和陶勸農六首, sssJ, 41.2254-57; “Wen Ziyou shou” 聞子由瘦, $s s s J, 41.2257-58$.

39 Su Shi, “He Tao 'Quannong' liushou”; “Yeziguan” 椰子冠, sssJ, 41.2268-9.

$40 \mathrm{Su}$ Shi, “He Tao 'Nigu jiushou”” 和陶擬古九首, no. 9, sssJ, 41.2266.

41 Su Shi, “Shu Liu Zihou 'Niufu' hou” 書柳子厚牛賦後, sswJ, 66.2058.

42 Su Shi, “Yu Cheng Quanfu shiershou” 與程全父十二首, no. 9, sswJ, 55.1626.

43 Robert Ford Campany, "The Meaning of Cuisine of Transcendence in Late Classical and Early Medieval China", T'oung-Pao (2005) 91.1/3: 8-9.

44 See, e.g., Tao Qian, "Yinjiu" no. 9 and no. 14, TYM, 3.256, 268; “Lianyu duyin” 連雨獨飲, TYM, 2.125 (where the neighbour sent some wine); "Guimaosui shichun huaigu tianshe ershou” 癸印歲始春懷古田舍二首, no. 2, TYM, 3.203 (where he sent some wine to a new neighbour).

46 Su Shi, “He Tao ‘Gui yuantianju”, no. 2, sssJ, 39.2103. 
II.

一與䖪鼠醉 蒼顏兩摧䅡

III.

鳺舌倘可學 化為黎母民
Getting drunk with an old man of Dan two greying faces glow in utter waste. ${ }^{47}$

Were it possible to acquire their butcherbird tongue, I shall transform to a native below Mt Mother of $\mathrm{Li}^{48}$

In couplet I, Su Shi refers to a story in Liezi 列子, where river gulls would gather around a guileless fisherman, until one day he was persuaded by his father to catch the gulls. However, the gulls discerned his treacherous intentions and refused to fly down. ${ }^{49}$ In this couplet, Su Shi wants to reassure his reader that he has forgotten all chicanery, so that river gulls and even an "old man of Dan" keep his company. This parallelism suggests a perspective from which the local Dan natives are viewed on a par with natural creatures. The viewer places himself in a position of active agency, observing and commentating on the passive local subjects. The "old man of Dan" does not speak; like the river gulls, he is a stage prop to witness the author's claimed dissolution of his cultural and social superiority.

Couplet II celebrates the unassuming way in which he goes on a drinking spree with an "old man of Dan". We do not know whether this is the same old man mentioned in couplet I, or another (or indeed a fictitious one). As in couplet I, this good friend of Su's is identified only by his gender, age and ethnicity. These generic features make him less of an individual and more of a stereotype. In contrast, in Tao Qian's scenes of drinking parties, though his neighbours are also unidentified, they are often endowed with agency, capable of initiating events or giving speeches. Such realistic details make Tao's rustic company more convincingly individualistic, if not necessarily less fictive.

In couplet III, the author jovially shows the alacrity with which he wishes to become a native of $\mathrm{Li}$ - if only he was able to acquire their "butcherbird tongue"! In Hainan, Su Shi apparently suffered from linguistic alienation. He did not understand the native Hainan dialect but was able to tutor some local students, who perhaps could speak in a modified and standardised version of the dialect. Su Shi, after decades of his itinerant bureaucratic career across eastern, central and northern China, must have understood, if not spoken,

\footnotetext{
47 Su Shi, “He Tao 'Xiasun tianshe huo” 和陶下潠田舍獲, sssJ, 42.2316.

48 Su Shi, “He Tao “Tianshe shichun huaigu ershou” 和陶田舍始春懷古二首, no. 2, sssJ, 41.2281 .

49 See Yang Bojun 楊伯峻, Liezi jishi 列子集釋 (Beijing: Zhonghua shuju, 1979), 2.67-8.
} 
more than one dialect. Yet nowhere else during his provincial tenures did he comment in writing upon the local accent. ${ }^{50}$ In Hainan alone, not only did the native people appear as innocent natural creatures, but their language also resembled bird chirps, deprived of meaning to the 'cultured' ear. The political, economic and cultural dominance of the Han Chinese was simultaneously understood as an anthropological advantage. Su Shi's incapacity to learn the local dialect was regarded as physiological - since his tongue, literally, was that of a human and not of a butcherbird.

These zoogeographical metaphors - assigning images of animals to represent ethnic groups of different regions - were certainly applied only to local natives, alien to Han culture and unable to read such verses. Nevertheless, these poems would have been read by local elite, including officials, students and other members of the gentry, as well as by members of Buddhist or Daoist clerical orders. Su Shi clearly did not mean to insult his local friends and hosts; he used such metaphors because they were integrated into the established cultural hierarchy. Presumably his local hosts were sympathetic, or at least accustomed, to the viewpoint of Han cultural dominance.

Equally notable is the difference between genres: when Su Shi's prose laments his dislocation, his poetry romanticises his relocation. This discrepancy betrays an element of deliberate persuasion in Su Shi's vow of assimilation. Furthermore, to blend his own outlandish figure into a cast of local characters, Su Shi's other approach is to dress them in outfits of cultural archetypes. As a result, if at first the alien people of the south strike Su Shi as being virtually part of nature, on second thoughts he suspects their hidden intelligence or humanity, with their apparent innocence resembling the disguises of recluses or earthly immortals.

This second approach also partly derives from Tao Qian's poetry. For instance, in Tao Qian's ninth poem in "Imitation of the Old", he depicts a 'scholar of the East' who lives in deprivation (eating only nine times in thirty days and changing his hat once in ten years), but exhibits divine physical and spiritual wellbeing. Evidently, this is a Daoist figure nourished not by normal food but by cosmic energy ( $q i$ 氣). Tao Qian expresses a desire to follow him "from now on to the time of cold". ${ }^{51}$ The "time of cold" (suihan 歲寒) refers to a cosmic winter when man must rely on his own inner source of warmth to fight against

5o Su Shi seemed to be well-versed in dialects. There is an anecdote which tells that he deduced that a figure in Li Gonglin's painting was from Fujian, just from the unique shape of the person's mouth in pronouncing "six". See $S S N P, 30.977$.

$5^{1}$ See Tao Qian, “Nigu jiushou” 擬古九首, no. 5 , TYM, 4.327. In the edition used by Su Shi, it is the ninth poem. 
forces of mortality like age, disease and death. This poem could be read either as Daoist or as a moral allegory.

Su Shi matched this poem twice. In the first instance, he transforms this 'scholar of the East' into a woodcutter of Li ethnicity:

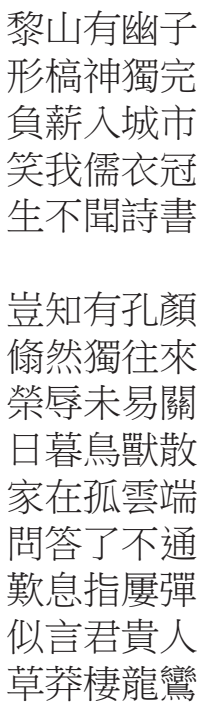

遺我古貝布 海風今歲寒
There is a secluded mister in the Mountain of $\mathrm{Li}$, his form wizened, his spirit alone remains intact. Bearing a load of firewood to the market in town, he laughs at my scholar's robe and hat.

In his life he has never heard of the Odes or the Documents, not to mention knowing Confucius or Master Yan. In utter freedom, he comes and goes all alone; glory or disgrace hardly crosses his mind. At sunset, birds and beasts retreat to their hidings; he heads to a home atop the lonely clouds. I barely understand his questions or replies; I sigh and flick my fingers in despair. He appears to say, "You, sir, are of noble standing; like a dragon or a simurgh, you come to nestle among the weeds".

He presents me a bolt of cotton tree cloth the sea wind of this season is cold. ${ }^{52}$

This "secluded mister" enriches the repertoire of proverbial woodcutters in recluse literature. Like Tao Qian's scholar who is nourished by immaterial energy, his intact spirit defies the decline of his form. He is a son of nature, never blighted by education. He laughs at Su Shi's scholarly attire, just as in the Analects when the world-traveller Confucius was jeered at by recluses who preferred to keep their virtue private. ${ }^{53}$ The woodcutter's ignorance of Confucian sages was proof that his virtue developed naturally, instead of being cultivated according to moral commands. Like a Daoist figure, he roams in freedom and cares little about worldly affairs. Su could barely understand him, a speaker of the "butcherbird tongue". Yet, the woodcutter recognises Su Shi as a man of standing, now in misfortune. He may not be aware of Su's spectacular talents or the political theatre in the distant world across the straits, yet he appears to have grasped Su Shi's condition intuitively. He presents a token of empathy - a

$5^{2} \quad$ Su Shi, “He Tao 'Nigu jiushou”, no. 9, sssJ, 41.2266.

53 See Analects 18.5-8. 
bolt of plain, warm, homespun cloth. The portrayal of this woodcutter combines elements from various poetic stereotypes: a recluse who reveals his identity on encountering a traveller, an earthly immortal, and an enigmatic zhiyin 知音 - a kindred spirit who understands one's wordless music.

Su Shi's self-image in this poem is constructed through the eyes of a common man. His moral stature, demeaned in the capital, is recognised by someone whose genuine nature is not distorted by the establishment. By depicting the periphery as morally superior to the centre, Su Shi sends to his readers, especially those at the central court, a political complaint.

The woodcutter of Mt Li provides an image of a man whose desirability derives from what he is not - that is, not exposed to learning, not caring about worldly power or glory and not enmeshed in the network of meaning. Su Shi cannot become a native of Mt Li because his 'natural state' was irrevocably lost in the past. Even in his 'return', Tao Qian style, the acquired traces of culture are so deeply inscribed onto him that they become the very essence of his identity. Thus, his poetry betrays a perpetual struggle between deliberate abandonment and adherence to his political and cultural self. Another poet whom Su Shi frequently read in Huizhou and Danzhou was Liu Zongyuan 柳宗元 (773-819). According to Lu You 陸遊 (1125-1210), Su once called Tao and Liu his "two friends in my banishment to the south". ${ }^{44}$ When Liu Zongyuan was banished to Yongzhou 永州 (in modern Hunan Province), he turned himself into a cultural force committed to the noble cause of 'transforming the barbarians' ${ }^{55} \mathrm{Su}$ Shi explicitly opposed this approach and once declared:

$\begin{array}{cl}\text { 莫學柳儀曹 } & \begin{array}{l}\text { I should not be like Mr. Liu, Vice Director of the } \\ \text { Ministry of Rites, }\end{array} \\ \text { 詩書教记獠 } & \text { preaching the Odes and the Documents to the savages. }{ }^{56}\end{array}$

Yet, despite all his claims of losing a sense of rank and cultural identity, some revealing cases show that Su Shi defended his identity all the more against the threat of alien surroundings.

Su Shi was not officially obligated to 'transform the barbarians'. Under the Tang and the Song, exiled officials often assumed various local administrative

54 See Lu You 陸遊, Laoxue'an biji 老學庵筆記 (Beijing: Zhonghua shuju, 1979), 9.120.

55 See, e.g., Liu Zongyuan, “Tong Liu Ershiba yuanzhang shujiu yanhuai ganshi shushi” 同劉 二十八院長述舊言懷感時書事, in Liu Hedong ji 柳河東集 (Shanghai: Shanghai renmin chubanshe, 1974), 42.674-9.

56 See Su Shi, “Jiang guo Guangzhou yong Guo yun ji Mai Dai erzi” 將過廣州用過韻寄邁 迨二子, $s s s J, 44.2390$. 
and educational duties. Han Yu and Liu Zongyuan were magistrates in charge of prefectural affairs, and Su Che was a tax clerk in Yunzhou 筠州 (now Gao'an 高安, Jiangxi Province). Su Shi, however, was typically discharged of all duties in his exiles, probably because of the malice felt towards him. ${ }^{57}$ Even so, Su could not help feeling an obligation to public affairs. ${ }^{58}$ In Huizhou, he dispensed medicine, built a bridge and advised on the construction of the aqueduct system in Guangzhou. Half a year after coming to Danzhou, he composed a series of poems matching Tao's “Exhorting Farmers” (Quannong 勸農) in the classical tetrasyllabic metre, for the apparent purpose of promoting agriculture and sericulture among the (probably illiterate) natives. ${ }^{59}$ In Tao Qian's time, 'exhorting farmers' was a county official's duty. ${ }^{60}$ Tao possibly composed these poems in his capacity as libationer (jijiu 祭酒), a minor educational office in the prefecture. ${ }^{61}$ As a man out of office, however, Su's "Exhorting Farmers" poems projected him as an overseer of the farmers, therefore falsifying his repeated claim of becoming one of them.

This constant change of positions between the dissolution and the reaffirmation of his identity is a staple of Su Shi's late poetry, and such a paradoxical image might have been deliberate. Unlike Tao Qian, Su Shi enjoyed a huge and zealous contemporary audience. Tao, obscure in his time, explicitly recommended his words to the "later-born". 62 This gesture of writing for future readers recalls similar remarks from Confucius, Sima Qian and Yang Xiong, cultural heroes who suffered from being misunderstood by their contemporaries, and so entrusted their memory to future generations. In contrast, though Su Shi must have like-mindedly written for the "later-born", he was keenly aware of his popularity. According to Zhu Bian 朱弁 (1085-1144), even in Su Shi's youth, the things he wrote were immediately copied and broadly recited. ${ }^{63}$ Scholars have argued that after the Crow Terrace prosecution, Su Shi became wary of the dissemination of his works, and this wariness left its impact on his literary compositions. ${ }^{64}$ According to rumour, Su was banished to Hainan after Chancellor Zhang Dun 章㧝 $\left(1035^{-1105}\right)$ read a poem that celebrated his easy life in

\footnotetext{
57 As noted in Tomlonovic, Poetry of Exile, 192-3.

$5^{8}$ On Su Shi's engagement with social problems in a private capacity, see Egan, Word, Image, and Deed, $127-33$.

59 Su Shi, "He Tao 'Quannong' liushou", sssJ, 41.2254-57.

6o See “Zhiguanzhi” 職官志 in Jinshu, 24.746.

61 See Yuan Xingpei's note to this poem, TYM, 1.35-6.

62 Tao Qian, “You hui er zuo yishou bing xu” 有會而作一首并序, TYM, 3.306.

63 See Wu Wenzhi, Song shihua, vol. 3, 2950.

64 See Uchiyama Seiya 內山精也. “Tōba Utai Shi'an ryūten kō”「東坡烏台詩案」流伝 考, Yokohama Shiritsu Daigaku ronsō 横浜市立大学論叢 (1996), 47·3: 111-48.
} 
Huizhou. ${ }^{65}$ Even before his exile ended, his Hainan poetry was already circulating in the mainland. Directly after his death, when the government placed a ban on his writing, his 'overseas poetry' still enjoyed such popularity that whoever could not recite these poems was at a disadvantage in conversation. ${ }^{66}$ Bearing his contemporary readership in mind, Su Shi must have cautiously controlled his poetic persona. Thus, although on the one hand he gaily reported every step of his 'return into nature', on the other he reassured his reader that he never forgot the good Confucian's responsibility to domesticate the barbaric natives. These two sides combined to create a powerful, albeit paradoxical, political persona who loftily transcended worldly affairs, while dutifully observing moral commands - the very moral paradox that ennobled ancient paragons of reclusion. ${ }^{67}$

By any account, Su Shi remained a cultural force. Soon after he arrived in Hainan, a friend sent him more than a thousand fascicles of books across the sea. ${ }^{68}$ Su might have generously used these books to tutor local students, who kept him constant company. ${ }^{69}$ In turn, he sometimes advised them in matters of writing and calligraphy. ${ }^{70} \mathrm{~A}$ certain Jiang Tangzuo 姜唐佐 (jinshi 1103) was especially gifted. ${ }^{71}$ Since no candidate from Hainan had ever succeeded in the metropolitan exam, Su Shi encouraged Jiang to "break Heaven's desertion" ( $p o$ tianhuang 破天荒). Two years after Su Shi's death, Jiang finally succeeded. ${ }^{72}$ Even though Su Shi never made an explicit commitment to 'transforming the barbarians', his contemporaries, nevertheless, were keen to point out his fore-

65 This anecdote was first recorded by Zeng Jili 曾季㨋 (twelfth century); see Tingzhai shihua 艇齋詩話 (Hong Kong: Guangwen shuju, 1971), 66-7. The concrete plot was not necessarily accurate, but Zhang Dun's desire to see Su Shi dead perhaps was. More on this story, see ch. 5, 193 .

66 See Wu Wenzhi, Song shihua, vol. 3, 2950.

67 See Vervoorn, Men of the Cliffs, 28-40, 229; Berkowitz, Patterns of Disengagement, 20-35.

68 See Su Shi, “He Tao “Zeng Yang zhangshi”” 和陶贈羊長史, sssJ, 41.2281-2.

69 See e.g., Su Shi, "Beijiu duxing, bianzhi Ziyun, Wei, Hui, Xianjue sili zhi she, sanshou” 被 酒獨行遍至子雲威徽先覺四黎之舍三首, sssJ, 42.2322-3; "Yong Guo yun, Dongzhi yu zhusheng yinjiu” 用過韻冬至與諸生飲酒, $s s s J, 42.2324-5$; “Zeng Li Si Yanwei xiucai” 贈 李皆彥威秀才, sssJ, 43.2352-3; etc.

70 See Fei Gun, Liangxi manzhi, 4.2.

$71 \quad$ For Su Shi's correspondence with Jiang, see Su Shi, “Yu Jiang Tangzuo xiucai liushou” 與姜 唐佐秀才六首, $s s w J, 57 \cdot 1739-40$.

72 This story is authenticated by Su Che; see Su Che, "Bu Zizhan 'Zeng Jiang Tangzuo xiucai' bing yin” 補子瞻贈姜唐佐秀才並引, Su Che ji, houji, 3.909. 
sight and beneficial cultural influence ${ }^{73}$ - an influence that, ironically, belied his claim of assimilation into the native folk.

\section{The Poetry of Discontent}

In a number of poems written during this last period of exile, Su Shi meditated upon the value of the individual and concluded that it should not be sacrificed for a vague 'public good' or absolute loyalty to the sovereign ruler. For Chinese literati, the dilemma between public service and disengagement was perpetual. Tao declared, of all literati:

或擊壤以自歡 Some delight themselves in the game of 'hitting the wood-stick';

或大濟於蒼生 some bring great benefit to the whole humble populace. ${ }^{74}$

Rang 壤 is a shoe-shaped stick made of wood. In the game, one first plants a stick some distance ahead and then throws another to hit it. A story tells that an octogenarian, living in Emperor Yao's reign, was playing this game by the roadside. When an onlooker praised the virtue of the Emperor who ensured his happiness, the old man retorted:

I rise when the sun rises; I rest when the sun sets. I dig a well to drink and plough the fields to eat. What does the power of the Emperor have to do with me?

\section{日出而作, 日入而息。丵井而饮, 耕田而食。帝力于我何有 哉? 75}

The original moral lesson is the Daoist ideal of governance without interference. Tao Qian, however, used this reference to illustrate an example of private virtue which delights only its possessor. Yet Tao's poetry does sometimes

\footnotetext{
73 This story is also related in Shao Bo 邵博, Shaoshi wenjian houlu 邵氏聞見後錄 (Beijing: Zhonghua shuju, 1983), 17.133-4.

74 Tao Qian, “Gan shibuyu fu” 感士不遇賦, TYM, 5.431-3.

75 See Huangfu Mi 皇甫䍀, Gaoshi zhuan 高士傳 (Congshu jicheng edition. Shanghai: Shangwu yinshuguan, 1937), 1.6.
} 
betray an anxiety over leading a life wasted and unfulfilled. ${ }^{76}$ So, despite his awareness that to "bring great benefit to the whole humble populace" was noble and laudable, what accounted for Tao's resignation? Was it simply because of those quotidian scribbles and squabbles in a lowly bureaucrat's humdrum life? Did he just prefer the rural quietude? The war-ridden interregnum of Tao's times had spurred speculation, ever since the Late Tang, that his resignation had been of a grander nature, such as a protest against the moral and ritual disorder of the age. According to this version, Tao's choice was totally consistent with the Confucian attitude of seeking employment with dedication, until all measures are tried and failed in an age of darkness. ${ }^{77}$ As Aat Vervoorn describes it:

The gentleman serves in office as long as by doing so, he can further the Way; once that becomes impossible he must resign to avoid moral compromise. ${ }^{78}$

This orthodox reading was inconvenient for Su Shi's identification with Tao. Unlike Tao Qian, Su was a prominent political figure and had to carefully avoid criticising the current regime. A hint of frustration would be noted as lèse majesté, inappropriate at the least and deadly at the most. Perhaps in regard to the potential censorship, Su Shi contended that Tao Qian (and he himself) were simply endowed with a "partial nature", ill-fitted to the world. Both Tao's and his return were but a natural result of their disposition:

媄我與先生 所賦良奇偏 人間少宜適 惟有歸耘田
Alas, you and me, sir both are endowed with an extremely partial nature. Nothing, if any, befits or pleases us in the realm of man; returning and ploughing the fields is all we can muster. $^{79}$

To support this image of Tao, Su Shi highlights a fact in Tao Qian's résumé: his initial acceptance of official appointment. Unlike the usual opinion that sees Tao's bureaucratic career only as a necessary condition for his resignation, $\mathrm{Su}$ argues that Tao's taking office and his resignation were both motivated by his

76 On Tao Qian's sense of social mission, see Kwong, "Naturalness and Authenticity", 37-40.

77 See Swartz, Reading Tao, 55-73, passim.

78 Vervoorn, Men of the Cliffs, 30.

79 Su Shi, “He Tao 'Yuanshi shi Pang Deng”” 和陶怨詩示龐鄧, sssJ, 41.2271. 
authentic self, dictated by concrete circumstances and not by any grand moral agenda.

\begin{tabular}{|c|c|}
\hline 淵明初亦仕 & $\begin{array}{l}\text { Yuanming initially also entered officialdom; } \\
\text { it was sincere of him to say that ritual music was his } \\
\text { livelihood. }\end{array}$ \\
\hline $\begin{array}{l}\text { 不樂乃徑歸 } \\
\text { 視世羞獨賢 }\end{array}$ & $\begin{array}{l}\text { Taking no delight in it, he simply returned; } \\
\text { looking at the world, he was ashamed to be virtuous } \\
\text { alone. }{ }^{80}\end{array}$ \\
\hline
\end{tabular}

Xiange 弦歌, or 'string music and singing', refers to a story in the Analects. Confucius' disciple, Ziyou 子游, was once the Magistrate of Wucheng 武城 (in modern Shandong Province). Despite the insignificance of this county, he taught students to play courtly music and chant the Odes, much to the master's amused approval. ${ }^{81}$ Tao Qian, however, reportedly claimed that he would consider the appointment of County Magistrate only in order to provide for his family. ${ }^{82} \mathrm{Su}$ Shi came to understand Tao Qian's official career in this light under the influence of Ouyang Fei 歐陽棐 (1047-1113), Ouyang Xiu's son and Su Shi's in-law. ${ }^{83}$ Tao's unpretentious motivation showed his true aversion to power. Understood as such, what drove Tao into officialdom was not moral or political idealism but plain and honest human need. Even more unbearable than hunger was his discovery that he took no delight in bureaucratic life; thus, he 'simply returned'.

In this interpretation, Tao Qian's behaviour was motivated solely by hunger and delight, two of the most visceral, instinctive drives of life. Its instinctiveness reveals the authenticity of his state of mind, which was unaffected by external moral teachings. This view of spontaneous morality adheres to Su Shi's

\footnotetext{
80 Su Shi, “He Tao 'Pinshi' qishou” 和陶貧士七首, no. 2, sssJ, 39.2138.

$81 \quad$ See Analects 17.3.

82 See Tao Qian's biography in “Yinyizhuan” 隱逸傳, Jinshu, 64.2461.

83 Su Shi's second son, Su Dai 蘇迨 (1070-1126), married Ouyang Fei's daughter in the third month of 1091; see Kong Fanli, ssNP, 30.970. Later that year, Su Shi was appointed the Magistrate of Yingzhou, where, at the time, Ouyang Fei was living in retreat. Towards the end of that year, during a visit, he suggested to Su Shi that Tao's "superior insight" lay in entering officialdom simply because of the lack of provisions at home; see Su Shi, "Ouyang Shubi jianfang, song Tao Yuanming shi, tan qi jueshi [...]” 歐陽叔胎見訪誦陶淵明 事嘆其絕識 [...], sssJ, 34.1815. In another poem, Su Shi describes Ouyang Fei in similar terms, "Your learning of the Way has recently gained new insight;/out of poverty, however, you now reenter officialdom” 學道新有得, 為貧仰復仕; see “Yi ping shan zeng Ouyang Shubi” 以屏山贈歐陽叔弼, sssJ, 34.1823.
} 
definition of a 'sage': the one who takes delight in the Way, not the one who knows the most about it. The 'pleasure principle' serves as an instinctive guide for one's moral behaviour. When facing tough choices in life, one should not let analytic reason interfere, but reach a decision according to one's innate inclinations. If one finds no pleasure in trying to rectify the depraved world, then one should stop trying and keep one's virtue private. As Su Shi indicates, this is the egoistical model of 'for oneself' that Tao Qian establishes.

In the late spring of 1097, Su Shi was obliged to leave his newly built house in Huizhou as he was banished farther away, across the straits to Hainan. Su Che too was banished farther away to Leizhou 雷州 (in modern Guangdong Province). The two brothers travelled together to the port and bid farewell their last farewell, as their instinct foreboded. From their youth, the two always slept in the same room when travelling; this time they spent one last sleepless night together - sleepless for Su Shi partly due to his affliction with haemorrhoids, a chronic condition he developed in Huangzhou. Su Che thus recited Tao Qian's “Stop Drinking” (Zhijiu 止酒) poem, since alcohol would have exacerbated the ailment. Su Shi later matched Tao's poem to show his resolution. ${ }^{84}$ The beginning lines recount how they both fell into their predicament:

$\begin{array}{ll}\text { 時來與物逝 } & \text { When the time comes, we depart along with things; } \\ \text { 路窮非我止 } & \begin{array}{l}\text { when the road comes to an end, we stop despite our } \\ \text { will. }\end{array} \\ \text { 與子各意行 } & \begin{array}{l}\text { You and I each took a journey at our own whim, } \\ \text { and have similarly fallen amidst a hundred barbarian } \\ \text { tribes. }\end{array}\end{array}$

With a few broad strokes of time and fate, the poem presents two brothers of extraordinary talent being swept up by powerful scourges across the central plains, briefly coming together at the margins of a landmass, only to be separated again by a surging ocean. Then, Su Shi paraphrased his brother's suggestion:

勸我師淵明
力薄且為已
微疴坐杯酌
止酒則瘳矣
望道雖未濟
隱約見津涘
When the time comes, we depart along with things; will. tribes.

84 Su Shi, “He Tao 'Zhijiu” 和陶止酒, sssJ, 41.2245-6. 
Su Shi's apology for his 'low capacity' could be read both as low tolerance to alcohol and as his limited capacity in practising the Way. Similarly, the 'way' that the poet gazes at might be read either as the actual way of banishment or, metaphorically, as the Way writ large - the ultimate truth, as encoded in the word "ford" (referring to Confucius' search for a chance to practise his philosophy in actual governance). ${ }^{85}$ In the case of Su Shi, however, his "ford" may not be the grand truth of salvaging the world, but the individual truth of ascertaining self-knowledge. This, however, awaits him only across the ocean, reachable after he abandons the central realm and all its political and cultural identities, when he will be left with himself alone.

Su Che recommended the teaching of 'for oneself' (weiji 為己) as a cure to Su Shi's ailments. This term also comes from the Analects, where Confucius states, "People of the olden times studied for themselves; people today study for others”古之學者為己，今之學者為人. ${ }^{86}$ To study 'for oneself' is the noble choice: only by enriching oneself independently of the whimsical expectations of the time can one adhere to permanent principles. While Su Shi regarded Tao Qian as a paradigm of virtue kept 'for oneself', this quotation of Confucius' exhortation might also have masked a deep change in Su Shi's political thinking - that is, a loss of faith in loyal and complete dedication to the service of the throne. Instead, a literatus, even in the role of a bureaucrat, was entitled to cultivate his private sphere outside the public realm.

This message is encoded in Su Shi's reflection on the 'Three Worthies' (sanliang 三良) who died at the funeral of Duke Mu of Qin 秦穆公 (r. 659-621 BCE). According to Zuozhuan, they were "used as sacrifice" (weixun 為殉), their deaths were mourned by the metropolitan public (guoren 國人), and opinion held it as evidence of Duke Mu's innate cruelty. ${ }^{87}$ Zuozhuan's choice of words suggests that their deaths were not voluntary, but were forced and violent. Yet the commentator Zheng Xuan 鄭玄 (127-200) hypothesised that they must have volunteered to sacrifice themselves out of loyalty. ${ }^{88}$ In 1061, during Su Shi's first official post in Fengxiang 鳳羊羽 (in modern Shaanxi Prov-

85 In Analects 18.6, Changju 長沮 and Jieni 桀溺 were ploughing the fields when Confucius passed by with his disciples. Zilu 子路 was sent to ask for directions to the ford, but was mocked by the recluses for trying to save the world when he did not even know something as simple as that.

86 Analects 14.24.

87 Zuozhuan Wen 6; see Chunqiu zuozhuan zhengyi, 19A.142, ssJzs, 1844.

88 The Mao commentary to the ode "Huangniao" 黃鳥 (Mao 131) seems to suggest that they were forced to die: "The people of the capital criticised King Mu for using humans to follow him in death" (yiren congsi 以人從死). The Zheng commentary, however, glosses congsi as “suicide” (zisha 自殺). See Maoshizhengyi, 6.105, ssJzs, 373. 
ince), he seconded Zheng Xuan's opinion in a verse on Duke Mu's tomb, which was a local tourist attraction. He maintained that the people of old had superior morality and were willing to die for the sake of being appreciated by a powerful patron. Such heroic deeds were no longer seen in his day, leading to the suspicion that their deaths were coerced. ${ }^{89}$ It should be mentioned that $\mathrm{Su}$ Che, in his matching poem, rejected Su Shi's surmise forthright, arguing that they could better repay the ruler's appreciation by serving his son, the future king; thus, these wise gentlemen could not have chosen a fortuitous death. ${ }^{90}$

Su Che's argument hinged upon the fact that the royal lineage of Qin was not severed. The moral value of loyal dedication itself was not questioned, and his poem did not represent a break with the traditional ideology of personal loyalty.

Su Shi's revised commentary upon the 'Three Worthies' came almost four decades after his initial poem. This time it was in response to Tao Qian. Tao's poem also accepted the alternative tradition that the three had committed suicide, and it related the story based on the account of Ying Shao 應劭 (fl. 153-196). In this version, Duke Mu once sighed at a happy banquet and said that he would very much like someone to share his pleasure in life and his grave in death, so the three volunteered. Their deaths were merely fulfilling their oath. ${ }^{91}$ The authenticity of Ying's narrative may be questionable, but it must have found a large audience, including Tao Qian, who was willing to think that the Worthies' choice of death was noble. Tao's poem reveals conflicting emotions. He first sympathises with their entrance into officialdom, an action he interprets as being driven by the fear of an idle life. He subtly disapproves, however, of its consequence, which is that of "being used for the ruler's personal interest”遂為君所私. Once the ruler revealed his diabolical wish at an intimate moment, they had no choice but to volunteer. The poet respects their loyalty, yet the tears that are shed onto his robe question the very value of absolute dedication to a capricious ruler. ${ }^{92}$ In this regard, Tao's resignation is a trade-off: he may risk living an idle life, but at least he preserves his most precious self.

Su Shi's response to Tao's thoughtful poem is extraordinary. He dismisses all scholastic sophistication and ambiguities, and completely overturns his youthful admiration for their loyalty. Instead, he argues that there should be a limit

\footnotetext{
89 Su Shi, “Qin Mugong mu” 秦穆公墓, in “Fengxiang baguan” 鳳翔八觀, sssJ, 3.118-9.

9o Su Che, “Qin Mugong mu” 秦穆公墓, in “He Zizhan 'Fengxiang baguan' bashou” 和子瞻 鳳翔八觀八首, Su Che ji, 2.27.

91 As quoted by Shiji zhengyi 史記正義; see Shiji, 5.195, n. 4.

92 Tao Qian, "Yong Sanliang", TYM, 4.383.
} 
to one's service to the ruler. He elaborates on the distinction between the public and the private, declaring that public service should not be equated with the ruler's private wishes, and insisting that individual life has an intrinsic value that should not be sacrificed in vain. He reasons:

\begin{tabular}{|c|c|}
\hline $\begin{array}{l}\text { 此生太山重 } \\
\text { 忽作鴻毛遺 }\end{array}$ & $\begin{array}{l}\text { The weight of this life is as heavy as Paramount Tai; } \\
\text { how all of a sudden is it discarded as a goose feather, s } \\
\text { light? }\end{array}$ \\
\hline 三子死一言 & The Three Gentlemen died for a single word - \\
\hline 所死良已微 & what they died for was truly, alas, a triviality! \\
\hline 賢哉晏平仲 & Sagacious was Yan Pingzhong, the Qi minister, \\
\hline 事君不以私 & whose service to the ruler was not personal. \\
\hline 我豈犬馬哉 & Am I a dog, or am I a horse, \\
\hline 從君求蓋帷 & that follows the king for an exquisite canopy? \\
\hline 殺身固有道 & There is a proper way to let oneself die, \\
\hline 大節要不虧 & that is, one's great integrity shall remain intact. \\
\hline 君為社稷死 & If the king died for the sake of the state, \\
\hline 我則同其歸 & I shall then follow his fate. \\
\hline 顧命有治亂 & A royal command may bring order - or chaos; \\
\hline 臣子得從違 & so the subject can opt to follow - or disobey. \\
\hline 魏顆真孝愛 & $\begin{array}{l}\text { Wei Ke['s rejection of his father's wish] showed true } \\
\text { filial affection; }\end{array}$ \\
\hline 三良安足希 & $\begin{array}{l}\text { the death of the 'Three Worthies' deserves no } \\
\text { admiration! }\end{array}$ \\
\hline 仕宦豈不榮 & Doesn't an official career bring glory? \\
\hline 有時纏憂悲 & It sometimes entails sorrow and woe. \\
\hline 所以靖節翁 & $\begin{array}{l}\text { For this very reason, the old man Jingjie [aka. Tao } \\
\text { Qian] }\end{array}$ \\
\hline 又此黔串衣 & chose instead to wear Qianlou's shabby clothing. ${ }^{93}$ \\
\hline
\end{tabular}

Of the five historical instances Su Shi cites, the 'Three Worthies' are set in contrast against wiser examples. Yan Ying 晏嬰 (?-500 BCE; polite name Pingzhong 平仲) refused to commit suicide after his ruler was murdered, since, as he ar-

93 Su Shi, “He Tao 'Yong sanliang”" 和陶詠三良, sssJ, 40.2184-5. Qianlou was a lofty, but extremely poor, recluse. When he died, he was covered with a cotton blanket that was too short to cover his head and his feet simultaneously. When someone suggested to his wife that she place the blanket diagonally to cover the whole body, she replied that it was better to be an upright person than to have adequate covering. See Liu Xiang 劉向, Lienü zhuan huibian 列女傳彙編 (Beijing: Beijing tushuguan, 2007), 2.192-4. 
gued, one should die for a king only when he has died for the sake of the state. As Duke Zhuang 齊莊公 ( $r$.553-48 BCE) died dishonourably in an act of adultery, Yan mourned for his death as dictated by ritual, but would do nothing more. ${ }^{94}$ Wei Ke 魏顆 (sixth century BCE) similarly defied his father's last wish to kill his favourite concubine as sacrifice because such blind obedience would only have tarnished his father's fine reputation..$^{95}$ The 'Three Worthies' thus failed to perform the higher moral command by using their conscientious judgement. Though Su Shi followed the alternative tradition and believed that they died for an oath, their commitment to obeying a despotic request reduced them to being their ruler's pets. The last allusions to Tao Qian and Qianlou further imply that perhaps their very choice of entering officialdom was folly. Power and glory were bought at a dear price: one's precious self.

Su Shi found in the Book of Changes the theoretical support for his new understanding on relations between ruler and subject. According to his own commentary, Hexagram 28, “Great Excess" (Da guo 大過), represents an age when the ruler is arrogant and the power of the ministers is shattered. This is because in the yin and yang binary system, the ruler is in the yang position and his ministers are in the yin position. The yang controls the yin, but it could neither exist without the yin nor deprive it of its dignity. Neither force should

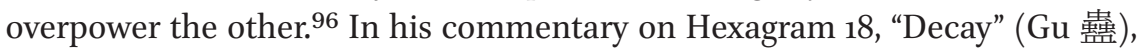
he suggests that a virtuous person shall endeavour to rescue the world when he sees the early symptoms of disaster. But, if the situation is beyond rescue, he should stay away from the kings and lords to save his own skin. ${ }^{97}$ In other words, he observes the 'timeliness' (shi 時) of retreat. As Aat Vervoorn has argued, this idea of timely service is found across the early Confucian and Daoist classics:

[It] provides a way of finding room for both periods of dutiful service and periods of lofty withdrawal in the individual's relationship with ruler and society. [...] In this way eremitism ceased to be a type of conduct which prima facie required moral justification and became something natural and inevitable, a part of the eternal order of things..$^{98}$

94 Zuozhuan Xiang 25; see Chunqiu zuozhuan zhengyi, 36.281, ssJZs, 1983.

95 Zuozhuan Xuan 15; see Chunqiu zuozhuan zhengyi, 24.186, ssJzs, 1888.

${ }_{96}$ Su Shi, Su shi Yi zhuan, in San Su quanshu, vol. 1, 232-3.

97 Ibid., 205.

98 Vervoorn, Men of the Cliffs, 68. 
Su Shi's change of attitude towards the 'Three Worthies' suggests a shift of emphasis from absolute loyalty to the value of individual life. For a traditional literatus, cultivated to think of morality as having an ultimately altruistic and public purpose, the egoistic option provided an escape into the private sphere, which may find physical abode in a garden, the fields or in a refined studio. In Su Shi's vision, this sphere was essentially an inner utopia that only a meditative mind could reach.

\section{Peach Blossom Spring as an Inner Utopia}

In his famous prose narrative with a poem, "Peach Blossom Spring", Tao Qian depicted an autonomous rural society, where residents shunned the external world and were free from governmental interference. Su Shi, alienated from his external environment and not free to complain, discovered instead an inner utopia in Tao's vision. It shared the essential features of a Daoist grotto Heaven and could only be visited by a meditative mind, regardless of location or external situation. It is, in Isaiah Berlin's term, an "inner citadel" where, by disclaiming one's desires for goals in the external world, one becomes the king of an infinite space, contained in a nutshell. One is free from the tyranny of environment, fate or an absolute monarchy - not by removing these obstacles from one's path, but by renouncing even the vaguest desire to go down that path. ${ }^{99}$

In Tao Qian's iconic record, a stray fisherman encounters a clear stream, its banks bearing groves of blossoming peach trees. Rowing against the stream, he finds a narrow entrance to a cave and, on the other side, an open space accommodating a hermetic agrarian community. It had been established centuries earlier by people escaping the warfare that arose at the end of the Qin Dynasty. The hospitable residents have a pleasurable and autonomous life, know no change of kings and pay no taxes. The fisherman goes home, breaks his oath of secrecy and then guides the Magistrate of Wuling 武陵 (in modern Changde, Hunan Province) to find the cave. But Peach Blossom Spring is never found again. ${ }^{100}$

Three prominent features contributed to Peach Blossom Spring's lasting appeal: its exclusivity, its utopic symbolism and its half-mythical, half-realistic characteristics. Its residents were humans, but their living space was similar to a Daoist Heaven. As Susan Nelson has argued,

99 See Isaiah Berlin, "Two Concepts of Liberty", in The Proper Study of Mankind (New York: Farrar, Straus, and Giroux, 2000), 206-12.

100 Tao Qian, “Taohuayuan ji bing shi”, тYM, 6.479-80. 
[Tao Qian] borrowed elements from fables about Immortals current in his day; however much he modified them, notions of the supernatural were at their origin and core. ${ }^{101}$

These supernatural associations include the peach blossoms at the entrance (intimating immortality), the tunnel entrance (suggesting a grotto heaven), the stream perhaps nourishing a 'spiritual fount', and the magical disappearance of the entrance upon one's searching for it. ${ }^{102}$ These are all common mythemes in Daoist lore. Yet, as Yim-tze Kwong has observed, though this story might be inspired by contemporaneous lore about immortals, its narrative is decidedly realistic, making Peach Blossom Spring "at once utopian and thisworldly". 103

Su Shi's reenvisioning of the Peach Blossom Spring was not just based on Tao's account and poem, but also on their extensive subsequent literary reception. From the Six Dynasties on, but particularly in the Tang Dynasty, Peach Blossom Spring became a popular poetic motif. It was used as a facile synonym either of a princely estate or a grotto heaven. The former is exemplified in the following poem from Yu Xin 庽信 $(513-581)$ :

梁王修竹園 冠蓋風塵喧

行人忽枉道 直進桃花源
The Prince of Liang's garden of slender bamboos their crowns overtop the clamour of wind and dust below.

A passenger may suddenly go astray, and intrude straight into a Peach Blossom Spring. ${ }^{104}$

Similarly to Tao Qian's vision, this Peach Blossom Spring is also an exclusive space. Ironically, however, its residents are no longer farmers escaping despotic rule, but the rulers themselves. The tall bamboos, looming over the dust and clamour, symbolise their power. The hapless passenger is a parody of the stray fisherman - hospitality surely does not await him. At best he will be expelled as a joke by the laughing Prince and his guests. Peach Blossom Spring is no longer a classless society, but a privatised, privileged space - the ruthlessness of which is revealed only upon intrusion. In other poems mentioning Peach

\footnotetext{
101 Susan Nelson, "On through to the Beyond: the Peach Blossom Spring as Paradise", Archives of Asian Art (1986), 39: 26.

102 Ibid., 25-6.

103 Kwong, "Naturalness and Authenticity", 49.

104 Yu Xin, “Fengbao Zhaowang huijiu shi” 奉報趙王惠酒詩, $X Q H W$, “Beizhou” 3.2377.
} 
Blossom Spring before the Tang, the motif all refers to an aestheticised, artificial garden. ${ }^{105}$

This use of Peach Blossom Spring extended well into the Tang Dynasty. During the Tang, Peach Blossom Spring as a literary motif gained popular currency, verging on the cliché. As an allusion and a motif, it appears in more than two hundred poems in Quan Tang shi 全唐詩, called alternatively taohuayuan 桃 花源, taoyuan 桃源, huayuan 花源, Wuling yuan 武陵源 or Wuling xi 武陵 溪. A number of these poems describe the princely estates of "weekend recluses". As Stephen Owen has argued,

[Tang estate poetry featured] an encounter of antithetical extremes, in which the center of political power [...] and the place defined by its rupture from centered political space $[. .$.$] came together.$

The example that he raises is Shen Quanqi's 沈佺期 (656?-714?) formulation: "Peach Blossom Spring meets the Ninefold Palace" 花源接九重. ${ }^{106}$ Such a suburban estate marked an exclusive space in nature, distinct from the urban. Its residents enjoyed the relative freedom afforded by their temporal distance from the centre of power - yet also, paradoxically, by their privileged access to wealth and power.

Another common use of Peach Blossom Spring in Tang poetry was as an escapist, pristine realm of transcendence. As the Southern Song author Hong Mai observed, residents in Tao Qian's original “Peach Blossom Spring” were mortals, but Tang poets generally depicted the space as a supernatural realm accommodating earthly immortals. ${ }^{107}$ Those mythemes, latent in Tao's depiction, proliferated into various combinations and elaborations. Wang Wei's "Song of Peach Blossom Spring" (Taoyuan xing 桃源行), for instance, clearly declares that the farmers who ran away from war and tyranny somehow became immortal:

\footnotetext{
105 Aside from the poem above in Lu Qinli's book, the Peach Blossom Spring is mentioned in another three poems prior to the Tang. The second poem, also from Yu Xin ("Yong huapingfeng shi ershiwushou” 詠畫屏風詩二十五首, no. 5, $X Q H W$, “Beizhou” 4.2395), refers similarly to a princely estate; the third, to a mountain villa (Xu Ling 徐陵, "Shanzhai shi" 山齋詩, $X Q H W$, “Chen” 5.2530); and the fourth, to a Buddhist temple (Kong Deshao 孔德 紹, “Deng Baimashan Humingsi shi” 登白馬山護明寺詩, $X Q H W$, “Sui” 6.2721-2).

106 Stephen Owen, "The Formation of the Tang Estate Poem", Harvard Journal of Asiatic Studies (1995), 55.1: 44, 46. Shen Quanqi's line is from “Fenghe xing Wei Sili shanzhuang shiyan yingzhi” 奉和幸韋嗣立山莊侍宴應制, QTS, 97.1054.

107 Hong Mai, Rongzhai suibi, sanbi 10.548-9.
} 
初因避地去人間 At first they escaped warfare and left the realm of man; 及至成仙遂不還 until theybecameimmortals and would neverreturn. ${ }^{108}$

Tao Qian's description of life in Peach Blossom Spring was transplanted onto other conventional themes of immortals' lives, such as dining on turtle shells, drinking stone marrow, wearing deer fur and planting jade or fantastic, efficacious plants. ${ }^{109}$ Indeed, Tao's rural utopia had become so closely associated with a Daoist Heaven that it was even listed as such in Daoist scriptures. ${ }^{110}$ Han $\mathrm{Yu}$, who chided all stories about immortals as nonsensical, nevertheless proceeded to elaborate, in great detail, on a painting of Peach Blossom Spring as a domain of immortality.111

Immortals are beings of absolute freedom - free from illness and death, and also free to transform and to act. As a grotto heaven, Peach Blossom Spring was no longer a tax-free shelter for refugee peasants (refusing those less fortunate), nor a high-society garden (refusing the lowly born), but a pleasure house for immortals (denying entrance to mortals altogether). This last vision is at once the most fantastical and the most exclusive.

In Su Shi's matching poem, ${ }^{112}$ however, he protests against the earlier tradition of depicting Peach Blossom Spring as a Daoist Heaven. He argues in the preface:

Popular legends about Peach Blossom Spring are usually overblown. If we examine Yuanming's record carefully, he only said that their ancestors came to that place to escape the warfare at the end of the Qin. So those whom the fisherman met seemed to be their descendants, not some undead people from the Qin. He also said that they killed chickens for meals. How could an immortal kill [chickens]?

108 Wang Wei, “Taoyuan xing” 桃源行, in Chen Tiemin 陳鐵民, Wang Wei ji jiaozhu 王維集 校注 (Beijing: Zhonghua shuju, 1997), 1.16-7.

109 See, e.g., Lu Zhaolin, “Guo Dongshan gukou” 過東山谷口, QTS, 42.529; Quan Deyu 權德 輿, “Taoyuan pian” 桃源篇, QTS, 329.3679; Liu Yuxi 劉禹錫, “Taoyuan xing” 桃源行, QTS, 356.3995; etc.

110 Listed as Taoyuan shandong 桃源山洞 in a “Tiandi gongfu tu” 天地宮府圖; see Zhang Junfang 張君房. Yunji qiqian 雲笈七籤 (Beijing: Zhonghua shuju, 2003), 618.

111 Han Yu, "Taoyuan tu" 桃源圖, QTS, 338.3787. Discussed also in Nelson, "Through to the Beyond", 27.

112 Su Shi, “He Tao “Taohuayuan’ bing yin” 和陶桃花源并引, sssJ, 40.2196-8. 
世傳桃源事，多過其實。考淵明所記，止言先世避秦亂來此， 則漁人所見, 似是其子孫, 非秦人不死者也。又云殺雞作食, 豈有仙而殺者乎?

Su Shi notes the residents' non-vegetarian diet and holds it central to his argument. As to be seen later, food is deeply meaningful in defining a space. Susan Nelson remarks that Su Shi was the first person who argued convincingly against describing Peach Blossom Spring as a paradise, initiating an "immortality controversy" on the nature of this place. ${ }^{113}$ Yet, while claiming to redeem the "authorial intention" of Tao Qian, Su Shi gave this theme his own twist. For him, many Peach Blossom Springs hide in the world, in secret nooks beyond reach of centralised political or cultural forces - but they are readily accessible in dreams.

An old legend has it that there was a Chrysanthemum Creek in Nanyang. The water was sweet and fragrant. There were some thirty households and they drank from its water. They all lived long, some up to one-hundred-and-twenty or -thirty years. ${ }^{114}$ Amidst Mount Qingcheng of Sichuan, there was an 'old-man village', where some had lived to see their descendants of the fifth generation. The road to this village was extremely treacherous and long-winding, so all their lives they had never tasted salt or vinegar. There grew many wolfberry trees in the stream, the roots of which were as thick as snakes and dragons. Whoever drank its water lived long. In recent years, the condition of the road has improved, so eventually the residents are able to acquire various kinds of foods and seasonings. Their life expectancy, however, has decreased. Could Peach Blossom Spring also be of that kind? Had the Magistrate of Wuling managed to find it, it would have long become a battlefield of fighting and snatching! In my opinion, there are many places like this between Heaven and Earth, not just Peach Blossom Spring. When I was in Yingzhou, I once dreamt about coming to a government building. The people there did not differ from the mundane, but the mountains and rivers formed a vista clear and vast, which was truly delightful. I looked back into the hall and found a tablet with the inscription 'Qiuchi'. Then I woke up. It occurred to me that Qiuchi used to be the homeland of the Di natives from Wudu, under the

\footnotetext{
113 Nelson, "Through to the Beyond", 27-8, and passim.

114 A story found in the "Xianyao" 仙藥 chapter of Baopuzi 抱朴子; see Wang Ming 王明, Baopuzi neipian jiaoshi 抱朴子內篇校釋 (Beijing: Zhonghua shuju, 1985), 11.207-8.
} 
protection of Yang the Irresistible. ${ }^{115}$ How did I get there? The next day I asked my retainers. One retainer called Zhao Lingshi, whose polite name was Delin, said, "Why should you ask, sir? This is a land of bliss adjunct to the Grotto Heaven. Du Fu once said, "The Qiuchi Cave has existed since age immemorial; a secret path leads to it, a minor heaven"."16 Another day, Wang Qingchen, whose polite name was Zhongzhi, Vice Director in the Ministry of Works, told me, "Once on my return from an envoy trip, I passed by Mt Qiuchi. It was nourished by ninety-nine springs and surrounded by myriad mountains. It was truly a place to hide from the world, just like Peach Blossom Spring".

\section{舊說南陽有菊水, 水甘而芳, 民居三十餘家, 飲其水, 皆壽, 或至百二三十歲。蜀青城山老人村, 有見五世孫者, 道極險 遠, 生不識鹽䤈, 而溪中多枸杞, 根如龍蛇, 飲其水, 故壽。 近歲道稍通, 漸能致五味, 而壽益衰。桃源蓋此比也歟。使武 陵太守得而至焉, 則已化為爭奪之場久矣。嘗意天壤之間, 若 此者甚眾, 不獨桃源。予在穎州, 夢至一官府, 人物與俗間無 異, 而山川清遠, 有足樂者。顧視堂上, 榜曰仇池。覺而念 之, 仇池武都氏故地, 楊難當所保, 余何為居之。明日, 以問 客。客有趙令畤德麟者, 曰：“公何為問此, 此乃福地, 小有洞 天之附庸也。杜子美蓋云：“萬古仇池穴, 潛通小有天。”他日 工部侍郎王欽臣仲至謂余曰：“吾嘗奉使過仇池，有九十九泉， 萬山環之, 可以避世, 如桃源也。”}

According to the Shuijingzhu 水經注, Qiuchi is a rocky mountain, cut steep on all sides and with only one winding narrow path leading to the peak; its peak, however, is flat, with three hundred acres of arable land nourished by a rich mountain spring. ${ }^{117} \mathrm{Su}$ Shi's dream visit to Qiuchi must have happened in late 1091 or early 1092, during his tenure in Yingzhou. Since then, Qiuchi became Su Shi's private obsession. Shortly after his transfer to Yangzhou in the spring of

115 Di was the ethnic tribe occupying this region. Wudu 武都 (in modern Gansu Province) is the name Han Wudi gave to this prefecture in 111 BCE. The Yang clan of Di came to live on Qiuchi since the end of the Eastern Han. See Chen Qiaoyi 陳橋驛, Shuijingzhu jiaozheng 水經注校證 (Beijing: Zhonghua shuju, 2007), 20.481. Yang Nandang 楊難當 (literally, 'Yang the Irresistible') was the Chief of his clan from 429-442, until he was vanquished by the Liu-Song Dynasty. His history is recorded in Sima Guang 司馬光, Zizhi tongjian 資治 通鑒 (Beijing: Zhonghua shuju, 1956), 121.3978-124.3929.

116 Quote from Du Fu, “Qinzhou zayong” 秦州雜詠, no. 14, in Qiu Zhao'ao 仇兆鰲, Du shi xiangzhu 杜詩詳注 (Beijing: Zhonghua shuju, 1979), 7.584.

117 See Chen Qiaoyi, Shuijingzhu jiaozheng, 20.481. Qiuchi is today's Mt Changyang 常羊, in modern Gansu Province. 
1092, Su Shi acquired the pair of Quichi rocks; he named them after Du Fu's poem and in recollection of his dream. ${ }^{118}$ Notably, he began the Tao-matching exercise in Yangzhou, around the same time as he acquired the rocks. His admiration of Tao's poetry and the naming of the rocks both hint at the escapist thoughts that increasingly haunted Su's mind. The Qiuchi rocks accompanied him back to the capital, through his long journey of banishment to Huizhou and Danzhou, and, eventually, on his return to the mainland. They were the daily companions by Su Shi's side, to him symbolising a world beyond.

As the story of the Chrysanthemum Creek shows, the eudaimonic character of such secret domains was protected by their exclusivity, and the intrusion of the outside world would breach its blessed isolation. As Su elaborates in his matching poem, the Peach Blossom Spring is a metaphor for an inner realm of bliss, and access to it is only possible through absolute mental tranquillity:

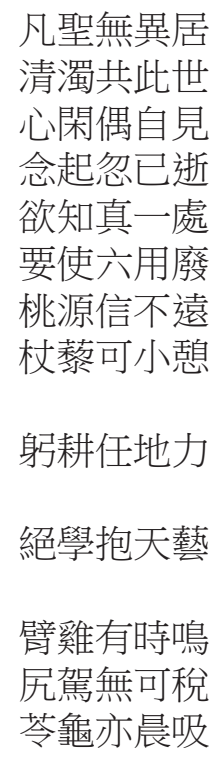

凡聖無異居 清濁共此世 心閑偶自見 念起忽已逝 欲知真一處 要使六用廢 桃源信不遠 杖藜可小㦝

躬耕任地力

絕學抱天藝

臂雞有時鳴 尻駕無可稅 苓龜亦晨吸
Commoners and sages do not differ in their residence; the pure and the foul share this same world. When my mind is idle, I catch an occasional glimpse; but when a single thought stirs, it vanishes like a flash. To find out where hides the one single truth, you must abandon your six senses!119 Peach Blossom Spring is truly not far, reachable by walking with a goosefoot stick while taking small rests.

There people farm in accordance with the capacity of the land;

they abandon learning and embrace the heavenly craft.

The arm-roosters occasionally crow;

but the thigh-carriages cannot be unfastened. ${ }^{120}$

The tuckahoe-turtles also suck the morning air;121

118 Su Shi, "Shuangshi", sssJ, 35.188o. See also ch. 3, 112.

119 See also ch. 3, fn. 29.

120 In the “Dazongshi” 大宗師 chapter of the Zhuangzi, Ziyu 子輿 becomes sick and is asked whether he feels disgusted by his deformed body. He exclaims that he shall accept all kinds of transformations that destiny dictates. If his arm was transformed into a rooster, he would let it crow to announce the time; if his thigh was transformed to a wheel and his spirit to a horse, he would ride this carriage, and so forth. See zzJs, 6.261.

121 The most efficacious tuckahoe is said to assimilate the form of a turtle. In a story related in Baopuzi, the turtle sucks in the morning air in a gingerly way and thus gains longevity; see Wang Ming, Baopuzi neipian jiaoshi, 3.48. 
杞狗或夜吠 耘樵得甘芳

齕乞素謝炮製 子驥雖形隔 淵明已心詣 高山不難越 淺水何足庽 不如我仇池 高舉復幾歲 從來一生死 近又等癡慧

蒲澗安期境 羅浮稚川界

夢往從之遊 神交發吾蔽 桃花滿庭下 流水在戶外 卻笑逃秦人 有畏非真契 and wolfberry-dogs occasionally bark at night. ${ }^{122}$

Farmers and woodcutters find sweet and fragrant things;

they eat them raw without cooking or pickling.

Though Ziji failed to tramp its soil, ${ }^{123}$

Yuanming already visited it in his mind.

High mountains are not hard to cross;

shallow waters are trivial to wade.

It cannot be compared to my Qiuchi, raised high above for how many years!

Where life and death are always treated equal;

and lately, the foolish and the clever have also become the same.

The Calamus Gully is the domain of Scholar Anqi; ${ }^{124}$

Mount Luofu is the territory of Zhichuan [aka. Ge Hong].

In dreams I follow their roaming;

the encounter of our spirits shall clear my delusions!

Peach blossoms fill an entire court;

a flowing stream outside of the door.

Now I laugh at those who escaped the Qin despot they still had fears - my true kindred spirits they were not!

A story in the Early Song compendium Taiping guangji 太平廣記 tells that Zhu Ruzi 朱 孺子, an acolyte to the Daoist Wang Xuanzhen 王玄真, once saw two spotted puppies disappearing into a cave. He told Wang and they dug into the cave together, only to find two spotted wolfberry roots. Wang told Zhu to cook them in an alchemist's tripod. After guarding the fire for three days, Zhu was enticed by the smell and drank the soup. Afterwards, he shared the root with Wang. Zhu became an immortal, while Wang only enjoyed extreme longevity. See Taiping guangji, ed. Li Fang 李昉, sKQQS, 2043.24.7-8. The same comparison of wolfberry to a dog is also used by Su Shi in "Ciyun Zhengfu tongyou Baishuishan” 次韻正輔同游白水山, sssJ, 39.2150; “Gouqi” 枸杞, in “Xiaopu wu yong” 小圑 五詠, sssJ, 39.2159.

In Tao Qian's story, Liu Ziji 劉子驥 was a recluse who also wanted to find Peach Blossom Spring, but unfortunately died before setting off on his search. See Tao Qian, "Taohuayuan ji bing shi", тYM, 6.479-80.

124 Calamus Gully is in Mt Baiyun 白雲山 (in modern Guangzhou, Guangdong Province), where the calamus grows plenty. In local legend, Scholar Anqi 安期生 found a ninegnarled calamus root that sprouted purple blossoms, ate it, and became an immortal. See Ji Han 秡含, Nanfang caomu zhuang 南方草木狀, in Han Wei liuchao biji xiaoshuo daguan 漢魏六朝筆記小說大觀 (Shanghai: Shanghai guji chubanshe, 1999), 1.256. 
In Su Shi's vision, this world of ours is both shared and divided. It is a common space from which no one can escape. But one could have a private realm, separate from the rest of the world: a secluded corner accessible only when the mind is completely void - if a single thought stirs, the entrance closes. The journey to this realm, in other words, is an exercise in mental spontaneity. Paradoxically, the ultimate mobility of spiritual roaming is achieved only in absolute tranquillity.

Living in such a realm, moreover, demands that one dispossess learning and craft. This eudaimonic life is nourished by raw, highly nutritious food. As Su Shi argues in the preface, the people of Nanyang and Qingcheng enjoyed longevity because of the medicinal properties of their water and a plain diet unadulterated by salt or spices. Despite being described as farmers and woodcutters, these residents were gatherers dining on raw food. As Campany argues, in the meaning system of Chinese cuisine, eating grains and cooking are essential characteristics of an agricultural life. ${ }^{125}$ In contrast, the 'cuisine of transcendence' is based on something other than grains, ingested raw (or prepared according to secret methods different to standard cooking techniques), and prepared and consumed ritualistically. An alternative diet is an essential component in the endeavour to transcend the sedentary, agrarian society and its political and ideological hierarchies. ${ }^{126}$ Even though Tao Qian employed Daoist mythemes to construct his Peach Blossom Spring, the chicken-killing, millet-cooking residents are physiologically human. Su Shi noted this point in his preface to support his argument that Peach Blossom Spring is not a grotto heaven. In his matching poem, however, it is precisely their cuisine that is then modified to become raw and seemingly vegetarian. Their distinctive dietary habits have now become consistent with the socioeconomic and political 'otherness' of this community.

The Daoist feature of Su Shi's Peach Blossom Spring is further underlined by its wondrous population, including arm-roosters, thigh-carriages, tuckahoeturtles and wolfberry-dogs. Human body parts, manufactured objects, plants and animals seem to be in constant metamorphosis, characteristic of the Daoist worldview. According to Isabelle Robinet, the Chinese philosophy of metamorphosis does not perceive the appearance of the world as a creation, and there is no ontological separation or discontinuity in nature. "When arriving at a terminal point of development, each thing reverses itself into its opposite or otherwise changes its form". ${ }^{127}$ Those hybrid beings under Su Shi's brush ap-

125 Campany, "Meaning of Cuisine", 8-9.

126 Ibid., 50-2.

127 Isabelle Robinet, Taoist Meditation: the Mao-shan Tradition of Great Purity, trans. Julian F. Pas and Norman J. Girardot (Albany: State University of New York Press, 1993), 154. 
pear to be caught at the most revealing moment of their transitional stage, when their forms are still fluid. This seems to imply that the vital density of this magical land facilitates the metamorphosis of things, which are thus constantly found to be in transformation. Understanding the grand transformation of things represents a "hallmark of intellectual knowledge". ${ }^{128}$ Coming to this land, one's eyes are opened as one sees the world in its true form.

Those defining features of life at Peach Blossom Spring mirror the life of a Daoist adept, whose meditative spirit roams free, who observes a raw food diet (or ideally dines upon air alone), and who partakes of the metamorphosis of things through chemical or physiological alchemy. This explains Su Shi's proposal to follow Scholar Anqi and Ge Hong - both famous in local lore - in dream and in fantasy. He laughs at the residents of Peach Blossom Spring, whose discovery was motivated by fear - an undesirable state of mind which hampers spontaneity. Aat Vervoorn writes that "[e]ssential to all eremitism is the element of free choice"; a hermit is properly called a hermit "only if his actions follow from a moral decision rather than merely the pressures of circumstance". ${ }^{129}$ Therefore, even though these farmers lived at Peach Blossom Spring, they were not practising eremitism since they were not there out of their own free will, nor did they make sacrifices in choosing their life. Yet Su Shi goes beyond extolling the freedom of choice and focuses instead on the spontaneous mental state that follows this exercise of freedom. He implies that one does not need to relinquish one's worldly abode to go into reclusion. To physically seek a separate realm is already a highly deliberate act, which can be motivated by the unease or fear in one's external environment. It is therefore an inferior form of access. Access to an inner utopia, on the other hand, is gained when one sinks into a state of non-intentionality (as in a dream or in meditation). One no longer needs to find a Peach Blossom Spring in the real world, as long as one can recreate a eudaimonic life through Daoist practice and receive all the mental and physiological bliss that comes along with it.

Compared to earlier visions of Peach Blossom Spring, which all depict an exclusive physical space, Su's is more egalitarian and more meritocratic: virtually anyone can enter, so long as they reach the level of Su's 'kindred spirits'. And, since it exists only in one's inner space, no stray fisherman or passenger can intrude. It is the ultimate 'private sphere'.

128 Robinet, Taoist Meditation, 155.

129 Vervoorn, Men of the Cliffs, 4. 


\section{Return}

In the topography of mental reality, a land of bliss is accessible only in spiritual spontaneity. Going to this land is seen as 'returning' - a return towards the original state of existence. This redefinition of 'return' might have had a therapeutic effect on Su Shi, since, as an exile, he could not physically return home. Homesickness was, for him, an unaffordable malady.

瘘人常念起 夫我豈忘歸 不敢夢故山 恐興墳墓悲
Even a paralysed person often thinks of rising how could I forget to think of return.

But I dare not dream of my homeland's mountains, lest I arouse the grief over my forefathers' graves..$^{130}$

This poem was written shortly after he arrived in Hainan. He dreamt one night of his house at White Crane Peak in Huizhou, which he was forced to abandon soon after it was built. This, as he interpreted it, was because a dream of his Sichuan hometown would be too sad to bear. The comparison of himself to a paralysed person suggests a spell he could not break. A paralysed man is imprisoned by his physical handicap; a political exile is imprisoned in the vast landscape.

As Yoshikawa Kojirō has noticed, one of Su Shi's favourite metaphors was "my life is like a sojourn only".131 Instead of indulging in nostalgia and melancholy, Su decided to resign himself to the fluctuation of life and settle in the present moment so as to ensure that his true inner life "lie[s] in a continued resistance". 132 Therefore, on one hand, as life is a constant sojourn, 'home' is but an illusion; on the other hand, with 'return' redefined as a return to one's authentic state, he is already 'home' wherever he might be. As a result, as early as in his time in Yangzhou, he attempted to regard the lack of career success as felicitous for such a return. ${ }^{133}$ In his final exile, he further argues that misfortune facilitated his recognition of his "original face":

瓶居本近危 甑墜知不完 夢求亡楚弓 笑解適越冠
The [broken] vase had always stayed close to peril; a falling pot knows that it will not remain intact. In dream I seek the bow lost in Chu; laughingly I take off the ritual hat after going to Yue.

\footnotetext{
130 Su Shi, “He Tao 'Huan jiuju” 和陶還舊居, sssJ, 41.2250-1.

131 Yoshikawa, Sung Poetry, 111.

132 Ibid., 114.

133 See Su Shi, “He Tao 'Yinjiu ershishou', no. 9, sssJ, 35.1886.
} 
忽然返自照 識我本來顔 歸路在脚底 殽潼失重關
All of a sudden, I come to see myself in the mirror, and recognise in it my original face.

The road of return has always been under my feet; the layered passes of Yao and Tong disappear. ${ }^{134}$

In the “Jifu” 跡府 chapter of Gongsun Longzi 公孫龍子, it is said that the King of Chu once lost his precious bow while hunting. When his attendants volunteered to find it, the King stopped them and said, "When a man of Chu has lost his bow, a man of Chu will find it. What is the loss?"135 This reference suggests that Su's loss of rank was not a loss at all. Likewise, in a Zhuangzian parable, a merchant of Song came to Yue with many embroidered ritual hats, an item difficult to sell to the half-naked natives. ${ }^{136}$ Laughingly taking off his own official hat, Su Shi shows his willingness to discard the accoutrements of culture, so that he could finally see his own true form. The "road of return" is not through the imposing mountain passes. Instead, his home is nowhere but in his innermost mind; thus, his feet have always been treading upon this "road of return". The geographical distance between Hainan and his Sichuan hometown is translated into psychological space, easily covered in a single thought.

In this vision, the body becomes the lodge of mental activities such as dreams, meditation and spiritual roaming. It should be well maintained to facilitate these activities. Yet anxiety over mortality lurks behind Su Shi's every thought of return, since death is its ultimate form. The following rhyme prose, “HeTao“Guiqulai xici””和陶歸去來兮辭, ${ }^{137}$ matchesTao Qian's earlier piece, ${ }^{138}$ rhyme for rhyme, and rewrites Tao's celebrated moment of homecoming, scene by scene. To a certain extent, it becomes an esoteric hymn on Daoist meditative practice.

[1] Zizhan is banished to live in Changhua [aka. Danzhou]. He matches Yuanming's "Return!" and takes the Land of Nothingness as home. Even though he is beyond the seas, he is ever returning.

\footnotetext{
134 Su Shi, "He Tao 'Dongfang you yi shi", sssJ, 41.2266. The Yao and Tong passes (both in modern Shaanxi Province) are used here as synecdoche for mountains that are difficult to cross. Wang Guan 王琯, Gongsun Longzi xuanjie 公孫龍子懸解 (Beijing: Zhonghua shuju, 1992), 1.34.

136 See the "Xiaoyaoyou" 逍遙遊 chapter in the Zhuangzi; zZJs, 1.31.

137 Su Shi, sssJ, 47.2560-1.

138 Tao Qian, “Guiqulai xi ci” 歸去來兮辭, TYM, 5·460-77.
} 


\section{子瞻謫居昌化，追和淵明《歸去來辭》，蓋以無何有之鄉為 家, 雖在海外, 未嘗不歸云爾。}

This preface intimates that the true purpose of this composition is self-persuasion. Su shows resolution to settle in "the Land of Nothingness". As discussed in Chapter Three, this land appears in a Zhuangzian parable, where a gigantic ailanthus tree could be valued exactly for being useless. "The Land of Nothingness" accommodates the one who does not belong. When the poet is attached to no place, everywhere can be "the Land of Nothingness"; Su transforms this into a pun on the material deprivation of Hainan. Yet, as Su argues, if his own settled mind is his true home, he is constantly returning.

[2] Return, return! I am freshly banished to the south, so how can I return? I lie amongst the expansion of the rivers and oceans, lamenting over the dolorous drums and horns announcing the hours. I left traces crouching in the mud, ever more deeply; gone is the time like flashes of lightning beyond my chase! I think of the southwest road to my home; dreaming is truly correct, but waking is not. I realise the inconstancy of this life, just like changing clothes at the shifts of seasons. But I shall not miss the ramie clothing of the summer when wearing winter fur, since I have rather gained big and lost small.

\section{歸去來兮, 吾方南遷安得歸。卧江海之湏洞, 中鼓角之悽悲。 迹泥蟠而愈深, 時電往而莫追。懷西南之歸路, 夢良是而覺 非。悟此生之何常, 猶寒暑之異衣。豈襲装而念葛, 蓋得觕而 喪微。}

The poem evokes Tao's famous invocation "Return, return!", only to declare it beyond the capacity of an exile. To Tao Qian's "I realise today I am correct and in the past I was not" 覺今是而昨非, ${ }^{139}$ Su responds that, for him, only dreaming is correct, since he can return home only in dreams, while his waking state is wrong, as reality forces him to face the inconstancy of life. He persuades himself to stop the vain nostalgia and settle in the present moment, arguing that his predicament is, in fact, a bargain.

[3] My return is truly facile, without galloping or rushing. In every simple action I am returning home. I get off my carriage and lock the gate. Though fences and walls have crumbled, the hall and chambers are still 
intact. I fetch my Ale of Heaven and pour it into a hollow cup. I drink moonlit dew to cleanse my heart and dine upon the morning's rosy clouds to brighten my cheeks. The 'guest' and the 'host' become one and the same, so that the 'mother- and daughter-in-law' can live in peace. I realise there is no thief or robber, so I dismantle the gate and break the lock. I expand my round mirror to reflect the external world, which contains the myriad phenomena to be observed from the middle. As I dredge the deserted well to fetch fresh water in the morning, a hundred springs surge and brim overnight. I guard the extreme tranquillity ${ }^{140}$ and let the energy rise by itself. At times it is like a leaping sparrow ${ }^{141}$ or a twirling giant salamander. ${ }^{142}$

我歸甚易, 罒馳匪奔。俯仰還家, 下车闔门。藩垣雖阙, 堂室 故存。挹吾天䣶, 注之窝尊。飲月露以洗心, 飡朝霞而眩顔。 混客主以為一, 俾婦姑之相安。知盗窭之何有, 乃掊門而折 關。廓圆鏡以外照, 納萬象而中觀。治廢井以晨波, 滃百泉之 夜還。守靜極以自作, 時爵躍而鯢桓。

Tao Qian describes himself as riding a rushing carriage to return home, showing ecstasy and urgency. By contrast, Su Shi declares himself to have no such urge. Using a rhetorical device often found in Daoist literature, he transforms the physical space of a house to the metaphor of one's body. The borrowing is facile, since 'return' is also an essential term in Daoist alchemical literature; for instance, "returning to infancy"143 suggests that human vitality is fully charged upon parturition and constantly discharges with every natural cycle of breath. ${ }^{144}$

140 Reference to Laozi 16, "Attaining vacuity in its extremity,/guarding tranquillity firmly" 致 虛極守靜篤; see Zhu Qianzhi, Laozi jiaoshi, 64 .

141 Jueyue 爵躍 is a variant to queyue 雀躍. In the "Zaiyou” 在宥 chapter of the Zhuangzi, Yun 雲 (literally 'the cloud') in his roaming, met Hongmeng 鴻蒙 (literally 'the vast nebulosity'). The latter was patting his thigh and leaping around like a sparrow, about to roam too. Hongmeng's true wisdom, it transpires, is in hiding his wisdom. See zzJs, 11.358.

In the “Yingdiwang” 應帝王 chapter of the Zhuangzi, Huzi 壶子 bewildered a shaman by appearing in various forms, and manipulated their physiognomy. He could do this because, as he explained, he was like the depths housing "twirling giant salamander", "flowing water" and "still water", among others. See zzJs, 7.302.

143 As found in Laozi 55. "One who keeps the fullness of the life force,/is comparable to a newborn child” (含德之厚比於赤子); see Zhu Qianzhi, Laozi jiaoshi, 218; cf. Edmund Ryden trans., Daodejing (Oxford: Oxford University Press, 2008), 115.

144 For more discussions on the Daoist notion of "return" or "reverse" ( $f a n$ 反), see Joseph Needham and Lu Gwei-Djen, Spagyrical Discovery and Invention: Physiological Alchemy, 
Cosmic sustenance provides pristine energy that recovers his physical and mental wellbeing. When he no longer makes a distinction between the external and the internal (the "guest" and the "host"), the conflicting forces within (the "mother- and daughter-in-law") are harmonised. He is then capable of opening himself to the myriad forms, reflecting them inside as they truly are. His body is now a miniature of the cosmos. The mirror, as discussed in Chapter One, symbolises the tranquil, spontaneous mind which has omniscient cognitive capacity. The dredging from the deserted well symbolises the rediscovery of the inexhaustible fountain of energy that flows from within. In Daoist inner alchemy, because water is an essence that maintains life and is symbolic of the Way, maintaining a constant circulation of body fluid is crucial. ${ }^{145}$ Water is also a symbol of simultaneous dynamism and tranquillity. By guarding his ultimate tranquillity, the poet finally transforms himself into a Zhuangzian figure who is an incarnation of primordial nebulosity (symbolised by Hongmeng 鴻蒙 who jumps joyously like a sparrow), or of the deepest depths (symbolised by Huzi 壼子 who hides like a giant salamander). The body becomes the physical embodiment of spontaneity.

[4] Return, return! Allow me to live through my days in this roaming voyage. My forefathers have left me this shabby hut - why should I abandon it and look elsewhere? Hainan and the central plains are truly equal; I bring myself along in comings and goings without worry. A Man at Odds gives me one wise word: there is no use for the Eight Diagrams or the Nine Laws! When a man is hungry, he needs food. When the river is crossed, discard the boat! Suddenly, the oxherd and the buffalo both disappear. ${ }^{146}$ What remain are but tall trees and high hills. With alertness,

in Science and Civilization in China, pt.5 (Cambridge, uk: Cambridge University Press, 1983), 25; also 130-5, passim; Schipper Kristofer, The Taoist Body, trans. Karen C. Duval (Berkeley: University of California Press, 1993), 119; Robinet, Taoist Meditation, 140-1.

145 See, e.g., Robinet, Taoist Meditation, 90.

146 Referring to a phase in the Oxherding Pictures: a series of paintings with colophons which depict the process of an oxherd seeking a lost buffalo. These images, metaphoric for a Buddhist practitioner seeking his self-nature, have multiple versions from the tenth to the twelfth century, and differ in their number of phases. The earliest known version is by a certain Master Qingju 清居, with five phases (some tradition has it as "eight phases"); other versions are those by Zide 自得 (1097-1183) with six phases, and by Puming 普明 (before 1021) and Kuo'an 廓庵 (eleventh to the twelfth century), each with ten phases. Su Shi's friend Foyin 佛印 (1032-1098) also seemed to have made a version with four phases. See Shi Tianhong 釋天宏, “Kuo'an 'Shiniutu song' kao: cong muniutu song tanqi” 廓 庵《十牛圖頌》考: 從牧牛圖頌談起, Shijie zongjiao xuekan 世界宗教學刊 (2011), 
the six senses stay in abandonment; from one single root, I reverse the flow. Gazing afar at my old home, I long to rest. Yet how could I have rested already thrice midway?

歸去來兮, 請終老於斯游。我先人之敉盧, 復舍此而焉求? 均
海南與漢北, 栔往來而無憂。畸人告予以一言, 非八卦與九
疇。方飢須糧, 已濟無舟。忽人牛之皆袈, 但喬木與高丘。警
六用之無成, 自一根之返流。望故家而求息, 曷中道之三休。

This paragraph continues his self-persuasion. The "shabby hut" refers to his own body which he cannot abandon. He has learned to discard divination and human norms. And after he has passed the river, even "the boat" (or 'skilful means') that he relied upon to achieve enlightenment, should be abandoned. This state of truth is illustrated in Buddhist terms as the mutual oblivion of the subject and the object of seeking (the "oxherd" and the "buffalo"). This is the moment when one abandons the six sensory faculties and returns to the common origin of myriad things. Su fears, however, that he may fail to truly return, since his capacity is weak. Even though he knows that he shall not rest, he nevertheless has stopped to catch his breath, already thrice midway. His home remains fully in view, but beyond reach.

[5] Alas, let it be! My life is destined; my return timed. I in my original state neither go nor stay. Let me say: I will go wherever you go. How can I, in following the teachings of Zhuangzi, neglect to follow Anqi's suit! How can I, because crops planted in the drought will ultimately wither, refuse to water or to cultivate the seedlings! I have taken Yuanming's elegant abandonment as my example and have written hundreds of new poems in matching rhymes. I also write the pure prelude of "Return!" - I must be his reincarnation, no doubt!

17: 123-54. Given the multiple versions circulating at Su Shi's time, it is not clear which version he might have borne in mind. In both the Kuo'an and the Puming versions, "mutually forgotten" (xiangwang 相忘) refers to the eighth phase. But the Kuo'an version represents it with a full circle - symbol of yuanxiang 圓相 - with both the oxherd and the buffalo disappearing from the picture. Given that Su Shi described this phase as "[w]hat remain are but tall trees and high hills", this was not the corresponding picture that he had in mind. Nor does it correspond to the Puming version, in which the eighth phase is depicted with the oxherd and the buffalo standing apart from each other (while the tenth phase is represented by a circle). An English discussion, translation and reproduction of the Puming pictures can be found in D.T. Suzuki, Manual of Zen Buddhism (London: Rider \& Company, 1950), 127-44. 
已矣乎, 吾生有命歸有時, 我初無行亦無留。駕言隨子聽所 之, 豈以師南華而廢從安期。謂湯稼之終枯, 遂不溉而不耔。 師淵明之雅放, 和百篇之新詩。賦歸來之清引, 我其後身蓋無 疑。

In this last paragraph, Su Shi decides to reconcile himself with his limited capacity. If Zhuangzi represents the understanding of the ultimate philosophical truth - the equation of life and death, Scholar Anqi represents another esoteric truth - that a mortal can succeed in defeating death. As a principle of Daoist alchemy, death is a curable disease. Su Shi declares that he will follow both examples. He understands the ultimate destiny of decay, but, as the analogy borrowed from Ji Kang's 嵇康 (223-263) “Treatise on Nourishing Life" (Yangsheng lun 養生論) suggests, just like a farmer shall not give up watering his crops even in a time of drought, he should not give up nourishing his own life just because every effort ends in vain. ${ }^{147}$ In the end, he claims to be Tao Qian's reincarnation; even though, when announcing their identity, Su has already modified the meaning of Tao's precedence. To 'return' in Su Shi's fashion, one must exercise oblivion and let oneself sink into a meditative, spontaneous mental state; one should also practise the Daoist art of longevity and immortality to maintain the "shabby hut" in which one is accidentally housed - ironically, to deter death, the ultimate 'return'.

\section{Coda}

Su Shi's emulation of Tao Qian held long-lasting significance. In the reception history of Tao Qian's poetry, his emulation was a crucial step which led to the gradual canonisation of Tao through the Song Dynasty. Indeed, many of Su Shi's admirers undertook writing similar poems 'matching Tao', a practice so widespread that it earned Chao Shuizhi's 昆說之 (1059-1129) mockery: "In just a single day, Tao Yuanmings suddenly swarmed in front of my eyes”陶淵明紛 然一日滿人目前矣. ${ }^{148}$ Chao insisted that it was preposterous for lesser talents to write 'matching Tao', since Su Shi alone deserved to be Tao's match. As this reverent judgment shows, Su Shi's emulation had not only elevated the status of Tao Qian, but, at least for sympathetic readers, also made himself the unique equal of Tao Qian. Emulating Tao helped the formation of Su's 'mature

\footnotetext{
147 See Dai Mingyang 戴明揚, Ji Kang ji jiaozhu 嵇康集校注 (Beijing: Renmin wenxue chubanshe, 1962), 3.143-4.

148 See Hong Mai, Rongzhai suibi, 3.32.
} 
style' (laojing 老境), characteristic for its deliberate limpidity, suppressed tension and understated aesthetics - all of which make its apparent simplicity belie rich subtlety. By stylistically 'returning' to Tao's purported simplicity, Su Shi declared himself to have fulfilled a trajectory of life 'returning' to its original spontaneity. His stylistic choice was hence, simultaneously, a moral choice.

For modern critics, Su's wistful declaration that he was Tao's reincarnation (houshen 後身) is also highly problematic. Taken at face value, it hinges upon multiple dubious assumptions: first, poetry is a mirror of the poet's true self; second, a later reader can fully grasp the precursor's truth through reading, despite the changed circumstances in which he lives; third, by writing in the precursor's style, he creates a similar literary persona, transforming himself into the faithful reproduction of the poetic persona that he emulates and recreates. Needless to say, the complete identification of the literary persona with the poet himself is a hazardous theoretical model, but it had its logical legitimacy in Su Shi's conceptual world, where poetry primarily had the expressionist value of conveying its author's moral truth.

Yet Su Shi's declaration also contains a tension that resists this straightforward reading; it begs to be taken with a grain of salt, since his model of stylistic 'return' is designed to fail. As Stephen Owen observed, since the Mid-Tang, authenticity and singularity had come to be seen as inseparable. ${ }^{149}$ While Su Shi as Tao's reincarnation may 'inherit' Tao's style, an exact reproduction would belie the singularity of both poets. And, since Tao Qian's poetry was held as the paradigm of authenticity and spontaneity, emulating this paradigm necessarily required the emulator to be truly himself. As no two individuals are completely alike, Su Shi could declare himself to have become another 'Tao Qian' only by remaining stylistically different, which, as the aforementioned comments by Yuan Haowen and Ji Yun show, he did. A thorough imitation would lay bare the artificiality of the whole project. As observed in earlier chapters, stylistic spontaneity by necessity implies individuality.

All these paradoxes point to the element of self-persuasion underlying Su's effort. To be sure, the poetic persona of the 'simple' and 'natural' Tao Qian was already highly constructed and an idealised version of the historical person. ${ }^{150}$ When Su Shi further transformed this rhetorically constructed image to make it even more simplified and symbolic, his ostentatious optimism purged those

149 Stephen Owen, The End of Chinese 'Middle Ages': Essays in Mid-Tang Literary Culture (Stanford: Stanford University Press, 1996), 20.

150 On the constructed nature of Tao's image, see Stephen Owen, "The Self's Perfect Mirror: Poetry as Autobiography", in The Vitality of the Lyric Voice, eds. Shuen-fu Lin and Stephen Owen (Princeton: Princeton University Press, 1986), 71-102. 
instances of anxiety or doubt that Tao Qian's poems occasionally betrayed. Tao Qian, in Su's narrow vision, lived a life predestined to become a metaphor one that reflected Su's longing for an autonomous self, able to choose his path in life and to move beyond immediate or existential anxieties. Summarily put, Su elevated Tao's image to cult and mythical status. By wearing this mask he constructed, he exercised an imagined power over his own fate and sought freedom from persecution, deprivation and despair. In doing so, his alleged return into nature became, paradoxically, a retreat from nature, into a cultivated inner utopia of spontaneity. 


\section{The Spontaneous Body}

Silently standing in perennial mist and tropical verdure, Mt Luofu was where the ancient Daoist Ge Hong spent his final years experimenting on an alchemical elixir that would ultimately grant him immortality. Legend had it that he succeeded. ${ }^{1}$ When Su Shi - aged, tired and disillusioned - was banished to Huizhou, he interpreted the destination of his journey as a sign of fate's urging his final commitment to the arcane science.

This book's last chapter is about the last chapter of Su Shi's life: his escape from, and ultimate reconciliation with, death. In Su Shi's conceptual world, immortals were real or possibly real beings. An immortal's body was the fully spontaneous body, free from anxiety, disease and even the restrictions of a concrete material form. If the exoteric pursuit of spontaneity ended with the model of Tao Qian, the esoteric pursuit of spontaneity ended with that of $\mathrm{Ge}$ Hong.

Mainstream Chinese literature is generally reluctant to discuss Su Shi's Daoist devotion in the last stage of his life, wary of it being 'superstitious'. ${ }^{2}$ In English literature, Ronald Egan has given this issue some well-balanced consideration. ${ }^{3}$ However, Egan did not pay heed to the periodisation in Su Shi's commitment to alchemical practices, the techniques that he employed, or the context of alchemical beliefs and practices handed down through history. Without a careful examination of such beliefs and practices, an important aspect of Su Shi's life, as well as many of his literary works (especially those writ-

1 See Fang Xuanling, Jinshu, 72.1911-3.

2 For instance, Zhu Jinghua 朱靖華 does not touch upon his Daoist practice at all. At best he only mentions his "integration" of Chan Buddhism and Zhuangzian Daoism to transcend suffering; see Zhu Jinghua 朱靖華, Su Shi xin lun 蘇軾新論 (Jinan: Qilu shushe, 1983), 13-6, 428-30. A similar case is Leng Chengjin, Su Shi de zhexue guan, 324-7. Zeng Zaozhuang 曾柊 庄, Su Shi pingzhuan 蘇軾評傳 (Chengdu: Sichuan renmin chubanshe, 1984) similarly circumvents this issue. Wang Shuizhao 王水照 only mentions how “others" suggested Su Shi practise the Daoist art of longevity; see Su Shi zhuan: zhizhe zai kunan zhong de chaoyue 蘇 軾傳：智者在苦難中的超越 (Tianjin: Tianjin renmin chubanshe, 2000), 541. He and Zhu Gang 朱剛 further maintain that Su used Daoist methods only for health reasons. See Wang Shuizhao, Su Shi zhuan, 570; Wang Shuizhao and Zhu Gang, Su Shi pingzhuan 蘇軾評傳 (Nanjing: Nanjing daxue chubanshe, 2004), 118.

3 See Egan, Word, Image, and Deed, 237-50. 
ten in Huizhou), is liable to be poorly understood. This chapter is a preliminary attempt to correct the academic oversight.

As I argue, Su Shi's pursuit of immortality was part of his efforts to explore the unknown and to fathom his fate. It was also consistent with his pursuit of spontaneity in art and in life. An 'immortal' (xian 仙) ${ }^{4}$ not only lives for an extremely long time, he also lives in complete spiritual and physical freedom. Paradoxically, in the pursuit of such freedom, every stage requires ardent ritual practice in induced meditation. Regardless of whether immortality is fated or achieved, even those whose chance of immortality is written require dedicated practice. Those less lucky may achieve extreme longevity through meticulous care. Yet, such efforts are not to 'interfere' with one's fate. To be truly spontaneous, when death comes, one should readily resign to one's fate without further ado. The pursuit of immortality reveals a dynamic structure of practice and resignation, resulting in the kind of spontaneity which is provisional and conditioned by human imperfection.

This chapter first gives a chronological account of Su Shi's Daoist devotion and examines the various techniques he used, including laboratory and physiological alchemy. Then it discusses the various literary precursors that he chose to follow, each giving a conflicting view of death and immortality. An esoteric discourse on 'the Dragon and the Tiger' practice that he wrote in Huizhou is carefully analysed; and his building of a house on the White Crane Peak is seen as the culmination of his commitment to the pursuit of immortality. However, his further exile to Hainan falsified his reading of destiny, resulting in his resolution to the active immersion in the transience, and his final resignation to fate.

\section{The Amateur Alchemist before Mt Luofu}

Among Song literati, Daoist practice in varying degrees of dedication was common. Even though the Zhao imperial house of the Song did not promote themselves as the descendants of Laozi, like the Li house of the Tang did, several emperors were devoted adepts, under whose patronage the Daoist scriptures

4 The Chinese notion of xian does not necessarily imply they never die. They may live for a few hundred years or achieve seeming immortality - that is, living as long as Heaven and Earth exist. Here, the term 'immortal' is used as an apologetic counterpart for xian, as becoming immortal is the practitioner's ultimate goal (implied in the alternative term for the Daoist art: busizhishu 不死之術, or 'the technique of undying'). 
were first collected, edited and published in an encyclopaedic fashion. ${ }^{5}$ Their effort set an example for the literati and facilitated their access to the texts.

Daoism as a popular religion permeated people's daily life. The child Su Shi was initially schooled in a local Daoist temple at Mt Qingcheng and studied with the Daoist priest Zhang Yijian 張易簡. Half a century later, exiled to Danzhou, one night he had a dream in which he went back to that temple and heard a pupil reading Laozi, ${ }^{6}$ which he must have read as a child. The greying poet remembered that, at a tender age, he was fond of Daoism. Were it not for his father, who obligated him into marriage and civil service, he would have spirited himself away into the mountains and become a hermit. ${ }^{7}$ However, retrospective memory is not always reliable. Perhaps $\mathrm{Su}$ Shi selectively magnified elements of the past to establish a consistent narrative of his life, make his final dedication to the Daoist art in Huizhou and Danzhou appear to be a certain 'return', and reduce his worldly glory to unfortunate aberration. As he said, "reading my youthful compositions, they resemble events happening in another life or the writing of someone else". ${ }^{8}$ He disowned the words that brought him fame and declared his exile an opportunity to realise his true self. By this mental device, he interpreted misfortune as the source of happiness.

As a matter of fact, Su Shi's Daoist practice before Huizhou was inconsistent and half-hearted, foreboding nothing like a final return. ${ }^{9}$ A poem written in 1059 mentioned his reading of Huangtingjing 黃庭經 (the Yellow Court Scripture), ${ }^{10}$ a canon which established the essential theories of Daoist 'inner

The first encyclopaedia of this kind, Yunji qiqian 雲笈七籤, was a collection in 120 fascicles compiled by Zhang Junfang 張君房 (jinshi 1005), and presented to Zhenzong 真宗 (968-1022; $r$. 997-1022) in 1019. It represented a 'core collection' among the anarchic assemblage of texts loosely called 'Daoist'. The imperial patronage of compiling Daoist texts continued until the end of Northern Song, culminating in the Wanshou daozang 萬 壽道藏 in 5,481 fascicles and published in block printing in 1116-17. See Chen Guofu 陳國 符, Daozang yuanliu kao 道藏源流考 (Beijing: Zhonghua shuju, 1963), 134-6. See Su Shi, “Zhongmiaotang ji” 眾妙堂記, sswJ, 11.361-2.

7 See Su Shi, "Yu Liu Yiweng shijun shu” 與劉宜翁使君書, sswJ, 49.1415-16; “Yu Wang Xiang wushou" 與王庠五首, no. 1, ssWJ, 60.1820.

8 See Su Shi, "Yu Wang Xiang wushou”, no. 1, sswJ, 60.1820

9 Zhong Laiyin's 鐘來因 Su Shi yu daojia daojiao 蘇軾與道家道敎 (Taipei: Xuesheng shuju, 1990), so far the most detailed study of Su Shi's Daoist practices, unfortunately takes his devotional acclamation uncritically and gives a partisan reading of his biography.

10 See Su Shi, “Liu ti Xianduguan” 留題仙都觀, sssJ, 1.18-9. The Yellow Court (huangting 黃 庭) is a Daoist term referring to the fictive middle space of the human body. It is named as such because yellow represents 'middle' in the Five Phases (wuxing 五行) cosmology, while the court is the (political and cosmological) middle of the world. It usually corre- 
alchemy' (neidan 內丹), or physiological alchemy. This term is dichotomous with 'outer alchemy' (waidan 外丹), or laboratory alchemy.1 The Northern Song saw a general transition from laboratory to physiological alchemy. From the second century BCE to the Late Tang, laboratory alchemy had been in dominance. Its theory, roughly speaking, was based upon using the alchemist stove as a microcosmos in which various minerals were tempered into alchemist gold. The ingestion of 'cinnabar pellets', made of alchemist gold, was supposed to transform the human body into durable materials that defied decay. ${ }^{12}$ The minerals used to make cinnabar pellets, however, were highly poisonous. Many practitioners, including emperors, were victims of 'cinnabar poisoning. Their deaths were often interpreted by Daoists - makers and peddlers of these pellets - as "deliverance from the corpse" (shijie 尸解). ${ }^{13}$ In contrast, inner alchemy recommended a safer and cheaper approach. The body of an inner alchemist was interpreted as a microcosmos itself; its various parts corresponded to cosmic elements and its functioning mimicked that of an alche-

sponds to the spleen. It is also sometimes said to consist of three parts, corresponding respectively to the middle of the brain, the heart and the spleen. See Shangqing huangting neijing jing 上清黃庭內景經, in Zhang Junfang, Yunji qiqian, 190, 197; Schipper, Taoist Body, 106; Robinet, Taoist Meditation, 57. Another theory is that three 'Yellow Courts' are located within the head, the spleen and the lower Cinnabar Field (dantian 丹田); see Robinet, Taoist Meditation, 57. Cinnabar Field refers to the source of energy in the body. It usually corresponds to the place three inches below the navel; though, according to the principle of triadic unity, there are another two cinnabar fields in the cerebral and thoracic sections of the body. See Shangqing huangting neijing jing, in Zhang Junfang, Yunji qiqian, 11.232, 235 .

Dan 丹, or elixir, literally means (red) cinnabar, since cinnabar is a main ingredient in producing alchemist gold. Here, I use the common definitions of neidan and waidan in modern scholarship; see, e.g., Needham and Lu, Spagyrical Discovery, xxiv. However, examined from a historical viewpoint, the exact boundary between waidan and neidan remains flexible, and the terminologies of laboratory alchemy are often used metaphorically in describing the process of physiological alchemy. See Isabelle Robinet, "Sur le sens des termes waidan et neidan", Taoist Resources (1991), 3.1: 4-5, 31-2. For further information, see also Farzeen Baldrian Hussein, "Inner Alchemy: Notes on the Origin and Use of the Term neidan", Cahiers d'Extrême-Asie (1989), 5: 187.

See Wang Ming, Baopuzi neipian jiaoshi, 4.71-2.

"Deliverance from the corpse" is one way a Daoist practitioner could become an immortal, that is, he pretends to have died by discarding a corpse, while his spirit roams free. See Isabelle Robinet, "Metamorphosis and Deliverance from the Corpse in Taoism", History of Religion (1979), 19.1: 37-70. According to Chen Guofu, in the Tang, many died from cinnabar poisoning and Daoist priests were aware of the harm. Thus, they produced those pellets mainly for profit, not for their own consumption. See Chen Guofu, Daozang, 383-4, 388-9, 391-2. 
mist stove. ${ }^{14}$ Inner alchemy became the mainstream since Song times. ${ }^{15}$ Su's alchemical exercise was mainly physiological. His method would eventually combine respiratory control, abstinence, meditation, gymnastics and gathering the cosmic essence of the sun and the moon, aided by the intake of herbal medicine.

In 1063, during his first official tenure at Fengxiang, Su Shi had the opportunity to visit the Daoist library in the Shangqing Taiping Temple 上清太平宮, and read its collection of scriptures. He depicted a rich library of a thousand boxes wrapped in blue silk, which he must have read selectively. He seemed to be primarily interested in meditation techniques. ${ }^{16}$ If this library also collected books on laboratory alchemy, he did not mention them.

Yet his early interest seemed to reflect more intellectual curiosity than belief. In the two decades prior to his Huangzhou exile, Su Shi remained an inactive practitioner. In contrast, his younger brother, Su Che, started practising inner alchemy from 1071 (because of his lung disease), and showed great dedication. ${ }^{17}$ In 1077, when they met in Xuzhou, Che surprised Shi by his achievement in practice. ${ }^{18}$ Su Shi admired Che's focus, as he himself was easily distracted. ${ }^{19}$ Only after he was exiled to Huangzhou did he take a solemn oath to abjure worldly engagement and sensual pleasures. At the end of 1080, further alarmed by his eye disease and early signs of ageing, he retreated to the Daoist Tianqing Temple 天慶觀 for an uninterrupted forty-nine days of meditation. ${ }^{20} \mathrm{He}$ blithely told his disciple, "Were it not for the dismissal and exile, how could I have managed to do this?" 21

One practice that Su Shi attempted in Huangzhou was to gather the cosmic essence of the sun and the moon. In the Daoist universe of general correspondences, the body is a microcosmos in a triadic unity (sanyi 参一): the cerebral, the thoracic and the abdominal. ${ }^{22}$ The sun and the moon, as heavenly bodies,

14 See Robinet, Taoist Meditation, 82. For graphs representing an alchemist body, see Needham and Lu, Spagyrical Discovery, 68-72.

15 See Zhong Laiyin, Su Shi, 4-7; Chen Guofu, Daozang, 393-4.

16 Su Shi, “Du daozang” 讀道藏, $s s s J, 4.181-2$.

$17 \operatorname{sSN}, 89$.

18 Ibid., 147, 155 .

19 See Su Shi, “Chubie Ziyou” 初別子由, sssJ, 15·757-9.

20 See Su Shi, “Yu Teng Dadao liushibashou” 與滕達道六十八首, no. 22, sswJ, 51.1481-2; “Da Qin Taixu qishou” 答秦太虛七首, no. 4, sswJ, 52.1535.

21 Su Shi, "Da Qin Taixu qishou", no. 4, sswJ, 52.1535.

22 According to Isabelle Robinet, the polyvalence of symbols is caused by their applicability to different levels or stages in the process of progressive spiritualisation, depending on where the adept starts his meditation (whether focus is on the lower or upper part of the 
metaphorically refer primarily to the eyes (located in the cerebral section), but also to inner lights shining upon the landscapes in the practitioner's middle and lower body sections. Methods of this practice vary. But, in general, such methods recommend standing facing the sun or the moon and visualising its presence, circulation and accumulation inside the human body - often accompanied by respiratory control and salivary deglutition. ${ }^{23} \mathrm{Su}$ Shi aimed to absorb the cosmic essence to strengthen the corresponding organs in the body. ${ }^{24} \mathrm{He}$ might only have read about such practices from books, as he admitted that he did not know the proper mantra accompanying this practice - so he invented one himself. ${ }^{25}$ Oral transmission contributes to the self-perpetuating mystery of the occult science. Daoist canons are often written in deliberated abstruse language or in ecliptic fashion, so that orally transmitted mantras (koujue 口訣) are necessary in order to understand the written instructions. ${ }^{26}$ Su Shi's 'invention' of a mantra seems to suggest either his extreme confidence or utter playfulness.

Encouraged by his progress in physiological alchemy, Su Shi eventually requested cinnabar from his old friend and fellow practitioner Wang Dingguo 王定國, 27 who lived in Guangxi. He had ambitions to make the elixir of immortality: 'the Golden Cinnabar' (jindan 金丹). ${ }^{28}$ He seconded the argument that true immortality is attainable only by taking the Golden Cinnabar, or 'Great Drug' (dayao 大藥), a theory advanced by Ge Hong in Baopuzi 抱朴子 (Master Who Embraces Simplicity). Ge Hong argued that herbs and other efficacious natural materials were all 'minor drugs' (xiaoyao 小藥) that only guaranteed longevity, but not genuine xian-hood. ${ }^{29}$ Only by taking the cinnabar, tempered nine times in the alchemist stove (or by taking multiple doses of cinnabar tempered fewer times), could the practitioner take his thoroughly

body); see Robinet, Taoist Meditation, 52 . This triadic unity of the body can be explained by the principle of "Three-One"; see ibid., 125-6, 187-8.

See Zhang Junfang, Yunji qiqian, 23.532-8. Needham and Lu called it "actino-therapeutic complex" or "phototherapeutic procedures"; see Spagyrical Discovery, 31-2, 181-4.

On such practices, see Needham and Lu, Spagyrical Discovery, 182-4.

Su Shi, “Cai riyuehua zan” 採日月華贊, sswJ, 21.617.

26 As exhorted by Ge Hong; see Baopuzi neipian jiaoshi, 14.155-6; mentioned also in Fabrizio Pregadio, Great Clarity: Daoism and Alchemy in Early Medieval China (Stanford: Stanford University Press, 2006), 80.

Wang Dingguo was Su's childhood playmate who was keen in practising the Daoist art. See Su Shi, “Zai Pengcheng ri yu Dingguo wei Jiuri Huangzhou zhihui [...]” 在彭城日與 定國為九日黃樓之會, sssJ, 35.1904.

28 Su Shi, “Yu Wang Dingguo sishiyishou” 與王定國四十一首, no. 8, sswJ, 52.1517-8.

29 See "Jindan", Baopuzi neipian jiaoshi, 4.70-2. 
transformed body to transcendence. Wang Dingguo might have tried to dissuade Su Shi from making the elixir at home, when Su Shi urged him to send cinnabar twice more. ${ }^{30} \mathrm{Su}$ Shi reassured him that he would never dare take the pellets, but making them would entertain him in idleness. As will be seen later, it is likely that he continued his secret experiments in Huizhou, a fact that suggests his long-lasting, albeit cautious, fascination with laboratory alchemy.

After his Huangzhou exile, the death of Shenzong brought him back to the centre of politics. Su spent the following eight years in a series of successful metropolitan appointments. Efficacious medicines were sometimes presented to him in return for a favour or a price. Once he received a 'flesh fungus' (rouzhi 肉芝) that had the form of a baby's arm. According to Ge Hong, taking a 'flesh fungus' guaranteed immediate immortality. ${ }^{31} \mathrm{Su}$ Shi cooked it and preciously shared it with his brother. The promised immortality, however, did not come. Instead of doubting the efficacy of the elixir, Su Shi suspected that immortality could not be won so easily. He wrote a poem to lament that, like an old silkworm trapped in its cocoon, he was only dreaming of the supreme beings with vain intensity. ${ }^{32}$ Surely, if the Great Drug could be offered or purchased, then the realm of transcendence would have long been teeming with the powerful and the rich. He also speculated that perhaps he should not have cooked it, as herbal elixirs were better digested raw. ${ }^{33}$

In the metropolitan days, his schedule filled with official and social obligations, Su Shi's practice of meditation was sporadic. He lamented that his "square-inch [Cinnabar] Field is overgrown with thorny shrubs" and longed to return to his "authentic nature". ${ }^{34}$ Thus, when his career suffered yet another abrupt strike, Su Shi optimistically interpreted it as an opportunity, as well as a mandate, to reengage with his long-abandoned pursuit. Better still, he was exiled to Huizhou, the cinnabar-producing site where Ge Hong attained transcendence. He saw it a sign. On crossing the Dayu Range 大庒嶺, a fortressed mountain separating the miasmic Guangdong from the central plains, he wrote:

一念失垢污

身心洞清淨

浩然天地間
A single thought purges all stains of filth; the body and mind become thoroughly pure. Between the lofty Heaven, the vast Earth,

\footnotetext{
$30 \quad$ Su Shi, "Yu Wang Dingguo sishiyishou", no. 9, no. 12, sswJ, 52.1519, 1520.

31 See "Xianyao" 仙藥, Baopuzi neipian jiaoshi, 11.201.

32 See Su Shi, “Shizhi” 石芝, sssJ, 37.2001-2.

33 See ch. 4, 153 .

34 Su Shi, “Liubie Jian daoshi Gongchen” 留別蹇道士拱辰, sssJ, 33.1765.
} 

惟我獨也正
今日嶺上行
身世永相忘
仙人拊我頂
結髮受長生

I am solitary and just.

Today I am crossing the mountain range, and shall since forget my origin, my past. The immortal lays his hand on my head, tying my hair into a knot, I hereby receive the endless life. ${ }^{35}$

The poetic persona resembles Qu Yuan, the slandered moral hero, as well as $\mathrm{Li}$ Bo 李白 (701-762), the 'exiled immortal'. The last couplet is borrowed from a poem by Li Bo on his way to exile in Yelang 夜郎 (now Huaihua, in Hunan Province). Li's poem fictively recalls his admission into the rank of immortals; 'by mistake' he indulges himself in sensual pleasures and is banished to the world of man. ${ }^{36} \mathrm{Su}$ Shi, citing Li Bo's poem, wishes to return to the state of blessed purity. Written at the moment of crossing the symbolic boundary between the centre and the periphery, this poem sublimates his sense of guilt, announces his innocence, and expresses a resolution to transcend mundane losses or gains.

As a man of letters, Su was convinced of his destiny only in reference to precedence. Another precedence was established by Bo Juyi:

Letian [aka. Bo Juyi] once built a thatched hut in $\mathrm{Mt} \mathrm{Lu}$, also intending to make cinnabar pellets. When his undertaking was about to succeed, the stove and the tripod exploded. The next day, an edict arrived, appointing him Magistrate of Zhongzhou. So he knew that businesses in and out of the world were incompatible. I have had a similar resolution for a long time but never succeeded. It was also because my business in the world had not failed. Now it has thoroughly failed. The Documents says, "What man desires, Heaven grants". It proves to be true.

\section{樂天作盧山草堂, 蓋亦燒丹也, 欲成而爐鼎敗。來日, 忠州刺 史除書到。乃知世間、出世間事, 不两立也。僕有此志久矣, 而終無成者, 亦以世間事未敗故也, 今日真敗矣。《書》 曰：“民之所欲，天必從也。”信而有徵。37}

Su Shi, “Guo Dayuling” 過大庾嶺, $s s s J, 38.2056-7$.

36 See Li Bo, "Jing luanli hou tian'en liu Yelang yi jiuyou shuhuai zeng Jiangxia Wei Taishou Liangzai” 經亂離後天恩流夜郎憶舊游書懷贈江夏韋太守良宰, Li Taibai quanji 李 太白全集 (Beijing: Zhonghua shuju, 1977), 11.567 . 
In a pattern now familiar to us, Su Shi argued that Heaven was felicitous to let him be exiled, so that he could realise what he had always desired. His exile was as much fated as willed. In this way, he claimed agency for his suffering and, rhetorically, became the master of his fate.

\section{Reading Destiny}

In Huizhou, Su Shi worked more intensively on his commentary on the Book of Changes. His commentary very definitely broke away from the Zhouyi cantongqi 周易參同契 (Concordance of the Three, Commentary on the Book of Changes) ${ }^{38}$ tradition that read this classic in 'imagery and numerology' (xiangshu 象數) terms, and had had an important influence on inner alchemical works since the Tang. ${ }^{39} \mathrm{Su}$ Shi was not interested in calculating fate. He admitted in a treatise that the Changes was initially a divinatory book and numerology was important in carrying its message; yet Confucius' commentary (xici 繫辭) set up an example of rationality, ${ }^{40}$ and $\mathrm{Su}$ Shi's followed suit. He argued that speculating about one's fate was not only difficult (if not impossible), but also superfluous. Fate (ming 命) had nothing to do with human aspiration ( $z h i$ 志); one could only employ oneself to the utmost extent of one's abilities, and allow whatever came to come. By doing so, however, there was a chance that human endeavours could overcome heavenly mandated fate. ${ }^{41}$

Yet, even if fate is unknowable, there are only three possibilities concerning the ultimate question of death: immortality, (extreme) longevity or (normal) mortality. These three aspirations are respectively represented by the theories of three figures whom Su Shi regarded as his paragons: Ge Hong, Ji Kang and Tao Qian.

Ge Hong argued that human cognitive capacity is limited, so the origin of things or immortality is beyond our perceptive scope. What is observable, however, is the constancy of transformation. It follows that a man can transform his corruptible body into something more durable, so that he will live

38 A work credited to a certain Wei Boyang 魏伯陽 of Late Eastern Han, but perhaps written by different hands and compiled over time. On the author and periodisation of this book, see Wangu danjing wang: Zhouyi cantongqi sanshisijia zhushijicui 萬古丹經王：《周易 參 同契》三十四家註釋集萃, eds. Meng Naichang 孟乃昌 and Meng Qingxuan 孟慶軒 (Beijing: Huaxia chubanshe, 1993), 30-48.

Su Shi's occasional reference to the Cantongqi system was not necessarily due to his study of this work, given that Cantongqi was a seminal work whose system prevailed in discussions of inner alchemy.

41 Su Shi, Su shi Yi zhuan, in San Su quanshu, vol. 1, 283-4, 290. 
longer or forever. ${ }^{42}$ And, since all men are endowed with the same luminous intelligence (mingzhe 明哲), everyone can potentially become an immortal. ${ }^{43}$ As it is said that Ge Hong became an immortal on Mt Luofu, Su Shi wrote on his first excursion to this mountain:

\section{東坡之師抱朴老 The Old Man Who Embraces Simplicity is truly Dongpo's teacher; \\ 真契早已交前生 our true correspondence has been bound in a former life. \\ 玉堂金馬久流落 I have long wandered away from Jade Hall and Golden Horse Gate; ${ }^{44}$ \\ 寸田尺宅今歸耕ｎow I return to a foot-high house and plough a square- inch field. ${ }^{45}$}

The "foot-high house" and "square-inch field" refer simultaneously to a tiny estate and, in Daoist parlance, to the face and the cinnabar field in the abdomen. It also implies that, consistent with his contemporary development, Su Shi rejected Ge Hong's preference for chemical alchemy and instead preferred inner alchemy. Yet Su lauded Ge Hong for his universalist approach to immortality, seeing it as evidence of the latter's Confucian compassion for all beings:

$\begin{array}{ll}\begin{array}{l}\text { 稚川雖獨善 } \\ \text { 愛物均孔顏 }\end{array} & \begin{array}{r}\text { Though Zhichuan holds his virtue to him alone, } \\ \text { his compassion for things is just like that of Confucius } \\ \text { and Yan Hui. }\end{array} \\ & \begin{array}{l}\text { He wants to let those cicada-like beings of short lives, } \\ \text { 欲使蟪蛄流 }\end{array} \\ \text { 知有龜鶴年 } & \text { know about the longevity of turtles and cranes. }{ }^{46}\end{array}$

Ronald Egan mistakenly interprets this poem as Su Shi questioning Ge Hong's 'worldly' pursuit of longevity. ${ }^{47}$ In effect, Su Shi literally borrows from Ge Hong. Arguing against an interlocutor who chides Ge's effort as futile, since no cica-

42 See "Lunxian" 論仙, Baopuzi neipian jiaoshi, 2.12-2. This argument is against Wang Chong's 王充 (27-97?) theory that immortals did not exist, since spiritual existence was not independent of the physical body; see Huang Hui 黃暉, Lunheng jiaoshi 論衡校釋 (Beijing: Zhonghua shuju, 1990), 20.871-3.

43 See "Duisu" 對俗, Baopuzi neipian jiaoshi, 3.46-54. The same argument is reiterated in Lunheng jiaoshi, 13.239-40.

44 The Jade Hall and Golden Horse Gate were buildings in Western Han palaces, and implied high academic positions in court.

45 Su Shi, “You Luofushan yishou shi erzi Guo" 游羅浮山一首示兒子過, sssJ, 38.2069.

46 Su Shi, “He Tao 'Du Shanhaijing”, no. 2, sssJ, 39.2130-1.

47 Egan, Word, Image and Deed, 243. 
da's life can be prolonged to over a year, Ge retorts that creatures like turtles and cranes can live forever (a popular belief); as beings are in constant transformation, just as birds become clams or rotten grass becomes fireflies (other popular beliefs), ${ }^{48}$ why cannot a cicada change into a turtle or a crane? ${ }^{49}$

Yet Ge Hong's confidence in everyone's capacity to achieve immortality contradicted Su Shi's agnostic view that human cognitive capacity is limited. When Su Shi doubted that everyone could become an immortal, he resourcefully quoted Ji Kang who, in the "Treatise on Nourishing Life", argued that immortals did exist; however, only a chosen few were predestined for transcendence. Normal people, with extreme care, could extend their lifespan by up to one thousand years. ${ }^{50} \mathrm{Su}$ Shi repeatedly copied this treatise by hand. In a colophon to his handwritten copy, he wrote:

In the dimming sunlight among mulberries and elms, with the remnant of a life consumed by worries and suffering, Layman Dongpo has finally begun to study the Way. Though those of supreme understanding may laugh at me, it is still a wise thing to do for myself. Since Ji Shuye's [aka. Ji Kang] "Treatise on Nourishing Life" hits precisely upon my weakness, I have made a few hand-copies of it $[\ldots]$

\section{東坡居士以桑榆之末景, 憂患之餘生, 而後學道, 雖為達者所 笑, 然猶賢乎已也。以嵇叔夜《養生論》頗中余病, 故手寫數 本 $[\ldots]^{51}$}

Ji Kang's argument, as cited earlier, is that it was a moral mandate to take care of one's physical wellbeing, just as a farmer should diligently irrigate his crops - even during a drought when their withering was inevitable. Even though not everyone may achieve immortality, one could prolong one's life significantly, up to a thousand years. Many understood, but could not practise, this doctrine because the demand was strict and the reward was remote. ${ }^{52} \mathrm{Su}$ Shi was especially touched by the 'crop' analogy and borrowed it a few times in his poetry. ${ }^{53}$

48 The "Yueling" 月令 chapter of the Book of Rites states that in the third month of summer, rotten grass turns into fireflies; in the third month of autumn, a sparrow dives into the water to become a clam. See Sun Xidan 孫希旦, Liji jijie 禮記集解 (Beijing: Zhonghua shuju, 1989), 16.456, 17.477.

49 See "Lunxian", Baopuzi neipian jiaoshi, 2.12-4.

$50 \quad$ See Dai Mingyang, Ji Kang ji jiaozhu, 3.143-4.

$51 \quad$ Su Shi, “Ba Ji Shuye 'Yangshenglun' hou” 跋嵇叔夜養生論後, sswJ, 66.2056.

$5^{2} \quad$ Ji Kang, "Yangshenglun", see Dai Mingyang, Ji Kang ji jiaozhu, 3.144-5, 154.

53 See ch. 4,161 . 
Even though such devotion might have appeared foolish to those wise ones, he swore to do it for his own sake.

As for the third possibility, namely that whatever he did would ultimately fail, Su Shi turned to the example of Tao Qian, his primary role model of the time. Tao Qian famously proposed, à la the Zhuangzi, to

$\begin{array}{ll}\text { 縱浪大化中 } & \text { Surrender to the tide of the Great Transformation, } \\ \text { 不喜亦不懼 } & \text { with neither delight nor yet fear. }{ }^{54}\end{array}$

In a poem where Su Shi first lauds Ge Hong's gospel that immortality is within every man's reach, he also then praises Tao Qian precisely for his lack of desire for immortality. Despite Tao's average lifespan, he "shared the lofty mind of the Cinnabar Hills” 雅志仍丹丘; disregarding the distinction between life and death, he transcended the flow of life. Tao and Ge represented two kinds of transcendence: the spiritual and the physical. At the end of the poem, Su Shi proposes to embrace both their models simultaneously, which suggests an ambiguity towards both attitudes. ${ }^{55} \mathrm{He}$ also announced that the three of them should form a new 'Picture of the Three Gentlemen' (sanshi tu 三士圖). ${ }^{56}$ This famous topos in Chinese painting originally depicts the collegial society of Tao Qian, the Buddhist patriarch Huiyuan 慧遠 (334-416) and the Daoist master Lu Xiujing 陸修靜 (406-477). ${ }^{57}$ Given the disparity between their times, this is mere legend. Nevertheless, it represents an ideal of friendship - based upon spiritual altitude and disregarding intellectual or religious persuasion. Su Shi now wanted to form another triadic society on Mt Luofu, with two authors whose different understandings of fate were, for him, equally true. ${ }^{58}$

54 Tao Qian, “Shen shi” 神釋, in “Xing ying shen” 形影神, TYM, 2.67.

55 Su Shi, “He Tao 'Du Shanhaijing'”, no. 3, sssJ, 39.2131.

$5^{6}$ See Su Shi, “He Tao 'Du Shanhaijing”, no. 1, sssJ, 39.2130.

57 It was said that Huiyuan, during his secluded residence on $\mathrm{Mt} \mathrm{Lu}$, never crossed Tiger Creek (Huxi 虎溪) regardless of the guest's rank. One day Tao and Lu paid a visit. They were so immersed in animated discussion that, when sending the two guests off, Huiyuan was unaware that he had crossed Tiger Creek. The tiger roared in warning and the three gentlemen laughed. See “Donglin Shiba gaoxian zhuan” 東林十八高賢傳, せ no. 1543, 78.119c. See also the entry on Tiger Creek, Wu Zongci 吳宗慈, Lushan zhi 盧山志 (Nanchang: Jiangxi renmin chubanshe, 1996), vol. 1, 103-4.

58 Even though Su liked Ji Kang's treatise, he did not seem to have taken Ji as a role model, perhaps because Ji Kang was executed. His violent death would bode ill for an exile. 


\section{Discourse on the Dragon and the Tiger}

Soon after his arrival at Huizhou, Su Shi suffered again from severe haemorrhoids, a chronic ailment that had been torturing him for decades. To alleviate the pain, he followed a strict daily diet of unseasoned noodles, and crushed tuckahoe paste mixed with black sesame. Since a meagre diet was recommended for longevity, Su Shi - again - thanked his condition for giving him the extra incentive to do what he should. ${ }^{59}$ As many immortals supposedly acquired transcendence in seeking a cure for their disease, Su Shi wistfully thought that his haemorrhoids might be a blessing in disguise. ${ }^{60}$

In addition to this diet, Su Shi sought to acquire efficacious medicine. His major benefactor was Cheng Zhicai 程之才, his maternal cousin who was appointed Judicial Commissioner of Guangdong. Given the feud between the two families, ${ }^{61}$ Su's prosecutors probably dispatched Cheng to inflict further suffering upon Su. Cheng, however, used it as an opportunity to repair their broken family ties. In the extant seventy-four letters that Su sent to Cheng in just ten months, ${ }^{62}$ a large number concerned exchanges of various types, including food, medicine and dietary supplements, as well as items obviously for laboratory purposes: mercury, sulphur, pine oleoresin, iron stove and pan. ${ }^{63}$ These letters provide precious evidence of Su Shi's possible engagement in esoteric practices, otherwise unmentioned in his writing.

Su Shi was ostensibly more at ease in writing about physiological alchemy. His most extensive and systematic treatment on this topic is found in a "Discourse on the Dragon and the Tiger, or Lead and Mercury" (Longhu qiangong shuo 龍虎鉛录說). ${ }^{64}$ Written as a private letter to Su Che, this discourse carefully recounts an oral revelation from a certain 'hermit' (yinzhe 隱者) in 1096. The fact that Su Shi frequently referred to this revelation during this period, in various forms and degrees of exotericity - in a discourse, a treatise (to be dis-

59 See Su Shi, "Da Huang Luzih wushou" 答黃魯直五首, no. 4, sswJ, 52.1533; "Yu Cheng Zhengfu qishiyishou” 與程正輔七十一首, no. 53, sswJ, 54.1612.

6o See Su Shi, "Yao song” 藥誦, sswJ, 64.1985.

61 Su Shi's elder sister was married to Cheng Zhicai and soon died, allegedly from maltreatment; see $S S N P$, 1.31. The Sus and the Chengs thus severed communication.

62 See Su Shi, "Yu Cheng Zhengfu qishiyishou", sswJ, 54.1589-621; "Yu Cheng Zhengfu sanshou” 與程正輔三首, sswJ, yiwen 佚文 3.2488-9.

63 See Su Shi, "Yu Cheng Zhengfu qishiyishou", no. 28, no. 55, no. 71, sswJ, 54.1599, 1615, 1621.

64 Su Shi, "Longhu qiangong shuo", sswJ, 73.2331-3. 
cussed later), three poems ${ }^{65}$ and, perhaps, also orally ${ }^{66}$ - underlines its significance. This discourse received certain attention in Western scholarship, but a complete translation with commentary is, so far, missing. ${ }^{67}$ Below, I will translate and discuss the text in four sections.

[1] The life and death of humans all result from [the interactions of] the kan and li trigrams. When kan and li are coupled, we live; when they separate, we die. This is a law of necessity. Kan corresponds to the heart, and li to the kidneys. What the heart recognises as correct is always upright. This is the case with even [evil-doers like] King Jie and Robber Zhi. Their being Jie and Zhi was because their internal drives were weak, while their external drives were strong. Therefore they constantly practised what their hearts recognised as incorrect. When the kidneys are strong, their influence overflows; hence rise desires. This is the case with even [sages like] King Yao and Yan Hui. Their being Yao and Yan was because their internal drives were strong, while their external drives were weak. Therefore, they constantly practised what their hearts recognised as correct. From this point of view, the nature of the heart is disciplined and upright, while the nature of the kidneys is licentious and evil. Likewise are the virtues of water and fire. Zichan once said, "Fire is fierce, thus people, at the sight of it, fear it. Water is weak, thus people fiddle with it in disrespect". 68 The wise men of the old all knew it well. The dragon is the mercury, the semen and the blood. It comes out of the kidneys and hides in the liver. It is a kan substance. The tiger is the lead, the breath and the strength. It comes out of the heart and is fostered by the lungs. It is a li

65 Three poems written in this period seem to be related to this revelation. See Su Shi, "Haishangdaoren chuan yishenshouqi jue” 海上道人傳以神守氣訣, sssJ, 40.2209-10; “Zeng Chen Shoudao” 贈陳守道, $s s s J, 40.2210-1$; and “Biandao ge” 辨道歌, $s S s J$, 40.2211-2.

66 According to his note "Haishangdaoren chuan yishenshouqi jue", Su sent this poem to Wu Ziye 吳子野, a fellow student of Daoist alchemy, in the first month of 1097; but, before that, he had already orally imparted its content to Wu in detail. See Zha Shenxing's 查慎 行 commentary under the title of this poem, sssJ, 40.2209.

67 Arthur Waley translated part of this discourse as evidence that alchemy in Song China came to mean "a system of mental and physical reeducation", see Arthur Waley, "Notes on Chinese Alchemy, Supplementary to Johnson's 'Study of Chinese Alchemy', Bulletin of the School of Oriental Studies (1930), 6.1: 15. Waley's translation and argument are also quoted in Needham and Lu, Spagyrical Discovery, 22. Ronald Egan has discussed the general alchemical principle of the discourse, but does not translate the first two sections which outline this procedure in detail; see Egan, Word, Image, and Deed, 239. 
substance. When the heart is set in motion, pneuma and strength arise together. When the kidneys overflow, semen and blood are emitted together. Just as smoke coming out of fire will never return into the wood [what is released will never return]. Common people do not study the Way. Their dragon often comes out of water, so when the dragon flies away, their share of mercury lightens. Their tiger often comes out of fire, so when the tiger escapes, their share of lead is exhausted. This is the constant principle of human life. Those who follow this course die. Those who reverse it become immortals. Therefore the Man of Truth says, "Following this course is humanity; reversing this course is the Way". And again, "The art of reversing the Five Phases, is to let the dragon come out of fire. When the Five Phases run reverse - in water the tiger is born". ${ }^{69}$

人之所以生死, 未有不自坎、離者。坎、離交則生, 分則死, 必然之道也。離為心, 坎為腎, 心之所然, 未有不正, 雖然、 跖亦然。其所以為桀、跖者, 以内輕而外重, 故常行其所不然 者爾。堅強而溢, 則有欲念, 雖堯、顔亦然。其所以為堯、顏 者, 以内重而外輕, 故常行其所然者爾。由此觀之, 心之性法 而正, 腎之性淫而邪, 水火之德, 固如是也。子產曰：“火 烈, 人望而畏之。水弱, 人狎而侮之。”古之達者, 未有不知 此者也。龍者, 寽也, 精也, 血也。出於婜, 而肝藏之, 坎之 物也。虎者, 鉛也, 氣也, 力也。出於心, 而肺生之, 離之物 也。心動, 則氣力隨之而作。腎溢, 則精血隨之而流。如火之 有烟, 未有復反於新者也。世之不學道, 其龍常出於水, 故龍 飛而永輕。其虎常出於火, 故虎走而鉛枯。此生人之常理也。 順此者死, 逆此者仙。故真人之言曰： “順行則為人, 逆行則 為道。”又曰: “五行顛倒術, 龍從火裏出。五行不順行, 虎 向水中生。”

Among the eight trigrams in the Book of Changes, the qian 乾, kun 坤, kan 坎 and $l i$ 離 trigrams have acquired the foremost significance in Daoist alchemy. In Zhouyi cantongqi, qian and kun are the 'parents' of all hexagrams, representing Heaven and Earth; but as origins they are hidden. Kan and li are their observable, exoteric manifestations in the transformations of the phenomenal world. ${ }^{70}$ In the microcosmos of the human body, kan and li represent the binary vital forces. Death results from their daily separation, and immortality is

69 Cited from a certain Taoist immortal, Taibai zhenren 太白真人; see Shi Jianwu, 施肩吾, Sishan qunxian huizhenji 西山群仙會真記, 1.10 .

70 Meng Naichang, Wangu danjing wang, 1, 26-7. 
achieved only by reversing this natural course. Su Shi further relates these two primary forces to characterology. According to his physiological interpretation of human nature, the nature of a sage is not essentially different from that of common people. The nature of sages and villains alike consists of the same kan and $l i$ forces. The $l i$ force is the strongest in a sage, while in a villain, it is the kan. Yet both forces are needed to be human. Sages control, but do not eliminate, the evil power within each and every man. This theory of human nature provides a pseudo-scientific foundation for his ethics, as discussed in Chapter One. The heart and the kidneys are the respective hosting organs of $k a n$ and $l i$ forces. Lead and mercury, also called the 'true (or vital) lead' (zhenqian 真鉛), and the 'true (or vital) mercury' (zhengong 真录), ${ }^{71}$ are their manifestations; tiger and dragon, metaphors of their power. ${ }^{72}$ In the forms of ferocious animals, the two forces devour human vitality from within. They are tamed if harmonised by each other. As the verse suggests, once the natural course of the Five Phases is reversed, the heart and the kidneys shall generate their opposite forces.

'Reverse' (fan 反) or 'return' (gui 歸) is a key notion in physiological alchemy. 'Returning to infancy' is an ancient Daoist slogan, as found in Laozi, ${ }^{73}$ suggesting that human vitality is fully charged upon parturition and constantly discharges with every natural cycle of breath. In the Daoist vision of human life, a person is born at the moment of conception - thus a child's age is determined not from the date of parturition, but from the beginning of gestation. A child therefore leads an 'inner life' inside the womb. This embryonic stage provides a model for a person's whole lifespan. ${ }^{74}$ As Robinet puts it,

[the human body is] the product of the condensation of the breaths of the Nine Heavens which are knotted into essence and are transformed into spirit which is then transformed into man. ${ }^{75}$

71 These are to be distinguished from actual lead and mercury used in chemical alchemy, as chemical alchemical and physiological alchemical terms are often used interchangeably; see Needham and Lu, Spagyrical Discovery, 22-4. On the 'true' (or vital) lead and mercury, see ibid., 25, 49, 6o, and passim.

Such a scheme of general correspondence is a concrete case of how the Five Phases system is applied in physiological alchemy; see Schipper, Taoist Body, 35 .

73 Laozi 55: “He who has in himself abundant virtue is comparable to an infant" 含德之厚 比於赤子, see Zhu Qianzhi, Laozi jiaoshi, 218.

74 See Schipper, Taoist Body, 119.

75 See Robinet, Taoist Meditation, 140-1. 
These congenital knots, however, are also the "death-roots of the womb", which plant a morbid breath into man. These germs of death must be ontologically cut off by breathing techniques. Thus, the alchemical process is to retrace "one's steps along the road of bodily decay"76 by forming an immortal embryo within, so as to ultimately replace the adept's mortal body.

If the course of life and death is natural, would not reversing it be 'unnatural', violating an essential message of Daoism? Ji Kang's "Treatise on Nourishing Life" strongly argues that the normal course of life is considered 'natural' only by "people of mediocre intelligence or less". ${ }^{77}$ The Daoist adept instead follows secret principles of nature unseen by common eyes. Su Shi does not make this statement explicitly, but he does agree, through quotation, that it is merely "human" to follow the natural course, while it is in the true Way to reverse it, echoing the argument in Laozi: "Returning is the movement of the Way" 反者道之動. ${ }^{78}$ The Daoist thus claims to follow the esoteric rule of nature.

[2] A hermit taught me, "One shall sit upright, clench one's fists and settle one's mind. When the breath becomes quiet, slowly subdue it. ('Bodhidarma's embryonic-respiration practice'also requires subduing the breath. ${ }^{79}$ If one waits for it to stop by itself, as suggested in Buddhist sūtras, I am afraid that the mercury will not reach [the heart and the lungs].) Then, although one has nothing in mind, one feels tall and luminous, courageous and fierce, like a fire which cannot be attacked. When one breath exhausts, let the air penetrate slightly; with a quiet breath, subdue it again. (When the air is about to penetrate, limit it to one breath; once this breath returns, ${ }^{80}$ it has already descended into the Cinnabar Field.) Do it. The more, the better; the longer, the greater you will accomplish. Within ten days, you shall feel the Cinnabar Field warm with water brimming upward. The longer you practise it, the warmer it feels, almost to the extent of boiling, swelling like a fountain, vegetating like clouds, steam-

76 Needham and Lu, Spagyrical Discovery, 25; also 130-5, and passim.

77 See Ji Kang, "Yangshenglun", Dai Mingyang, Ji Kang ji jiaozhu, 3.152.

78 Laozi, ch. 40; see Zhu Qianzhi, Laozi jiaoshi, 165.

79 Embryonic respiration means to breathe through neither mouth nor nose, but through the navel, like a foetus in the womb; see Needham and Lu, Spagyrical Discovery, 145-6. "Bodhidarma's embryonic-respiration practice" refers to a method prescribed in Taixijing 胎息經, which recommends “stopping the qi” 氣住. See Huanzhen xiansheng 幻真先生, Taixijing zhu 胎息經註, in Daoxue jinghua 道學精華, 129-31.

80 This refers to the believed circulation of the breath in the body, not the actual respiratory circulation as described in modern biology. 
ing into your Mud Ball. ${ }^{81}$ It is because li means 'to adhere, ${ }^{82}$ as it is in the nature of things to catch fire once adhered [to fire]. My eyes are attracted to forms, my ears to sounds, my mouth to flavours, and my nose to fragrances, so that fire follows and adheres to them. Now if I rest in quietude without being attracted to anything external, there will be nothing for the fire to adhere to. Then where does the fire go? The water is its consort, so it will necessarily follow the water. Kan means 'a hollow'. It is in the nature of water to receive things whenever they arrive, let alone being the consort of the fire. When water and fire unite, fire will not burn and water will naturally swell. This process is the so-called 'the dragon comes out of fire'. When the dragon comes out of fire, the dragon will not fly, and the mercury will not exhaust. In just over ten days, your brain will be full and your waist and feet will feel light. When you practise breath control, constantly curl your tongue backward to lick your uvula. Even though it might not reach it, maintain the mindfulness, and eventually it will reach it. Keep practising, and the mercury [namely, saliva] will trickle into your mouth. When you practise breath control, rinse [the accumulated saliva] and turn it into steam; wait until it fills your mouth and then swallow it. (If it is not yet full, keep it in your mouth and wait for the next cycle.) Send it with hollowed breath into the lower Cinnabar Field and constantly nurture it in your mind. Longer, it will transform into lead. This is the socalled 'in water the tiger is born'."

有隱者教予曰：“人能正坐, 暝目調息, 握固定心, 息微則徐 閉之。（達摩胎息法, 亦須閉。若如佛經, 待其自止, 恐丞不 能到也。）雖無所念, 而卓然精明, 毅然剛烈, 如火之不可 犯, 息極則小通之, 微則復閉之。（方其通時, 亦限一息, 一 息歸之, 已下丹田中也。) 為之。惟數以多為賢, 以久為功, 不過十日, 則丹田溫而水上行, 愈久愈温, 幾至如烹, 上行如 水, 揫然如雲, 丞于泥丸。蓋離者, 麗也, 着物而見火之性 也。吾目引淤色, 耳引於聲, 口引於味, 鼻引於香, 火軴隨而 麗之。今吾寂然無所引於外, 火無所麗, 則將焉往? 水其所妃 也，勢必從之。坎者，陷也，物至則受，水之性也，而況其妃 乎? 水火合, 則火不炎而水自上, 則所謂 ‘龍從火裏出”也。

Terminology referring to a brain cavity situated three inches behind the central space between the eyebrows. See Robinet, Taoist Meditation, 125.

82 In the Book of Changes, the trigram $l i$ 離 is explained as $l i$ 麗, that is, to 'adhere to', just like the sun and the moon 'adhere' to the sky, or the vegetation 'adheres' to the soil. See Zhouyi zhengyi, 3.31, ssJzs, 43 . 


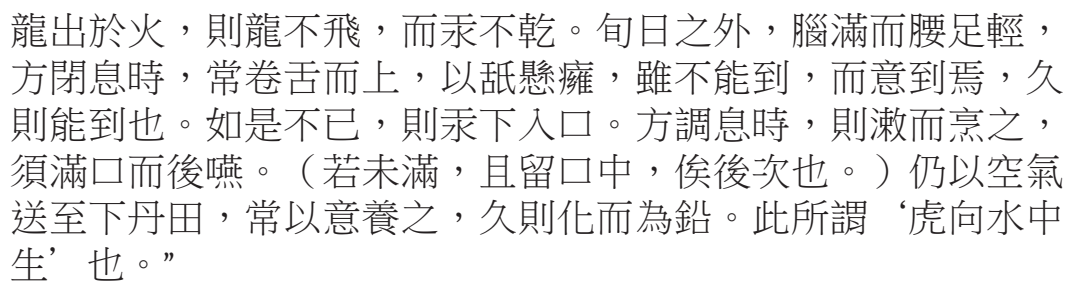

Here, an anonymous hermit came to transmit the occult science. What is curious, however, is the dearth of instructions. His message can be boiled down to two points: a practitioner shall subdue his breath and lick his uvula. Since it was a letter addressed to Su Che, it was hardly likely that Su Shi withheld information from his brother. Possibly, since Su Che was an experienced practitioner, he knew how to supplement the missing routines. This is why the only interlineal notes by Su Shi himself are in regard to breath control, saliva production, the debate of different techniques and suggestions of strategies. The rest, though ostensibly mystical and fabulous, requires no explanation to a selective, informed audience. More significant for the insiders are those deceptively simple tricks.

One point is made on whether to subdue (bi 閉) or to stop (zhi 止) the breath. According to Needham and Lu, pre-Tang respiratory control recommended holding the breath to the extent of stopping it, which might have resulted in unfortunate, even mortal, accidents. Thus, since the Tang, breathing became secondary to an imaginative voluntary circulation of $q i$ through the internal organs, assisted by aerophagy (fuqi 服氣). The practitioner swallows air and forces its circulation in his intestinal tract, where it is supposed to be melted and recast. ${ }^{83}$ Su's suggestion of swallowing saliva with "hollowed breath" into the abdomen must be a form of aerophagy. ${ }^{84}$

The method of licking the uvula to produce saliva is mentioned by the Daoist physician Sun Simiao 孫思邀 $(581$ ? -682 ? $){ }^{85}$ Saliva is precious nectar in physiological alchemy. It is variously called the 'divine juice' (lingye 靈液), 'gold liquor' (jinli 金醴), and 'pure water of the jade pool' (yuchiqingshui 玉池 清水) in the Yellow Court Scripture. Saliva performs two complementary func-

\footnotetext{
83 See Needham and Lu, Spagyrical Discovery, 147-50.

84 Su Shi was acutely interested in breathing control techniques. He also wrote about this topic in “Li Ruozhi buqi” 李若之布氣, sswJ, 73.2333-4; “Shiqi gong qishu” 侍其公氣術, sswJ, 73.2334; “Yangshengjue” 養生訣, sswJ, 73.2335-6; “Taixifa”胎息法, sswJ, 73.2337-8.

85 Sun quoted Xianger 想爾, the legendary immortal, who recommended, "Reverse your tongue into the throat, then rinse the trickle and swallow the saliva” 反舌塞喉漱漏咽液; see Sheyang zhenzhong fang, in Zhang Junfang, Yunji qiqian, 737.
} 
tions. The first is the rinsing of the mouth; the second is "the nourishment of immortality in the course of meditation". ${ }^{86}$ It is treated as the water-of-life which irrigates and moistens the body. Further, as Needham and Lu suggest, hyper-salivation makes air-swallowing easier. Salivary deglutition arose under the Tang, when aerophagy was added to breath-retention as part of breathing control practice. ${ }^{87}$ Saliva, as liquid jade, is the yin part of the couple 'jadegold'. ${ }^{88}$ After it is tempered in the furnace of the body, as Su Shi suggests, it will turn into lead, the yang or 'gold' element. The 'true lead' transformed from saliva is the tiger born in water.

This same "hermit" was very likely the "Daoist from over the seas" mentioned in a highly cryptic poem by Su Shi, written in 1096, called, "A Daoist from over the seas has taught me a mantra to guard my vital pneuma with spirit". 89 This poem is possibly related to the "Discourse on the Dragon and the Tiger". As discussed earlier, receiving an orally transmitted mantra is crucial for a Daoist adept. Without it, he may fumble among exoteric texts, oblivious to their true meaning. Writing compromises the esoteric nature of an oral transmission. Therefore, as a versified version of the oral teaching that Su received, this poem was very likely not intended to be understood, even though it slyly shares the secret.

[3] This theory is unusual yet reasonable, wondrous yet simple. Its credibility is beyond question. But I have a big problem. In my life I have made such oaths hundreds of times, all to no avail. In my opinion, this art cannot be accomplished unless one practises it with total devotion of the body, receives its teaching in one's hollowed heart, and abides by its command until the end of one's life. Now, I am already sixty, my reputation and career ruined, separated from my brother and sons, living in a barbaric country, with no prospect of returning north. The insipid flavour of this world - I know it all! I would not be man if I kept on neglecting this call. So, in the last few days, I have made an oath anew. Think of an ancient person who hid in a desolate mountain to escape havoc or was sent on a mission into remote territory, feeding upon grass or snow - how is it like to be such a man! I have ordered a meditation couch and two big

\footnotetext{
86 Robinet, Taoist Meditation, 90.

87 See Needham and Lu, Spagyrical Discovery, 150-1.

88 See Robinet, Taoist Meditation, 90.

89 See Su Shi, “Haishangdaoren chuan yishenshouqi jue" 海上道人傳以神守氣訣, sssJ, 40.2209-10. One reading of this esoteric poem is offered by Zhong Laiyin, Su Shi, 168-9. However, I am not convinced by Zhong's interpretation.
} 
desks to put under a bright window solely for this purpose. I have had a hundred cakes steamed and aired dry. From the first day of the second month on, I shall abjure all human affairs. Whenever I feel hungry, I will eat those cakes only, drink no soup or water and accept no other kinds of food. I shall chew slowly to nurture saliva and drink only a sparing amount of wine. After midday, I shall take a short nap. I shall lie at the first watch and rise at the third, sitting to watch for the dawn. When the sun rises, I shall gather the essence of the sun; when the moon rises, that of the moon. In the remaining time, I will either count my breath and temper the yin force within, or practise the dragon-and-tiger formula related above. If I do it for a hundred days, I might achieve something. I shall neither read nor write - put it aside for the future. I shall not excurse to mountains or rivers. I shall not receive any guest, or drink with people other than accomplished practitioners of the Way. All such things do me no good. But I fear deeply that my undisciplined nature will ultimately prohibit this oath from being fulfilled. So I write it down beforehand to let you know, so that I would not dare break this promise, lest I feel shameful in front of my own dear brother. But this matter is very difficult indeed! I do not know whether I might end up feeling ashamed after all. This letter thus intends both to strengthen my resolution and to inspire you, my brother.

此論奇而通, 妙而簡, 决為可信者。然吾有大患, 平生發此志 願百十包矣, 皆繆悠無成, 意此道非捐軀以赴之, 㓤心以受 之, 盡命以守之, 不能成也。吾今年已六十, 名位破敗, 兄弟 隔絕, 父子離散, 身居蠻夷, 北歸無日, 區區世味, 亦可知 矣。若復謬悠於此, 真不如人矣。故數日來, 别發誓願。譬如 古人避難窮山, 或使絕域, 㱖草啖雪, 彼何人哉! 已令造一禪 榻、兩大案, 明牕之下, 專欲治此。并已作乾蒸餅百枚。自二 月一日為首, 盡絕人事。飢則食此餅, 不飲汤水, 不啖食物, 細嚼以致津液, 或飲少酒而已。午後, 罟睡。一更便卧, 三更 乃起, 坐以待旦。有日採日, 有月採月, 餘時非數息煉陰, 則 行今所謂龍虎訣爾。如此百日, 或有所成。不讀書著文, 且一 時閣起, 以待異日。不遊山水, 除見道人外, 不接客, 不會 飲, 無益也。深恐易流之性, 不能終踐此言, 故先書以報, 庶 幾他日有慙於弟而不敢變也。此事大難, 不知其果能不慙否? 此書既以自堅, 又欲以發弟也。

Su Shi's practice includes a dry-cake-and-wine diet, a rigorous schedule, gathering the cosmic essence, respiratory control and the dragon-and-tiger 
physiological exercise. Saliva and wine are the only allowed sources of liquid. Wine is a crucial supplement in a Daoist diet. Su Shi related that his fellow practitioner, Wu Ziye 吳子野, had undertaken a diet of eating nothing, but drinking a certain "Authentic One Wine" (zhenyijiu 真一酒), to aid the "Heaven-Made Drug” (tianzaozhiyao 天造之藥) formed through physiological alchemy. ${ }^{90}$ Wine helps the circulation of blood and is thus perceived as a yang substance related to blood and semen, in contrast to saliva, a yin substance. Drinking them, and them alone, facilitates the practitioner to achieve the inner cosmic balance. Aside from the liquids, Su Shi proclaims he will eat only unflavoured dry cake, lest his appetite be aroused. ${ }^{91} \mathrm{He}$ repeatedly swears his absolute commitment, only to add a disclaimer towards the end; which begs the question: would he really succeed?

[4] Curling one's tongue to lick the uvula is a method that I recently learned. At first I rather cherished it and kept it secret. This is what the Chan teaching says, "The upward way cannot be imparted, even if you beg a thousand sages". My understanding is truly laughable, but it is very effective. After a few days of practice, unfortunately, the tendon under my tongue has sharp pains. It needs to be domesticated first to perform this challenge. If the tip of my tongue can really reach the uvula, then it will be the fastest way to fetch water from the Blossom Pond. ${ }^{92}$ [The Daoist] also said, "This method is called 'a patch of snow above a melting stove'". Keep it a secret at least for now.

\section{卷舌以舐懸㿈, 近得此法, 初甚秘惜之。此禪家所謂 “向上 一路子, 千聖不傳人”, 所見如此, 雖可笑, 然極有驗也。但 行之數日間, 舌下筋急痛, 當以漸馴致。若舌尖果能及懸 㿈, 則致華池之水, 莫捷於此也。又言：“此法名”烘爐上一 點雪”。”宜且秘之。}

The last passage appears too jovial to be serious. Immortality would have been achieved were it not for a banal hardship: an untamed tongue. Yet the poet

90 See Su Shi, “Zhenyijiu ge” 真一酒歌, sssJ, 43.2359-62.

91 On the harm of flavoured food, see Taiqing huangting zhongjing 太清黃庭中經, in Zhang Junfang, Yunji qiqian, 339.

92 Another term for the mouth, or the "Jade Pond" (yuchi 玉池). It acquired this name because the Daoist practitioner used his tongue to stir the saliva that had accumulated below his tongue until foam had formed; he then had to swallow the foam. The white foam is thus compared to "jade" or "blossom". See Shangqing huangting neijing jing 上清 黃庭內景經, in Zhang Junfang, Yunji qiqian, 284-5. 
pleads his brother, and all the future readers, to keep the secret, while he is revealing it in indelible, written words.

Su Shi was fond of scribbling down the secrets of longevity. To what extent he practised these methods remains doubtful. He seemed to lack faith in his perseverance. In another letter to Su Che, he similarly relates a few newly learned methods. Yet the true purpose is to adjure Che, the quiet and resolute one, to become an immortal first, so that Su Shi might become an immortal by association. ${ }^{93}$ It rings of political sarcasm, since $\mathrm{Su}$ Che was banished because of his association with Su Shi. According to Huang Tingjian, though Su Shi was always fascinated by the Daoist art, he could never abide by a certain prescription for a long period of time; a certain 'Daoist from over the seas' called him a "banished immortal". ${ }^{94}$ Huang's colophon raises the likelihood that the same Daoist transmitted his secret to Su because of Su's destined candidacy for immortality. It may also explain why his method is so emphatically simple: it was designed for the distracted Su Shi to follow. Yet even so, judging from his selfdiagnosis (not to mention the Spartan diet), the reader has good reason to suspect Su's failure.

This discourse is written in a private voice, which is all the more remarkable when compared to "A Sequel to the "Treatise of Nourishing Life" (Xu yangshenglun 續養生論), ${ }^{95}$ homage to Ji Kang's aforementioned treatise. The treatise shares the same theoretical framework as Ji's discourse and, at times, repeats it verbatim. But the private voice is replaced by a public one, featuring elaborated theoretical constructions and canonical quotations. The "Sequel" mentions neither Su's personal commitment or self-doubt, nor the highly technical details. The second treatise, in short, is exoteric and written for the public.

Could the private voice also be a disguise? A joke sometimes hides earnestness. Su Shi's resolve to become an 'earthly immortal' is confided in a letter written to his fellow practitioner Wang Dingguo. It declares:

Single-mindedly, I hold on to the doctrines of 'abstaining from study and having no worries', 'returning to the root', and 'guarding the One. ${ }^{96}$ Only then there is no such One to guard. Other than this is nothing but illusion. Please do not think this devotion dubious and remote. If I can indeed practise it, I shall see daily gains. Even at its most useless I shall at

\footnotetext{
93 See Su Shi, “Ji Ziyou sanfa” 寄子由三法, sswJ, 73.2339.

94 See Huang Tingjian, “Ti Dongpo shu daoshu hou”, 25.646.

95 See Su Shi, "Xu yangshenglun", sswJ, 64.1983-5.

96 Quotations from Laozi, 20, 16 and 10; Zhu Qianzhi, Laozi jiaoshi, 76, 65 and 37.
} 
least become an Earth-roaming immortal. It is only that I must humiliate myself to live a dog's life [literally, "crawl through a dog's hole"]. Please do not tell anyone else. I only want you, my dear friend, to understand me.

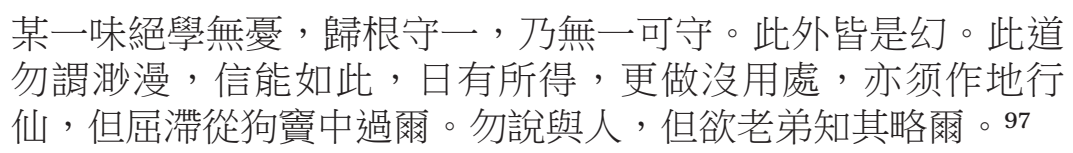

The "dog's life", as suggested elsewhere, ${ }^{98}$ includes starvation, dining upon raw plants, and abstention from all sensual pleasures. It invites ridicule from those who hold the pursuit of immortality in contempt. Nevertheless, Su Shi is willing to endure these material and mental sufferings for his own good - a secret resolution confided only to family and friends.

\section{The Daoist on White Crane Peak}

In Huizhou, Su Shi was not in charge of his life. When he first arrived, the local magistrate hosted him in Hejiang Tower 合江樓, a guesthouse that usually welcomed commissioners from the central court. Since accommodating an exile there was a possible transgression, a week later Su moved into Jiayou Temple 嘉祐寺, a secluded location on the eastern bank of the Western Riverlet. ${ }^{99}$ His wellbeing had substantially improved since Cheng Zhicai's arrival and, within half a month, Su moved back into the Tower. In early 1096, Cheng was abruptly recalled, possibly because news of their repaired family ties had reached the court. As a consequence, Su Shi moved back into the Jiayou Temple.

Su Shi's housing options reflected alternative interpretations of his worth: as a fallen genius or a condemned criminal. To take his fate into his own hands, after the New Year of 1096, Su Shi began to build a house on a deserted Daoist temple compound on White Crane Peak 白鶴峰 at Mt Luofu, ${ }^{100}$ where Ge Hong became an immortal. Su Shi's meaningful choice showed a desire to transcend the various interpretations of his identity that had been externally forced upon him. A poem, written after construction had began, envisions a

97 Su Shi, "Yu Wang Dingguo sishiyishou", no. 41, sswJ, $5^{2.1531 .}$

98 See Su Shi, “Anqisheng” 安期生, sssJ, 43.2349-50.

99 For the account of Su's life in Huizhou, here and below, see SsNP, 33.1178-245.

100 See Su Shi, “Xinnian wushou” 新年五首, sssJ, 40.2181-3. 
life above the clouds and above the worldly imbroglio. ${ }^{101}$ By early 1097, his villa on White Crane Peak was finished. He planted fruit trees, sent for his other sons, and was ready to spend the rest of his life there à la Ge Hong. He expressed this wish in a liturgical text written for the 'installing the beams' (shangliang 上梁) ceremony, which celebrates the completion of the house: ${ }^{102}$

[1] The myriad households of Goose City ${ }^{103}$ are scattered at the crossing of two rivers; the lonely peak of White Crane Temple stands above a thousand cliffs. Mirage Mountains float in the ocean like phantasms. Immortals and transcendents soar into the sky in constant traffic. In olden times there was a solemn temple called a blessed place. It nourished lush greens and became a foxes' den. Things prosper and decline; at times they appear or hide. Banished ten thousand $l i$ to the south, Master Dongpo has been hosted here for three years. He has no intention of returning and even plans to die here. He has mountains crossed and trees cut; he has come to the north against the river. In his neighbourhood is an ancient town, surrounded by crenellated walls and facing the peak from the south. His gaze sends off returning sails until the end of the horizon; a falling moon hangs ahead of his couch. He is about to open the Ink Pond of Yishao ${ }^{104}$ and to set up the cinnabar stove of Zhichuan. After a thousand years away from home, he has finally returned together with Ding Lingwei. ${ }^{105}$ Having a house the size of a single furrow, he idly records this residence of Yang Xiong. Now with the hundred walls erected, ${ }^{106}$ he rides a carriage to arrive at the pair of front gate columns. Clerics and laymen all observe this occasion, and the whole village comes to his aid. He wishes to feast these respectful elders upon chicken and pork in this rural banquet; he forbids children to harass the neighbours' geese or ducks. How could you decline the joy of a single bout of laughter? Let us tie the bond of eternal pleasure!

\footnotetext{
101 Su Shi, “Qianju” 遷居, sssJ, 40.2194-6.

102 Su Shi, “Baihe xinju shangliangwen” 白鶴新居上梁文, sswJ, 64.1989-90.

103 Aka. Huizhou, namesake of a Flying Goose Mountain (Fei'eling 飛我鳥嶺) that fringes the southwest of the city, strategically the highest point of the urban area. Aka. Wang Xizhi. See ch. 2, fn. 17.

105 According to Soushen houji 搜神後記, Ding Lingwei 丁令威 was a legendary Daoist who transformed into a crane and went home. See Soushen houji 搜神後記, ed. Wang Shaoying 汪紹楹 (Beijing: Zhonghua shuju, 1981), 1.1.

106 The term “a hundred walls" 百堵 comes from the Ode "Hongyan” 鴻雁 (Mao 181); see Maoshi zhengyi, 11.163, ssJzs, 431.
} 


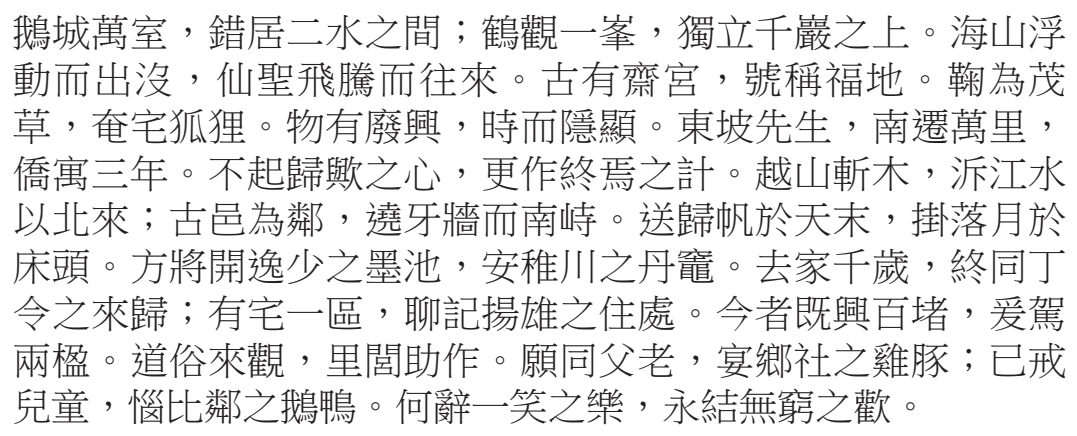

The opening lines depict the singularity of White Crane villa, its imposing location symbolising transcendence and eternity. The vicissitude of things on this ground is a metaphor for the poet's fate, at times yinxian 隱顯 (meaning 'to hide or appear', or 'to retreat or prosper'). Banished to the Far South, Su Shi had fallen from grace (xian) to humiliation (yin). And through another transformation he changed from a hapless exile into a self-sufficient Daoist hermit. What he retained from his former identity is that of a man of letters, symbolised by the comparison of his house to that of Wang Xizhi, the calligrapher, and of Yang Xiong, the classicist. The second reference alludes to Su's writing of a commentary on the Book of Changes during this period. Otherwise, he is a would-be immortal who 'returned' by transforming himself into a crane. At the end of the paragraph, the ex-bureaucrat, poet and would-be immortal disguises himself in the role of a farmer-recluse. Like another Tao Qian, he hosts a banquet and toasts farmers from his neighbourhood. The text then turns lyrical:

[2] My good boys! Throw [the grains] to the east of the beams! Where the tall trees grow into the sky used to be a Buddhist or Daoist temple. Men all say - the master sleeps soundly in the spring; strike lightly the fifth-watch, ringer of the temple bell!

My good boys! Throw [the grains] to the west of the beams! A slender rainbow bridge rides across an emerald river. When the magistrate at times comes to ask for the Way, lantern lights scatter along the long bank till the depth of night.

My good boys! Throw [the grains] to the south of the beams! Ancient trees on the south riverbank cast shades on a swirling pond. Everyone laughs at the grey-haired master, who is planting in person two orange trees to the south of the house. 
My good boys! Throw [the grains] to the north of the beams! Reflections of the mountains sway upon the north river waves. The master builds in person a fishing terrace. For a whole day he entertains himself with the water, never enough.

My good boys! Throw [the grains] above the beams! The jade-like moon and pearl-like stars shine upon a canopy of orchids. Next year the master will again build a Terrace of Gazing at the Immortals. The misty empty mountains form a gate for the retinue of clouds.

My good boys! Throw [the grains] below the beams! A well is dug, the vegetable garden ploughed, and the neighbourhood banquet now dispersed. Thousand-year-old wolfberry dogs wail long at night. On the cinnabar ladder stretching into the sky, who is being transformed into a feathered one?

兒郎偉, 拋梁東。喬木參天梵釋宮。盡道先生春睡美, 道人輕 打五更鐘。

兒郎偉, 拋梁西。嫋嫋虹橋跨碧溪。時有使君來問道, 夜深燈 火亂長堤。

兒郎偉, 拋梁南。南江古木蔭回潭。共笑先生垂白髮, 舍南親 種兩株柑。

兒郎偉, 拋梁北。北江江水搖山麓。先生親築釣魚臺, 終朝弄 水何曾足。

兒郎偉, 拋梁上。璧月珠星臨萬帳。明年更起望仙臺, 縹紗空 山隘雲仗。

兒郎偉, 拋梁下。鋀井疏畦散鄰社。千年枸杞夜長號, 萬丈丹 梯誰羽化。

Liturgical texts for the 'installing the beam' ritual, as found in some other Song anthologies, generally follow the same formula: beginning with a prose narrative of the construction of the building, followed by verses that begin with the trisyllabic incantation of a direction, either with or without the phrase erliangwei 兒郎偉 ('My good boys!'), and ending with prose prayers for auspiciousness. In the repetitive opening line(s) of each stanza, the only variant is the character for the six directions, vertical and horizontal, representing the whole 
cosmos. The word for the direction also fixes the rhyme for each stanza. This liturgical formula might well be accompanied by the actual action of children throwing agricultural produce in each direction of the beams. The rest of the stanza is heptasyllabic, rhyming at the end of the third and the fifth lines. In Su Shi's composition, every third line describes the auspicious environment of the villa. The last two lines, notably, encode the gist of the message of each stanza.

In the first stanza, the ending couplet depicts a 'master' in contented sleep. He is well respected, as the narrative voice urges the temple bell-ringer not to disturb him by announcing the time. This image models itself on the iconic, timeless sleep of Chen Tuan 陳摶 (?-989), the Daoist master at Paramount Hua, who sometimes slept for months, leaving the emperors' envoy to wait in vain. ${ }^{107}$ His negligence of time suggests his externality and, by the same token, he became an advisor to the throne without subjecting himself to the imperial power. Su Shi imagines himself another Chen Tuan, as in the second stanza the local magistrate comes to ask for the Way of governance. Stanzas three to five depict a series of planting and building projects. His undertakings are encoded. The orange tree is alternatively called 'wooden slave' (munu 木奴). Li Heng 李衡 (third century), Magistrate of Danyang 丹陽 (in modern Jiangsu Province), left a thousand 'wooden slaves' to his sons to provide for their livelihood and ensure their economic independence. ${ }^{108} \mathrm{Su}$ Shi's planting of two orange trees signifies a similar wish for material independence from official salary or charity. His next step is to build a fishing terrace. Holding a fishing pole symbolises both longing for and resistance to imperial power. Historical examples include many would-be advisors to the throne. ${ }^{109}$ The angling fisherman does not seek to catch the 'fish', namely imperial recognition, but instead waits patiently for it to come to the 'bait', namely his virtue and infinite potential in governance. If the fish does not come, $\mathrm{Su}$, the self-sufficient fisherman, is fine with that too. He will build a Terrace of Gazing at the Immortals and will then depart with the retinue of clouds into the empty mountains.

In the last stanza, the poet, while playing the role of an amiable neighbour, watches himself changing into a "feathered one" on a long ladder of life (sym-

107 Chen Tuan's legendary sleep was a popular theme among Su Shi's contemporaries. The first extensive account appeared in Zhang Fangping 張方平 (1007-1091), "Huashan chongxiu Yuntaiguan ji” 華山重修雲臺觀記, Lequan ji 樂全集, $S K Q S$, 1104·33.11-5.

108 As recorded in Xi Zaochi's 習錐齒Xiangyang ji 衰陽記, quoted by Pei Songzhi 裴松之, in Chen Shou 陳壽, Sanguo zhi 三國志 (Beijing: Zhonghua shuju, 1959), 48.1156-7.

109 Famous examples include Lü Shang 吕尚 (eleventh century BCE), the founding minister of the Zhou Dynasty (see “Qi Taigong shijia” 齊太公世家, Sima Qian, Shiji, 32.1477-8), and Yan Guang 嚴光 (first century CE), recluse and friend of the first Eastern Han emperor (see “Yimin liezhuan” 逸民列傳, Fan Ye 范曄, Houhanshu 後漢書 [Beijing: Zhonghua shuju, 1965], 2763-4). 
bolised by the cinnabar), stretching into the night sky. The spectator is none other than a wolfberry-dog. ${ }^{110}$ This miraculous dog is itself transformed from the root of a thousand-year-old wolfberry. It lives in the Cave of Vermilion Light, ${ }^{111}$ not far from Su's villa, and now, in the small hours of the day, sees his silent transformation.

[3] I pray, after the installation of beams, that crops shall grow every year on the mountains and no hurricane shall rise above the ocean. The air shall be dry and clear; my family healthy; and there will be no need for Dr. Chen's drug. The harvest shall be big; the rice be cheap; and I can buy on credit Aunty Lin's wine. Whoever associates with me shall increase fortune and longevity.

伏願上梁之後, 山有宿麥, 海無風風。氣爽人安, 陳公之藥不 散；年豐米賤，林婆之酒可賖。凡我往還，同增福壽。

At the end of the liturgical text, Su again plays the good farmer-recluse. He has no other wish than the health of his family and the fortune of his associates. What is left unsaid is that he has always been a curse in others' lives - his longterm companion, Zhaoyun 朝雲 (1062-1095), has just died of miasma and his family and friends are still victims of his downfall. Now, he wishes no more suffering, so that he can take leave with peace of mind.

In this light-hearted text, the poet envisions himself enjoying a certain 'alterity', displaying multiple identities in varying contexts. Among the villagers, he is an amiable neighbour. With the local magistrates, he is a high-minded counsellor in hiding. Yet, at the end of the day, he is the immortal climbing a cinnabar ladder into another realm of existence.

The construction of the villa at White Crane Peak culminated Su's transformation of his identity into a Daoist alchemist and recluse. Only two months later, however, Su was further banished to Hainan. His reading of destiny proved wrong.

110 See ch. 4, fn. 122.

111 The Cave of Vermilion Light, said to be a grotto heaven, is located behind Chongxu Temple 沖虛觀 where Ge Hong once lived. Allegedly, the roots of ancient wolfberry trees growing in the hidden depths of this cave had changed into miraculous canines that sometimes barked at night. See Su Shi, “Ciyun Zhengfu you Baishuishan” 次韻正輔同游 白水山, sssJ, 39.2148-50. 


\section{Retreat from Nature}

If the legend was true, Su Shi's jovial couplet, "Men all say - the master sleeps soundly in the spring; strike lightly the fifth-watch, ringer of the temple bell", stirred great ire in the heart of his learned enemy, Chancellor Zhang Dun. To deprive Su of such ease, Zhang banished Su even farther to Danzhou. It was presumably a diabolic jeu de mots: the character dan 儋 shares the same phonetic with zhan 瞻, as in Su Shi's polite name Zizhan 子瞻. Legend further has it that Zhang Dun was exacting revenge for Su Shi's ridiculing of his mentor Wang Anshi's etymological interpretation of the classics. ${ }^{112}$

This story is fantastical, but not implausible. For men who lived in texts, life was comprehensible only in reference. After all, the same could be said of $\mathrm{Su}$ Shi: he perceived Mt Luofu as his destined locus of transcendence only because of the precedence of Ge Hong, author of Baopuzi, a work itself deeply embedded in a shared textual tradition. Mesmerised by the textual references encoded in the name Luofu, Su Shi derived a reading of his fate - a reading that proved wrong because of Zhang Dun's reading of a text which encoded Su's reading of fate.

His forced departure from Huizhou seemed to be disillusioning. Su Shi realised that he was not predestined to die - or 'undie' - on White Crane Peak after all. Even if he did not lose faith in the Daoist art per se, he no longer believed in his own chance of transcendence, as revealed in his Hainan poems. ${ }^{113}$ His change of mind is summarily represented in the "Rhapsody on the Milky Spring of the Tianqing Temple” (Tianqingguan ruquan fu 天慶觀乳泉賦), ${ }^{114}$ written in 1098 and held by himself to be his best composition at Hainan. ${ }^{115}$ In this text, he first expatiates on a general theory of water as the source of vitality. According to him, all water could be dichotomised into 'sweet' (gan 甘) and 'salty' (xian 鹷), each associated respectively with vitality and death. Corporeal

112 See Zeng Jili, Tingzhai shihua, 66-7. This story is recorded in slightly different versions in Lu You, Laoxuean biji, 4.50, as well as in Luo Dajing 羅大經, Helin yulu 鶴林玉露 (Beijing: Zhonghua shuju, 1983), bingbian 丙編, 5·315, two usually reliable works. Even if there was not necessarily an actual plot, Zhang Dun's desire to see Su Shi's death was perhaps real enough. As a poem by Huang Tingjian states, "When Zizhan was banished to the South of the Dayu Ridge,/ then Chancellor wanted to see him dead” 子瞻謫嶺南，時宰欲殺之; see “Ba Zizhan “He Tao shi”” 跋子瞻和陶詩, Huang Tingjian quanji, 17.604.

113 Ronald Egan has translated some of them: see Egan, Word, Image, and Deed, 244-5. Yet, without seeing the transition in Su Shi's belief, Egan wrongly understands Su Shi's selfdoubt as his doubt of the pursuit of longevity (especially Ge Hong's pursuit) per se.

114 Su Shi, "Tianqingguan ruquan fu", sswJ, 1.15-6.

115 See Fei Gun, Liangxi manzhi, 4.7 . 
liquids, including sweat, tears, urine and blood, are all salty; they represent material forms of the death essence which tends to depart the human body. Only the "true liquid of the Blossom Pond", namely, saliva, is sweet and is the original drug of immortality. The cosmic sweet water circulates in the forms of rain, dew, frost and snow, and accumulates in rivers, lakes, wells and springs. In this perpetual cycle of transformation, water is eternal and inexhaustible, and so is vitality. Seawater and salty springs, on the other hand, are the accumulated death essence of the cosmos; these kill and do not nourish life. After relating this general theory, Su Shi described his nocturnal excursion to a sweet spring in a Daoist temple - the source of immortal life.

Since I was banished to live in Dan'er, ${ }^{116}$ I divined a construction spot to the south of the city wall, next to the temple of the God of Fate. All the local wells are salty, except one spring, sweet like ale and milk surging from within the temple. It provides for my cooking, drinking and making of wine and tea. How abundant and inexhaustible! Once I rose in the middle of the night, took a drinking jar and went east. Only the setting moon followed me - no human companions.

The water-fetcher did not stir and the cosmic air of the night just began to retreat. The spring clanged like jade pendants falling into a valley. The jade pond, scintillating, gave birth to rich foams. ${ }^{117}$ I gulped thrice and returned immediately, afraid to be chided by guardian gods. I shall abjure the five flavours ${ }^{118}$ to decline the six kinds of dust. ${ }^{119}$ When I realise the one single truth, I shall shed all the hundred misdeeds. I believe in an elixir that leads to immortality. But nothing presides deep within me, so

116 Aka. Danzhou; a name that refers to its ancient people's purported ethnographic feature of having huge ear lobes.

117 “In the jade pond, pure water gives birth to rich foam"玉池清水上生肥. The “jade pond" refers to the mouth; "pure water" refers to pure saliva. The practitioner should use his tongue to stir saliva pooled below the tongue until foam is formed, then swallow the foam. See Shangqing huangting neijing jing, Zhang Junfang, Yunji qiqian, ch. 29, 285; cf. ibid., 272.

118 Referring to food which tastes sour, bitter, sweet, spicy or salty. See Zhonghua daojiao dacidian 中華道教大辭典, ed. Hu Fuchen 胡孚琛 (Beijing: Zhongguo shehuikexue chubanshe, 1995), 472.

119 Referring to six kinds of worldly desires which cloud one's authentic nature. The concrete numeration differs. One definition suggests that these are the dusted six 'roots', i.e. eyes, ears, nose, tongue, body and mind. Another definition lists wealth, lust, fame, gluttony, sleep and laxity. A third theory lists lust, music, fragrance, taste, touch and dharma. See Hu Fuchen, Zhonghua daojiao dacidian, 472. 
what can I depend upon? Alas, Master Scarlet Pine, Prince Qiao, where art thou? Let my imagination, let my fantasy, to capture thee!

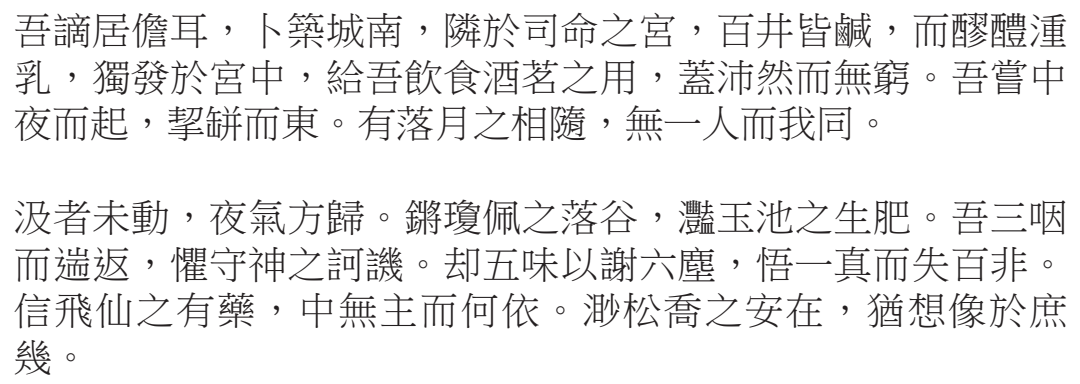

At daytime, this spring displays an appearance of deceptive normalcy: it supplies the local households with their daily water. Yet, this sole fresh-water source is located nowhere else than in the palace of the God of Fate. The deeply meaningful location associates the spring to the realm of fate and transcendence.

The poet does not explain what made him restless at midnight and drove him on this nocturnal excursion. He might have been either unable to sleep or practising meditation. In any case, he seems to be possessed by mystic inspiration. He finds the spring refreshing; the spring itself at the cosmic moment of night changing slowly into day, a moment symbolised and strengthened by the change of rhyme (marked by the paragraph break in my translation). He calls it a "jade pond", a physiological alchemical term which relates the spring water to saliva, a source of vitality. But the devoted adept feels uneasy in the suspected presence of the "guardian gods". He takes three - a symbolic number for triadic unity - gulps of water and immediately returns, as if having violated a territory he had no right to enter. Despite his belief in the drug of immortality, he wonders if he is ready to take it. To receive the drug, he needs something "presiding" ( $z h u$ 主) inside. This presiding force might refer to a spiritual embryo (lingtai 靈胎) formed through physiological alchemy. Transcendence is achieved only when an "embryo of the subtle and immortal body" is formed to replace the adept's gross body. ${ }^{120}$ Without this fully formed embryo, the adept can only fantasise about the realm of divinity.

The structure of adventure into, and immediate retreat from, a transcendental realm also appears in the "Latter Rhapsody on the Red Cliff" (Hou Chibi fu 後赤壁賦), written in the late fall of 1082, during his exile in Huangzhou. ${ }^{121}$ In the widely celebrated "Former Rhapsody on the Red Cliff" (Qian Chibi fu 前 
赤壁賦), composed three months earlier, Su Shi declares that he shall transcend the fear of mortality by entrusting himself to the cosmic cycle of change, since the distinction between the eternity of the universe and the transience of individual life is illusory, relative to perspective. ${ }^{122}$ However, in the less-acclaimed "Latter Rhapsody", which also depicts a nocturnal boat excursion to the Red Cliff with two unnamed guests, Su Shi is driven by restlessness. He climbs the cliff alone, ventures into the realm of powerful creatures and heaves a long whistle at the top of the cliff. Nature responds with resounding echoes and surging wind and waves. Feeling a sudden chill, the poet retreats in fear. When he is back in the boat, a lone crane soars over his head and emits a loud and long shriek. That night, Su Shi dreams of a Daoist (who refuses to reveal his name) in a feathered robe, asking him, "Was the excursion to the Red Cliff delightful?". In response to Su Shi's question of whether he was the crane, the Daoist smiles and disappears, leaving the poet to wake with a pounding heart. ${ }^{123}$

The tone of optimistic abandon in the "Former Rhapsody" disappears from the "Latter Rhapsody". The poet's enchanted climb sets him apart from his two guests, who are incapable of leaving the security of the boat - an artificial haven. He sees tigers, leopards, dragons and falcons in their true forms at night, dangerous but indifferent to his existence. He even peeps into the hidden palace of Pingyi 馮夷, the River God. Yet, in the neighbourhood of divinity, the poet only feels his own alienness - his unbelonging. He retreats abruptly with awe and fear. The crane, incarnated as the feathered Daoist in his dream, is a signal sent by this transcendental realm. But its intention is ambivalent. The long shriek may be either to beckon or to warn. And, if the poet in the "Latter Rhapsody" still cherishes the hope of having been beckoned by the transcendental, the poet in the Tianqing Temple has now entirely lost such hope. His fetching of the primordial water appears to him a hasty theft, one that risks the chiding of guardian gods.

As the last line of the "Rhapsody on the Milky Spring" suggests, he may not achieve the ultimate freedom, represented by immortals like Scarlet Pine or Prince Qiao. Nevertheless, his freedom is secured in creative imagination, which literally takes flight in the form of spiritual roaming. He retreats, therefore, from nature into an inner cosmos - even though this freedom is conditioned by his physicality. In a cryptic poem written one restless night, Su Shi tries to pacify his anxiety over mortality:

故山不可到 The hometown mountains cannot be reached 飛夢隔五嶺型y flying dream is obstructed by the Five Ranges.

122 Su Shi, “Qian Chibi fu” 前赤壁賦, sswJ, 1.6.

123 Su Shi, “Hou Chibi fu” 後赤壁賦, sswJ, 1.8. 


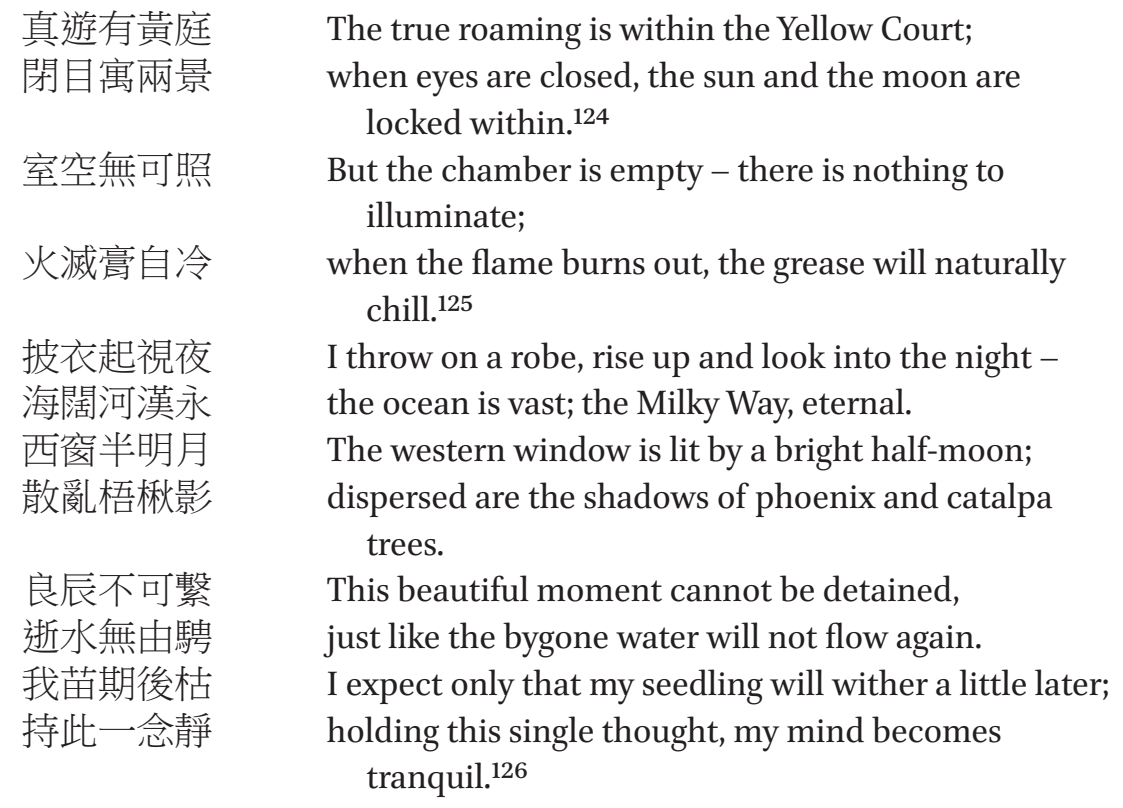

This poem begins with images of distance and obstruction. His dream is concretised as a flying bird, but its wings are not powerful enough to flap across the mountain ranges separating the southern regions from the central plains. When physical 'return' cannot be accomplished, the poet resorts instead to pure meditation within the "Yellow Court" as a form of true roaming. Once in this inner cosmos, however, Su realises that his inner chamber is empty - perhaps suggesting again that his 'spiritual embryo' has not been formed as yet. He is running out of time: his fire of life is dying and his flesh chilling. His fear of mortality cannot be dissuaded by philosophy, and the poet is disquieted. The vast ocean and eternal Milky Way signify constancy, but the sinking half-moon and dispersed shadows symbolise his waning hours and draining vitality. The beauty of the present moment is incessantly fading into the past. After denouncing the power of mental reality, Su Shi, in the small hours of the night, concludes that he should try to nourish his physical wellbeing, without which nothing can be helped. The penultimate line refers to the aforementioned

124 Namely, the two eyes. In Daoist meditation practice, when the eyes (the left eye is the sun, the right eye is the moon) are closed, the adept shall imagine the sun and the moon shining through his "inner landscape" (neijing 內景), that is, his internal organs. See Shangqing huangting neijing jing, in Zhang Junfang, Yunji qiqian, 200-1. For a detailed description of this inner landscape, see Schipper, Taoist Body, 105-08. 
'crop' analogy in Ji Kang's treatise. Though death is the ultimate call, it is a moral command for man to prolong life as much as he can, just like a farmer must keep tending his crops despite the cosmic drought. When the crop finally withers, at least the farmer feels at peace.

\section{Active Immersion in Transience}

Now that the aged poet was convinced of his mortality, the existential angst could only be alleviated by living in the constant transience. Su Shi in Hainan suffered from deprivation and ill health. The past could not be saved; destiny could not be calculated. The spiritual spontaneity of living in transience was, for him, not a philosophical catchphrase but a survival strategy.

This sentiment permeates many of Su Shi's writings at Hainan and is best articulated in a triad of poems matching Tao Qian's allegorical "Form, Reflection and Spirit” (Xing ying shen 形影神), a set of three poems which imagine the versified dialogue among the three aspects of human existence. In Tao's poems, Form laments its mortality. Reflection, pointing out that the wish for immortality is vain given the extreme challenge of the task, proposes that the only thing remaining after death is one's good deeds. Each speech ends with the gesture of offering a toast with a cup of wine. Spirit offers to appease their anxiety by arguing that not even good deeds matter. Everything is over when one dies, but there shall be no fear - since this is the natural course of things. ${ }^{127}$ Su Shi admired Tao's philosophical equanimity, despite his own ambivalence. In his matching poems, he offered three sophisticated approaches to the question of death. Form represents the physical aspect of human existence. From its point of view, the greatest fear in life is the unknown, which often assumes a metaphysical dimension. Death is the ultimate unknown. The only certainty is the precise correspondence between physical existence and its own "reflection". ${ }^{28}$ Reflection represents the world's perception of an individual's existence. Any action has its consequence on one's perceived image, which, like a reflection in a mirror, does not vanish even when the mirror is smashed.

127 Tao Qian, “Xing ying shen” 形影神, тYM, 2.67. David Hawkes interpreted these three poems to represent respectively the perspective of religious Daoism, Confucianism and Zhuangzian Daoism (or Heavenly Teacher sect); see David Hawkes, The Poetry of T'ao Ch'ien (Oxford: Clarendon Press, 1970), 44-5. He translated the title as "Substance, Shadow and Spirit". I choose to translate it as "Form, Reflection and Spirit", since this set of terms works better for Su Shi's argument.

Su Shi, “He Tao 'Xing zeng ying”” 和陶形贈影, sssJ, 42.2306. 
Its response raises the doctrine of non-duality. It suggests that active cognitive capacity (being awake) or the lack thereof (being drunk) does not make a difference in a dream world - a world of illusions. ${ }^{129}$ At last, the Spirit comes to offer its solution: ${ }^{130}$

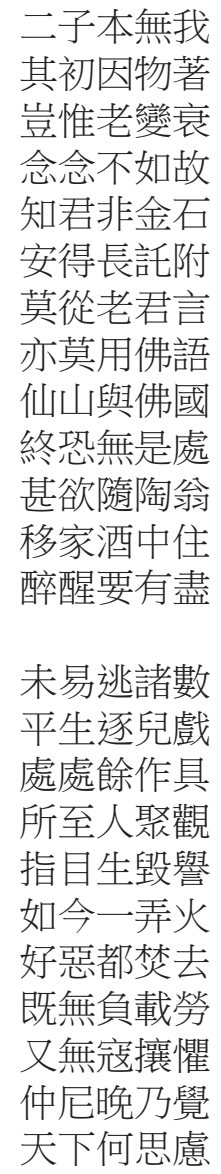

The two gentlemen had no ultimate selves, but assumed their forms by adhering to things. Is it only because of the decrepitude of age, that with every single thought your state deteriorates? Knowing that you are unlike metal or stone, how can I consign myself long to you? Please don't follow the words of Lord Lao; nor use the Buddha's talk. The immortals' mountain or the Buddha's Land, for me there is none, I fear! My heart desires to follow the old man Tao move the household to the land of wine! But being drunken or awake, either state comes to an end; there is no easy escape from one's fate. All my life is like chasing a child's play, leaving playthings wherever I stay. Everywhere I go, people gather to watch me; pointing or eyeing they blame or praise me. Now in a single feat of fire, fondness or disgust are both burnt. There remains no more ado to load or carry, nor any fear of inroad or robbery. Confucius realised this point only late what thought or worry is there in All-under-Heaven? ${ }^{131}$

Ironically, Spirit, as the thinking faculty of man, concludes that its own abdication alone promises happiness. It sees no material vehicle as permanent. Even the Reflection, as trace of one's existence in the world, relies on material

\footnotetext{
129 Su Shi, “He Tao 'Ying da xing”” 和陶影答形, sssJ, 42.2307.

130 Su Shi, “He Tao 'Shen shi”" 和陶神釋, sssJ, 42.2307-8. Ronald Egan has offered a partial translation of the poem: Egan, Word, Image, and Deed, 245 .

131 In the "Xicixia” 繫辭下 chapter in the Book of Changes, the Master says, "What thought or worry is there in All-under-Heaven?” 天下何思何慮. See Zhouyi zhengyi, 8.75, ssJzs, 87.
} 
vehicles for its perpetuation. The only way to preserve Spirit is for it to stand all alone. Both Daoism and Buddhism promise escape from decay. But Su Shi admits misgivings about both choices. Unable to make a commitment, he opts to forget both and escape to an alternative destination - the land of wine where Tao Qian sojourned. Yet, being drunk is not forever. Ultimately man must face his fate, soberly and alone. In the looming shadow of death, he regrets the futility of his engagements with the world, his traces littered around like toys. Praise or blame depends on others, not on him. In the Book of Changes, an aged Confucius comes to see a world as a harmonious given. Su Shi, also aged and commenting upon the Changes, likely abjures any further thought or worry.

The active immersion in transience is an insight boasted in many of Su Shi's Hainan poems, and is often admired by commentators as representing his ultimate spiritual achievement. It finds expression in, for instance, a triad of poems titled "Three Comforts in the Life of Exile" (Zheju sanshi 謫居三適), ${ }^{132}$ celebrating respectively combing one's hair in the morning wind, napping below the window at noon, and bathing one's feet warm at night. All these comforts have a tactile quality. They are quiet, physical pleasures that will only permeate a peaceful body. With these poems of ostensible ease, Su Shi rhetorically transformed a life of hardship into a flow of enjoyable moments.

By means of mental exercise, a strict regimen and physiological alchemical practices, Su lived to see the general amnesty in 1100, which was announced to celebrate Huizong's 徽宗 (1082-1135, $r$. 1100-1126) enthronement. Once across the strait, Su Shi wrote many social poems for the Buddhist monks he encountered on his northbound return, in which he expressed insights gained from his experiences of exile. In a poem to a Chan master in Qianzhou 虔州 (now Ganzhou, Jiangxi Province), he expatiates on his understanding of time:

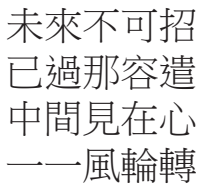

What is yet to come cannot be summoned; what has passed can no longer be dispatched. Midway is the mind of transient presence, which turns and turns like a wheel in the wind. ${ }^{133}$

The active immersion in transience keeps the mind constantly engaged midway between a bygone past and an unforeseeable future. This view is indebted to the Tiantai Sect's doctrine of the "Threefold Truth", as discussed in Chapter One. This heart that settles in the midway - the truth of conventional existence - responds to every puff of wind with readiness and alertness. One's

132 Su Shi, "Zheju sanshi sanshou", sssJ, 41.2285-7.

133 Su Shi, “Mingri Nanchan heshi budao [...]” 明日南禪和詩不到 [...], sssJ, 45.2436. 
physical body is thus transported into utter spontaneity. Once arrived at this state of being, one shall actively maintain it to the end of one's life, until death snatches it all.

\section{Coda}

Death indeed caught Su Shi by surprise - he fell ill with malaria soon after he arrived in Changzhou 常州 (in modern Jiangsu Province), where he planned to retire. Ironically, his philosophical 'return' to settle in the southern territories prolonged his life, but his physical return to the central plains brought death. A poem, said to have been written on his deathbed, declares:

大患緣有身 無身則無疾 平生笑羅什 神呪真浪出
The greatest suffering comes from having the body; without the body, there is no more disease.

All my life I have been laughing at Kumārajīva whose magic spells [on his deathbed] were truly a waste. $^{134}$

The official biography of Kumārajīva, the Kuchean monk and great translator, relates that he tried to deter death by incanting magic spells. ${ }^{135}$ Despite Su Shi's avid practice of Daoist alchemy, Kumārajīva's attempt struck him as laughable, since an enlightened being should eliminate even the distinction between life and death. It seems that, for him, there was a fine line between cultivating the physical being with care, and fending off death by magic. To borrow Ji Kang's crop analogy, the former is to water the seedling, so that it may fulfil its natural life span; the latter is to artificially revive the seedling when its number is already up. A man subscribing to the doctrine of provisional spontaneity must resign when his fate is finally known.

134 Su Shi, "Da Jingshan Lin zhanglao" 答徑山琳長老, sssJ, 45.2459.

135 See Kumārajīva's biography in “Yishuzhuan” 藝術傳, Fang Xuanling, Jinshu, 95.2502. Authentic or not, this story recounts the close affinity of early Buddhism with magic, when high-ranking monks, especially those of foreign origin, were often magicians and miracle workers. 


\section{Towards a Conclusion}

In this book, the concept of 'spontaneity' is defined negatively and dialectically. Absolute spontaneity exists only as something lost or impossible. Paradoxically, when one strives to achieve the impossible while recognising one's limits, a second kind of spontaneity - provisional and conditioned - may be actualised.

Artistic and ethical spontaneity is a universal ideal because of the innate tendency of thoughts to reach beyond the sheer materiality of existence. The ideal of spontaneity thus possesses utopian characteristics of negation and discontent. The ultimate negation, however, directs itself towards thinking per $s e$. Such a higher form of reflection reconfirms materiality or the absence of human agency as the utopia - a utopia in which man necessarily has no position. It is like Eden, where proto-humans wandered in animal form, without self-consciousness. Man cannot live in Eden but constantly tries to return there, where he will be relieved of the burden of self-knowledge. The Way is simultaneously a goal and a process. On the Way towards absolute spontaneity, one partakes of the bliss when one recognises the non-existence of the final destination and knows that the full truth is in the process of treading the path.

This is the source of Su Shi's 'gay genius', a benign spirit that was once amicable and uplifting. Despite his lofty aspirations - to become a divine artist who creates works as Heaven creates things, or to become an immortal who roams in utter freedom, riding cosmic forces - he also laughed at his limits. He knew that his resignation was necessary, as he was bound by external forces human nature, state authority, destiny and death - and revolt would be in vain. If his insight brought him close to the modern existentialists, his genuine optimism set him apart. Instead of seeing the world as absurd, he saw it, together with its immense time and space, as endless opportunities to enrich himself towards completion, however unattainable the goal was. As a result, his 'spontaneity' embraced its opposites, including mediacy, materiality, cultural paradigms and rituality. In a jovial twist, it was also employed as a rhetorical device to achieve various ends, such as self-persuasion, self-justification, to write occasional poetry for friends or to simply excuse his weaknesses. Yet, the weaknesses that he chose to expose in his poetry also endeared him to later readers, encouraging them to imagine that Su's poetry was a faithful mirror that reflected the author's true nature. My reading, in a certain sense, continues the myth, despite my wish to break away from it. The mirror of Su Shi reflects my own face as a modern and transcultural reader. 
The continuing practice of reading into the author is not a bad thing. I am thinking of Professor Morris Zapp, the fictitious English literature professor in David Lodge's Small World trilogy, who wanted to write such a comprehensive work on Jane Austen that he would put an end to the field, once and for all. Fortunately, students of Chinese literature know better. Ever since the twelfth century, there have been many attempts at reading Su Shi that faithfully render the 'true' author; yet, the reading goes on, making his works a 'classic' in the sense of something that is 'forever inexhaustible' in interpretation (Goethe), or something that "has never finished saying what it has to say" (Calvino). ${ }^{1}$ Each generation of readers finds its own new way to approach Su Shi, who has been transformed into the Mt Lu that he describes in a poem:

橫看成嶺側成峰 Seen from the front it is a long range; from the side, a lofty peak;

遠近高低各不同 from afar, nearby, high or low, its looks are in constant change.

不識盧山真面目 I do not know the true appearance of Mount Lu, 只緣身在此山中 because my body stands in the middle of this mountain. ${ }^{2}$

If the reception history of Su Shi's works has become the Mt Lu that he describes, my own reading, as part of this history, contributes one more modern sketch of the mountain.

This book is a personal journey. I read Su's poems as a child, reread them as a college student, and truly began to engage with them when I was in Princeton - an ocean and a continent away from home. His poem on the Cold Food Festival in Huangzhou always takes me back to my first few days there.

$\begin{array}{ll}\text { 年年欲惜春 } & \text { Year after year I tried to detain the spring; } \\ \text { 春去不容惜 } & \text { but the spring departed without being detained. } \\ \text { 今年又苦雨 } & \text { This year again the bitter rain has been falling - } \\ \text { 兩月秋蕭瑟 } & \text { in two months of autumn desolation. }{ }^{3}\end{array}$

The semester had not started, and my unknown roommate had not yet arrived. I was alone in a barracks-style apartment, with no furniture (aside from a mattress and a laptop). Far from the downtown, I had no telephone or trans-

\footnotetext{
1 I thank Martin Kern for sending me these two quotes.

2 Su Shi, “Ti Xilin bi” 題西林壁, sssJ, 23.1219.

3 Su Shi, “Huangzhou yu ershou” 黃州雨二首, $s s s J, 21.1112-3$.
} 
portation, and there was not a soul to talk to. I felt sealed off from the world by the East Coast September rain. I now wonder whether this experience had something to do with my later choice of writing a dissertation on Su Shi, and particularly about 'being spontaneous'. How was I unlike Lin Yutang, who packed Su Shi's poetry anthology in his suitcase to America, disregarding the economics of luggage space? Seemingly, for both Lin and me, Su Shi speaks intimately about living in the diaspora.

But this personal journey does not end with a dissertation or a book. In the summer of 2013, I finally went to Meishan, a misty town in the Sichuan Basin where Mt Emei stands at the southern rim of the sky. The Three Sus Shrine (San Suci 三蘇祠) daily welcomes a steady flow of tourists from all over China. The two ancient ginkgo trees standing inside of the gate were allegedly planted by Shi and Che when they were naughty prodigies. The trees survived centuries, as well as a recent earthquake which had wrecked parts of the garden. The damp garden, soaked in basin heat, was littered with references to its erstwhile sons' conquests and downfall in a vast world that most locals had never seen. I was among a group of Su Shi specialists. Every tiny detail triggered their inexhaustible repertoire of Su Shi trivia. We readily recited lines from his poems and knew exactly what each other was talking about. In the flow of our voices, this wretched garden was transformed into a miniature cosmos, filled with history, geography, intersubjective resonances and reenacted cultural memories. I suddenly realised that Su Shi was living in us and through us. Over the years, his texts have been the source of such inspiring dialogues. I hereby pass on a story of how I reached through those dialogues, towards myself. 


\section{Bibliography}

\section{Premodern Chinese Sources}

Ban Gu 班固. Hanshu 漢書. Beijing: Zhonghua shuju, 1964.

Bo Juyi 白居易. Bo Juyi ji 白居易集. Beijing: Zhonghua shuju, 1979.

Cao Xu 曹旭. Shipin jizhu 詩品集注. Shanghai: Shanghai guji chubanshe, 1994.

Chao Buzhi 晁補之. Jilei ji 雞肋集. SKQS, vol. 1118.

Chen Jingyi 陳景沂. Quan fang bei zu 全芳備祖. Taipei: Shangwu yinshuguan, 1974.

Chen Menglei 陳夢雷, editor. Gujin tushu jicheng 古今圖書集成. Taipei: Wenxing shudian, 1964.

Chen Qiaoyi 陳橋驛. Shuijingzhu jiaozheng 水經注校證. Beijing: Zhonghua shuju, 2007.

Chen Shou 陳壽. Sanguo zhi 三國志, commentary by Pei Songzhi 裴松之. Beijing: Zhonghua shuju, 1959.

Cheng Hao 程影 and Cheng Yi 程頣. Er Cheng ji 二程集. Beijing: Zhonghua shuju, 1981.

Dai Mingyang 戴明揚. Ji Kang ji jiaozhu 嵇康集校注. Beijing: Renmin wenxue chubanshe, 1962.

Duan Chengshi 段成式. Youyang za zu 酉陽襍众. Beijing: Zhonghua shuju, 1981.

Duan Yucai 段玉裁. Shuowen jiezi zhu 說文解字注. Shanghai: Shanghai guji, 1981.

Fan Chengda 范成大. Mei pu 梅譜. In Fan Chengda biji liuzhong 范成大筆記六種. Beijing: Zhonghua shuju, 2002.

Fan Ye 范曄. Houhanshu 後漢書. Beijing: Zhonghua shuju, 1965 .

Fang Xuanling 房玄齡. Jinshu 晉書. Beijing: Zhonghua shuju, 1974.

Fei Gun 費衰. Liangximanzhi 梁溪漫志. Shanghai: Shanghai shudian, 1999.

Guo Qingfan 郭慶藩. Zhuangzi ji shi 莊子集釋. Beijing: Zhonghua shuju, 1961.

He Wenhuan 何文煥, editor. Lidai shihua 歷代詩話. Beijing: Zhonghua shuju, 1981.

He Yuan 何赺. Chunzhu jiwen 春渚紀聞. Beijing: Zhonghua shuju, 1983.

Hong Mai 洪邁. Rongzhai suibi 容齋隨筆. Beijing: Zhonghua shuju, 2005.

Hong Xingzu 洪興祖. Chuci buzhu 楚辭補注. Beijing: Zhonghua shuju, 1983.

Hu Daojing 胡道靜. Mengxi bitan jiaozheng 夢溪筆談校證. Shanghai: Shanghai chubangongsi, 1956 .

Hu Zhiji 胡之驥. Jiang Wentong ji huizhu 江文通集彙註. Beijing: Zhonghua shuju, 1984.

Hu Zi 胡仔. Tiaoxiyuyin conghua 莒溪漁隱叢話. Beijing: Renminwenxue chubanshe, 1962.

Huangfu Mi 皇甫䍀. Gaoshizhuan 高士傳. Congshu jicheng edition. Shanghai: Shangwu yinshuguan, 1937 .

Huang Hui 黃暉. Lunheng jiaoshi 論衡校釋. Beijing: Zhonghua shuju, 1990. 
Huang Jie 黃節. Xie Kangle shizhu 謝康樂詩注. No publishing details, 1925.

—_. Bao Canjun shizhu 鮑參軍詩注. Beijing: Renmin wenxue chubanshe, 1957.

Huang Tingjian 黃庭堅.Huang Tingjian quanji 黃庭堅全集. Chengdu:Sichuan daxue chubanshe, 2001.

Huang Zongxi 黃宗羲. Songyuan xuean 宋元學案. In Huang Zongxi quanji 黃宗羲全 集, vol. 4. Hangzhou: Zhejiang guji chubanshe, 2005.

Huanzhen xiansheng 幻真先生. Taixijing zhu 胎息經註. In Daoxue jinghua 道學精 華. Hong Kong: Shanchang shuju, $195^{\circ}$.

Huihong 惠洪. Lengzhaiyehua 冷齋夜話. Beijing: Zhonghua shuju, 1988.

Ji Han 嵇含. Nanfang caomu zhuang 南方草木狀. In Hanwei liuchao biji xiaoshuo daguan 漢魏六朝筆記小說大觀. Shanghai: Shanghai guji chubanshe, 1999.

Jiao Xun 焦循. Mengzi zhengyi 孟子正義. Beijing: Zhonghua shuju, 1987.

Li Bo 李白. Li Taibai quanji 李太白全集. Beijing: Zhonghua shuju, 1977.

Li Fang 李昉, editor. Taiping yulan 太平御覽. $s K Q S$, vols.893-901.

—, editor. Taiping guangji 太平廣記. $s K Q s$, vols.1043-6.

Li Shizhen 李時珍. Bencao gangmu 本草綱目. Hefei: Huangshan shushe, 1992.

Li Tao 李壽. Xu Zizhi tongjian changbian 續資治通鑒長編. Beijing: Zhonghua shuju, 2004.

Li Zhi 李廌. Shiyou tanji 師友談記. Beijing: Zhonghua shuju, 2002.

Lingxuan 伶玄. Zhao Feiyan waizhuan 趙飛燕外傳. In Biji xiaoshuo daguan 筆記小 說大觀. Taipei: Xinxing shuju, 1974.

Liu Baonan 劉寶楠. Lunyu zhengyi 論語正義. Beijing: Zhonghua shuju, 1990.

Liu Wendian 劉文典. Huainan honglie jijie 淮南鴻烈集解. Beijing: Zhonghua shuju, 1989.

Liu Xiang 劉向. Lienüzhuan huibian 列女傳彙編. Beijing: Beijing tushuguan, 2007.

Liu Zongyuan 柳宗元. Liu Hedong ji 柳河東集. Shanghai:Shanghai renmin chubanshe, 1974.

Lu Ji 陸機. Lu Jiji 陸機集. Beijing: Zhonghua shuju, 1982.

Lu Qinli 逯欽立. Xianqin Han Wei Jin Nanbeichao shi 先秦漢魏晉南北朝詩. Beijing: Zhonghua shuju, 1983.

Lu You 陸遊. Laoxuean biji 老學庵筆記. Beijing: Zhonghua shuju, 1979.

Luo Dajing 羅大經. Helin yulu 鶴林玉露. Beijing: Zhonghua shuju, 1983.

Ma Qichang 馬其昶. Han Changliwenjijiaozhu 韓昌黎文集校注. Shanghai: Shanghai guji chubanshe, 1986.

Ma Ruichen 馬瑞辰. Maoshi zhuanjian tongshi 毛詩傳箋通釋. Beijing: Zhonghua shuju, 1989.

Meng Naichang 孟乃昌 and Meng Qingxuan 孟慶軒, editors. Wangu danjing wang: Zhouyi cantongqi sanshisijia zhushijicui 萬古丹經王：《周易參同契》三十四 家註釋集萃. Beijing: Huaxia chubanshe, 1993. 
Ouyang Xiu 歐陽修. Ouyang Xiu quanji 歐陽修全集. Beijing: Zhonghua shuju, 2001. Peng Jiuwan 朋九萬. Dongpo Wutai shian 東坡烏臺詩案. Taipei: Yiwen yinshuguan, 1968.

Puji 普濟. Wudeng huiyuan 五燈會元. Taipei: Guangwen shuju, 1971.

Qian Bocheng 錢伯城. Yuan Hongdao ji jianjiao 袁宏道集箋校. Shanghai: Shanghai guji chubanshe, 2008.

Qiu Zhao'ao 仇兆鰲. Du shi xiang zhu 杜詩詳注. Beijing: Zhonghua shuju, 1979. Ruan Yuan 阮元. Shisanjing zhushu 十三經注疏. Beijing: Zhonghua shuju, 1980.

—.Xingming guxun 性命古訓 (Yanjingshi ji 擘經室集, vol. 1, juan 10), printed in Zhongguo zhexue fanchou congkan 中國哲學範疇叢刊 (第一函). Beijing: Beijing tushuguan chubanshe, 1997.

Ruan Yue 阮閱. Shihua zonggui qianji 詩話總龜前集. Beijing: Renmin wenxue chubanshe, 1987.

Shao Bo 邵博. Shaoshiwenjian hou lu 邵氏聞見後錄. Beijing: Zhonghua shuju, 1983. Shao Bowen 邵伯溫. Shao shi wenjian lu 邵氏聞見錄. Beijing: Zhonghua shuju, 1983. Shi Jianwu 施肩吾. Xishan qunxian huizhenji 西山群仙會真記. Taipei: Ziyou chubanshe, 1965 .

Sima Guang 司馬光. Zizhi tongjian 資治通鑒. Beijing: Zhonghua shuju, 1956.

Sima Qian 司馬遷. Shiji 史記. Beijing: Zhonghua shuju, 1959.

Su Che 蘇轍. Su Che ji 蘇轍集. Beijing: Zhonghua shuju, 1990.

Su Shi 蘇軾. Dongpo yuefu jian 東坡樂府箋, commentary by Long Yusheng 龍榆生. Shanghai: Shangwu yinshuguan, 1958.

—.Dongpo yuefu 東坡樂府. Beijing: Zhonghua shuju, 1959.

. Dongpo qiji 東坡七集. Taipei: Zhonghua shuju, 1965.

. Dongpo Shu zhuan 東坡書傳. Taipei: Yiwen yinshuguan, 1965.

. Dongpo tiba 東坡題咙. Taipei: Yiwen yinshuguan, 1966.

Su Wenzhonggong shibianzhujicheng 蘇文忠公詩編注集成, commentary by Wang Wengao 王文誥. Taipei: Xuesheng shuju, 1967.

—. Su shi pingzhu huichao 蘇詩評注彙鈔, commentary by Ji Yun 紀昀, edited by Zhao Keyi 趙克宜. Taipei: Xinxing shuju, 1967.

—. Song ke Shi Gu zhu Su shi 宋刻施顧注蘇詩, commentary by Shi Yuanzhi 施元之 and Gu Jingfan 顧景藩. Taipei: Yiwen yinshuguan, 1969.

—. Dongpo yuefu jian 東坡樂府箋, edited by Long Muxun 龍沐勛. Taipei: Shangwu yinshuguan, 1970.

—. Dongpo shi jizhu 東坡詩集注, commentary credited to Wang Shipeng 王十朋. Taipei: Shangwu yinshuguan, 1981.

- Dongpo zhilin 東坡志林. Beijing: Zhonghua shuju, 1981.

. Su Shi shiji 蘇蕙詩集, edited by Kong Fanli 孔凡禮. Beijing: Zhonghua shuju, 1982. 
—.Dongpo quanji 東坡全集. Taipei: Shangwu yinshuguan, 1983.

-Su Shi Wenji 蘇軾文集, edited by Kong Fanli 孔凡禮. Beijing: Zhonghua shuju, 1986.

-Dongpo yuefu biannian jianzhu 東坡樂府編年箋注, edited by Shi Shenghuai 石聲淮 and Tang Lingling 唐玲玲. Wuchang: Huazhong Normal University Press, 1990.

. Dongpo Xiansheng he Tao Yuanming shi 東坡先生和陶淵明詩. Beijing: Zhongguo shudian, 1993.

—.Su shi Yi zhuan 蘇氏易傳. In San Su quanshu 三蘇全書, vol. 1, edited by Zeng Zaozhuang 曾霜莊. Beijing: Yuwen chubanshe, 2001.

-Dongpo biannian shi 東坡編年詩, commentary by Ji Yun 紀昀. Beijing: Beijing Tushuguan chubanshe, 2001.

-Su Shi ci biannian jiaozhu 蘇軾詞編年校注, edited by Zou Tongqing 鄒同慶 and Wang Zongtang 王宗堂. Beijing: Zhonghua shuju, 2002.

. Dongpo chanxi ji 東坡禪喜集, commentary by Feng Mengzhen 馮夢禎 and Ling Mengchu 凌蒙初. Nanjing: Nanjing University Press, 2004.

Su Shi 蘇軾 and Shen Gua 沈括. Su Shen liangfang 蘇沈良方. Taipei: Shangwu yinshuguan, 1975 .

Su Yijian 蘇易簡. Wenfang si pu 文房四譜. $S K Q S$, vol. 843 .

Sun Xidan 孫希旦. Liji jijie 禮記集解. Beijing: Zhonghua shuju, 1989.

Sun Xingyan 孫星衍. Shangshujinguwen zhushu 尚書今古文注疏. Beijing: Zhonghua shuju, 1986.

Sun Yirang 孫詒讓. Zhouli zhengyi 周禮正義. Beijing: Zhonghua shuju, 1987.

Tian Rucheng 田汝成. Xihu youlan zhiyu 西湖遊覽志餘. Beijing: Zhonghua shuju, 1958.

Wang Anshi 王安石. Linchuan xiansheng wenji 臨川先生文集. Beijing: Zhonghua shuju, 1959.

Wang Dang 王讜. Tang yulin jiaozheng 唐語林校證. Beijing: Zhonghua shuju, 1987.

Wang Guan 王琯. Gongsun Longzi xuanjie 公孫龍子懸解. Beijing: Zhonghua shuju, 1992.

Wang Liqi 王利器. Yanshi jiaxun jijie 顏氏家訓集解. Beijing: Zhonghua shuju, 1996.

Wang Ming 王明. Baopuzi neipian jiaoshi 抱朴子內篇校釋. Beijing: Zhonghua shuju, 1985 .

Wang Pingzhen 王聘珍.Dadai lijijiegu 大戴禮記解詁. Beijing: Zhonghua shuju, 1983. Wang Pizhi 王䦕之. Shengshui yantan lu 洍水燕談錄. Beijing: Zhonghuashuju, 1981. Wang Shaoying 汪紹楹, editor. Soushen houji 搜神後記. Beijing: Zhonghua shuju, 1981. Wang Wei 王維. Wang Wei ji jiaozhu 王維集校注. Beijing: Zhonghua shuju, 1997.

Wang Xianqian 王先謙. Shiming shuzheng bu 釋名疏證補. Shanghai: Shanghai guji chubanshe, 1984.

—.Xunzi jijie 苩子集解. Beijing: Zhonghua shuju, 1988. 
Wang Yinglin 王應麟. Kunxue jiwen 困學紀聞. Shanghai: Shanghai guji chubanshe, 2008.

Wen Tong 文同. Danyuanji 丹淵集. $s K Q S$, vol. 1096.

Wu Wenzhi 吳文治, editor. Song shihua quanbian 宋詩話全編. Nanjing: Jiangsu guji chubanshe, 1998 .

Wu Zhaoyi 吳兆宜. Yutai xinyong jianzhu 玉臺新詠箋注. Beijing: Zhonghua shuju, 1985.

Xu Shipei 徐師培. Huaihaijijianzhu 淮海集箋注. Shanghai: Shanghai guji chubanshe, 2000.

Xu Zhen'e 徐震堮. Shishuo xinyu jiaojian 世說新語校箋. Beijing: Zhonghua shuju, 1984.

Xun Yue 荀悅. Qian Han ji 前漢紀. $s K Q S$, vol. 383 .

Yan Zhenyi 閻振益. Xinshu jiaozhu 新書校注. Beijing: Zhonghua shuju, 2000.

Yang Bojun 楊伯峻. Liezi jishi 列子集釋. Beijing: Zhonghua shuju, 1979.

Yang Mingzhao 楊明照. Baopuzi waipianjiaojian 抱朴子外篇校箋. Beijing: Zhonghua shuju, 1991.

—. Zengding wenxin diaolong jiaozhu 增訂文心雕龍校注. Beijing: Zhonghua shuju, 2000.

Yuan Haowen 元好問. Yishan xiansheng wenji 遺山先生文集. Sibu congkan (chubian) 四部叢刊 (初編). Shanghai: Shangwu yinshuguan, n.d.

Yuan Ke 袁珂. Shanhaijing jiaozhu 山海經校注. Shanghai: Shanghai guji chubanshe, 1985.

Yuan Xingpei 袁行雱. Tao Yuanming ji jianzhu 陶淵明集箋注. Beijing: Zhonghua shuju, 2003.

Zeng Gong 曾䐙. Zeng Gong ji 曾珲集. Beijing: Zhonghua shuju, 1998.

Zeng Jili 曾季貍. Tingzhai shihua 艇齋詩話. Hong Kong: Guangwen shuju, 1971.

Zhang Fangping 張方平. Lequan ji 樂全集. SKQS, vol. 1104.

Zhang Junfang 張君房. Yunji qiqian 雲笈七韯. Beijing: Zhonghua shuju, 2003.

Zhang Lei 張未. Zhang Leiji 張未集. Beijing: Zhonghua shuju, 1990.

Zhao Bingwen 趙秉文. Fushuiji 滏水集. SKQS, vol. 1190.

Zhao Ruli 趙汝礪. Beiyuan bielu 北苑別錄. $s K Q S$, vol. 844 .

Zhao Yi 趙翼. Oubei shihua 甌北詩話. Beijing: Renmin wenxue chubanshe, 1963.

Zhou Dunyi 周敦頣. Zhou Lianxi ji 周濂溪集. Congshu jicheng edition. Shanghai: Shangwu yinshuguan, 1936.

Zhu Bian 朱市. Fengyuetang shihua 風月堂詩話. Beijing: Zhonghua shuju, 1988.

Zhu Qianzhi 朱謙之. Laozi jiaoshi 老子校釋. Beijing: Zhonghua shuju, 1984.

Zhu Xi 朱喜. Shijing jizhuan 詩經集傳. In Sishu Wujing 四書五經. Beijing: Zhongguo shudian, 1985 .

.Zhouyibenyi 周易本義. In Sishu Wujing 四書五經. Beijing: Zhongguo shudian, 1985 . 
- Zhongyong zhangju jizhu 中庸章句集注. In Sishu Wujing 四書五經. Beijing: Zhongguo shudian, 1985 .

—.Z Zhu Zi quanshu 朱子全書, edited by Zhu Jieren 朱傑人. Shanghai: Shanghai guji chubanshe \& Hefei: Anhui jiaoyu chubanshe, 2002.

Zhu Yi'an 朱易安, editor. Quan Song biji 全宋筆記 (2006 rpt.). Zhengzhou: Daxiang chubanshe, 2003.

Zhu Zugeng 諸祖耿. Zhanguoce jizhu huikao 戰國策集注匯考. Nanjing: Fenghuang chubanshe, 2008.

\section{Other Sources}

Abrams, M.H. The Mirror and the Lamp:Romantic Theory and the Critical Tradition (1971 rpt.). Oxford: Oxford University Press, 1953.

Adorno, Theodor W. Aesthetic Theory, translated by Robert Hullot-Kentor. Minneapolis: University of Minnesota Press, 1997.

- Notes to Literature, translated by Shierry W. Nicholsen. New York: Columbia University Press, 1992.

Appadurai, Arjun, editor. The Social Life of Things. Cambridge, uk: Cambridge University Press, 1986.

Appiah, Kwame Anthony. Experiments in Ethics. Cambridge, Mass.: Harvard University Press, 2008.

- The Honor Code: How Moral Revolutions Happen. New York: W.W. Norton and Company, Inc., 2010.

Aristotle. Nichomachean Ethics (2nd edition), translated by Terence Irwin. Indianapolis: Hackett Publishing Company, Inc., 1999.

Ashmore, Robert. “The Banquet's Aftermath: Yan Jidao's $\mathrm{C} i$ Poetics and the High Tradition". In T'oung Pao (2002), 88.4-5: 211-50.

Beach, Joseph Warren. The Concept of Nature in Nineteenth-Century English Poetry. New York: Pageant Book Company, 1956.

Belting, Hans. Likeness and Presence: a History of the Image before the Era of Art, translated by Edmund Jephcott. Chicago: University of Chicago Press, 1990.

Benjamin, Walter. Illuminations, translated by Harry Zohn. New York: Schocken Books, 2007.

- Reflections, translated by Edmund Jephcott. New York: Schocken Books, 2007. Berkowitz, Alan J. "Topos and Entelechy in the Ethos of Reclusion in China”. In Journal of the American Oriental Society (1994), 114.4: 632-8.

- Patterns of Disengagement: the Practice and Portrayal of Reclusion in Early Medieval China. Stanford: Stanford University Press, 2000.

Berlin, Isaiah. The Proper Study of Mankind. New York: Farrar, Straus, and Giroux, 2000. 
Bi Xiyan. Creativity and Convention in Su Shi's Literary Thought. New York: Edwin Mellen Press, 2003.

Bokenkamp, Stephen R. "Sources of the Ling-pao Scriptures". In Tantric and Taoist Studies in Honour of R.A. Stein, vol. 2 (1983), published as Mélanges chinois et bouddhiques, 21: 434-86.

Bol, Peter K. Culture and the Way in Eleventh Century China. PhD diss., Princeton University, 1982.

- 'This Culture of Ours': Intellectual Transitions in T'ang and Sung China. Stanford: Stanford University Press, 1992.

Borges, Jorge Luis. Other Inquisitions: 1937-1952, translated by Ruth L.C. Simms. Austin: University of Texas Press, 1964.

Bourdieu, Pierre. Distinction: a Social Critique of the Judgement of Taste, translated by Richard Nice. Cambridge, Mass.: Harvard University Press, 1984.

Budd, Malcolm. The Aesthetic Appreciation of Nature. Oxford: Clarendon Press, 2002.

Büchner, Georg. The Complete Plays, translated by Michael Patterson. New York: Methuen, 1987.

Bush, Susan. The Chinese Literati on Painting. Cambridge, Mass.: Harvard University Press, 1971.

Bush, Susan and Christian Murck, editors. Theories of the Arts in China. Princeton: Princeton University Press, 1983.

Buswell, Robert E. Jr. and Robert M. Gimello, editors. Paths to Liberation: the Mārga and its Transformations in Buddhist Thought. Honolulu: University of Hawaii Press, 1992.

Cahill, James F. "Confucian Elements in the Theories of Painting". In Confucianism and Chinese Civilization, edited by Arthur F. Wright, 77-102. New York: Atheneum, 1964.

Cai, Zong-qi, editor. Chinese Aesthetics: the Ordering of Literature, the Arts, and the Universe in the Six Dynasties. Honolulu: University of Hawaii Press, 2004.

Campany, Robert Ford. "The Meaning of Cuisine of Transcendence in Late Classical and Early Medieval China". In T'oung-Pao (2005), 91.1/3: 1-57.

Celan, Paul. Collected Prose, translated by Rosmarie Waldrop. Manchester: Carcanet Press, 1986.

Chang, H.C. Chinese Literature 2: Nature Poetry. Edinburgh: Edinburgh University Press, 1977.

Chang, Kang-I Sun. The Evolution of Chinese Tz'u Poetry: From Late T'ang to Northern Sung. Princeton: Princeton University Press, 1980.

Chang, Kang-I Sun and Stephen Owen, editors. The Cambridge History of Chinese Literature. Cambridge, uk: Cambridge University Press, 2010.

Cheang, Alice W. The Way and the Self in the Poetry of Su Shih (1037-1101). PhD Diss., Harvard University, 1991.

- "Poetry, Politics, Philosophy: Su Shih as the Man of the Eastern Slope". In Harvard Journal of Asiatic Studies (1993), 53.2: 325-87. 
- "Poetry and Transformation: Su Shih's Mirage". In Harvard Journal of Asiatic Studies (1998), 58.1:147-82.

Chen Guofu 陳國符. Daozangyuanliu kao 道藏源流考. Beijing: Zhonghua shuju, 1963. Chen Zhongzhe 陳中浙. Su Shi shuhua yishu yu fojiao 蘇軾書畫藝術與佛教. Beijing: Zhonghua shuju, 2004.

Chikusa Masaaki 䇥沙雅章. “So Shoku to Bukkyō” 蘇軾と仏教. In Tōhō Gakuhō 東方 学報 (1964), 36: 457-80.

—. So Tōba 蘇東坡. Tokyo: Jinbutsu Ōraisha, 1967.

Clunas, Craig. Superfluous Things: Material Culture and Social Status in Early Modern China. Oxford: Polity Press, 1991.

Coleridge, Samuel Taylor. The Major Works. Oxford: Oxford University Press, 1985.

Danto, Arthur. After the End of Art. Princeton: Princeton University Press, 1997.

"The Artworld". In Aesthetics: the Big Questions, edited by Carolyn Korsmeiyer, 37-40. Oxford: Oxford University Press, 1998.

Deng Guangming 鄧廣銘. Beisong zhengzhi gaigejia Wang Anshi 北宋政治改革家王 安石. Beijing: Renmin wenxue chubanshe, 1997 .

Deng Xiaonan 鄧小南. Songdai wenguan xuanren zhidu zhu cengmiman 宋代文官選 任制度諸層面. Shijiazhuang: Hebei jiaoyu chubanshe, 1993.

, editor. Zhengji kaocha yu xinxi qudao - yi Songdai wei zhongxin 政績考察與 信息渠道——以宋代為中心. Beijing: Peking University Press, 2008.

Doidge, Norman. The Brain That Changes Itself: Stories of Personal Triumph from the Frontiers of Brain Science. New York: Viking Press, 2007.

Du Songbai 杜松柏. Chanxue yu Tang Song shixue 禪學與唐宋詩學. Taipei: Liming wenhua, 1976.

. Chan yu shi 禪與詩. Taipei: Hongdao shuju, 1980.

Ebrey, Patricia Buckley and Peter N. Gregory, editors. Religion and Society in T'ang and Sung China. Honolulu: University of Hawaii Press, 1993.

Egan, Ronald. "Poems on Paintings: Su Shih and Huang T'ing-chien". In Harvard Journal of Asiatic Studies (1983), 43.2: 413-51.

- The Literary Works of Ou-yang Hsiu (1007-72). Cambridge, UK: Cambridge University Press, 1984.

"Ou-yang Hsiu and Su Shih on Calligraphy". In Harvard Journal of Asiatic Studies (1989), 49.2: $365-419$.

—. "Su Shih's 'Notes' as a Historical and Literary Source". In Harvard Journal of Asiatic Studies (1990), 50.2: 561-88.

Word, Image, and Deed in the Life of Su Shi. Cambridge, Mass.: Harvard University Asia Center, 1994.

—. The Problem of Beauty. Cambridge, Mass.: Harvard University Asia Center, 2006.

Eoyang, Eugene. "Moments in Chinese Poetry: Nature in the World and Nature in the Mind". In Studies in Chinese Poetry and Poetics, edited by Ronald C. Miao, 105-28. San Francisco: Chinese Materials Center, 1978. 
Fan Chunya 范春芽. “Su Shi yu Hangzhou shiseng shiwen chouchang ji qi xianghu yingxiang”蘇軾與杭州詩僧詩文酬唱及其相互影響. In Nanchang daxuexuebao 南昌大學學報 (人社版) (2004), 3: 133-7.

Faure, Bernard. Rhetoric of Immediacy. Princeton: Princeton University Press, 1991.

Feng Yuanjun 馮阮君 and Lu Kanru 陸㑆如. Zhongguo shishi 中國詩史. Jinan: Shandong University Press, 1996.

Fiumara, Gemma C. Spontaneity: A Psychoanalytic Inquiry. New York: Routledge, 2009.

Franke, Herbert, editor. Sung Biographies. Wiesbaden: Franz Steiner Verlag, 1976.

Frankel, Hans H. The Flowering Plum and the Palace Lady: Interpretations of Chinese Poetry. New Haven: Yale University Press, 1976.

Freud, Sigmund. On Creativity and the Unconscious. New York: Harper and Row, 1958.

Frodsham, J.D. "The Origins of Chinese Nature Poetry". In Asia Major (1960), 8.1: 68-104.

- The Murmuring Stream: the Life and Works of the Chinese Nature Poet Hsieh Ling-yün (385-433), Duke of K'ang-Lo. Kuala Lumpur: University of Malaya Press, 1967.

_ . "Landscape poetry in China and Europe". In Comparative Literature (1967), 19.3: $193-215$.

- New Perspectives in Chinese Literature. Canberra:Australian National University Press, 1970.

Frye, Northrop. Anatomy of Criticism. Princeton: Princeton University Press, 1957.

Fuller, Michael A. The Road to East Slope. Stanford: Stanford University Press, 1990. "Pursuing the Complete Bamboo in the Breast: Reflections on a Classical Chinese Image for Immediacy". In Harvard Journal of Asiatic Studies (1993), 53.1: 5-23. - "Aesthetics and Meaning in Experience: a Theoretical Perspective on Zhu Xi's Revision of Song Dynasty Views of Poetry". In Harvard Journal of Asiatic Studies (2005), 65: 311-56.

Furuta Shōkin 古田紹欽, editor. Zen to geijutsu 禅と芸術. Tokyo: Perikansha, 1996.

Fu Sinian 傅斯年. Xingming guxun bianzheng 性命古訓辨證. In Fu Sinian quanji, II 傅斯年全集, II.491-736. Taipei: Lianjing chubanshiye gongsi, 1980.

Gaut, Berys and Dominic McIver Lopes, editors. The Routledge Companion to Aesthetics (2nd edition; 2007 rpt.). New York: Routledge, 2005.

Gell, Alfred. Art and Agency: an Anthropological Theory. Oxford: Clarendon Press, 1998. Gladwell, Malcolm. Blink: the Power of Thinking without Thinking. New York: Little, Brown, and Company, 2005.

Outliers: the Story of Success. New York: Little, Brown, and Company, 2008.

Gombrich, Ernst. Nature and Art as Needs of the Mind: the Fourth Leverhulme Memorial Lecture. Liverpool: Liverpool University Press, 1981.

Gong Pengcheng 竟鵬程. Jiangxi shishe zongpai yanjiu 江西詩社宗派研究. Taipei: Wenshizhe chubanshe, 1983 .

Gong Yanming 龔延明. Songdai guanzhi cidian 宋代官制辭典. Beijing: Zhonghua shuju, 1997. 
Graham, A.C. Reason and Spontaneity. Totowa, NJ: Barnes and Noble, 1985.

-Disputers of the Tao:Philosophical Argument in Ancient China. La Salle, Ill.: Open Court, 1989.

Grant, Beata. Mount Lu Revisited: Buddhism in the Life and Writings of Su Shi. Honolulu: University of Hawaii Press, 1994.

Gregory, Peter N., editor. Sudden and Gradual: Approaches to Enlightenment in Chinese Thought. Honolulu: University of Hawaii Press, 1987.

Gregory, Peter N. and Daniel A. Getz, editors. Buddhism in the Sung. Honolulu: University of Hawaii Press, 1999.

Gumbrecht, Hans Ulrich. Production of Presence: What Meaning Cannot Convey. Stanford: Stanford University Press, 2004.

Hadot, Pierre. The Veil of Isis: an Essay on the History of the Idea of Nature, translated by Michael Chase. Cambridge, Mass.: Harvard University Press, 2006.

Hargett, James M. "Clearing the Apertures and Getting in Tune: The Hainan Exile of Su Shi (1037-1101)". In Journal of Song-Yuan Studies (2000), 30: 141-67.

Hartman, Charles. "Poetry and Politics in 1079:The Crow Terrace Poetry Case of Su Shih". In Chinese Literature: Essays, Articles, Reviews (CLEAR) (1990), 12:15-44.

—. "The Inquisition against Su Shih: His Sentence as an Example of Sung Legal Practice". In Journal of the American Oriental Society (1993), 113.2: 228-43.

Hartwell, Robert. "Financial Expertise, Examinations, and the Formulation of Economic Policy in Northern China". In Journal of Asian Studies (1971), 30: 281-314.

Hawes, Colin S.C. The Social Circulation of Poetry in Mid-Northern Song. Albany: SUNY, 2005 .

Hawkes, David. "The Quest of the Goddess". In Asia Major 13 (1967): 71-94. . The Poetry of T'ao Ch'ien. Oxford: Clarendon Press, 1970.

Hegel, Georg Wilhelm Friedrich. Introductory Lectures on Aesthetics (2004 rpt.), translated by Bernard Bosanquet. London: Penguin Books, 1993.

Hegel, Robert E. "The Sights and Sounds of Red Cliffs: on Reading Su Shi”. In Chinese Literature: Essays, Articles, Reviews (CLEAR) (1998), 20: 11-30.

Heidegger, Martin. Vorträge und Aufsätze. Tübingen: Günther Meske Pfullingen, 1954.

- On the Way to Language, translated by Peter D. Hertz. New York: HarperCollins Publishers, 1971.

_. Basic Writings (1993 rpt.), edited by David Farrel Krell. New York: HarperCollins Publishers, 1977.

—. Hölderlin's Hymn 'The Ister', translated by William McNeill and Julia Davis. Indianapolis: Indiana University Press, 1984.

Hervouet, Yves. A Sung Bibliography. Hong Kong: Chinese University Press, 1978.

Hightower, James Robert. The Poetry of T'ao Ch'ien. Oxford: Clarendon, 1970.

Hightower, James Robert and Chia-ying Yeh. Studies in Chinese Poetry. Cambridge, Mass.: Harvard University Asia Center, 1998. 
Hisamatsu Shin'ichi 久松真一. Tōyō teki mu 東洋的無. Tokyo: Risōsha, 1969.

—. Zen to geijutsu 禅と芸術 (1975 3rd rpt.). Tokyo: Risōsha, 1970.

Hokari Yoshiaki 保获佳昭. “Tōba ni totte no shi no imi: toku ni shi to hikaku shite” 東 坡にとつての詞の意味一特に詩と比較して. In Kangaku kenkyu 漢學研究 (1987), 3: 21-38.

—— “So Shoku no So Tetsu ni kan suru shi shi ni tsuite” 蘇軾の蘇轍に關する詩 詞について. In Ganlan 橄欖 (2005), 13: 131-49.

Huang Qifang 黃啟方. Huang Tingjian yu Jiangxi shipai lunji 黃庭堅與江西詩派論 集. Taipei: Guojia chubanshe, 2006.

Hucker, Charles. A Dictionary of Officials Titles in Imperial China. Taipei: Southern Materials Center, 1985 .

Hu Fuchen 胡孚琛, editor. Zhonghua daojiao dacidian 中華道教大辭典. Beijing: Zhongguo shehuikexue chubanshe, 1995.

Hussein, Farzeen Baldrian. "Inner Alchemy: Notes on the Origin and Use of the Term neidan". In Cahiers d'Extrême-Asie (1989), 5: 163-90.

Jiang Qian 江謙. Dongpo chanxue shiwen yaojie 東坡禪學詩文要解. Shanghai: Foxue shuju, 1947 .

Jiang Shengdiao 姜聲調. Su Shi de Zhuangzi xue 蘇軾的莊子學. Taipei: Wenjin chubanshe, 1998.

Jin Shengyang 金生楊. Su shi Yi zhuan yanjiu 《蘇氏易傳》研究. Chengdu: Bashu chubanshe, 2002.

Jung, Carl Gustav. The Archetypes and the Collective Unconscious (2nd edition), translated by R.F.C. Hull. London: Routledge and Kegan Paul, 1968.

Kachi, Yukio. "Review: Graham's Reason and Spontaneity". In Philosophy East and West (1990), 40.3: 389-98.

Kaguraoka Masatoshi 神楽岡昌俊.Chūgoku niokeru in’itsu shisōno kenkyū 中国にお ける隱逸思想の研究. Tokyo: Perikansha, 1993 .

Kahneman, Daniel. Thinking, Fast and Slow. New York: Farrar, Straus and Giroux, 2011.

Kant, Immanuel. Critique ofJudgement (2007 rpt.), translated by James Creed Meredith. Oxford: Oxford University Press, 1952.

Keith, W.J. The Poetry of Nature: Rural Perspectives in Poetry from Wordsworth to the Present. Toronto: University of Toronto Press, 1980.

Knechtges, David R. The Han Rhapsody: A Study of the Fu of Yang Hsiung. Cambridge, UK: Cambridge University Press, 1976.

-Wenxuan, or Selections of Refined Literature. Princeton: Princeton University Press, 1996.

Kohn, Livia, editor. Taoist Meditation and Longevity Techniques. Ann Arbor: University of Michigan, 1989 .

. "Eternal Life in Taoist Mysticism". In Journal of the American Oriental Society (1990), 110.4: 622-40. 
- "Transcending Personality: from Ordinary to Immortal Life". In Taoist Resources

(1991), 2.2: 1-22.

Kong Fanli 孔凡禮. Su Shi nianpu 蘇軾年譜. Beijing: Zhonghua shuju, 1998.

—.Su Che nianpu 蘇轍年譜. Beijing: Xueyuan chubanshe, 2001.

. San Su nianpu 三蘇年譜. Beijing: Zhonghua shuju, 2004.

Kooy, Michael J. Coleridge, Schiller and Aesthetic Education. New York: Palgrave, 2002.

Kubin, Wolfgang. Der Durchsichtige Berg: die Entwicklung der Naturanschauung in der chinesischen Literatur. Stuttgart: Franz Steiner Verlag, 1985.

Kwong, Charles Yim-tze. "Naturalness and Authenticity: The Poetry of Tao Qian". In Chinese Literature: Essays, Articles, Reviews (CLEAR) (1989), 11: 35-77.

—. Tao Qian and the Chinese Poetic Tradition: The Quest for Cultural Identity. Ann Arbor: Center for Chinese Studies, University of Michigan, 1994.

Lackner, Michael. "Holy Within and Without: Zhang Zai's Teachings of Confucius's Two Natures”. In Higashi ajia bunka kōjū kenkyu (bessatsu) 東アジア文化交渋研究 (別冊) (2008), 3: 25-40.

LaFleur, William R. "Saigyō and the Buddhist Value of Nature". In History of Religions (1973, 1974), (Part I) 13.2: 93-128, and (Part II) 13·3: 227-48.

Lang, Berel. "Style as Instrument, Style as Person". In Critical Inquiry (1978), 4.4: 715-39.

Lee, Brigitta. "Imitation, Remembrance and the Formation of the Poetic Past in Early Medieval China". PhD diss., Princeton University, 2007.

Leng Chengjin 冷成金. Su Shi de zhexue guan yu wenyi guan 蘇軾的哲學觀與文藝 觀. Beijing: Xueyuan chubanshe, 2003.

Leotard, Jean-François. The Inhuman: Reflections on Time, translated by Geoffrey Bennington and Rachel Bowlby. Stanford: Stanford University Press, 1991.

Lewis, M.M. Language Thought and Personality in Infancy and Childhood. London: George G. Harper Co. Ltd., 1963.

Li Chi. "The Changing Concept of the Recluse in Chinese Literature". In Harvard Journal of Asiatic Studies (1962/63), 24: 234-47.

Li Jinshui 李金水. Wang Anshi jingji bianfa yanjiu 王安石經濟變法研究. Fuzhou: Fujian renmin chubanshe, 2007.

Li Gengyang 李賡揚 and Li Boyang 李勃洋. Xiaosa rensheng: Su Shiyu fochan 潚灑人 生：蘇軾與佛禪. Zhengzhou: Henan renmin chubanshe, 2001.

Li Hongxia 李紅霞. “Lun Tangdai taoyuan yixiang de xinbian” 論唐代桃源意象的新 變. In Xinan minzuxueyuan xuebao (zhesheban) 西南民族學院學報 (哲社版) (2002), 1: 119-23.

Li Yibing 李一冰. Su Dongpo xin zhuan 蘇東坡新傳. Taipei: Lianjing chuban, 1983. Liang Gengyao 梁庚堯. Songdai shehui jingji shi lun ji 宋代社會經濟史論集. Taipei: Yunchen chubanshe, 1997.

Lin Tianwei 林天蔚. Tang Song shiyanjiu 唐宋史研究. Hong Kong: University of Hong Kong, 1987 . 
Lin, Shuen-fu. The Transformation of the Chinese Lyrical Tradition: Chiang K'uei and Southern Sung tz'u poetry. Princeton: Princeton University Press, 1978.

Lin, Shuen-fu and Stephen Owen, editors. The Vitality of the Lyric Voice. Princeton: Princeton University Press, 1986.

Lin Yutang 林語堂. The Gay Genius: the Life and Times of Su Tungpo. New York: J. Day Co., 1947 .

Liouyi Yuh. "Liu Yung, Su Shih, and Some Aspects of the Development of Early Tz'u Poetry". PhD diss., University of Washington, 1972.

Liu Guojun 劉國珺. Su Shi wenyi lilun yanjiu 蘇軾文藝理論研究. Tianjin: Nankai daxue chubanshe, 1984 .

Liu, James J.Y. Chinese Theories of Literature. Chicago: University of Chicago Press, 1975. Liu, James T.C. Reform in Sung China: Wang An-shih (1021-1086) and His New Policies. Cambridge, Mass.: Harvard University Press, 1959.

Liu Shangrong 劉尚榮. Su Shi zhuzuo banben luncong 蘇軾著作版本論叢. Chengdu: Bashu shushe, 1988.

Liu Shi 劉石. Su Shi ci yanjiu 蘇軾詞研究. Taipei: Wenjin chubanshe, 1992.

Liu Weichong 劉維崇. Su Shi pingzhuan 蘇軾評傳. Taipei: Liming wenhua, 1978.

Lu Yang 盧央. Ge Hong pingzhuan 暮洪評傳. Nanjing: Nanjing daxue chubanshe, 2006.

Lu Yongfeng 陸永峰. “Tangdai sengshi gailun” 唐代僧詩概論. In Wenyixue yanjiu 文 學遺產研究 (2002), 3: 368-78.

Luo Ning 羅寧 and Wu Lixia 武麗霞. “Su Shi Su Che wenzhuan shulun:jianlun Beisong wenzhuan” 蘇軾蘇䡴文傳述論一兼論北宋文傳. Paper presented at the 18 th International Su Shi Studies Conference, Leshan, 2013. Printed in the conference anthology.

Lyotard, Jean-François. The Inhuman: Reflections on Time, translated by Geoffrey Bennington and Rachel Bowlby. Stanford: Stanford University Press, 1991.

Ma Doucheng 馬斗成. Songdai Meishan Su shi jiazuyanjiu 宋代眉山蘇氏家族研究. Beijing: Zhongguo shehui kexue chubanshe, 2005.

Mannheim, Karl. Ideology and Utopia: an Introduction to the Sociology of Knowledge, translated by Louis Wirth and Edward Shils. San Diego: A Harvest Book, 1936.

Marther, Richard B. "The Landscape Buddhism of the Fifth Century Poet Hsieh Lingyun". In Journal of Asia Studies (1958), 18.1: 67-79.

- "Shen Yueh's Poems of Reclusion: from Total Withdrawal to Living in the Suburbs". In Chinese Literature: Essays, Articles, Reviews (CLEAR) (1983), 5.1/2: $53-66$.

Mauss, Marcel. The Gift: the Form and Reason for Exchange in Archaic Societies, translated by W.D. Halls. New York: W.W. Norton, 1990.

Meng Naichang 孟乃昌. Zhouyi cantongqi kaobian 周易參同契考辯. Shanghai: Shanghai guji chubanshe, 1993 .

Miao, Ronald C., editor. Studies in Chinese Poetry and Poetics. San Francisco: Chinese Materials Center, 1978. 
Miller, James Whipple. "English Romanticism and Chinese Nature Poetry”. In Comparative Literature (1972), 15.2: 216-36.

Misaki Gisen 三崎義泉. Shikanteki biishiki no tenkai: chūsei geidō to hongaku shisō to no kanren 止観的美意識の展開: 中世芸道と本覚思想との関連. Tokyo: Perikansha, 1999 .

Mo Lifeng 莫礪鋒.Jiangxi shipaiyanjiu 江西詩派研究. Jinan: Qilu shushe, 1986.

Mollier, Christine. Buddhism and Taoism Face to Face: Scripture, Ritual, and Iconographic Exchange in Medieval China. Honolulu: University of Hawaii Press, 2008.

Moore, Ronald. Natural Beauty: a Theory of Aesthetics beyond the Arts. Ontario: Broadview Press, 2008.

Murck, Alfreda and Wen Fong, editors. Words and Images: Chinese Poetry, Calligraphy, and Painting. The Metropolitan Museum of Art and Princeton University Press, 1991.

Murray, Patrick T. The Development of German Aesthetic Theory from Kant to Schiller. Lewiston: Edwin Mellen Press, 1992.

Needham, Joseph and Lu Gwei-Djen. Spagyrical Discovery and Invention: Physiological Alchemy. In Science and Civilization in China, pt.5. Cambridge, uk: Cambridge University Press, 1983.

Nelson, Susan. "On through to the Beyond: the Peach Blossom Spring as Paradise". In Archives of Asian Art (1986), 39: 23-47.

Nihon bukkyōgakkai 日本佛教学会, editor. Bukkyō to shizen 仏教と自然. Kyoto: Heirakuji shoten, 2003.

Nishino Jōji 西野貞治. “Tōba shi no kaida no kotoba nit suite” 東坡詩の買田の語に ついて.In Jinbun kenkū 人文研究 (1968), 3: 21-7.

“Kōshū tsūhan zaininchū So Shoku no kōyū nit suite” 杭州通判在任中の蘇 軾の交友について.In Jinbun kenkū 人文研究 (1970), 3: 57-70.

—. “So Shoku to Genyū tōsō kachū no hitobito” 蘇軾と元祐党争渦中の人々. In Jinbun kenkū 人文研究 (1972), 1: 35-49.

Nukariya Kaiten 忽滑谷快天.Zengakushisōshi 禪學思想史.Tokyo: Meicho Kankōkai, 1969.

Nylan, Michael. The Five 'Confucian' Classics. New Haven: Yale University Press, 2001.

Ogawa Tamaki 小川環樹. Ogawa Tamaki chosakushū 小川環樹著作集. Tokyo: Chikuma Shobō, 1997.

Owen, Stephen. "The Formation of the Tang Estate Poem”. In Harvard Journal of Asiatic Studies (1995), 55.1: 39-59.

—. The End of Chinese 'Middle Ages': Essays in Mid-Tang Literary Culture. Stanford: Stanford University Press, 1996.

- The Late Tang: Chinese poetry of the mid-ninth century. Cambridge, Mass.: Harvard University Asia Center, 2006.

Palumbo-Liu, David. The Poetics of Appropriation: the Literary Theory and Practice of Huang Tingjian. Stanford: Stanford University Press, 1993. 
Pregadio, Fabrizio. Great Clarity: Daoism and Alchemy in Early Medieval China. Stanford: Stanford University Press, 2006.

Plato. The Republic of Plato (1991 rpt.), translated by Allan Bloom. New York: Perseus Books Group, 1968.

- Selected Dialogues of Plato, translated by Benjamin Jowett. New York: Modern Library, 2001.

Pye, Michael. Skilful Means. Dallas: Gerald Duckworth and Co. Ltd, 1978.

Qi Xia 漆俠. Wang Anshibianfa 王安石變法. Shijiazhuang: Hebei renmin chubanshe, 2001.

Qian Zhongshu 錢鍾書. Tan yi lu 談藝錄. Beijing: Sanlian shudian, 2001. - Song shi xuan zhu 宋詩選注. Beijing: Sanlian shudian, 2002.

Qiu Dewen 邱德文, Wu Jiarong 吳家榮 and Xia Tongyan 夏同衍, editors. Bencao gangmu caise yao tu 本草綱目彩色藥圖. Guizhou: Guizhou keji chubanshe, 1998.

Richter, Antje. "Beyond Calligraphy: Wang Xizhi's Letters". In Toung-Pao (2011), 96: $370-407$.

Riedel, Manfred. Kunst als 'Auslegerin der Natur.' Cologne: Böhlau Verlag GmbH and Cie, 2001.

Robertson, Maureen A. “...To Convey What Is Precious: Ssu-K'ung T'u's Poetics and the Erh-shih-ssu Shih P'in". In Transition and Permanence, edited by David C. Buxbaum and Frederick W. Mote, 323-53. Hong Kong: Cathay Press Ltd., 1972.

Robinet, Isabelle. "Metamorphosis and Deliverance from the Corpse in Taoism". In History of Religion (1979), 19.1: 37-70.

__. "Sur le sens des termes waidan et neidan". In Taoist Resources (1991), 3.1: 3-40.

- Taoist Meditation: the Mao-shan Tradition of Great Purity, translated by Julian F. Pas and Norman J. Girardot. Albany: State University of New York Press, 1993.

Röllicke, Hermann-Josef. 'Selbst-Erweisung': der Ursprung des Ziran-Gedankens in der chinesischen Philosophie des 4. und 3. Jhs. v. Chr. Frankfurt: Peter Language, 1996.

Ryden, Edmund, translator. Daodejing. Oxford: Oxford University Press, 2008.

Saussy, Haun. The Problem of a Chinese Aesthetic. Stanford: Stanford University Press, 1993.

Schiller, Johann C.F. von. On the Aesthetic Education of Man, translated by Reginald Snell. Mineola: Dover Publications, Inc., 2004.

Schipper, Kristofer. The Taoist Body, translated by Karen C. Duval. Berkeley: University of California Press, 1993.

Seel, Martin. Eine Ästhetik der Natur (Frankfurt: Suhrkamp Verlag, 1991.

Sharf, Robert H. "On Pure Land Buddhism and Ch'an/ Pure Land Syncretism”. In T'oungPao (2002), 88: 282-331.

Shen Songqin 沈松勤. Beisong wenren yu dangzheng 北宋文人與黨爭. Beijing: Renmin chubanshe, 1998. 
Shi Tianhong 釋天宏. “Kuo'an 'Shiniutu song' kao: cong muniutu song tanqi” 廓庵《十牛圖頌》考：從牧牛圖頌談起. In Shijie zongjiao xuekan 世界宗教 學刊 (2011), 17: 123-54.

Shields, Anna M. "Remembering When: the Uses of Nostalgia in the Poetry of Bai Juyi and Yuan Zhen." In Harvard Journal of Asiatic Studies 66.2 (2006): 321-61.

Sichuan daxue zhongwenxi 四川大學中文系, editors. Su Shi yanjiu zhuanji 蘇軾研 究專輯. Chengdu: Sichuan renmin chubanshe, 1980.

—.Su Shiziliao huibian 蘇軾資料彙編. Beijing: Zhonghua shuju, 1994.

Siebert, Martina. Pulu: 'Abhandlungen und Auflistungen' zu materieller Kultur und Naturkunde im traditionellen China. Wiesbaden: Harrassowitz Verlag, 2006.

Silbergeld, Jerome. “The Yuan 'Revolutionary' Picnic: Feasting on the Fruits of Song (A Historiographic Menu)". In Ars Orientalis (2009), 37: 9-31.

Smith, Kidder Jr., Peter K. Bol, Joseph A. Adler and Don J. Wyatt. Sung Dynasty Uses of the I Ching. Princeton: Princeton University Press, 1990.

Sturman, Peter Charles. Mi Fu: Style and the Art of Calligraphy in Northern Song China. New Haven: Yale University Press, 1997.

Sun Changwu 孫昌武. Chansi yu shiqing 禪思與詩情. Beijing: Zhonghua shuju, 1997. Su Shi yanjiu xuehui 蘇軾研究學會, editor. Dongpo ci luncong 東坡詞論叢. Chengdu: Sichuan renmin chubanshe, 1982.

, editor. Dongpo shi luncong 東坡詩論叢. Chengdu: Sichuan renmin chubanshe, 1983.

—, editor. Dongpo yanjiu luncong 東坡研究論叢. Chengdu:Sichuan renmin chubanshe, 1986.

—, editor. Lun Su Shi Lingnan shi ji qita 論蘇軾嶺南詩及其他. Guangzhou: Guangdong renmin chubanshe, 1986.

Suzuki, D.T. Manual of Zen Buddhism. London: Rider and Company, $195^{\circ}$.

Svarverud, Rune. "The Usefulness of Uselessness". In Studies in Chinese Language and Culture, edited by Christoph Anderl and Halvor Eifring, 159-68. Oslo: Hermes Academic Publishing, 2006.

Swanson, Paul L. Foundations of T'ien-T'ai Philosophy: the Flowering of the Two Truths Theory in Chinese Buddhism. Berkley: Asian Humanities Press, 1989.

Swartz, Wendy. Reading Tao Qian: Shifting Paradigms of Historical Reception (427-190o). Cambridge, Mass.: Harvard University Asia Center, 2008.

—. "Naturalness in Xie Lingyun's Poetic Works". In Harvard Journal of Asiatic Studies (2010), 70.2: $355^{-86 .}$

Tang Lingling 唐玲玲 and Zhou Weimin 周偉民. Su Shi sixiangyanjiu 蘇軾思想研究. Taipei: Wenshizhe chubanshe, 1996.

Tang Yongtong 湯用䑣. Han Wei Liangjin Nanbeichao fojiao shi 漢魏兩晉南北朝佛 教史. Beijing: Zhonghua shuju, 1955. 
Tian Xiaofei. Tao Yuanming and Manuscript Culture: The Record of a Dusty Table. Seattle: University of Washington Press, 2005.

Tiang, Seng-yong. "Huang T'ing-chien (1045-1105) and the Use of Tradition”. PhD diss., University of Washington, 1976.

Thomson, Garrett and Marshall Missner. On Aristotle. Belmont: Wadsworth, 2000.

Tomlonovic, Kathleen M. "Poetry of Exile and Return: A Study of Su Shi”. PhD diss., University of Washington, 1989.

Uchiyama Seiya 內山精也. “Tōba Utai Shi’an ryūten kō” 「東坡烏台詩案」流伝考. In Yokohama Shiritsu Daigaku ronsō 横浜市立大学論叢 (1996), 47·3: 111-48.

Uchiyama Seiya 內山精也. Chuanmei yu zhenxiang: Su Shi ji qi zhouwei shidafu de wenxue 傳媒與真相 : 蘇軾及其周圍士大夫的文學, translated by Zhu Gang 朱 剛. Shanghai: Shanghaiguji chubanshe, 2005.

Verellen, Franciscus. "Evidential Miracles in Support of Taoism, the Inversion of a Buddhist Apologetic Tradition in Late-Tang China". In T'oung Pao (1993), 78:217-63. Vervoorn, Aat. Men of the Cliffs and Caves: the Development of the Chinese Eremitic Tradition to the End of the Han Dynasty. Hong Kong: The Chinese University Press, 1990.

—. "Review on Berkowitz, Patterns of Disengagement". In Harvard Journal of Asiatic Studies (2002), 62.1: 247-56.

Waley, Arthur. "Notes on Chinese Alchemy, Supplementary to Johnson's 'Study of Chinese Alchemy". In Bulletin of the School of Oriental Studies (1930), 6.1: 1-24.

Wang Daiwen 王代文, editor. Zhonghua guyan 中華古硯. Nanjing: Jiangsu guji chubanshe, 1998.

Wang Guowei 王國維. Renjian cihua 人間詞話. In Wang Guoweiwenxue meixue lunzhu $j i$ 王國維文學美學論著集, 348-68. Taiyuan: Beiyue wenyi chubanshe, 1987.

Wang Liqi 王利器. Ge Hong lun 葛洪論. Taipei: Wunan tushu chubangongsi, 1997.

Wang Shuizhao 王水照. Su Shi lungao 蘇軾論稿. Taipei: Wanjuanlou, 1994.

- Su Shi zhuan: zhizhe zai kunan zhong de chaoyue 蘇軾傳：智者在苦難中的 超越. Tianjin: Tianjin renmin chubanshe, 2000.

Wang Shuizhao 王水照 and Zhu Gang 朱剛. Su Shi pingzhuan 蘇軾評傳. Nanjing: Nanjing daxue chubanshe, 2004.

Wang Xiulin 王秀林. “Wan-Tang Wudai shiseng de yinpi ji qi chengyin” 晚唐五代詩 僧的吟癖及其成因. In Shoudu Shifan Daxue xuebao (zhesheban) 首都師範大學 學報 (哲社版) (2004), 5:67-72.

Wang Yugen. "Poetry in Print Culture: Texts, Reading Strategy, and Compositional Poetics in Huang Tingjian (1045-1105) and the Late Northern Song”. PhD diss., Harvard University, 2005 .

Wang Zhaopeng 王兆鵬. “Tang Yanqian sishishou yanshi zhengwei” 唐彥謙四十首 贋詩證偽. In Zhonghua wenshi luncong 中華文史論叢 (1993), 52: 226-44. 
Watson, Burton. Selected Poems of Su Tung-P'o. Copper Canyon Press, 1994. An expansion on Su Tung-P'o: Selections from a Sung Dynasty Poet. New York: Columbia University Press, 1965 .

Weinrich, Harald. Lethe: Kunstund Kritikdes Vergessens (2nd edition). Munich: C.H. Beck, 2005 .

Westbrook, Francis A. "Landscape Transformation in the Poetry of Hsieh Ling-yun". In Journal of the American Oriental Society (1980), 100: 237-54.

Wordsworth, William and Samuel Taylor Coleridge. Lyrical Ballads. New York: Barnes and Noble, 1963.

Wu Rujun 吳汝均. Youxi sanmei: Chan de shijian yu zhongji guanhuai 遊戲三昧 : 禪 的實践與終極關懷. Taipei: Xuesheng shuju, 1993.

Wu Xiaoman 伍曉蔓.Jiangxi zongpaiyanjiu 江西宗派研究. Chengdu: Bashu shushe, 2005 .

Wu Xuetao 吳雪濤. Su wen xinian kaolue 蘇文系年考略. Hohhot: Neimenggu jiaoyu chubanshe, 1990.

Wu Zongci 吳宗慈. Lushan zhi 盧山志. Nanchang: Jiangxi renmin chubanshe, 1996.

Xie Minling 謝敏玲. Su Shi shilun sanwen yanjiu 蘇軾史論散文研究. Taipei: Wanjuanlou, 2000.

Xu Yuefeng 徐月芳. Su Shi zouyi shudu yanjiu 蘇軾奏議書牘研究. Taipei: Tiangong shuju, 2002.

Xue Ruisheng 薛瑞生. “Su men, Su xue, yu Su ti” 蘇門、蘇學與蘇體. In Wenxue yichan 文學遺產 (1988), 5: 60-8.

Yang Cunchang 楊存昌.Daojia sixiangyu Su Shimeixue 道家思想與蘇軾美學.Jinan: Jinan chubanshe, 2003 .

Yang, Xiaoshan. Metamorphosis of the Private Sphere: Gardens and Objects in Tang-Song Poetry. Cambridge, Mass.: Harvard University Asia Center, 2003.

Yang, Vincent. Nature and Self: a Study of the Poetry of Su Dongpo, with Comparisons to the Poetry of William Wordsworth. New York: Peter Lang Publishing Inc., 1989.

Yang, Zhiyi. "Zhu Xi as Poet”. In Journal of the American Oriental Society (2012), 132.4, $587-611$.

—. "Su Shi". In Berkshire Dictionary of Chinese Biography, edited by Kerry Brown, 684-97. Berkshire Publishing, 2014.

Yeh Chia-ying 葉嘉瑩. Su Shi 蘇軾. Taipei: Da'an chubanshe, 1988.

Yip, Wai-Lim. "Aesthetic Consciousness of Landscape in Chinese and Anglo-American Poetry". In Comparative Literature Studies (1978), XV.2: 211-41.

Yoshikawa Kōjirō 吉川幸次郎, editor. Chūgoku bungaku ronshū 中国文学論集. Tokyo: Shinchōsha, 1966.

- An Introduction to Sung Poetry, translated by Burton Watson. Cambridge, Mass.: Harvard University Press, 1967.

Yu, Pauline. The Poetry of Wang Wei. Bloomington: Indiana University Press, 1980. 
. The Reading of Imagery in the Chinese Poetic Tradition. Princeton: Princeton University Press, 1987.

— 1994.

Yuan Xingpei 袁行霃. Tao Yuanming yanjiu 陶淵明研究. Beijing: Peking University Press, 1997 .

—. “Lun 'Hetao shi' ji qi wenhua yiyun” 論和陶詩及其文化意蘊. In Zhongguo shehui kexue 中國社會科學 (2003), 6: 149-61.

Zeng Zaozhuang 曾疋庄. Su Shi pingzhuan 蘇軾評傳. Chengdu: Sichuan renmin chubanshe, 1984 .

—. San Su yanjiu 三蘇研究. Chengdu: Bashu shushe, 1999.

—.Su Shi yanjiu shi 蘇軾研究史. Nanjing: Jiangsu jiaoyu chubanshe, 2001.

Zhang Guogang 張國剛. Foxue yu Sui Tang shehui 佛學與隋唐社會. Shijiazhuang: Hebei renmin chubanshe, 2002.

Zhang Longxi. The Tao and the Logos. Durham: Duke University Press, 1992.

- Allegoresis: Reading Canonical Literature East and West. Ithaca: Cornell University Press, 2005.

Zhang Quancai 章權才. Song Ming jingxue shi 宋明經學史. Shaoguan: Guangdong renmin chubanshe, 1999 .

Zhang Sanxi 張三夕. “Lun Su shi zhong de kongjian gan” 論蘇詩中的空間感. In Wenxue yichan 文學遺產 (1988), 2: 87-96.

Zhang Xiqing 張希清. Songchao dianzhang zhidu 宋朝典章制度. Changchun: Jilin wenshi chubanshe, 2001.

Zhao Yiwu 趙以武. Changhe shi yanjiu 唱和詩研究. Lanzhou: Gansu wenhua chubanshe, 1997.

Zheng Fangxiang 鄭芳祥. Chuchu sisheng: Su Shi bianzhe Lingnan wenxue zuopin zhuti yanjiu 出處死生：蘇軾貶謫嶺南文學作品主題研究. Chengdu: Bashu shushe, 2006.

Zheng Shaozong 鄭紹宗. “Han yan ziliao size” 漢硯資料四則. In Wenwu 文物 (1964), 10: $42-3,36$.

Zhong Laiyin 鐘來因. Su Shi yu daojia daojiao 蘇軾與道家道敎. Taipei: Xuesheng shuju, 1990.

Zhou Yukai 周裕鍇. Zhongguo chanzong yu shige 中國禪宗與詩歌. Shanghai: Shanghai renmin chubanshe, 1992.

—. Songdai shixue tonglun 宋代詩學通論. Chengdu: Bashu shushe, 1997. . Wenzi chan yu Songdai shixue 文字禪與宋代詩學. Beijing: Gaodeng jiaoyu chubanshe, 1998.

- "Menghuan yu zhenru: Su Huang de chanyue qingxiang yu qi shige yixiang zhi guanxi” 夢幻與真如 : 蘇黃的禪悅傾向與其詩歌意象之關係. In Wenxueyichan 文學遺產 (2001), 3: 68-75. 
“Shi keyi qun: luetan Yuanyouti shige de jiaoji xing” 詩可以群: 略談元祐體 詩歌的交際性. In Shehui kexueyanjiu 社會科學研究 (2001), 5:129-34.

Zhu Chuanyu 朱傳譽, editor. Su Shi zhuanji ziliao 蘇軾傳記資料. Taipei: Tianyi chubanshe, 1982.

Zhu Jinghua 朱靖華. Su Shixin lun 蘇軾新論. Jinan: Qilu shushe, 1983. - Su Shi lun 蘇軾論. Beijing: Jinghua chubanshe, 1997.

Zhu Shangshu 祝尚書. Songdai keju yu wenxue kaolun 宋代科舉與文學放論. Zhengzhou: Daxiang chubanshe, 2006.

Žižek, Slavoj. Event: Philosophy in Transit. London: Penguin Books, 2014. 


\section{Index}

Adorno, Theodor W. $\quad 6,89$

aestheticisation

and anxiety over possession and commoditisation 105

and fear of losing the Way $27-28$

of inkstabs $\quad 96-98$

and the usefulness of uselessness 20, 87,

105

Ai Weiwei 11

\section{Analects}

Confucius's praise of Yan Hui (6.7) 31

on not being a bitter gourd 91

silence on human nature and the Way of

Heaven 28, 30

story of Ziyou's teaching of the Odes 139

on teaching of 'for oneself' (weiji) 141

Zilu mocked by recluses story in 141085

Anqi. See Scholar Anqi

Appadurai, Arjun 104, 108

artistic spontaneity, works of art as a part of 11

Ashmore, Robert 121

attachment

to form challenged in the Vimalakìrti Sütra

47

to language and Su Shi's 'spontaneous'

expression of his nature 25

memorisation as a form of 65

to superfluous things as a moral threat 20 , 91

Su Shi's attachment to the name of Snow Hall 73,76

Su Shi's 'non-attachment' theory 50, 115

Belting, Hans $\quad 3-4$ n5

Benjamin, Walter 88

Berkowitz, Alan J. 92

Berlin, Isaiah 145

birds

burtcherbird tongue of Hainan local dialect $131-132,133$

'freedom' of songs of 88

peng bird from Zhuangzi 92, 99, 113,

$113 n 94$

river gulls in a story in Liezi 131
Bo Juyi

attempt to produce cinnabar pellets 171

Bo-ti 25

Dongpo ('East Slope') gardening immitated by Su Shi 69

gift exhange with Pei Du 110-111, 110n83

and Yuan Zhen 124

Bol, Peter K. 29, 33

Book of Changes

combined with Buddhist and Confucian ideas in Su Shi's essay for Sicong $35^{-}-36$

hexagrams qian, kun, kan, and, li 178-179 numeric cosmology of $34 \mathrm{n} 47,172$

Su Shi's commentary on $32,100,144,172$, 189,200

trigram, li $181 \mathrm{n} 82$

Xici chapter 26-27, 34n47, 199n131

Book of Odes 79nn 70-72, 81, 111

Analects story of Ziyou's teaching of 139

on kindred 'ambition' (zhi) $121 \mathrm{n} 8$

woodcutter Li's lack of knowledge of 133, 134

Book of Rites $\quad 30,109 n 78,130,174 \mathrm{n} 48$

Borges, Jorge Luis 5, 21-22

Büchner, Georg $5^{1}$

Buddhism

and "ornamented language" (qiyu) 24, $24 \mathrm{n} 4 \quad 34,43-44$

oxherd and the buffalo metaphor for seeking self-nature 159, 159-16on146, 160

schools of. See Chan; Tiantai

Su Shi's mocking of Kumārajīva 201, $201 n 135$

sūtras. See Diamond Sūtra; Heart Sūtra; Vimalakìrti Sūtra

upāya. See skilful means

Bush, Susan $\quad 49,83$

cai (talent)

and artistic excellence 1

the Way $(D a o)$ as the source of 1

Cai Tao $15^{-16,17}$

Campany, Robert Ford $\quad$ 130, 153 
Celan, Paul 89

Chan

lettered Chan (wenzichan) 10

meditative state. See samā dhì

monastic poetry as skilful means 10,45 , $5^{6-57}$

monastic poetry associated with Confucian values 44

patriarchs. See Hongren; Huike; Huineng; Huiyuan

this-worldly view of $\quad 7-8$

transgressions of the mouth (kouye)

$$
43-44,44 n 81
$$

wordless transmission of mind through mind (yixinchuanxin) 17-18, 18n66, 41

Cheng Yi (or Cheng Hao) 28, 28n15, 32-33

"Zhongyong jie" 3 on 26

Cheng Zhicai 176,187

Chen Tuan 191, 1910107

cicadas

hunchback cicada catcher $8 \mathrm{n} 31,38,47$

short lives of $173^{-174}$

cinnabar (dan)

and alchemist gold processing techniques 167nı1

availability in Huizhou of 170

Golden Cinnabar (jindan elixir of immortality) 169

pellet processing attempt by Bo Juyi 171 poisoning 167, 167n13

Cinnabar Field (dantian) 166-167n10, 173, 180-181

commoditisation

and exchange. See gift exchange

stigma of 104-105

and the usefulness of uselessness $\quad 20,87$

Confucianism

ideal of reclusion/"moral heroes" 125,

133-134, 136, 171

texts. See Analects; Book of Odes; Book of Rites

Craftsman Shi 71, 90, 94, 118

craftsmanship

and concentrated practice $\quad 8,8 \mathrm{nn} 29-32$, 15,27

and skilful means practice $\quad 45^{-49}$

See also skilful means yijiang ('craftsmanship of the mind') $59 n 20$

Zhuangzian. See Zhuangzian craftsmen

Danto, Arthur $\quad 3-4 \mathrm{n}_{5} \quad$ 48-49

Danzhou (Hainan) exile 32, 118, 119, 140, 193-195

cultural alienation and material deprivation experienced by Su Shi in 120

butcherbird tongue of natives of 131-132, 133

He Tao poems written by Su Shi during 119, 125-126, 130-134, 150-161, 196-197, 199

and Su Shi as a cultural force $136-137$

Su Shi's deprivation and ill health in 157 , 198

as the ultimate place of banishment $\quad 126$

Daoist alchemy

and cinnabar. See cinnabar (dan); Cinnabar Field (dantian)

embryonic respiration 180 n $_{79}$

Huangtingjing $166-167$

kan and li forces 177-179

neidan (inner) vs. waidan (outer) 167-168, 167n11, 173

and saliva. See saliva drinking

Song literati practice of inner alchemy 165-166, 167-168, 173

Su Che's practice of 168,182

Su Shi's practice of. See Daoist alchemySu Shi's practice of

triadic unity (sanyi) principle $166-167 \mathrm{n} 10$, 168-169, 168-169n22

Daoist alchemy-Su Shi's practice of

in Danzhou 193-197

Daoist diet 185

dragon-and-tiger practice $\quad 165,176-185$

in Huangzhou 168-170

in Huizhou 166,176

and immortality 21, 169-170, 195

inner alchemy preferred by 173

and Ji Kang. See Ji Kang

sun and moon practices $\quad$ 168-169, 184,

197n124

Wu Ziye (Su Shi's fellow practitioner)

177n66, 185 
Daoqian (or Canliao) 23-24, 39-40, 51, $5^{6-57}$

Diamond Sūtra 47

Ding Lingwei $188,188 \mathrm{n} 105$

disengagment

and oblivion. See oblivion

and uselessness. See sanren (useless/ disengaged man); usefulness of uselessness (wuyong zhiyong)

\section{Doctrine of the Mean}

combined with Daoist and Buddhist ideas in Su Shi's essay for Sicong $\quad 35^{-36}$ as a core Confucian classic 30

Su Shi's treatise on $\quad 30-31,36$

treatises from Early Song to Su Shi's time on 3 on 26,31

Zhongyong jie of Qisong on 3on26, 31-32

Dongfang Shuo $15,15 \mathrm{n}_{5} 8$

Douglas, Mary 105, 106

Dragon Tail baby-rock (zishi) inkstone of Zhang Jin

described 108

exchange between Su Shi and Zhang Jin related to $108-111$

Dragon Tail rock (longwei shi)

fame of 101

personification as Luo Wen 104

Phoenix Beak rock (fengzhou shi) compared with $98,101,102-103$

dreams and dreaming

Caedmon's command to create received in 5

Su Shi's dream in Snow Hall (Xuetang). See Snow Hall

Zhuangzi's dreaming that he was a butterfly 70

drinking

and artistic spontaneity $15,59,67,129$

and oblivion. See oblivion

Su Shi's "He Tao 'Zhijiu", 140, $140 n 84$

Tao Qian associated with $123,130,140$

Western cult of Dionysus 67,68

Du Fu, “Qinzhou za yong” 150-151

Egan, Ronald C. 13n52, 50, 52n114, 65, 65n33, 112n87, 164, 193n113

Fan Bailu 106-108, 106-107n69-70
Fan Zuyu 106-108, 106-107n69-70

"Zhongyong lun" 3on26

fishermen

stray fisherman's knowledge of Peach

Blossom Spring 145, 146, 154

Su Shi as a self-sufficient fisherman 191

fountain of energy 159, 193-195

Fuller, Michael A. 33, 6on24, 66, 69

Ge Hong

Baopuzi of 149n114, 151n121, 169, 17on31, 173n42, 174n49, 193

Chongxu Temple residence of $192 n 111$

and Mt Luofu site of transcendance of 122, 164, 173, 175, 187-188, 193

universalist approach to immortality 154 , 172-175

gift exchange

of inkstabs 96

See also Dragon Tail baby-rock

between Pei Du and Bo Juyi 110-111, 110n83

poems as. See poetic exchange

between the Qin and the Zhao 109, 109-110n82, 110-111

rocks exchanged by literati $105^{-106}$

and social solidarity $105^{-106}$

Su Shi's exchanges with Fan Bailu and Fan

Zuyu 106-108, 106-107n69-70

Su Shi's exchange with Wang Shen. See Qiuchi rocks

Su Shi's exchange with Zhang Jin. See Dragon Tail baby-rock

Gongsun Longzi 156

Graham, A.C. $\quad 8-9,55^{-} 56$

gushing river metaphor of Su Shi's writing process

Cai Tao's criticism of $\quad 14^{-15}$

as a myth reinforced by repetition 18

Su Shi's characterization of $\quad 12-13,40,67$

and the water-mirror metaphor $40,5^{2}$

Hanshu 96, 96n 36

Hargett, James M. 126

Hawkes, David 198n27

He Yuan 18

Heart Sūtra, Su Shi on the calligraphy of 63-64

Hegel, Georg Wilhelm Friedrich $\quad$ 87-88 
Heidegger, Martin 89

he Tao "matching Tao" poems

attributed to Tang Yanqian 123-124n21

Jiang Yan's “Tao Zhengjun tianju” 127n32

by Su Shi's admirers 161

he Tao "matching Tao" poems of Su Shi $119-120,121,125,126-127,135,161$

elements of fear and anxiety $\quad 128-129$

on death 198-199

and poetic exchange $\quad 124-125$

"Eight Poems of the East Slope" (Dongpo bashou) in the style of 122-123

and the zhuihe ('matching [an ancient poet's poems] in retrospect') genre 123-124

"He Tao 'Dongfang you yishi”, 5onı11, $155^{-156 n 134, ~ 155^{-1} 5^{6}}$

"He Tao 'Du Shanhaijing” 118, 118n103, 122nn15-16, 129n37, 175nn56-57

"He Tao 'Guiqulai xi ci”, 156-157

“He Tao 'Gui yuantianju”', 128, 128n36, 130, 13on 45

"He Tao 'Gui yuantianju liushou', 123, 123n19, 128, 128n34

"He Tao 'Huan jiuju”, 155, 155nızo

"He Tao 'Nigu jiushou", 13on40, 133, 133n52

"He Tao 'Pinshi' qishou" 139, 139n8o

“He Tao 'Quannong' liushou” 13onn38-39, 135

"He Tao 'Shen shi”, 199, 199nizo

"He Tao ‘Taohuayuan' bing yin” 148149n112, 148-152

"He Tao "Tianshe shichun huaigu ershou", $13 \ln 48$

"He Tao 'Xiasun tianshe huo'", 131n47

“He Tao 'Xing zeng ying”, 198n128

"He Tao 'Ying da xing'", $199 n 129$

"He Tao 'Yinjiu ershishou', 121nı1, 123, 123n18, 155-156n133

"He Tao 'Yong sanliang'", 143, 143n93

"He Tao 'Yuan shi Pang Deng', 138, 138n79

“He Tao 'Zashi' shiyishou” 196-198, 197n126

"He Tao 'Zeng Yang zhangshi", 136n68

"He Tao 'Zhijiu”, 140, 140n84

Su Che's preface "Zizhan he Tao Yuanming shiji yin” 119-120, 120n5 122n13, $123 n 20$
Hongren $113 n 97$

$\mathrm{Hu} \mathrm{Zi} \quad 43 n 78,101$

Huang Tingjian

"Ba Dongpo moji" 6on22

"Ba Dongpo shu" 14n55

"Ba Dongpo Shuilu-zan" 84n81

"Ba Dongpo 'Xu Yinghuang shi ti”, 6on23

"Ba Dongpo zi hou" 15n57

"Ba Zizhan 'He Tao shi”', $193 n 112$

on Su Shi's "being fond of abusing"

(haoma) $121 n 9$

on Su Shi's calligraphic style $\quad 60,84$

on Su Shi's spontaneous craftsmanship

$14-15,18$

Huangzhou exile 32

commemorated in "Eight Poems of the

East Slope" (Dongpo bashou) 122-123

Daoist practice 168-169

Su Shi's poem on the Cold Food Festival in 203

Su Shi's Xuetang residence. See Snow Hall

Huike 41

Huineng 7n23, 113n97

Huiyuan 175, 175n57

Huizhou exile

Daoist practice 166

and Mt Luofu. See Mt Luofu

Su Shi's poetic ethnography $129-130$

White Crane Peak villa in 155,165 , 187-189, 192

immortality

literary. See literary immortality

and saliva drinking 194, 194n117, 195

Su Shi's interest in longevity secrets 186-187

See also Daoist alchemy—Su Shi's practice of

Su Shi's mocking of Kumārajīva's's magic spells 201, 201n135

and Su Shi's pursuit of spontaneity in art and life 165

inkstones

individual. See Dragon Tail baby-rock; Dragon Tail rock; Phoenix Beak rock and inkstab types $\quad 96,96 n 35,97-98$

Kong Pinzhong's collection of 98-99, 101 Su Shi's collection of 86 


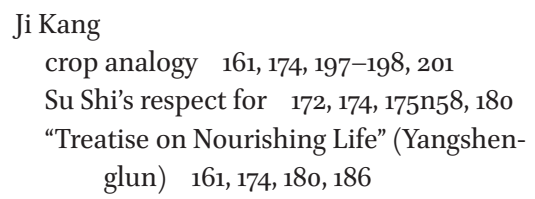

Jia Dao 42

Kafka, Franz 21

Kant, Immanuel $\quad 88,89$

Kern, Martin 8in75, 203nı

kindred spirits (zhiyin)

identification with a person through their artwork 53, 84-85

and shared 'ambition' (zhi) 121

and Su Shi's attraction to Tao Qian 125

in Su Shi's egalitarian Peach Blossom

$$
\text { Spring } 154
$$

a Li woodcutter's relationship with Su Shi 133-134

Kubin, Wolfgang 88, 90-91

kui (monster in Shanhaijing) 113, $113 n 95$

Kumārajīva 201, 201n135

Kwong, Charles Yim-tze $\quad$ 55, 146

Lackner, Michael $29 n 23$

Laozi

on climbing a terrace in spring $76 \mathrm{n} 66$

on guarding tranquility $158 \mathrm{n} 140$

read by a pupil in Su Shi's dream 166

"Returning is the movement of the Way" 180

on "returning to infancy" $158 \mathrm{n} 143,179$

on "the supreme good is like water" $13 n_{50}$

and Su Shi's resolve to become an earthly immortal 186

Laozi's (self-claimed) descendants $\quad 165$

Lenz, Jacob $5^{1}$

Li Gonglin $\quad 65,132 n_{50}$

Lin Yutang $23-24,23 n 1 \quad 204$

literary immortality

and artistic spontaneity $21,82-85,165$

and the pursuit of enlightenment $\quad 5^{2-53}$

and Su Shi's fear of decay $\quad 5^{1-52}$

Su Shi's hierarchical view of the arts 45 , 49

writing as the articulation of 24,83

Zuozhuan discussion of three kinds of 'non-decays' (buxiu) 52
Liu Xie 9, 27, 66-67

Lodge, David 203

Lu Ji, "Rhapsody on Literature" (Wenfu) 66

Lynn, Richard J. 10, 56

Lyotard, Jean-François $\quad 89,116-117$

Man of the Way archetype

moral power of 1

natural objects as exemplars of art of 1,2 , 85

perfect mirror model of spontaneity 19 , 24-25

Tao Qian as 119

Mauss, Marcel $\quad 105^{-106}$

Mencius

on ambition (zhi) $\quad 121 \mathrm{nn} 8$

Gaozi's comparison of human nature to the willow 31

human nature declared as good 32

metaphor of painting walls $47 \mathrm{n} 100$

Mi Fu

calligraphy of 84

Yan shi (History of Inkstones) 97

mirrors

metaphors. See perfect mirror metaphor;

Plato, mimesis theory; water-mirror metaphor

poetry as a mirror of the poet's true self 162

reflection of the author's face as a modern and transcultural reader by Su Shi

202-204

monastic poetry $\quad 40-44$

and Confucian values 44

monks. See Daoqian; Jia Dao; Sicong

as skilful means $10,45,56-57$

Su Shi's poem for the monk Daotong” 43

Mt Emei

San Su ci at 204

Su Shi's hometown symbolised in miniature Qiuchi rocks 118

$\mathrm{Mt} \mathrm{Lu}$

and Bo Juyi 171

and Huiyuan $\quad 175 \mathrm{n} 57$

Su Shi's transformation into 203

Mt Luofu

Ge Hong's transcendance on $122,164,173$, 175, 187-188, 193 


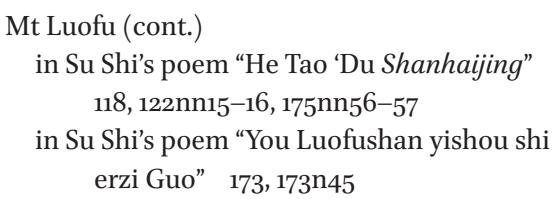

Nāgārjuna $\quad 46$

natural objects

spontaneous process of creation of 86

See also fountain of energy; gushing river metaphor of Su Shi writing process; water-mirror metaphor

Needham, Joseph and Lu Gwei-Djen 158n144, 167-169, 177n67, 182-183

Nelson, Susan $\quad$ 145-146, 149

oblivion

and the concentrated work of artistic creation $45,55,61,65^{-68}$

and liberation 61

sitting in oblivion (zuowang) $\quad 67-68,70-71$

Western tradition of 67,68

Ouyang Xiu

son Ouyang Fei 139, 139n83

on the narrow scope of vision and

vocabulary of monastic poetry

42-43

poetic exchange with Mei Yaochen 124, $124 \mathrm{n} 24$

Yan pu (Record of Inkstones) 97

Owen, Stephen $\quad$ 147, 162

ownership

Xunzi on $49^{-} 5^{\circ}$

See also attachment; commoditisation

Peach Blossom Spring

Daoist mythemes in Tao Qian's construction of 153

exclusive, utopic, and half-realistic Daoist

Heaven depiction of $145^{-148,153}$

literary motif in Quan Tang shi 147

Liu Ziji in Tao Qian's story of $152 n 124$

Mt Qiuchi as $149^{-152}$

princely estates of "weekend recluses" 147

stray fisherman's knowledge of 145,146 , 154

Su Shi's “He Tao ‘Taohuayuan' bing yin” 148-149n112, 148-150
Su Shi's metaphor for an inner realm of

bliss and 151-154

Su Shi's reenvisioning of $146-147,148-149$

Tao Qian's "Peach Blossom Spring”

("Taohuayuan ji bing shi") 120n6, 145-146, 148, 152n123

Wang Wei's "Song of Peach Blossom

Spring" ("Taoyuan xing”) 147-148

perfect mirror metaphor

and the Man of the Way archetype 19, 24-25

and the reader's recognition of the self 53 , 202-204

See also kindred spirits

Phoenix Beak rock (fengzhou shi)

authenticity of Su Shi's $\quad 98-100$

Dragon Tail rock compared with 98,101 , 102-103

"Fengzhou shiyan ming bing xu" $1005^{2}$

"Fengzhouyan ming bing xu" 100n51, $101 n 53$

“Kong Yifu Fengzhouyan ming” 98-99, 99n49

Wang Yi's discovery of $\quad 99,101$

pingdan ('the even and plain')

and the 'return into nature'/simplicity 85 , $119 n 2$

and spontaneous aesthetic appearance

$$
\text { 20, } 54-55
$$

Plato

divine inspiration/prophetic poet of 4,6

mimesis theory/mirror metaphor 4, 39, $39 n 65$

and truth 68

poetic exchange

Bo Juyi and Yuan Zhen 124

and the social solidarity 106,124

See also gift exchange

and Su Shi's matching poems 124-125

See also he Tao "matching Tao" poems of Su Shi

pottery making of the divine potter (tianjun) $3,9,67$

Pye, Michael $\quad 38-39$

$q i$ (individual disposition), and artistic excellence 1 


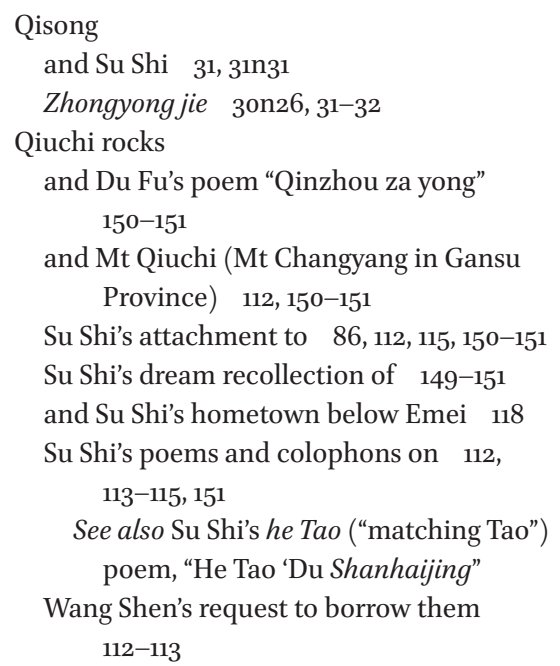

reclusion

Confucian "moral heroes" 125, 133-134, $136,138,171$

Daoist ideal of governance without interference 137

free choice/moral decision of eremitism 154

and the innate inclinations motivating

Tao's disengagement $\quad$ 137-140

and Peach Blossom Spring. See Peach Blossom Spring

road of return. See Tao Qian; Tao Qian, "Return!" (Guiqulai xi ci)

Su Shi's exile periods. See Danzhou exile; Huangzhou exile; Huizhou exile returning home. See Peach Blossom Spring; reclusion; road of return; Tao Qian; Tao Qian, "Return!" (Guiqulai xi ci) return into nature/simplicity

and the Chinese philosophy of metamorphosis $153^{-154}$

and pingdan ('the even and plain') 85, $119 n 2$

by Su Shi 19, 120, 136, 163

road of return

innermost mind/one's authentic state identified with $155^{-15^{6}}$

Qiuchi rocks as symbols of 118

Robinet, Isabelle $\quad$ 153, 168-169n22, 179 rocks

commoditisation of 105,112

as eloquent speakers guiding the path towards illumination 91

eloquent stones $\quad 86-118$

as gifts $105^{-106}$

individual. See Dragon Tail baby-rock;

Dragon Tail rock; Phoenix Beak rock;

Qiuchi rocks

inkstones. See inkstones

in literati economics 104-119

Su Shi's childhood fascination with 117

as symbols of their possessor's moral

stature 91

ugly and useless as signs of refinement

94-96

saliva drinking

and cosmic balance $169,185 \mathrm{n} 92$

and immortality 194, 194n117, 195

as precious nectar in physiological alchemy 182-185

'in water the tiger is born' practice 181

samādhī (ding; 'meditation' or 'concentration')

and hui (intellect or 'wisdom'prajña) 36

youxi sanmei (play in samādhi) $\quad 7-8$

sanren (useless/disengaged man) 71-72, 71n54, 91-92, 118

Schiller, Johann C.F. von, aesthetic freedom of 7-8

Scholar Anqi

Calamus Gully domain of $152 \mathrm{n} 124$

esoteric truth of $154,160,161$

Su Shi's poem "Anqisheng" 187ng8

shensi ('divinely inspired thinking') 3, 67

Shiji (Records of the Grand Historian) 58-59, 79n72, 91n23, 109n8o, 110n82, 1910109

Shi Cangshu

cursive-style calligraphy practice of 59

Drunken Ink Studio (Zuimotang) of 58,67

"Shi Cangshu Zuimo tang" written by Su

Shi for $57-58,58 \mathrm{nn} 16,18$

Shishuo xinyu, on superfluous things

Sicong (zhàngwu) $87 \mathrm{n}_{5} \quad 91$

biographical details $34,37,40$ 
Sicong (cont.)

Su Shi's "Seeing off Sicong" essay for $33-38,40,45,57$

skilful means (upāya;fangbian)

discarding of 61

in Mahāyāna Buddhism 10, 38

and poetry $10,45,52,56-57$

practice of bodhisattvas 45-49

Snow Hall (Xuetang)

referred to in a poem for Zhang Jin 109

Su Shi's building of 68,69

Xuetang ji ("A Record of Snow Hall") 69-82

Xuetang wen Pan Binlao 69n5o, 71n53

spontaneity

and aestheticised 'nature' $\quad 88-89$

balanced with mnemonic practice. See pingdan

of bird song 88

and concentrated practice $8,8 \mathrm{nn} 29-32,31$

of the Creator's craft $14-15$

of the divine potter (tianjun) $3,9,67$

impossibility of 202

of the Man of the Way. See Man of the Way archetype

and modern art 89

of natural objects 86

See also fountain of energy; gushing river metaphor of Su Shi writing process; water-mirror metaphor

of Su Shi's creative process as an illusion 18

returning to the original 162

Tao Qian's "finger-less zither" 50

spontaneity of artists

and the absence of self-consciousness 15

See also drinking

aesthetic and moral power of a Man of the Way 1

and concentrated and mindful practice 3-4

and mind-craft (yizao) $\quad 58,59$

and Su Shi's pursuit of immortality 21, $82-85,165$

and unattainability $31,52,68,119,162,202$

Sturman, Peter Charles 84, 97

Su Che (Su Shi's brother) 11, 61, 32

"Fengzhou shiyan ming (bing xu)", 10on52 inner alchemy practice of 168

Leizhou exile 140

"Qin Mugong mu" matching poem 142, 142ngo

and San Su ci 204

on Su Shi's calligraphy 57

on Su Shi's emulation of Tao Qian 119-120

"Zizhan he Tao Yuanming shiji yin" $120 n_{5}$ 122n13, $123 n 20$

Su Dai (Su Shi's second son) 139, 139n83

Su Guo (Su Shi's third son) 123, 130, 173n 45

Su Shi

calligraphy of $57-60,83-84$

on Daoqian's poetry $23-24,39-40,51$, 56-57

letter to Wang Dingguo $\quad$ 186-187

life of. See Su Shi, biographical details

reception history of 14, 18, 203

on the unity of the three arts $26,26 \mathrm{ng}$

Su Shi, biographical details $\quad 1,1 n 3$

death of 21, 198, 201

exile periods. See Danzhou exile; Huangzhou exile; Huizhou exile

gentry clan family of 11

as Magistrate of Yangzhou $107,123,150-151$

as Magistrate of Yingzhou $139 n 83,149-150$

official post in Fengxiang 141-142, 168

sons. See Su Dai, Su Guo

style name, Dongpo $\quad 1,69$

Su Shi essays

"Baihe xinju shangliangwen" 188n102, 188-192

“Ba Ji Shuye 'Yangshenglun' hou” 174, 174n 51

"Baohui Tang ji" 50niog

"Cai riyuehua zan" 169n25

"Da Qin Taixu qishou" 168nn2o,21

"Han Yu lun" 31, 3in29

"Ji Ziyou sanfa" 186n93

“Kong Yifu Fengzhouyan ming” 98-99, $99 n 49$

"Longhu qiangong shou" $176-179,176$ n64, $180-182,183^{-184}, 185^{-186}$

"Mobao Tang ji" $50 n 110$

"Momiao Tung ji" 51, 51n113

“Nan'an-jun Changle-yuan xin zuo jingzang ming" 48, 48n102

"Ping Han Liu shi" 55 n6 
"Qianzhou Chongqing Chanyuan xin jingzang ji” 46-47, 47n101, 61-62, $62 n 27$

"Riyu" 33, 33nn 44-45

"Shu huabi yishi" $112 n 92$

"Shu Li Boshi Shanzhuangtu hou" 65 n34

"Shu Wu Daozi hua hou" 65n31

"Song Qiantang seng Sicong gui Gushan xu" $33-38,40,45,57$

"Tianshiyan ming" 117, 117 n102

"Ti Bizhen-tu" 52n114

"Wanshi-jun Luo Wen Zhuan" 104

"Wen Yuke hua Yundang gu yanzhu ji" 6o-61, 6in25, 65n35

"Xiaozhuan Bore Xinjing zan" 63-64, $64 n 29$

"Xu yangshenglun" 186

"Yangshengjue" 182n84

"Yang Xiong lun" 31n28

"Yu Cheng Quanfu shiershou" $1304_{2}$

"Yu Cheng Zhengfu qishiyishou" 176nn $59,62-63$

"Yu Cheng Zhengfu sanshou" 176n62

"Yu Erlang zhi yishou" 54n5

"Yu Liu Yiweng shijun shu" 166n7

"Yu Teng Dadao liushibashou" 168n20

"Yu Wang Dingguo sishiyishou" 169n28, 17on30, 187n97

"Yu Wang Xiang wushou" 166nn7-8

"Zhongyong lun" 30-31,

"Zhongmiao tang ji" 166n6

Su Shi poems

"Anqisheng" 187ng8

"Beijiu duxing, bianzhi Ziyun, Wei, Hui, Xianjue sili zhi she, sanshou" 136 n69

“Chubie Ziyou" 168nı

"Ciyun Fan Chunfu 'hanxingyan' “yueshi fenglin ping shi" $107 \mathrm{n} 72,108 \mathrm{n} 74$

"Ciyun Wu Chuanzheng 'Kumuge', 26n9

"Ciyun Zhengfu tongyou Baishuishan" 152n22, 192n111

"Ciyun Ziyou lunshu" 57n13, 57

"Cui Wenxue Jia xiewen jianguo xiaoran you chucheng zhi zi [...]", $17 n 64$

"Da Jingshan Lin zhanglao" 201, $201 n 134$

"Dongpo bashou" 122-123

"Du daozang" 168nı6

"Guo Dayulin" 170-171, 171n35
“Guo Wen Jue Xiangong fang” 109n79

"Guo Xiangzheng jia zui hua zhushi bishang [...]", 108n76

he Tao "matching Tao" poems. See he Tao "matching Tao" poems of Su Shi

"Hou Chibi fu" 195-196, 196n123

"Huangzhou yu ershou" 203n3

"Huzhong Jiuhua shi" 105 n66

"Liubie Jian daoshi Gongchen" $170{ }^{34}$

"Liu ti Xianduguan" 166-167nı

"Longweiyan ge bingyin" 102-103, 102n58

"Mingri Nanchan heshi budao" 200, 200n133

"Pu suocang Qiuchi-shi xidaizhibao ye [...]", 112ngo

"Qian Chibi fu" 195-196, 196n122

"Qianju" 188n101

"Shi Cangshu Zuimo tang" 57-58, 58n16,18

"Shi jin yi 'yeushi yan ping' xian Zigong Zhongshu gong [...]", 106n69, 107n73

"Shi yu yi shi yi hua Jinqing nanzhi [...]", 112n9o, 113, 113n93

"Shizhi" 17on32

"Shuangshi" 112n89, $151 \mathrm{n} 118$

"Shu liu Zihou 'Niufu' hou" 130n41

"Shu Yanling Wang Zhubu suo hua Zhezhi ershou" 26ng

"Song Canliao Shi" 39n24, 45n86

"Tianqingguan ruquan fu" 193, 193n114, 196

"Ti Xilin bi" 203n2

"Wang Jinqing shishi yu du haishi [...]", $112 n 91$

"Xinnian wushou" 187 nioo

"Yeziguan" 13onn38-39

"Yi xuexiao gongju zhuang" 28n16, 29nn20,25

"Yong guaishi" 92-94

"Yong guo yun, Dongzhi yu zhusheng yinjiu" $136 \mathrm{n} 69$

"You Luofushan yishou shi erzi Guo" 173, $173 n 45$

"Zai Pengcheng ri yu Dingguo wei Jiuri Huangzhou zhihui [...]", 169n27

"Zeng Li Si Yanwei xiucai" 136n69

"Zeng shiseng Daotong" 4on66

"Zhang Jin Jizhong you Longwei zishi yan yi tongjian yi zhi" $\quad$ 108-110, 108n77 
Su Shi poems (cont.)

"Zhang zuoshi songyan fanjian, nai he qishi, zu yi jian gui zhi" $111 n 86$

"Zheju sanshi sanshou" 200, 200n133

"Zhenyijiu ge" 185ngo

"Zhuoliao you miaoli fu" $67 n 43$

Su Xun (Su Shi's father) 11, 32, 117, 204

Su Xun (Su Che's third son) $122 n 14$

Su Yijian 97

sudden (dun) and gradual (jian) approaches to enlightenment $5^{6}$

and Su Shi's notion of apprenticeship 56-57

and Tiantai's Threefold Truth theory 46

Sun Simiao 182

superfluous things (zhàngwu)

and moral concerns $\quad 20,91$

in the Shishuo xinyu $\quad 87 \mathrm{n}_{5} \quad 91$

and Su Shi's rocks as collectors' items 87

Śūramgama Sūtra (Lengyan jing)

combined with Daoist and Confucian ideas

in Su Shi's essay for Sicong $35^{-36}, 37$

six senses $\quad 93 n 29$

"three learnings that have no omission" $35 \mathrm{n} 50$

and "returning [to the root] upon hearing

[the truth]", $37 \mathrm{n} 55$

Swartz, Wendy 2n4 9,125

Tao Qian

biographical details $\quad 2 \mathrm{n} 2 \quad$ 127n33, 138-139

poem "Gan shibuyu fu" 137, 137n75

poem “Guiyuantianju" 123, 128, 128n35, 130n45

poem "Nigu jiushou" 132, 132n51

poem "Taohuayuan ji bing shi" $120 n 6$

145-146, 148, 152n123

poem "Quannong” 135

poem "Guiqulai xi ci" 120-121, 156n138, 157

poem "Zhijiu" 141

poem "Yong Sanliang" 142n92

poem "Xing ying Shen" $175 \mathrm{n} 54,198,198 \mathrm{n} 27$

reception history of $121,125,146,146,161$

Shu Shi's role in canonisation of 119, 125, 161-163

string-less zither of 50

and Su Shi's "matching Tao" poems. See he

Tao "matching Tao" poems of Su Shi
Su Shi's paradoxical emulation of $\quad 2,162-163$

Yuanming as a name of $2 \mathrm{n} 4$

'Three Worthies' (sanliang)

Su Shi's citing of 143-144, 145

Su Shi's commentary on 141-142

Tao Qian on 142

Zhuozhuan's description of sacrifice of 141

Tiantai School

Threefold Truth (sandi) theory 19, 45-46, 68,200

Zhiyi's founding of 46

Tian Xiaofei 125

Tomlonovic, Kathleen M. 126

triadic unity. See under Daoist alchemy

usefulness of uselessness (wuyong zhiyong)

and being a useless man. See sanren

and dispensability 91

and the moral superiority of the grotesque garden rock ("Yong guaishi") 92-96 of superfluous things (zhàngwu) 20, 87, 91 in the Zhuangzi 20, 71, 72, 90, 157

Vervoorn, Aat $\quad 91-92,138,154$

Vimalakìrti Sūtra (Weimojie suoshuojing)

on greed for emptiness 45

insightful goddess in $47-48$

and Su Shi's poem to Wang Shen 114, 115

Vimalakīti and the sylphs story in $114 n 99$

Waley, Arthur $\quad 177 \mathrm{n} 67$

Wang Angshi $\quad$ 28-29, 52, 193

Wang Dingguo 169-170, 169n27

Su Shi's letter to $186-187$

Wang Shen 112-115

Wang Wengao $58 \mathrm{n} 16$

Wang Xizhi (aka Yishao) 58n17, 6o, 102n61, 188n104, 189

Wang Yinglin $77 n 68$

water-mirror metaphor

in Confucian texts 39

Daoqian's style described by Su Shi $23-24$, $39-40,51,56$

and the gushing river metaphor $40,5^{2}$

and spontaneous artistic creation $5^{0}$, $56-57,159$

Su Shi's advice to Sicong $\quad 34,3^{8-39,40,57}$ 


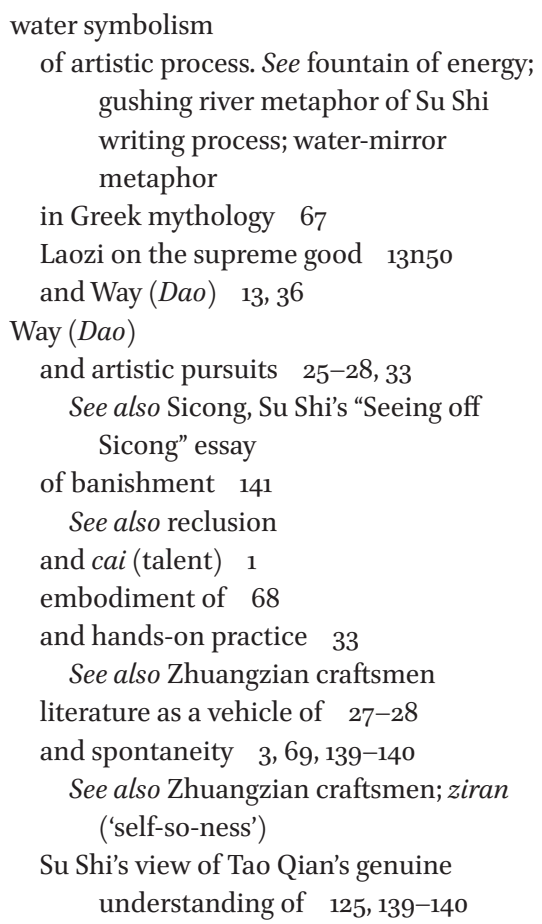

Yuan Ke 113n95

Yuan Xingpei 127n33, 135n61

Yuan Zhen 124

Zhang Dun 135-136, 136n65, 193, $193 n 112$

Zhang Jin

exchange of objects with Su Shi 108, 110-111

"Zhang Jin Jizhong you Longwei zishi yan yi tongjian yi zhi” 108-110, 108n77

zhàngwu. See superfluous things

Zhang Zhi 58nn15-17, $59^{8}$

Zhao Yi 17-18

zhiyin. See kindred spirits

Zhong You 58n15, 59, 102n61

Zhou Dunyi 27-28

Zhouyi cantongqi 178

Zhu Bian 135

Zhu Xi

The Ode "Kaopan" understood by $79 n 71$

on 'Learning of the Way' (daoxue) 33

on pingdan 54

Su Shi criticised by $16,121 n 10$

Zhuangzi

dreaming that he was a butterfly 70

inspiration on China's eremitism 91-92

kun fish from 92, 99n48

peng bird from 92, 99, 113, 113n94

on the usefulness of uselessness $20,71,72$, 90

on wordless truth 9

Zhuangzian craftsmen

Cook Ding 8, 8n29, 72

Craftsman Shi 71, 90, 94, 118

hook maker 47,47 ng 8

hunchback cicada catcher 8 n31, 38, 47

and the Mencian metaphor of painting walls $47 \mathrm{n} 100$

pig fatness expert $\quad 47,47 \mathrm{n} 99$

rapids diver $8-9 n 32$

spontaneity of $8-9,27,55^{-56}$

and Su Shi's notion of apprenticeship 56 , 84

wheelwright Bian 8n3o, 15

Zhuangzian Daoism

and affirmation of the phenomenal world 8

and Su Shi $\quad 8,164,164 n 2 \quad$ 198n27 
Zhuangzi-chapters

"Xiaoyaoyou" chapter one 73n59, 9on17, $92 \mathrm{n} 27,99 n 48,113 n 94,156 \mathrm{n} 136$

"Qiwulun" chapter two 14n53, 70nn51-52

"Yanshengzhu" chapter three 8n29

"Renjianshi" chapter four 71n54, 77n69, $90 \mathrm{n} 16$

"Dazongshi" chapter six 151 ni20

"Yingdiwang" chapter seven 158n142

"Quqie" chapter ten 74n61

"Zaiyou" chapter eleven 74n61, 158n141

"Tiandi" chapter twelve $77 \mathrm{n} 67$

"Tiandao" chapter thirteen 8nzo

"Tianyun" chapter fourteen $84 \mathrm{n} 82$

"Dasheng" chapter nineteen $\quad 8-9 n n 3^{1-32}$
"Zhibeiyou" chapter twenty-two $47 n 98$

"Waiwu" chapter twenty-six 34n34

"Lie Yukou" chapter thirty-two $75 \mathrm{n} 65$ ziran ('self-so-ness')

premodern adjectival and adverbial meaning of 3

Su Shi's creative process described by Huang Tingjian as $\quad 14-15$

Su Shi's creative process described by Zhao Yi as $17-18$

Zhuangzian craftsman as 9

Zuozhuan

sacrifice of the 'Three Worthies' (sanliang) 141

three kinds of 'non-decays' (buxiu) in $5^{2}$ 